Uniwersytet Przyrodniczy w Lublinie

\title{
Wybrane zagadnienia produkcji zwierzęcej
}

Tom 1

Środowisko - Roślina - Zwierzę - Produkt 
Wybrane zagadnienia

produkcji zwierzęcej

Tom 1 
Środowisko - Roślina - Zwierzę - Produkt 


\section{Wybrane zagadnienia produkcji zwierzęcej}

Tom 1

pod redakcją

Witolda Chabuza

Bożeny Nowakowicz-Dębek

Lublin 2020 


\title{
Recenzenci
}

prof. dr hab. inż. Ewa Czerniawska-Piątkowska

dr hab. Aldona Kawęcka

\author{
Opracowanie redakcyjne \\ Renata Zelik \\ Magdalena Marcewicz
}

Projekt okładki

Jacek Pałyszka

\section{(C) $(1) \Theta \Theta$}

Ten utwór jest dostępny na licencji Creative Commons Uznanie autorstwa Użycie niekomercyjne - Bez utworów zależnych 4.0 Międzynarodowe.

\section{ISBN 978-83-7259-330-6 on-line}

DOI: $10.24326 /$ mon.2020.9

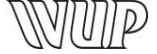 \\ Wydawnictwo Uniwersytetu Przyrodniczego w Lublinie \\ ul. Akademicka 15, 20-950 Lublin \\ www.wydawnictwo.up.lublin.pl \\ 11,5 ark. wyd.
}




\section{Spis treści}

Piotr Dziechciarz, Krzysztof Olszewski

Nosemoza pszczoły miodnej - charakterystyka i czynniki wpływające na poziom inwazji

Honey bee nosemosis - characteristic and factors influencing on the infestation level

Martyna Frątczak, Patrycja Małysz, Marta Dybczyńska, Elżbieta Wnuk-Pawlak

Powstanie i hodowla krajowa rasy konik polski

Genesis and domestic breeding of polish horses

Aleksandra Garbiec, Mirosław Karpiński, Justyna Wojtaś

Określanie poziomu stresu u zwierząt towarzyszących na podstawie poziomu kortyzolu

w różnych materiałach biologicznych

Determining the level of stress in companion animals on the basis of cortisol levels

in various biological materials

Wiktoria Janicka, Wanda Krupa

Optymalizacja warunków utrzymania koni w kontekście możliwości prezentowania naturalnych zachowań

Optimisation of the horse keeping conditions in the context of the possibility

to present natural behaviour

Pawel Jurczak, Anna Polz, Zuzanna Całyniuk, Patrycja Cieplińska, Marcin Kiewlak,

Agnieszka Serek, Ewelina Cholewińska, Katarzyna Ognik

Badanie wpływu barbituranów jako substancji wykorzystywanych w eutanazji na stopień

indukcji stresu oksydacyjnego $\mathrm{w}$ organizmie psa ...

Research on the effect of barbituranes as substances used in euthanasia on the degree of infunction

of oxidative stress in the dog's body

Paulina Kamińska, Jarosław Kamieniak, Malgorzata Goleman

Wpływ wybranych czynników na wynik zmodyfikowanego egzaminu psa towarzyszącego

I stopnia

The influence of selected factors on the result of the modified Obedience Test I level

Anastasia Korenitska, Piotr Czyżowski, Wanda Krupa

Zachowania stereotypowe wilków szarych utrzymywanych w warunkach

Ogrodu Zoologicznego we Wrocławiu

Stereotypic behaviors in gray wolves living in the ZOO Wrocław

Aneta Krawiec, Katarzyna Zdrzałek, Patrycja Spędzia, Aleksandra Szczepanik

Pawel Żólkiewski, Witold Chabuz, Jan Zdulski

Adaptacja zwierząt gospodarskich do lokalnych warunków środowiskowych na przykładzie bydła

Adaptation of farm animals to local environmental conditions on example of cattle

Aneta Krawiec, Katarzyna Zdrzalek, Patrycja Spędzia, Aleksandra Szczepanik,

Pawel Żólkiewski, Witold Chabuz, Anastasiia Pishchik

Wpływ czynników środowiskowych na występowanie zapalenia wymienia

The influence of environmental factors on the occurrence of mastitis

Aneta Krawiec, Piotr Domaradzki, Piotr Skalecki, Pawel Żólkiewski, Piotr Stanek,

Mariusz Florek, Michal Prasow, Marek Kowalczyk, Agnieszka Kaliniak-Dziura,

Edyta Kowalczuk-Vasilev, Katarzyna Zdrzalek

Wpływ dodatku siemienia lnianego w dawkach pokarmowych cieląt odsadków

rasy limousine na wartość rzeźną i skład chemiczny mięsa

Influence of linseed in Limousin calves diets on slaughter value and meat quality 
Marlena Księżarczyk, Paulina Leśniak, Marcin Bartlomiej Arciszewski,

Jose Luis Valverde Piedra

Wykorzystanie metody kometkowej do identyfikacji uszkodzeń struktury DNA erytrocytów

gęsi po ekspozycji na $\mathrm{CdCl}_{2}$ in vitro

The use of comet assay method for the detection of DNA-damage in geese erytrocytes

after exposure to $\mathrm{CdCl} 2$ in vitro

Paulina Lipińska, Małgorzata Goleman

Pożądane cechy u owczarków belgijskich w zależności od linii hodowlanej

Desirable traits in Belgian shepherd depending of the breeding line

Paulina Lipińska, Jarosław Kamieniak, Małgorzata Goleman

Wpływ wybranych czynników na częstość występowania i skuteczność eliminacji

zachowań niepożądanych u psów

The influence of selected factors on the frequency of the manifestation and the effectiveness

of elimination undesired behaviors in dogs

Patrycja Małysz, Martyna Fratczak, Elżbieta Wnuk-Pawlak

Wrzody jako choroba cywilizacyjna koni

Gastric ulcers as a civilization disease among the horses

Elżbieta Olszewska, Zbigniew Bełkot, Leszek Guz

Nowotwory komórek barwnikowych u bojowników syjamskich (Betta splendens)

Neoplasia of melanophores in Siamese fighting (Betta splendens)

Adrian Pluta, Kinga Smater, Damian Spustek, Kamil Drabik, Iwona Rozempolska-Rucińska

Justyna, Batkowska

Struktura społeczna w stadzie kur nieśnych i jej wpływ na behawior i fizjologię ptaków

Social structure in the laying hen stock and its influence on birds' behaviour and physiology

Magdalena Sobuś, Karolina Burczyn, Aleksandra Drzal, Paulina Iwase,

Agata Klisiewicz

Jakościowa ocena kondycji koni z wykorzystaniem współczynnika BCS

Quantitative assessment of equine silhouette using Body Condition Score coefficient

Magdalena Sobuś, Nikola Adamczyk, Magdalena Tarach

Rzekomy rak kopyta - etiologia, leczenie. Opis przypadku

Equine hoof canker - etiology and treatment. A case report

Kostiantyn Vasiukov, Adrian Pluta, Alina Woronowa, Karolina Wengerska,

Kamil Drabik, Justyna Batkowska

Wybrane choroby pasożytnicze drobiu

Selected poultry parasitic diseases

Anna Wiśniewska, Katarzyna Strzelec, Martyna Frątczak

Porównanie zmian w częstości pracy serca koni użytkowanych przez jednego

i wielu jeźdźców 166

Comparison of changes in heart rate of horses exploited by one and many riders 
Piotr Dziechciarz ${ }^{1,2}$, Krzysztof Olszewski $^{1}$

\title{
Nosemoza pszczoły miodnej - charakterystyka i czynniki wpływające na poziom inwazji
}

\author{
Honey bee nosemosis - characteristic and factors influencing on the infestation level
}

Współczesne pszczelarstwo stanowi ważną gałąź działalności rolniczej, zwłaszcza w krajach rozwiniętych, gdzie w strukturze użytków rolnych znaczny udział mają monokulturowe uprawy roślin entomofilnych. Szacuje się, że w skali globu ze 124 głównych gatunków roślin uprawnych 70\% jest zależnych od zapylania przez owady, przede wszystkim przez pszczoły miodne [Settele i in. 2009]. $\mathrm{Na}$ efektywność zapylania tych upraw wpływają liczba i kondycja rodzin pszczelich. Współcześnie istotnie zyskują na znaczeniu badania naukowe, w których pszczoła miodna jest traktowania jako zwierzę modelowe i specjalne [Łoś $\mathrm{i}$ in. 2019]. Wynika to głównie z poznania genomu tych owadów oraz odkrycia analogii między mechanizmami sterującymi procesami biochemicznymi i nerwowymi u pszczół do tych obserwowanych u ssaków, w tym u ludzi [Lockett i in. 2010, Trujillo i in. 2013].

Współcześnie do największych problemów pszczelarstwa zaliczane są choroby pszczół. Jedną z nich jest powszechnie występująca nosemoza, wywoływana przez pasożytnicze grzyby Nosema spp. W wyniku wysokiej zakaźności powoduje ona istotne straty bezpośrednie poprzez znaczne obniżenie produkcyjności rodzin pszczelich, a także straty pośrednie - będące następstwem wyraźnego spadku potencjału rodzin pszczelich jako źródła zapylaczy. Uważa się, że nosemoza jest jedną z przyczyn zespołu masowego ginięcia rodzin pszczelich (CCD), który prowadzi do strat rodzin pszczelich na całym globie [Kevan i in. 2005, Ptaszyńska i in. 2012]. Zarażeniu ulegają wszystkie kasty pszczół [Chen i in. 2009]. Przyczyną nosemozy są dwa gatunki mikrosporydiów - Nosema apis i Nosema ceranae [Ptaszyńska i Mułenko 2013]. Grzyby Nosema spp. uszkadzają nabłonek jelita środkowego, a poprzez to upośledzają trawienie i wchłanianie substancji odżywczych, co w konsekwencji ogranicza efektywność pracy pszczół i skraca ich życie [Chen i in. 2009, Gisder i in. 2010]. Głównym miejscem namnażania i pasożytowania Nosema spp. jest tkanka jelita środkowego [de Graaf i Jacobs 1991]. Ostatnie badania jednak wykazują, że oba gatunki tego grzyba nie są

\footnotetext{
${ }^{1}$ Uniwersytet Przyrodniczy w Lublinie, Wydział Nauk o Zwierzętach i Biogospodarki, Instytut Biologicznych Podstaw Produkcji Zwierzęcej

2 piotr.dziechciarz@up.lublin.pl
} 
specyficzne tkankowo. Poza nabłonkiem jelita środkowego ich zarodniki można znaleźć również w cewkach Malpighiego, gruczołach gardzielowych, śliniankach i zbiorniczku jadowym. Formy przetrwałe - spory obecne w tych strukturach - mogą zakłócać ich funkcje związane m.in. z produkcją mleczka pszczelego, miodu, wosku czy pierzgi pszczelej [Copley i Jabaji 2012].

\section{Zakażenie i rozwój choroby}

Zakażenie pszczół następuje poprzez spożycie pokarmu zanieczyszczonego sporami (zarodnikami), w tym zlizywanie kału chorych pszczół zawierającego niecałkowicie przetrawione i wchłonięte w jelicie środkowym węglowodany [Webster i in. 2004, Chen i in. 2008]. Rozprzestrzenianiu się pasożyta sprzyja typowa dla owadów społecznych trofolaksja, czyli dzielenie się posiadanym w wolu pokarmem z innymi osobnikami [Higes $\mathrm{i}$ in. 2010]. Optymalna dla wzrostu zarodników temperatura w jelitach pszczelich wynosi $30-34^{\circ} \mathrm{C}$ [Michalczyk i Sokół 2014] i jest zbliżona do temperatury wychowu czerwiu [Jones i Oldroyd 2006]. Zarodniki pozostają aktywne przez ponad siedem miesięcy [Michalczyk i Sokół 2014]. Rozwój nosemozy wywołanej przez N. apis jest sezonowy. Pik inwazji tej choroby obserwuje się wiosną, gdy następuje najbardziej wzmożony rozwój rodzin pszczelich, czyli intensywny wychów czerwiu, a w efekcie szybkie zwiększanie się liczby robotnic w rodzinie [Fries i in. 2013]. Latem poziom infekcji stabilizuje się i jest niski, natomiast ponowny intensywny rozwój choroby następuje jesienią [Gajda 2010]. N. ceranae pierwotnie została zidentyfikowana u pszczół wschodnich (Apis cerana). Naturalnym rejonem występowania tego gatunku jest południowo-wschodnia Azja [Fries i in. 1996]. Ostatnie badania wskazują, że współcześnie infekcje $N$. ceranae u pszczół miodnych są jednak bardziej rozpowszechnione niż infekcje spowodowane przez $N$. apis, co powodowane jest większą zjadliwością pierwszego patogenu [Paxton i in. 2007, Forsgren i Fries 2010]. Pszczoły zakażone przez $N$. ceranae szybko umierają, zwykle poza gniazdem, bez objawów klinicznych [Chen $i$ in. 2009]. Taka sytuacja może być spowodowana wirusami towarzyszącymi $N$. ceranae [Forsgren i Fries 2010]. Co więcej, $N$. ceranae jest obcy dla pszczół A. mellifera, przez co ich odporność na $N$. ceranae nie jest jeszcze wykształcona na poziomie adekwatnym do odporności na $N$. apis.

\section{Wpływ temperatury powietrza na rozwój nosemozy}

W czasie ciepłych letnich miesięcy pszczoły miodne wychowują czerw, zbierają pokarm oraz rozbudowują gniazdo, zwiększając siłę rodziny. Zimą w warunkach klimatu umiarkowanego pszczoły pozostają w gnieździe, gdzie czekają na powrót wyższych temperatur, niezbędnych do wznowienia intensywnego wychowu czerwiu [Winston 1991]. Czerwienie matki pszczelej wymaga stałej temperatury 
$34,5^{\circ} \mathrm{C}$, która może być osiągnięta dzięki energii cieplnej dostarczonej z zewnątrz lub wytworzonej w termogenezie drżeniowej jako konsekwencji zamiany w mięśniach tułowiowych cukrów prostych na energię cieplną. Źródłem węglowodanów jest miód. Ze względu na niekorzystne warunki wychów czerwiu zimą jest wstrzymany lub istotnie ograniczony [Winston 1991]. Tak ważny dla pszczół czynnik, jakim jest temperatura, wpływa również na ich pasożyty, w tym Nosema spp. Badania wskazują na ujemną korelację między wzrostem średniej dziennej temperatury wiosną a intensywnością porażenia pszczół przez Nosema spp. [Chen i in. 2012, Retschnig i in. 2017]. Jest to efekt braku możliwości lotów robotnic poniżej temperatury $10^{\circ} \mathrm{C}$, a co za tym idzie oddawania kału [Retschnig i in. 2017]. Powyższe obserwacje mogą pozwalać na przewidywanie zmian $\mathrm{w}$ dynamice zakażenia na podstawie średniej temperatury powietrza [Chen i in. 2012]. Warto zaznaczyć, że spory $N$. Cerance w temp. $-18^{\circ} \mathrm{C}$ tracą żywotność po jednym tygodniu i są bardziej wrażliwe na niskie temperatury niż spory N. apis [Fries 2010]. Takie zależności mogą tłumaczyć tendencję do powszechniejszego występowania $N$. apis w krajach o surowszym klimacie niż $N$. ceranae, który częściej występuje na obszarach subtropikalnych [Fries 2010].

\section{pH środowiska jako czynnik indukujący porażenie Nosema spp.}

Jednym z kluczowych czynników wpływających na rozwój nosemozy może być odczyn środowiska [Czekońska 2007, Ptaszyńska i in. 2013]. Szybszy rozwój infekcji oraz zwiększona śmiertelność zainfekowanych robotnic została zauważona po ekspozycji na $\mathrm{CO}_{2}$ inokulatu zawierającego spory Nosema spp. [Czekońska 2007]. Dwutlenek węgla rozpuszczony w wodzie, tworząc kwas węglowy, obniża pH roztworu, co sprzyja rozwojowi spor pasożyta. Podobne wyniki uzyskali Ptaszyńska i in. [2013] w badaniach zasadności dodawania etanolu do syropu cukrowego podawanego pszczołom. W mniemaniu niektórych pszczelarzy takie postępowanie ma chronić pszczoły przed zakażeniem Nosema spp. Okazało się, że podobnie jak ma to miejsce u zwierząt kręgowych [Martins i in. 1977], także u pszczół metabolizm etanolu prowadzi do zakwaszenia środowiska przewodu pokarmowego, co stwarza korzystne warunki dla rozwoju nosemozy [Ptaszyńska $\mathrm{i}$ in. 2013]. Zakwaszenie przewodu pokarmowego jest prawdopodobnym powodem spadku lub utraty możliwości regeneracyjnych krypt nabłonka jelit [Howis i in. 2010]. Ma to ogromne znaczenie w rozwoju i przebiegu nosemozy, gdyż jest to choroba niszczącą podstawowe struktury nabłonka jelit pszczół, przez co redukuje i/lub uniemożliwia wchłanianie składników pokarmowych, a w konsekwencji przyczynia się do osłabienia pszczół i ich przedwczesnej śmierci [Ptaszyńska i in. 2013]. 


\section{Wpływ pestycydów na porażenie pszczól miodnych przez Nosema spp.}

Pszczoła miodna jest narażona na oddziaływanie wielu szkodliwych substancji, m.in. pestycydów [Roman 2003]. Skala problemu jest duża, zwłaszcza w krajach rozwiniętych, co wynika z silnej chemizacji w rolnictwie [Godfray i in. 2015]. $\mathrm{Na}$ pszczoły szkodliwie oddziałują m.in. powszechnie stosowane w ochronie roślin neonikotynoidy. Wśród konsekwencji stosowania tych związków wymienia się problemy z koordynacją ruchową i drgawki [Suchail i in. 2001], a dalej brak aktywności oraz reakcji na bodźce zewnętrzne, co składa się na toksyczność przewlekłą insektycydów [Suchail i in. 2001, Mędrzycki in. 2013]. Okazuje się, że ekspozycja pszczół na neonikotynoidy, poza oddziaływaniem neurotoksycznym, osłabia także odporność immunologiczną tych owadów, co w powiązaniu z osłabieniem organizmu wywołanym toksycznością pestycydów ułatwia przenikanie do organizmu i rozwój grzybów Nosema spp. [Alaux i in. 2010]. Szczególnie niepokojące wydają się wyniki badań Pettisa i in. [2012], którzy wykazali zwiększone porażenie przez Nosema spp. młodych pszczół pozyskanych z kolonii traktowanych subletalnymi dawkami imidaklopridu. Niewykluczone, że taki trudny do zdiagnozowania w warunkach polowych synergizm działania pasożyta i pestycydu powodujący znaczne zmniejszenie liczby pszczół, a w konsekwencji osłabienie rodzin, może być jedną z głównych przyczyn zespołu masowego ginięcia rodzin pszczelich $-\mathrm{CCD}$.

\section{Zwalczanie warrozy a nosemoza}

W Polsce podstawową substancją czynną preparatów wykorzystywanych do zwalczania pasożytów $V$. destructor jest amitraz (trzeciorzędowa zasada aminowa, pochodna formamidyn). W rodzinach pszczelich leczonych preparatami na bazie amitrazu stwierdzono istotnie większy stopień zakażenia pszczół przez nosemozę niż w rodzinach nieleczonych tymi środkami. Na tej podstawie O1szewski [2013] sugeruje negatywny wpływ amitrazu na odporność pszczół na Nosema spp. Immunosupresyjny wpływ syntetycznych akarycydów na układ odpornościowy pszczół potwierdzają także Strachecka i in. [2012], którzy wykazali upośledzenie proteolitycznej bariery kutikuli pszczół na skutek działania amitrazu stosowanego w leku przeciw warrozie. Rolą proteolitycznej bariery powierzchni ciała pszczół jest m.in. ochrona przed inwazją grzybów. Okazało się, że działanie amitrazu nie jest wyjątkiem. Inną substancją czynną stosowaną wcześniej przeciw warrozie jest bromfenwinfos (związek fosforoorganiczny, z grupy estrów kwasu fosforowego). Bromfenwinfos także zmniejsza aktywność układów proteolitycznego i antyoksydacyjnego, a przy tym istotnie zwiększa stopnień zakażenia pszczół grzybami Nosema spp. [Strachecka i in. 2016]. Szkodliwy wpływ na immunologiczne funkcje powierzchni ciała pszczół mogą wywierać również kwasy organiczne [Strachecka i in. 2012]. W tym kontekście 
obserwowane przez pszczelarzy negatywne skutki stosowania ich jako akarycydów wydają się zrozumiałe.

\section{Substancje hamujące inwazję Nosema spp.}

Przez lata do zwalczania nosemozy u pszczół miodnych stosowano preparaty antybiotyczne oparte na fumagilinie [Gajda 2010]. Od czasu wprowadzenia zakazu jej stosowania, wynikającego z braku ustalonego górnego limitu dopuszczalnych pozostałości tej substancji w produktach pszczelich [European Union 1990], nie ma leku, który byłby wystarczająco skuteczny w zwalczaniu nosemozy pszczół. Dlatego prowadzone są intensywne badania w celu znalezienia substancji ograniczających rozwój grzybów Nosema spp. [Borsuki in. 2013]. Jedną $\mathrm{z}$ takich substancji może być nanosrebro. Wykazano, że nanosrebro w stężeniu 25 ppm podawane w syropie cukrowym może ograniczać inwazję Nosema spp. [Borsuk i in. 2013].

Analogiczny efekt uzyskano przez aplikację kurkuminy, w dawce $3 \mu \mathrm{g} / \mathrm{ml}$ (odpowiednik dawki dla człowieka). Wynika to zapewne z właściwości biostymulacyjnych tej substancji, które wpływają na poprawę kondycji i witalności pszczół oraz wydłużenie ich życia. Kurkumina ogranicza syntezę związków potrzebnych do budowy błon komórkowych grzybów oraz działa antyoksydacyjnie na organizmy pszczół. Dodatkowo może wspomagać usuwanie komórek uszkodzonych przez grzyby Nosema spp. z przewodu pokarmowego pszczół [Strachecka i in. 2015]. W warunkach laboratoryjnych także kofeina wpływa hamująco na rozwój Nosema spp. Działanie to można przypisać wysokiej aktywności układu proteolitycznego, w szczególności inhibitorów proteaz, które najprawdopodobniej doprowadzają do zahamowania łańcucha rozwojowego Nosema spp. dzięki swojej aktywności lub zmniejszenie dostępności aminokwasów niezbędnych do produkcji białek pasożyta [Mello i Silva-Filho 2002, Strachecka i in. 2014].

Przy profilaktyce nosemozy dużą rolę odgrywa pszczelarz, gdyż zapobieganie chorobie polega na przestrzeganiu zasad higieny i stworzeniu rodzinom pszczelim korzystnych warunków bytowania. Szczególną uwagę należy zwrócić na zapewnienie pokarmu odpowiedniej jakości, zwłaszcza pyłku, oraz suchego gniazda w czasie zimy, okresową wymianę plastrów i ich dezynfekcję przed ponownym użyciem, jeśli pochodzą z rodzin chorych. Rozprzestrzenianie się choroby ogranicza też zapobieganie rabunkom i błądzeniu pszczół [Gliński i in. 2006].

\section{Bibliografia}

Alaux C., Brunet J.-L., Dussaubat C., Mondet F., Tchamitchan S., Cousin M., Brillard J., Baldy A., Belzunces L.P., Le Conte Y., 2010. Interactions between Nosema microspores and a neonicotinoid 
weaken honeybees (Apis mellifera). Environ. Microbiol. 12, 774-782. https://doi.org/10.1111/j.14622920.2009.02123.x

Borsuk G., Paleolog J., Olszewski K., Strachecka A.J., 2013. Laboratory assessment of the effect of nanosilver on longevity, sugar syrup ingestion, and infection of honeybees with Nosema spp. Med. Weter. 69(12), 730-732.

Chen Y.P., Evans J.D., Murphy C., Gutell R., Zuker M., Gundensen-Rindal D., Pettis J.S., 2009. Morphological, molecular, and phylogenetic characterization of Nosema ceranae, a microsporidian parasite isolated from the european honey bee, Apis mellifera. J. Eukaryot. Microbiol. 56(2), 142-147. https://doi.org/10.1111/j.1550-7408.2008.00374.x

Chen Y.P., Evans J.D., Smith I.B., Pettis J.S., 2008. Nosema ceranae is a long-present and widespread microsporidian infection of the European honey bee (Apis mellifera) in the United States. J. Invertebr. Pathol. 97(2), 186-188. https://doi.org/10.1016/j.jip.2007.07.010

Chen Y.W., Chung W.P., Wang C.H., Solter L.F., Huang W.F., 2012. Nosema ceranae infection intensity highly correlates with temperature. J. Invertebr. Pathol. 111(3), 264-267. https://doi.org/10.1016/j.jip.2012.08.014

Copley T.R., Jabaji S.H., 2012. Honeybee glands as possible infection reservoirs of Nosema ceranae and Nosema apis in naturally infected forager bees. J. Appl. Microbiol. 112, 15-24. https://doi.org/10.1111/j.1365-2672.2011.05192.x

Czekońska K., 2007. Influence of carbon dioxide on Nosema apis infection of honeybees (Apis mellifera). J. Invertebr. Pathol. 95, 84-86. https://doi.org/10.1016/j.jip.2007.02.001

European Union (European Economic Community), 1990. COUNCIL REGULATION (EEC) No 2377/90 laying down a Community procedure for the establishment of maximum residue limits of veterinary medicinal products in foodstuffs of animal origin.

Forsgren E., Fries, I., 2010. Comparative virulence of Nosema ceranae and Nosema apis in individual European honey bees. Vet. Parasitol. 170, 212-217. https://doi.org/10.1016/j.vetpar.2010.02.010

Fries I., 2010. Nosema ceranae in European honey bees (Apis mellifera). J. Invertebr. Pathol. 103, 73-79. https://doi.org/10.1016/j.jip.2009.06.017

Fries I., Chauzat M.P., Chen Y.P., Doublet V., Genersch E., Gisder S., Higes M., McMahon D.P., Martín-Hernández R., Natsopoulou M.E., Paxton R.J., Tanner G., Webster T.C., Williams G.R., 2013. Standard methods for Nosema research. J. Apic. Res. 52, 1-28. https://doi.org/10.3896/IBRA.1.52.1.14

Fries I., Feng F., da Silva A., Slemenda S.B., Pieniążek N.J., 1996. Nosema ceranae n. sp. (Microspora, Nosematidae), morphological and molecular characterization of a microsporidian parasite of the Asian honey bee Apis cerana (Hymenoptera, Apidae). Eur. J. Protistol. 32, 356-365. https://doi.org/10.1016/S0932-4739(96)80059-9

Gajda A., 2010. Nosema ceranae w rodzinach pszczoły miodnej. Życie Weter. 85, 140-143.

Gisder S., Hedtke K., Möckel N., Frielitz M.-C., Linde A., Genersch E., 2010. Five-year cohort study of Nosema spp. in Germany: does climate shape virulence and assertiveness of Nosema ceranae? Appl. Environ. Microbiol. 76, 3032-3038. https://doi.org/10.1128/AEM.03097-09

Gliński Z., Kostro K., Luft-Deptuła D., 2006. Choroby pszczół. PWRiL, Warszawa.

Godfray H.C.J., Blacquière T., Field L.M., Hails R.S., Petrokofsky G., Potts S.G., McLean A.R., 2015. A restatement of the natural science evidence base concerning neonicotinoid insecticides and insect pollinators. Proc. R. Soc. Lond., B Biol. Sci. 281(1786). https://doi.org/10.1098/ rspb.2015.1821

Graaf D.C. de, Jacobs F.J., 1991. Tissue specificity of Nosema apis. J. Invertebr. Pathol. 58, 277-278.

Higes M., Martín-Hernández R., Meana A., 2010. Nosema ceranae in Europe: an emergent type C nosemosis. Apidologie 41, 375-392. https://doi.org/10.1051/apido/2010019

Howis M., Chorbiński P., Nowakowski P., 2010. Wpływ ekspozycji kwasu mrówkowego na stan fizjologiczny jelita środkowego pszczoły miodnej. XLVII Nauk. Konf. Pszczel. Puławy, 21.

Jones J.C., Oldroyd B.P., 2006. Nest thermoregulation in social insects. Adv. Insect Physiol. 33, 153-191. https://doi.org/10.1016/S0065-2806(06)33003-2

Kevan P.G., Guzman E., Skinner A., Van Englesdorp D., 2005. Colony collapse disorder in Canada: do we have a problem? Am. Bee J. 144, 507-509. 
Lockett G.A., Helliwell P., Maleszka R., 2010. Involvement of DNA methylation in memory processing in the honey bee. NeuroReport 21(12), 812-816. https://doi.org/10.1097/WNR.0b013e32833ce5be

Łoś A., Bieńkowska M., Strachecka A.J., 2019. Pszczoła miodna jako alternatywny, bezkręgowy organizm modelowy. Med. Weter. 75, 93-106. http://dx.doi.org/10.21521/mw.6140

Martins E., Mestriner M.A., Contel E.P.B., 1977. Alcohol dehydrogenase polymorphism in Apis mellifera. Biochem. Genet. 15, 357-366.

Mędrzycki P., Giffard H., Aupinel P., Belzunces L.P., Chauzat M.-P., Claßen C.,Vidau C., 2013. Standard methods for toxicology research in Apis mellifera. J. Apic. Res. 52(4), 1-60. https://doi.org/10.3896/IBRA.1.52.4.14

Mello M.O., Silva-Filho M.C., 2002. Plant-insect interactions: an evolutionary arms race between two distinct defense mechanisms. Brazilian J. Plant Physiol. 14, 71-81. https://doi.org/ $10.1590 / \mathrm{S} 1677-04202002000200001$

Michalczyk M., Sokół R., 2014. Nosemosis in honey bees. Polish J. Nat. Sci. 29, 91-99.

Olszewski K., 2013. Biologia, użytkowość oraz oporność na Varroa Destructor rodzin pszczelich utrzymywanych na plastrach na małych komórkach. Rozprawa habilitacyjna. Wydawnictwo Uniwersytetu Przyrodniczego, Lublin.

Paxton R.J., Klee J., Korpela S., Fries I., 2007. Nosema ceranae has infected Apis mellifera in Europe since at least 1998 and may be more virulent than Nosema apis. Apidologie 38, 558-565. https://doi.org/10.1051/apido:2007037

Pettis J.S., Van Engelsdorp D., Johnson J., Dively, G., 2012. Pesticide exposure in honey bees results in increased levels of the gut pathogen Nosema. Naturwissenschaften 99(2), 153-158.

Ptaszyńska A.A., Mułenko W., 2013. Wybrane aspekty budowy, taksonomii oraz biologii rozwoju mikrosporydiów z rodzaju Nosema. Med. Weter. 69, 716-725.

Ptaszyńska A.A., Borsuk G., Mułenko W., Olszewski K., 2012. Monitoring of nosemosis in the Lublin region and preliminary morphometric studies of Nosema spp. spores. Med. Weter. 68, $622-625$

Ptaszyńska A.A., Borsuk G., Mułenko W., Olszewski K., 2013. Impact of ethanol on Nosema spp. infected bees. Med. Weter. 69, 736-740.

Retschnig G., Williams G.R., Schneeberger A., Neumann P., 2017. Cold ambient temperature promotes Nosema spp. intensity in honey bees (Apis mellifera). Insects 8, 1-12. https://doi.org/ $10.3390 /$ insects 8010020

Roman A., 2003. Wplyw stanu toksykologicznego miodu na poziom kumulacji wybranych pierwiastkow śladowych w organizmie pszczoly miodnej (Apis mellifera L.). Acta Agrophys. 1(2), 295-300.

Settele J., Gallai N., Vaissière B.E., Salles J-M., 2009. Economic valuation of the vulnerability of world agriculture confronted with pollinator decline. Ecol. Econ. 68(3), 810-821. https://doi.org/10.1016/j.ecolecon.2008.06.014

Strachecka A.J., Paleolog J., Olszewski K., Borsuk G., 2012. Influence of amitraz and oxalic acid on the cuticle proteolytic system of Apis mellifera $L$. workers. Insects 3, 821-832. https://doi.org/10.3390/insects3030821

Strachecka A.J., Krauze M., Olszewski K., Borsuk G., Paleolog J., Merska M., Chobotow J., Bajda M., Grzywnowicz K., 2014. Unexpectedly strong effect of caffeine on the vitality of western honeybees (Apis mellifera). Biochemistry (Moscow) 79, 1192-1201.

Strachecka A.J., Olszewski K., Paleolog J., 2015. Curcumin stimulates biochemical mechanisms of Apis mellifera resistance and extends the apian life-span. J. Apic. Sci. 59, 129-141. https://doi.org/10.1515/jas-2015-0014

Strachecka A.J., Olszewski K., Paleolog J., 2016. Varroa treatment with bromfenvinphos markedly suppresses honeybee biochemical defence levels. Entomol. Exp. Appl. 160, 57-71. https://doi.org/10.1111/eea.12451

Suchail S., Guez D., Belzunces L.P., 2001. Discrepancy between acute and chronic toxicity induced by imidacloprid and its metabolites in Apis mellifera. Environ. Toxicol. Chem. 20(11), 2482-2486. https://doi.org/10.1002/etc.5620201113 
Trujillo J., Chirino Y.I., Molina-Jijón E., Andérica-Romero A.C., Tapia E., Pedraza-Chaverrí J., 2013. Renoprotective effect of the antioxidant curcumin: Recent findings. Redox Biol. 1, 448-456. https://doi.org/10.1016/j.redox.2013.09.003

Webster T.C., Pomper K.W., Hunt G.J., Thacker E.M., Jones S.C., 2004. Nosema apis infection in worker and queen Apis mellifera. Apidologie 35, 49-54. https://doi.org/10.1051/apido:2003063

Winston M.L., 1991. The biology of the honey bee. Harvard University Press, Harward. 


\author{
Martyna Frątczak ${ }^{1,3}$, Patrycja Małysz ${ }^{1}$, Marta Dybczyńska ${ }^{1}$, \\ Elżbieta Wnuk-Pawlak ${ }^{2}$
}

\title{
Powstanie i hodowla krajowa rasy konik polski
}

Genesis and domestic breeding of polish horses

Pochodzenie koni rasy konik polski nie zostało do końca wyjaśnione [Tomczyk-Wrona 2017]. Według wielu źródeł pochodzą wywodzą się one od wymarłego przodka, tarpana (Equus caballus gmelini Ant.), który zamieszkiwał leśne tereny Europy. Zależnie od szkoły hipologicznej tarpany uznaje się za pierwotnie dzikie lub też wtórnie zdziczałe konie, żyjące kiedyś w Polsce i we wschodniej części naszego kontynentu [Janczarek i in. 2017]. Geneza ta nie została jednak potwierdzona z powodu braku dostatecznej ilości materiału genetycznego wymarłych zwierząt, jest jednak najbardziej prawdopodobna ze względu na podobieństwo fenotypowe osobników.

W XVIII w. na terenach Polski, Litwy i Prus występowały dzikie konie nazywane końmi leśnymi lub tarpanami, co udokumentowano w zapiskach podróżników oraz kronikach. Około 1780 r. odłowiono ostatnie osobniki i przeniesiono je na tereny ordynacji hrabiów Zamojskich w Zwierzyńcu k. Biłgoraja [PZHK 2010]. Dopiero w XX w. prof. Tadeusz Vetulani wpłynął na przyjęcie się nazwy „konik polski” w literaturze oraz na stworzenie pierwszego programu ochrony ich bioróżnorodności. W 1936 r. utworzył w Puszczy Białowieskiej rezerwat koników, aby odtworzyć leśną odmianę tych zwierząt. Początkowo osobniki poddane programowi były nieznanego pochodzenia, ale w 1955 r. powstał pierwszy rejestr koników polskich, będący podstawą ksiąg stadnych. W kolejnych latach hodowla powoli rozprzestrzeniała się na całą Polskę.

Tarpany miały ok. $130 \mathrm{~cm}$ w kłębie i ostro zakończone uszy. Ich głowa charakteryzowała się wklęsłym profilem czoła, osadzeniem na krótkiej, często jeleniej szyi, a także sterczącym włosiem grzywy [Jaworski i in. 2018]. Koniki nie miały kasztanów lub były one bardzo małe, a dolne części kończyn były ciemniejsze od barwy sierści. Najbardziej charakterystyczne dla tych koni było umaszczenie myszate oraz specyficzna czarna pręga wzdłuż kręgosłupa. Wzorzec pokroju i umaszczenia konika polskiego został dokładnie określony w pro-

\footnotetext{
1 Uniwersytet Przyrodniczy w Lublinie, Wydział Nauk o Zwierzętach i Biogospodarki, Studencckie Koło Naukowe Nauk o Zwierzętach i Biogospodarki, Sekcja Hipologiczna

${ }^{2}$ Uniwersytet Przyrodniczy w Lublinie, Wydział Nauk o Zwierzętach i Biogospodarki, Katedra Hodowli i Użytkowania Koni

${ }^{3}$ martyna.fratczak97@gmail.com
} 
gramie hodowli zachowawczej [Jaworski i in. 2007], następnie w Programie zasobów genetycznych koni rasy konik polski w opracowaniu Jaworskiego i Tomczyk-Wrony [2010], a ostatecznie uściślony w programie hodowli stworzonym na podstawie Księgi Pochodzenia Koni Rasy Konik Polski [PZHK 2017]. Księga Stadna Koników Polskich od 1984 r. jest księgą typu zamkniętego, obecnie prowadzona jest jedynie księga główna. Wiąże się to z utrzymywaniem rasy w czystości, bez dolewu krwi innych ras. Wszystkie spisy były i są prowadzone jedynie na terenie Polski, więc rasa nazywana jest krajową. Aktualnie koniki polskie zaliczane są do grupy koni prymitywnych, które powinny cechować się bogatym uwłosieniem grzywy i ogona. Standard wysokości w kłębie koni dorosłych wynosi $130-140 \mathrm{~cm}$, obwód nadpęcia ogierów $17,5 \mathrm{~cm}$, klaczy $16,5 \mathrm{~cm}$, a obwód klatki piersiowej ok. $30 \mathrm{~cm}$ więcej niż osobnicza wysokość w kłębie [Jaworski i Tomczyk-Wrona 2010]. Warunkiem wpisu do sekcji głównej Księgi jest umaszczenie myszate o odcieniach myszatym, jasno-, bułano- oraz ciemnomyszatym, bez żadnych odmian (fot. 1). Wpis do klasy II Księgi klaczy pozwala na niewielkie odmiany na głowie i kończynach. Charakterystyczna jest także ciemna pręga przechodząca wzdłuż linii kręgosłupa oraz pręgowania na nogach [Jaworski i Tomczyk-Wrona 2010]. Oprócz cech eksterierowych, koniki mają dużą wytrzymałość, są odporne na choroby, a także z łatwością przystosowują się do trudnych warunków bytowania. Dzięki temu łatwo sprostać ich wymaganiom pokarmowym i osobniczym. Posiadają też żywy, lecz zrównoważony temperament oraz są łagodne i przyjazne w stosunku do człowieka, dlatego istnieje możliwość wszechstronnego wykorzystania tych zwierząt.

Hodowla zachowawcza zakłada, że poszczególne cechy zostaną utrwalone na obecnym poziomie lub udoskonalane, bez wpływania w znacznym stopniu na typ rasowy [Geringer i Pasicka 2012]. Prowadzona jest selekcja stabilizująca, co oznacza, że utrwalane są cechy eksterieru charakterystyczne dla tarpanów, a doskonalona jest m.in. jakość chodów i cechy związane z użytkowaniem rekreacyjnym, głównie psychiczne. Aktualnie koniki użytkowane są przede wszystkim wierzchowo oraz zaprzęgowo, w rekreacji, hipoterapii oraz sporcie amatorskim. Ponadto, koniki polskie mają duże zastosowanie w czynnej ochronie przyrody i kształtowaniu krajobrazu [Janczarek i in. 2017]. Według przeprowadzonych badań zmiany gospodarcze oraz zmieniające się preferencje hodowców i użytkowników powodują selekcję w kierunku uzyskania konika polskiego typowo wierzchowego. Obecnie kontrola i ocena wartości użytkowej jest prowadzona za pomocą polowych zaprzęgowych i wierzchowych prób dzielności, Wszechstronnego Konkursu Konika Polskiego (WKKP) oraz poprzez selekcję i dobór osobników do kojarzeń [Jaworski i Tomczyk-Wrona 2010]. 


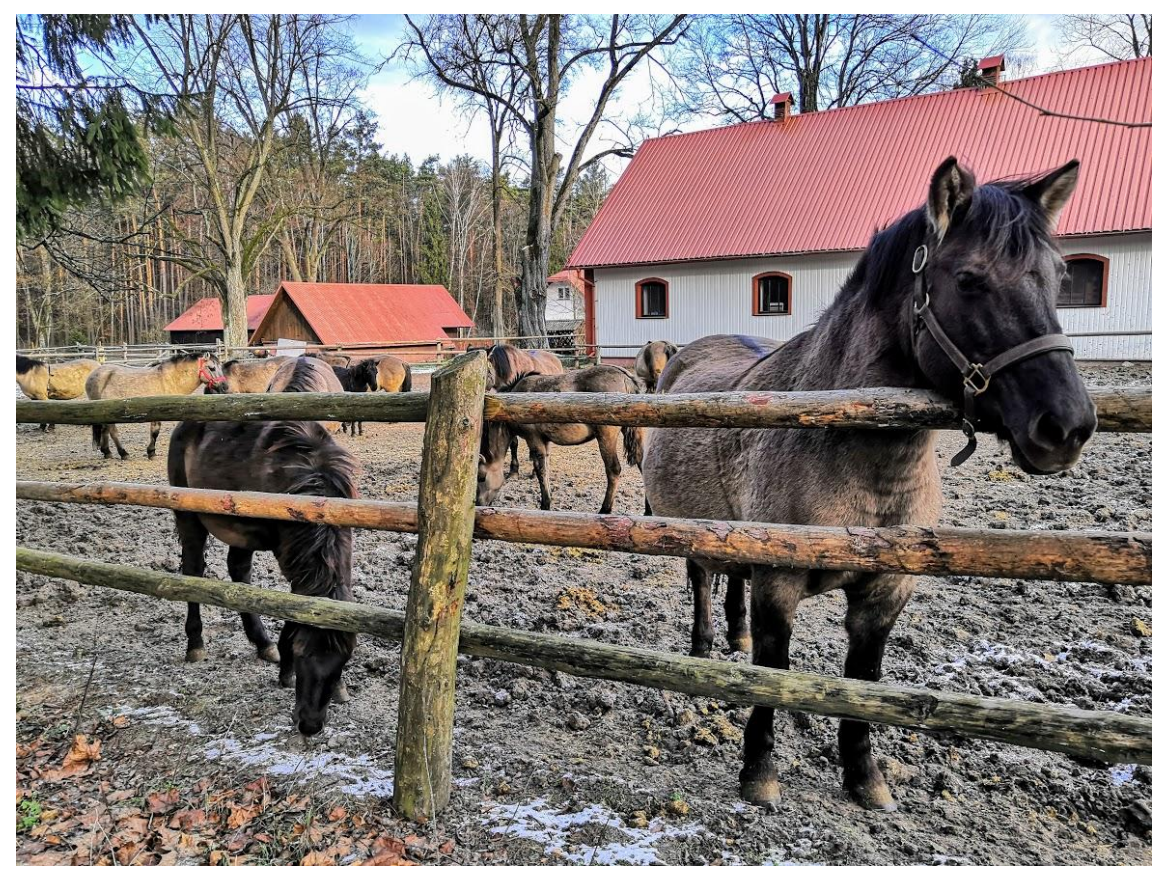

Fot. 1. Koniki polskie - Ośrodek Hodowli Zachowawczej RPN we Floriance k. Zwierzyńca (fot. M. Frątczak)

Obecnie koniki polskie są rasą ujednoliconą pod względem pokrojowym, czego dowodem są m.in. wyniki obowiązkowej bonitacji pokroju [Pluta $\mathrm{i}$ in. 2016]. Podczas oceny obejmującej typ (do 15 pkt), głowę i szyję (5 pkt), kłodę (15 pkt), kończyny przednie oraz tylne, kopyta, chody w stępie i kłusie (po 10 pkt) oraz wrażenie ogólne (15 pkt) zwierzę może otrzymać maksymalnie 100 pkt [PZHK 2018]. Wahania punktowe między poszczególnymi osobnikami są niewielkie, co wynika ze sposobu prowadzenia hodowli, spójnego pod względem genetycznym. Stwierdzenie potwierdza fakt, że koniki z chowu rezerwatowego, mimo różnic $\mathrm{w}$ rozwoju wynikających $\mathrm{z}$ odmiennego środowiska, nie odbiegają znacząco od pokroju osobników, które utrzymywane są w systemie stajennym [Pluta i in. 2016]. Surowe warunki i sezonowość dojrzewania koni żyjących w warunkach zbliżonych do naturalnych wpływają na osiągnięcie całkowitej dojrzałości zwierząt, wydłużającej się nawet do 5 roku życia. Mimo to jedyne udokumentowane różnice pomiędzy konikami utrzymywanymi w tych dwóch systemach stwierdzono w wielkości obwodu i głębokości klatki piersiowej, przy czym lepsze wyniki uzyskały zwierzęta $z$ chowu stajennego [Janczarek $\mathrm{i}$ in. 2017].

Jednym z etapów pracy hodowlanej jest selekcja osobników o pożądanych cechach użytkowych i/lub pokrojowych [Jaworski i Tomczyk-Wrona 2010]. Zakłada ona wybór osobników, których potomstwo będzie posiadało zestaw pożądanych genów odziedziczonych po rodzicach. Konie przekazujące oczeki- 
wane cechy dalszym pokoleniom to zwierzęta, które mają wysoką wartość hodowlaną [Kaproń i Janczarek 2014]. Proces hodowlany jest jednak trudny ze względu na niską odziedziczalność wielu ważnych cech, nieprzewidzialne interakcje między środowiskiem a genotypem oraz inne bliżej nieznane utrudnienia [Geringer i in. 2004]. Sukcesem hodowlanym jest uzyskanie osobników udoskonalonych genetycznie, co jest miarą postępu genetycznego. Zwierzęta najlepsze z punktu widzenia hodowlanego są najważniejszym elementem tworzenia populacji i ułatwiają hodowlę zachowawczą konika polskiego. Wartość hodowlana oceniana jest też na podstawie rodowodu - pod kątem wartości użytkowej przodków i oceny rozwoju młodzieży hodowlanej, najpierw jako źrebiąt przy matkach, a następnie jako roczniaków i dwulatków [Jaworski i Tomczyk-Wrona 2010]. Hodowla koników z warunków rezerwatowych jest kontrolowana w stopniu minimalnym, metodami zootechnicznymi [Jaworski 2003]. Brakowane są osobniki o nieodpowiedniej maści i dużych wadach pokroju. Istotną rolę odgrywa selekcja naturalna, dzięki której populacja rezerwatowa nabiera odporności na trudne warunki środowiskowe, ograniczony dostęp do pożywienia i brak stałego schronienia. Zwiększa się również odporność immunologiczna ich organizmów, rozwijają się pożądane cechy rozpłodowe i zdolność do samodzielnego odchowywania potomstwa. Koniki nabywają także cech zachowania umożliwiających życie w stadzie. W hodowli stajennej i bezstajennej selekcja jest bardziej rygorystyczna [Pluta i in. 2016]. Składa się z dwóch etapów. Pierwszy jest oceną na podstawie eksterieru i rozwoju psychicznego, drugi natomias - wyników prób użytkowości oraz użytkowości rozpłodowej. Po ukończeniu 5 roku życia, konie wpisane do Księgi Głównej Ogierów lub Klaczy, biorące udział w „Programie hodowli zachowawczej koników polskich”, muszą być poddane weryfikacji wymiarów ciała oraz poprzednio uzyskanej oceny bonitacyjnej [Jaworski i in. 2007]. Koniki utrzymywane w systemie stajennym i półstajennym poddawane są także próbom dzielności, alternatywnemu Wszechstronnemu Konkursowi Konika Polskiego lub czempionatom, pokazom i wystawom [Jaworski i Tomczyk-Wrona 2010]. Próby użytkowości rozpoczyna próba wstępna, obligatoryjna dla ogierów i klaczy zakwalifikowanych do programu hodowli zachowawczej. Ocenia się charakter, temperament, energiczność i ogólne zachowanie konia podczas zakładania ogłowia, trzymania do oceny oraz prowadzenia w stępie i kłusie. Kolejnym obowiązkowym elementem dla 3-4-letnich ogierów jest polowa próba wierzchowa lub zaprzęgowa, kwalifikująca osobniki jedynie po uzyskaniu pozytywnego wyniku końcowego. Klacze muszą zaliczyć próbę w ciągu 4 lat od daty wpisu do Księgi. Próby użytkowości nie dotyczą koników rezerwatowych. Każdorazowo określeniem szczegółowych warunków próby zajmuje się komisja powołana przez prowadzącego Księgi. Ocena składa się ze stałych elementów dla obydwu rodzajów użytkowości. Są to ocena zachowania, pomiar czasu przebycia odcinka $500 \mathrm{~m}$ najpierw w stępie, a następnie w kłusie, pomiar długości kroku w obydwu chodach, ocena wybranego wariantu próby wysiłkowej, pomiar tętna $\mathrm{i}$ oddechów na koniec próby oraz porównanie tych parametrów $\mathrm{z}$ warto- 
ściami początkowymi. W 2014 r. ustalono i uznano WKKP jako alternatywną próbę dzielności koników polskich [Słomiany 2016]. Jest to forma jeździectwa rekreacyjnego. Składa się z 3 prób, czyli rajdu, ścieżki i wyścigu. Udział w tej próbie biorą konie 3-letnie, które posiadają udokumentowane pochodzenie (warunek konieczny). Ukończenie wszystkich części zalicza próbę dzielności [Siemieniuch i Jaworski 2020]. Mimo początkowych wątpliwości hodowców, ten sposób selekcji nie wpłynął znacząco na fenotyp koników polskich. Nie zauważono zmian cech psychicznych i fizycznych mogących uniemożliwić ich użytkowanie [Janczarek $\mathrm{i}$ in. 2017].

Według „Programu hodowli zachowawczej koników polskich”, osobniki utrzymywane są w systemie tabunowym, stajennym lub półstajennym [Jaworski i in. 2018]. Hodowla rezerwatowa, w której konie przez cały rok znajdują się $\mathrm{w}$ naturalnym środowisku $\mathrm{w}$ grupach haremowych złożonych $\mathrm{z}$ kilku klaczy wraz z przychówkiem oraz ogiera, jest typem chowu tabunowego. Stadem rządzi najbardziej doświadczona klacz, która pełni rolę przewodniczki. Ogier w takim systemie jest reproduktorem oraz obrońcą. Materiałem hodowlanym są tylko osobniki, które pochodzą z hodowli rezerwatowej, z wyjątkiem potrzeby zwiększenia różnorodności genetycznej populacji przez zwierzę wybrane z innych rodzajów utrzymania. O uznaniu rezerwatu decyduje Komisja Księgi Stadnej Koni Rasy Konik Polski [PZHK 2010]. Dzięki temu rodzajowi hodowli potwierdzono wartościowe cechy koników, takie jak dobra rozrodczość, długowieczność, odporność i przystosowanie do lokalnych warunków środowiska. Mogą mieć one wpływ na wykorzystanie genów koników w doskonaleniu innych ras. Hodowla bezstajenna polega na udostępnieniu konikom dużych pastwisk, na których, na wypadek złych warunków pogodowych, znajduje się dostępne dla zwierząt zadaszenie. W hodowli stajennej konie w okresie pastwiskowym przebywają na pastwiskach, a w okresie zimowym w stajni i na wybiegach [Pluta i in. 2016].

Hodowla konika polskiego jest prowadzona przede wszystkim na terenie Polski, ale przedstawicieli tej rasy można spotkać także w Holandii, Niemczech, Francji, Belgii i Wielkiej Brytanii [PZHK 2010]. Jednym z głównych ośrodków hodowlanych w Polsce jest Popielno, gdzie w 1955 r., 3 lata po śmierci prof. Vetulaniego wznowiono eksperyment nad restytucją tarpana leśnego. Hodowla prowadzona jest tam do dzisiaj, w dwóch systemach utrzymania: rezerwatowym - na ok. 1620 ha terenów leśno-łąkowych, a także stajennym [Pasicka 2013, www.popielno.pl].

Koniki polskie pojawiły się w Roztoczańskim Parku Narodowym 16 lipca 1982 r. Właśnie wtedy w Zwierzyńcu rozpoczęto hodowlę rezerwatową koników w miejscu nazwanym „Ostoją”. Początkowo rezerwat miał powierzchnię ok. 40 ha, w kolejnych latach sukcesywnie ją powiększano. Obecnie wynosi ok. 210 ha. W 1996 r. w dawnym folwarku Florianka osiedlono te zwierzęta w systemie stajennym. Był to swego rodzaju powrót koników do miejsca, gdzie w latach 1780-1806 utrzymywano dzikie tarpany [Hroboni 1959]. Całą hodowlę konika polskiego 
w RPN nazwano Ośrodkiem Hodowli Zachowawczej Konika Polskiego, a w 2010 r. zmieniono ją na Ośrodek Hodowli Zachowawczej. Taki ośrodek powstał również w Biebrzańskim Parku Narodowym pod koniec 2004 r. [Pasicka 2013]. Zwierzęta utrzymywano tam w hodowli rezerwatowej, w systemie tabunowym, na ok. 200 ha przestrzeni naturalnych łąk bagiennych i terenów leśnych [Doboszewski 2017]. Od 2017 r. koniki mogą poruszać się bez ograniczeń po obszarach parku na ok. 2000 ha, utrzymując w odpowiednim stanie faunę oraz florę rzadką oraz zagrożoną wyginięciem.

Kolejne miejsce, które zamieszkują koniki polskie, to ostoja w Zielonym Ostrowie. Ośrodek ten powstał w 1990 r., zaś w 2004 r. został dołączony do rezerwatu przyrody Jeziora Siedmiu Wysp [Pasicka 2013]. Obecność koników polskich wpłynęła na spowolnienie sukcesji roślin na tym obszarze. W $2007 \mathrm{r}$. w Miliczu zwierzęta te zamieszkały na terenie ok. 200 ha, nad Stawami Milickimi oraz w pobliskich lasach należących do Parku Krajobrazowego „Dolina Baryczy". W 2010 r. powstał ośrodek znajdujący się w Nadleśnictwie Kliniska, należącym terytorialnie do Puszczy Goleniowskiej, o powierzchni ok. 655 ha. Obecność koników w hodowlach rezerwatowych przyczynia się do czynnej ochrony przyrody i pozwala na spowolnienie rozrastania się drzew i krzewów [Jaworski i in. 2018]. Stado Ogierów Sieraków zostało w 2010 r. włączone do struktur Przedsiębiorstwa Rolniczo-Hodowlanego „Gałopol”, co dało przedsiębiorstwu nowe zadania hodowlane. Realizowany jest w nim program ochrony zasobów genetycznych koników polskich w systemie stajennym. Od wielu lat organizowana jest tam również największa ogólnopolska wystawa hodowlana koników, nazywana Tarpaniadą, oraz próby dzielności tej rasy. Ośrodek hodowli zachowawczej konika polskiego w stadninie koni w Dobrzyniewie powstał natomiast w 1979 r. Dzięki odpowiednim założeniom pracy hodowlanej uzyskano tam stado bardzo wyrównane pokrojowo [www.skdobrzyniewo.pl 2020]. Na terenie Polski znajdują się również inne, mniej znane ośrodki hodowlane. W hodowli prywatnej przeważają tereny Wielkopolski, Mazur, Pomorza, Małopolski i Śląska.

Popularność hodowli rezerwatowej i bezstajennej zwiększa się nie bez przyczyny, zwłaszcza na terenach o walorach przyrodniczych. Badania, które były prowadzone przez 5 lat w Nadleśnictwie Kliniska, udowodniły, że utrzymanie wolnościowego tabunu w zagrodzie obejmującej część doliny rzeki Iny miało korzystny wpływ na bioróżnorodność znajdujących się tam siedlisk. Dodatkowo, na dużych terenach koniki mogą spełniać funkcje środowiskotwórczą, rekonstrukcyjną względem ekosystemów oraz pielęgnacyjną wobec krajobrazu, czym wpisują się w założenia „Krajowej strategii zrównoważonego użytkowania i ochrony zasobów genetycznych zwierząt gospodarskich". 


\section{Bibliografia}

Doboszewski P., Doktór D., Jaworski Z., Kalski R., Kułakowska G., Łojek J., Płąchocki D., Ryś A., Tylkowska A., Zbyryt A., Górecka-Bruzda A., 2017. Konik polski horses as a mean of biodiversity maintenance in post-agricultural and forest areas: an overview of Polish experiences. Anim. Sci. Pap. Rep. 35(4), 333-347.

Geringer de Oedenberg H., Pasicka E., 2012. Analiza indeksów pokrojowych koników polskich z ośrodków hodowli zachowawczej oraz wykorzystywanych w hipoterapii. Zesz. Nauk. Uniw. Przyr. Wrock., Biol. Hod. Zwierząt 591, 9-21.

Geringer de Oedenberg H., Dobrowolski M., Zaton-Dobrowolska M., 2004. Odziedziczalność wybranych cech z prób dzielności ogierów w zakładach treningowych w latach 1977-2000. Zesz. Nauk. Prz. Hod. 72(5), 11-16.

Hroboni Z., 1959. Historyczny rys hodowli koni prymitywnych w Polsce. Rocz. Nauk Rol. 73(4), $625-721$.

Janczarek I., Pluta M., Paszkowska A., 2017. Pochodzenie, hodowla i użytkowanie koników polskich, Prz. Hod. 85(5), 6-10.

Jaworski Z., 2003. Ocena warunków etologiczno-hodowlanych koników polskich utrzymywanych w systemie rezerwatowym. Rozpr. Monogr. - Uniw. Warm.-Mazur. Olszt. 79, 1-89.

Jaworski Z., Jastrzębska E., Górecka-Bruzda A., 2018. Wypas koników polskich na terenach cennych przyrodniczo - kształtowanie krajobrazu i zachowanie bioróżnorodności. Prz. Hod. 5, $20-24$.

Jaworski Z., Kaproń M., Łukomski S., Słomiany J., 2007. Program hodowli zachowawczej koników polskich. Warszawa.

Jaworski Z., Tomczyk-Wrona I., 2010. Program ochrony zasobów genetycznych koni rasy konik polski. Załącznik nr 2 do Zarządzenia nr 19/10 z dn. 16 kwietnia 2010 r. Warszawa.

Kaproń M., Janczarek I., 2014. Selected performance parameters of Polish half-blooded mares. Anim. Sci. Pap. Rep. 32(2), 131-142.

Konie. Stadnina Koni w Dobrzyniewie. https://www.skdobrzyniewo.pl/konie.html [dostęp: 18.03.2020].

Koniki polskie. Stacja Badawcza w Popielnie - Stacja Badawcza Rolnictwa Ekologicznego i Hodowli Zachowawczej Zwierząt w Popielnie. http://popielno.pl/koniki-polskie/ [dostęp: 18.03.2020].

Konik polski. Roztoczański Park Narodowy. http://roztoczanskipn.pl/pl/ochrona-przyrody/ohz/konikpolski [dostęp: 18.03.2020].

Pasicka E., 2013. Polish Konik Horse - Characteristics and historical background of native descendants of Tarpan. Acta Sci. Pol. Med. Vet. 12(2-4), 25-38.

Pluta M., Osiński Z., Cieśla A., Kolstrung R., 2016. Genetic and phenotypic characteristics of Polish Konik horses maintained in the reserve and stable system in central-eastern Poland. Acta Sci. Pol. Zootech. 15(2), 59-76. https://doi.org/10.21005/asp.2016.15.2.06

PZHK, 2010. Księga stadna koni rasy konik polski, t. 9. Warszawa, 8-10.

PZHK, 2017. Księga pochodzenia koni rasy konik polski. Warszawa, 8-10.

PZHK, 2018. Program hodowli koni rasy konik polski. Warszawa, 4-7, 25-31.

Siemieniuch M., Jaworski Z., 2020. Analiza wyników polowych prób użytkowości koników polskich przeprowadzonych w 2018 roku. Prz. Hod. 88(1), 4-7.

Słomiany J.L., 2016. Sprawozdanie z działalności Komisji Księgi Stadnej Koni Rasy Konik Polski w latach 2014-2015. PZHK.

Tomczyk-Wrona I., 2017. Koniki polskie - modelowa populacja ochrony bioróżnorodności, Wiad. Zootech. 55(5), 98-103. 
Aleksandra Garbiec $^{1,2}$, Mirosław Karpiński ${ }^{1}$, Justyna Wojtaś ${ }^{1}$

\title{
Określanie poziomu stresu u zwierząt towarzyszących na podstawie poziomu kortyzolu $w$ różnych materiałach biologicznych
}

\author{
Determining the level of stress in companion animals on the basis of cortisol levels in various
} biological materials

Stres jest naturalną odpowiedzią organizmu na działanie stresora, polegającą na aktywacji układów nerwowego i endokrynnego. Reakcja stresowa spowodowana jest działaniem hormonów kory nadnerczy, głównie kortyzolu. Bodziec stresowy powoduje wzrost poziomu kortyzolu, co można zauważyć w odmiennym zachowaniu zwierzęcia [Beerda i in. 2000]. Stresor wywołuje szereg fizjologicznych zmian, które umożliwiają jednostce reakcję zgodną z wyzwaniem stawianym przez otoczenie [Olczak i in. 2014]. W zależności od długości oddziaływania czynnika na organizm wyróżniamy stres krótkotrwały i długotrwały. Rozwój medycyny weterynaryjnej i behawioralnej prowadzi do zgłębiania wiedzy o mechanizmie stresu oraz jego wpływie na zachowanie się i dobrostan zwierząt. W tym celu coraz popularniejsze staje się oznaczanie poziomu reakcji stresowej na podstawie stężenia kortyzolu w różnych materiałach biologicznych [Pyrczek i Stefaniak 2013].

Reakcja stresowa zachodzi dzięki aktywacji układu współczulnego oraz osi HPA (podwzgórze-przysadka-nadnercza). Jeśli na organizm zadziała jednorazowo krótkotrwały bodziec, dochodzi do pobudzenia układu współczulnego i wyrzutu hormonów o działaniu mobilizującym, tj. adrenaliny i noradrenaliny, co powoduje następnie wyrzut glukozy dostarczającej energię oraz przyspieszenie pracy serca i zwiększenie częstotliwości oddechu, aby zapewnić maksymalną wydolność organizmu w trakcie walki i/lub ucieczki od czynnika zagrażającego [Rooney i in. 2007]. Po kilku minutach, kiedy bodziec przestaje wypływać na organizm, wszystko wraca do równowagi. System podwzgórze-przysadka-nadnercza natomiast aktywuje się dopiero, gdy bodziec oddziałuje dłużej niż kilka minut. Podwzgórze pobudza przysadkę, wydzielając kortykoliberynę (CRH) [Skórzewska $i$ in. 2004]. Kortykoliberyna uważana jest za jeden z decydujących czynników reakcji organizmu na stres, rozpoczyna, reguluje i hamuje odpowiedź osi

\footnotetext{
${ }^{1}$ Uniwersytet Przyrodniczy w Lublinie, Wydział Nauk o Zwierzętach i Biogospodarki, Katedra Etologii Zwierząt i Łowiectwa

2 aleksandra.garbiec@up.lublin.pl
} 
HPA na działające bodźce. Przedni płat przysadki pod wpływem CRH wydziela ACTH - kortykotropinę (hormon adrenokortykotropowy). Kortykotropina zostaje przetransportowana do kory nadnerczy, która wydziela glikokortykoidy (m.in. kortyzol) [Landowski 2007] (rys. 1).

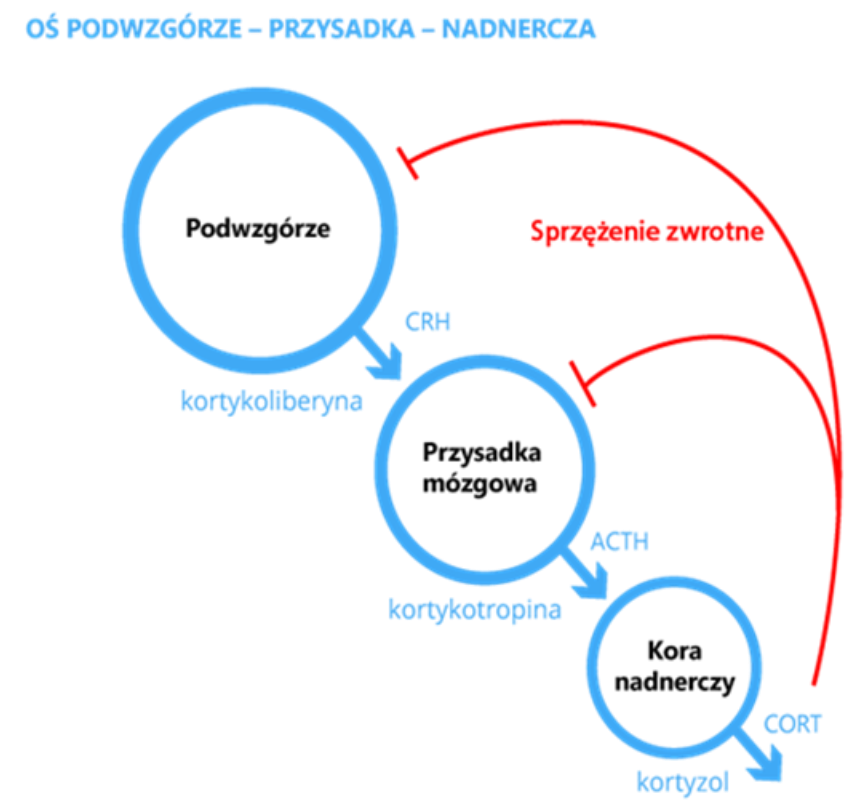

Rys. 1. Schemat osi HPA [http://forstress.pl/images/hpa.png]

Kortyzol powstaje z 11- $\beta$-deoksykortyzolu przy udziale 11- $\beta$-hydroksylazy w warstwie pasmowatej kory nadnerczy. Nazywany jest hormonem stresu ze względu na przynależność do związków mających wpływ na zwiększenie poziomu glukozy we krwi, występującego podczas reakcji stresowej. Co więcej, charakteryzuje się dłuższym okresem półtrwania (100 min) niż w przypadku adrenaliny i noradrenaliny oraz ma zdolność do wydłużania czasu ich działania, co zapewnia utrzymanie wysokiego tempa metabolizmu [Dziurkowska i Wesołowski 2010]. Zatem można stwierdzić, że glikokortykoidy ułatwiają przystosowanie organizmu do nowych, zmieniających się warunków otoczenia, a oś podwzgórze-przysadka-nadnercza jest regulatorem wydzielania hormonów nadnerczowych oraz wzbudza reakcję organizmu na stresor [Davenport $i$ in. 1998]. Wysoka wartość diagnostyczna kortyzolu jest coraz częściej wykorzystywana do określania rodzaju i natężenia stresu [Hennessy i in. 1997], a także służy do oceny poziomu dobrostanu u zwierząt gospodarskich i towarzyszących [Marć-Pieńkowska i in. 2014]. 
Ze względu na mechanizm i czas trwania wyróżniamy stres krótkotrwały oraz długotrwały. Krótkotrwały stres działa mobilizująco na organizm zwierzęcia, pełni funkcję adaptacyjną oraz wspomaga radzenie sobie $\mathrm{z}$ potencjalnym zagrożeniem bez spowodowania tym samym stałych zmian destrukcyjnych. Co więcej, krótkotrwały wzrost stężenia kortyzolu i kortykosteronu we krwi jest korzystny dla organizmu (eustres). Natomiast w sytuacji, gdy organizm doznaje stresu często lub przez długi czas, następują kolejne wyrzuty kortyzolu do krwi, zanim uprzednio uwolniona dawka nie zostanie z niej usunięta, a to doprowadza do nagromadzenia się kortyzolu i powstania stresu przewlekłego. Jest on stanem ciągle podniesionej gotowości organizmu do radzenia sobie z potencjalnym zagrożeniem, co powoduje stale przyspieszony metabolizm oraz duże straty energii, a w konsekwencji - stan wyczerpania. Stres chroniczny ma negatywny wpływ na organizm (dystres), wywołuje zmiany destrukcyjne m.in. w układach nerwowym, endokrynnym, trawiennym oraz immunologicznym. Stres chroniczny uznawany jest za główną przyczynę obniżenia dobrostanu zwierzęcia [Davenport i in. 1998].

Długotrwałe wydzielanie hormonów kortykotropowych może powodować zmiany strukturalne i funkcjonalne hipokampa, ciała migdałowatego i kory przedczołowej, co w rezultacie może prowadzić do zaburzeń behawioralnych (rys. 2). Przejawia się to zwiększonym niepokojem, impulsywnością oraz zaburzeniami kontroli hamowania [Olczak i in. 2014]. W warunkach przewlekłego stresu dochodzi do zaburzenia aktywności osi HPA i nadmiernej sekrecji hormonów steroidowych. Związany ze stresem chronicznym długotrwale utrzymujący się wysoki poziom kortyzolu zaburza gospodarkę białkową, węglowodanową, thuszczową oraz wodno-elektrolitową organizmu. Pod wpływem stresu dochodzi do zwiększonej sekrecji ACTH, a w następstwie do zwiększenia stężenia glikokoliykosteroidów, których wysoki poziom we krwi prowadzi do niedoborów energetycznych, może zaburzyć także regulację hormonalną oraz wywołać immunosupresję organizmu [Beerda i in. 1999].

Wyróżniamy szereg czynników, które mogą być potencjalnym źródłem stresu dla psów. Do najczęstszych przyczyn wystąpienia stresu ostrego zaliczamy silne bodźce krótkotrwałe, tj. hałas, wizytę $\mathrm{w}$ gabinecie weterynaryjnym, kontakt z innym psem, atak agresji czy paniki. Wszystkie czynniki działające dłużej, np. nowa osoba czy zwierzę w domu, przeprowadzka, niedożywienie, brak możliwości załatwiania potrzeb fizjologicznych (zbyt krótkie spacery, brak aktywności fizycznej czy eksploracji terenu), długo utrzymujący się ból czy izolacja zwierzęcia, mogą doprowadzić do stresu chronicznego, a tym samym do zaburzeń hormonalnych, metabolicznych i behawioralnych u psa [Olczak i in. 2014].

Opisywanych jest kilka reakcji zwierzęcia w odpowiedzi na stres: walka i ucieczka, znieruchomienie oraz załagodzenie lub wyczerpanie [Sadowski 2001]. Stadium wyczerpania pojawia się zwykle, gdy kończą się zasoby energetyczne, a sam organizm poddaje się wpływowi bodźca [Ottenheimer i in. 2013]. Okres ten jest pierwszym etapem przejścia stresu ostrego w przewlekły. Wiado- 
mo także, że długo trwający stres może spowodować trudność w zaobserwowaniu odpowiedzi organizmu, ponieważ np. zanikną charakterystyczne objawy behawioralne na skutek przystosowania do zwiększonego poziomu kortyzolu we krwi [Moberg i Mench 2000]. Zmiany zachowania zwierzęcia pod wpływem stresu są różne, każdy osobnik może zareagować odmiennie na ten sam bodziec. $\mathrm{Na}$ zachowanie psa wpływa wiele czynników, najważniejsze $\mathrm{z}$ nich to: wiek, płeć, doświadczenia życiowe (zarówno te negatywne, jak i pozytywne), rasa, temperament $\mathrm{i}$ inne, $\mathrm{w}$ tym uwarunkowania genetyczne oraz przebyte zabiegi weterynaryjne [Marć-Pieńkowska i in. 2014]. Do najczęstszych sygnałów uspokajających, jakie możemy zauważyć u psa próbującego poradzić sobie ze stresem, należą unikanie kontaktu wzrokowego poprzez opuszczenie pyska lub mrużenie oczu, częste oblizywanie luterka nosa, natarczywe ziewanie, ślinotok czy sztywność ciała. W sytuacji bezpośredniej konfrontacji z bodźcem silnie zestresowany pies może przyjąć postawę przynoszącą mu ulgę - położyć się na grzbiecie, niekontrolowanie oddać mocz i kał czy zareagować agresją.

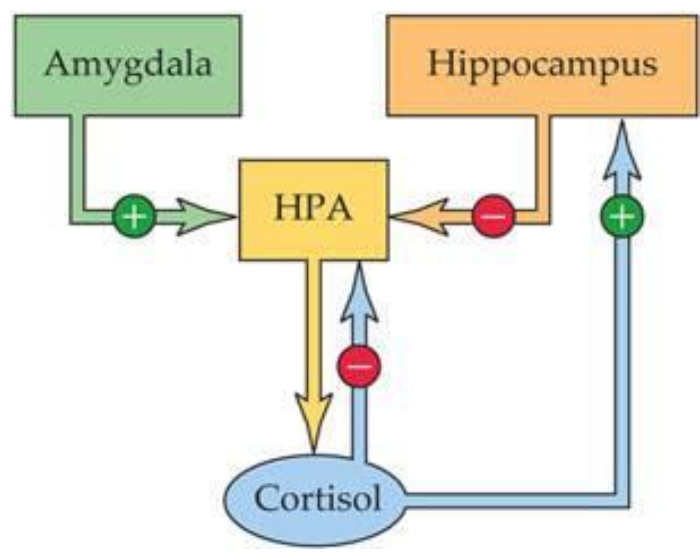

Rys. 2. Wpływ chronicznego stresu na hipokamp

[https://oup-arc.com/access/content/psychopharmacology-3e-student-resources/psychopharmacology3e-web-box-17-2-pharmacology-in-action-early-experience-and-stress]

Istnieje szereg sygnałów behawioralnych świadczących o chronicznym stresie psów, które są wspólne dla wszystkich przedstawicieli tego gatunku, jednak nie zawsze wszystkie występują jednocześnie [Beerda i in. 1997]. W zależności od indywidualnych cech osobnika mogą być również przejawiane $\mathrm{z}$ odmienną intensywnością. Należą do nich m.in.: natężenie wokalizacji, przyjmowanie niskiej/ ulgowej postawy, tulenie uszu i ogona, zjadanie odchodów, zwiększona samopielęgnacja, częste powtarzanie tych samych czynności (stereotypia) [Fuller 1967]. Często obserwowane są także zaburzenia snu, zaburzenie funkcji poznawczych, brak skupienia i uwagi, trudności w nauce. Ponadto, ograniczenie kontaktów socjalnych czy ubogie w bodźce środowisko mogą modyfikować zachowanie psów, powodując u jednych nadmierne reakcje pobudzenia i ekscy- 
tacji, np. merdanie ogonem, wąchanie, kręcenie się w kółko, oddawanie moczu i kału, zwiększona ogólna lokomocja, a u innych zachowania związane $\mathrm{z}$ agresja czy dominacją, takie jak nastroszenie sierści, warczenie, kładzenie łap na innych osobnikach [Olczak i in. 2014]. Jeszcze inne psy stają się w takich warunkach bardzo niepewne, wręcz bojaźliwe czy lękliwe, skłonne do ucieczki [Beerda i in. 1999].

Do materiału biologicznego wykorzystywanego do pomiaru natężenia reakcji stresowej u psów zaliczamy surowicę, ślinę, mocz i kał oraz włosy. Surowicę, ślinę i mocz wykorzystuje się do określania natężenia stresu ostrego, otrzymane wartości porównuje się z wartościami referencyjnymi, które dla surowicy wynoszą 1-6 ug/dl. Włosy i kał są pobierane w celu oceny stresu przewlekłego na postawie oznaczeń stężenia metabolitów kortyzolu, m.in. metabolitu 11,17-dioksoandrostanu (DOA). Coraz częściej naukowcy wykorzystują zamiennie ślinę i mocz, aby oszczędzić psom stresu związanego z inwazyjnym pobraniem od nich krwi (fot. 1 i 2). Wartości kortyzolu w tych materiałach biologicznych wykazują ścisłą korelację, dlatego mogą być używane naprzemiennie [Bhagwagar $i$ in. 2002]. Najczęściej stosowanymi metodami analitycznymi pozwalającymi na ilościowe oznaczenie poziomu kortyzolu w organizmie są metody immunochemiczne oraz radioimmunologiczne [Dziurkowska i Wesołowski 2010]. Charakteryzują się dużą czułością oraz niewielką ilością materiału potrzebnego do oznaczeń ( $1 \mathrm{ml})$. Accorsi i in. [2008] badali przy pomocy testu Elisa kortyzol we włosach i kale u psa domowego. Otrzymane w badaniu dane pokazują, że $\mathrm{w}$ obu materiałach istniała znacząca dodatnia korelacja w poziomie kortyzolu.

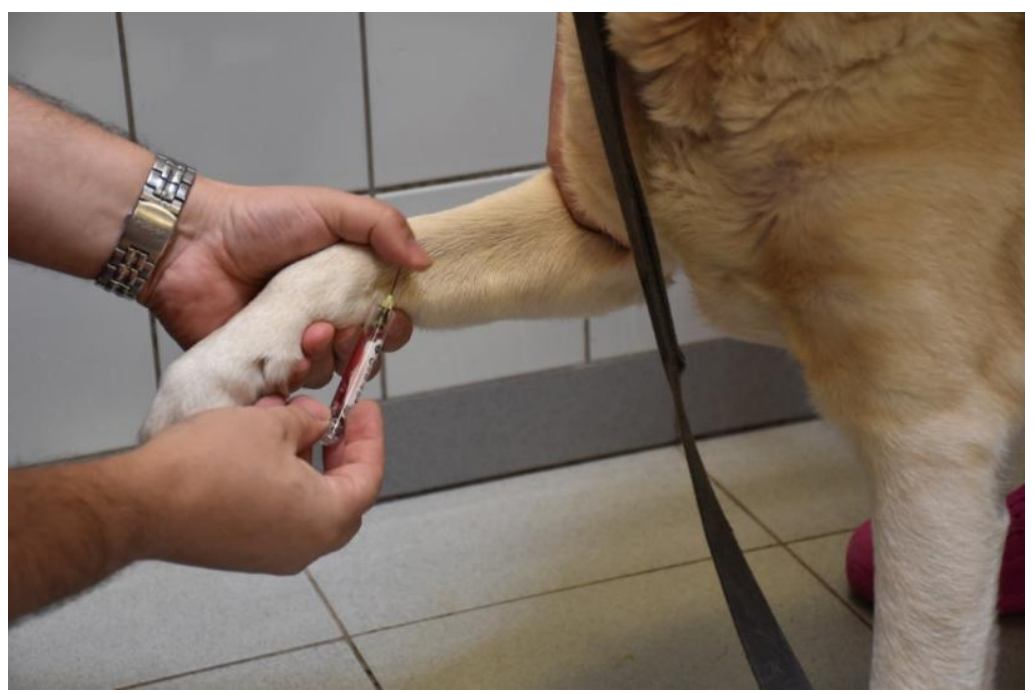

Fot. 1. Pobieranie krwi od psa (fot. A. Garbiec) 


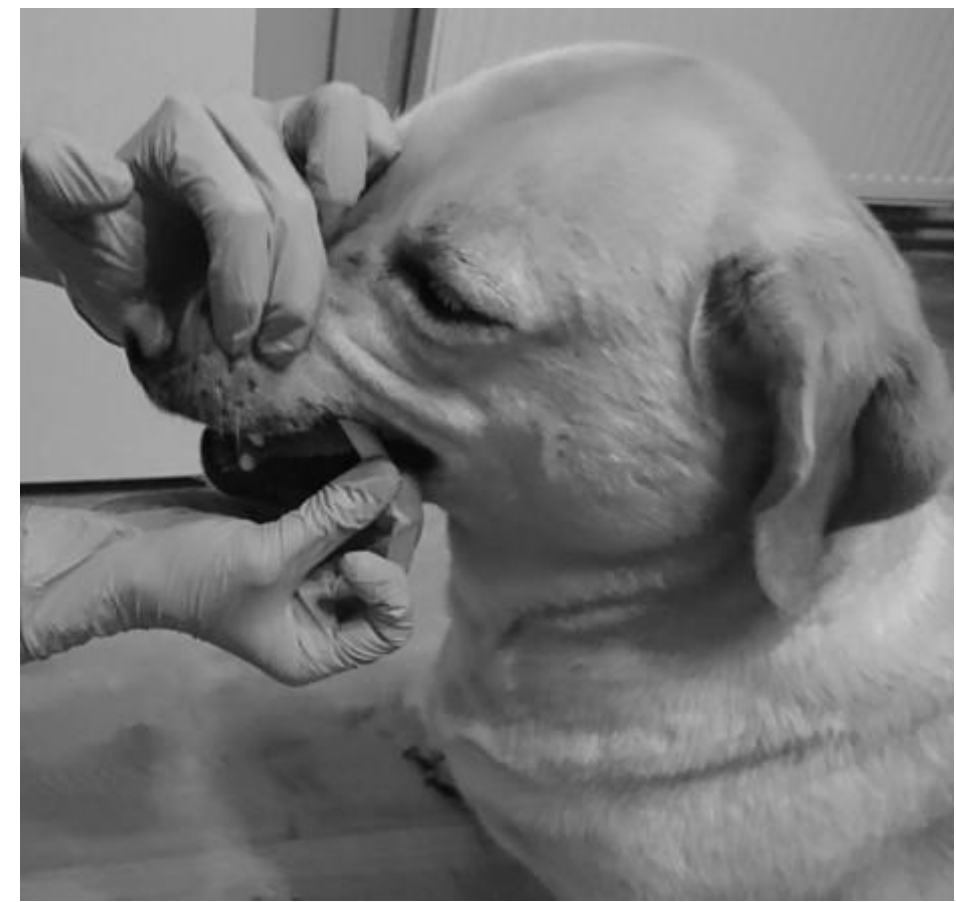

Fot. 2. Pobieranie śliny od psa (fot. J. Wojtaś)

W celu łagodzenia reakcji stresowej można stosować metody terapeutyczne oraz farmakologiczne. Do najczęstszych metod zaliczamy terapię behawioralną indywidualną lub grupową, polegającą na odczulaniu na konkretne bodźce. Stopniowe konfrontowanie ze stresorem warto połączyć z pozytywnym wzmocnieniem. W terapii bardzo pomocna jest obecność opiekuna, jego spokój i zaangażowanie. Coraz popularniejsza staje się feromonoterapia $\mathrm{w}$ celu łagodzenia skutków stresu związanego $\mathrm{z}$ nieznanym otoczeniem czy nawiązywaniem nowych relacji. Powszechnie stosowane i uznane za bezpieczne są ziołowe substancje o działaniu uspokajającym, np. waleriana, melisa czy tryptofan.

Znajomość związku między poziomem kortyzolu, relacjami społecznymi, sygnałami świadczącymi o stresie a osobowoścą psów pozwoli na szerokie i kompleksowe analizowanie ich zachowań. Zrozumienie tych zależności ma szczególne znaczenie w odniesieniu do stresu przewlekłego, który ma bardzo niekorzystny wpływ na organizm prowadzący do zaburzeń zachowania i niskiego wskaźnika dobrostanu, a tym samym nasilenia skłonności do chorób metabolicznych na tle zaburzeń hormonalnych. 


\section{Bibliografia}

Accorsi P., Carloni E., Valsecchi P., Viggiani R., Gamberoni M., Tamanini C., Seren E., 2008. Cortisol determination in hair and faeces from domestic cats and dogs. Gen. Comp. Endocrinol. 155, 398-402.

Beerda B., Schilder M.B., Bernadina W., Hooff J. van, Vries H.W. de, Mol J., 1999. Chronic stress in dogs subjected to social and spatial restriction. II. Hormonal and immunological responses. Physiol. Behav. 66(2), 243-54.

Beerda B., Schilder M.B., Hooff J. van, Vries H.W de, 1997. Manifestations of chronic and acute stress in dogs. Appl. Anim. Behav. Sci. 52, 307-319.

Beerda B., Schilder M.B., Hooff J.A. van, Vries H.W. de, Mol J.A., 2000. Behavioural and hormonal indicators of enduring environmental stress in dogs. Anim. Welfare 9, 49-62.

Bhagwagar Z., Hafizi S., Cowen P.J., 2002. Acute citalopram administration produces correlated increases in plasma and salivary cortisol. Psychopharmacology 163, 118-120.

Davenport G.M., Hicks T.A., McGlone J.J., Whisnant C.S., Kattesh H.G., Norman R.L., 1998. Behavioral, endocrine, immune and performance measures for pigs exposed to acute stress. J. Anim. Sci. 76, 474-483.

Dziurkowska E., Wesołowski M., 2010. Saliva - the valuable biological material for cortisol determination. Farm. Przegl. Nauk. 12, 21-26.

Fuller J.L., 1967. Experimental deprivation and later behavior: Stress of emergence is postulated as the basis for behavioral deficits seen in dogs following isolation. Science 158(3809), 1645-1652.

Hennessy M.B., Davis H.N., Williams M.T., Mellott C., Douglas C.W., 1997. Plasma cortisol levels of dogs at a county animal shelter. Physiol. Behav. 62(3), 485-490.

Landowski J., 2007. Neurobiology of stress. Neuropsychiatr. Neuropsychol. 2(1), 26.

Marć-Pieńkowska J., Topolińska P., Mitura K., 2014. Poziom stresu wskaźnikiem dobrostanu zwierząt. Wiad. Zootech. 52(2), 36-42.

Moberg G.P., Mench J.A., 2000. The Biology of Animal Stress. Basic Principlesand Implications for Animal Welfare CAB International.

Olczak K., Petrynka M., Małopolska M., Klocek C., 2014. Reakcje stresowe u psów i ich biologiczne uwarunkowania. Czasopismo Naukowo-Kulturalne 1, 237-244.

Ottenheimer Carrier L., Cyr A., Anderson R.E., Walsh C.J., 2013. Exploring the dog park: Relationships between social behaviours, personality and cortisol in companion dogs. Appl. Anim. Behav. Sci. 146(1-4), 96-106.

Pyrczek T., Stefaniak T., 2013. Wykorzystanie oznaczania kortyzolu i jego pochodnych w ocenie stresu u psów służbowych. Życie Wet. 88(2), 136-141.

Rooney N.J., Gaines S.A., Bradshaw J.W., 2007. Behavioural and glucocorticoid responses of dogs (Canis familiaris) to kennelling: investigating mitigation of stress by prior habituation. Physiol. Behav. 92(5), 847-854.

Sadowski B., 2001. Biologiczne mechanizmy zachowania się ludzi i zwierząt. PWN, Warszawa, $466-520$.

Skórzewska A., Zienowicz M., Lehner M., Wisłowska A., Maciejak P., Szyndler J., Płaźniak A., 2004. Regulacja osi podwzgórzowo-przysadkowo-nadnerczowej w reakcjach stresowych. Post. Psychiatr. Neurol. 13(3), 235-246. 
Wiktoria Janicka ${ }^{1}$, Wanda Krupa ${ }^{2}$

\title{
Optymalizacja warunków utrzymania koni w kontekście możliwości prezentowania naturalnych zachowań
}

\author{
Optimisation of the horse keeping conditions in the context of the possibility to present natural \\ behaviour
}

Ewolucja koni, która rozpoczęła się już $65 \mathrm{mln}$ lat temu, doprowadziła do wykształcenia i utrwalenia określonych zachowań warunkujących ich przetrwanie w naturalnym środowisku [Waran 2002]. Pomimo domestykacji oraz konieczności dostosowania się do warunków stworzonych przez człowieka, reaktywność behawioralna nieparzystokopytnych praktycznie nie uległa zmianie [Christensen i in. 2002b, Heleski i in. 2002]. Equus caballus jest zwierzęciem stepowym, stadnym i uciekającym [Zeitler-Feicht 2014]. Przebywanie w grupie społecznej czy przemieszczanie się połączone z pobieraniem pokarmu stanowią wrodzone potrzeby konia i powinny być uwzględniane we wszystkich systemach jego utrzymywania [Sarrafchi i Blokhuis 2013]. Jak podkreślają różni autorzy, swobodne prezentowanie behawioru socjalnego, pokarmowego i lokomotorycznego jest istotnym czynnikiem minimalizującym ryzyko pojawienia się zachowań nietypowych i pozwalającym na zachowanie równowagi emocjonalnej [Visser i Van Wijk-Jansen 2012, Kozak i Budzyńska 2017]. Poziom dobrostanu koni utrzymywanych przez człowieka w głównej mierze zależy od wiedzy opiekunów, ich relacji ze zwierzętami czy sposobu zarządzania stajnią [Hötzel i in. 2019, Thompson i Clarkson 2019]. Współcześnie, najbliższy warunków życia dzikich przodków jest system hodowli rezerwatowej. Nieparzystokopytne cały rok wypasają się na wielohektarowych pastwiskach i polanach, dostosowując swoją aktywność do zasobności siedliska i pogody [Jaworski i in. 2018]. Istnieje jednak możliwość wypracowania kompromisu pomiędzy utrzymywaniem koni w tradycyjnych oraz seminaturalnych systemach chowu i hodowli. Kluczowe jest podejmowanie działań uwzględniających behawioralne potrzeby nieparzystokopytnych oraz stosowanie wzbogaceń odzwierciedlających naturalny habitat koni [Goodwin i in. 2002, Søndergaard i in. 2011]. Dobrym rozwiązaniem będzie zaprojektowanie systemu ścieżek z oddalonymi od siebie obszarami funk-

\footnotetext{
1 Uniwersytet Przyrodniczy w Lublinie, Wydział Nauk o Zwierzętach i Biogospodarki, Studenckie Koło Naukowe Nauk o Zwierzętach i Biogospodarki - Sekcja Behawiorystyki Zwierząt,wiktoria.janicka1995@gmail.com

2 Uniwersytet Przyrodniczy w Lublinie, Wydział Nauk o Zwierzętach i Biogospodarki, Katedra Etologii Zwierząt i Łowiectwa
} 
cyjnymi, a więc stworzenie swoistej aktywnej stajni, znanej jako Paddock Paradise [Willis i Jackson 2012].

\section{Gatunkowy wzorzec behawioralny}

Zamieszkiwanie otwartej przestrzeni oraz pozycja zajmowana $\mathrm{w}$ łańcuchu troficznym wiązały się $\mathrm{w}$ przypadku koni $\mathrm{z}$ koniecznością stałego przebywania w stadzie [Fureix i in. 2012]. Samotnie wędrujące osobniki są rzadkością. Zdarza się, że nawet doświadczone ogiery, które utraciły swój harem starają się dołączyć do grup kawalerskich. Takie zachowanie dowodzi silnie rozwiniętego instynktu stadnego i powinno być uwzględniane w hodowli czy w ośrodkach jeździeckich [Christensen i in. 2002a]. Życie w grupie o ustabilizowanej hierarchii niesie wiele korzyści. Możliwość swobodnej komunikacji ułatwia wykrycie potencjalnego niebezpieczeństwa i pozwala na skuteczną obronę. Jednocześnie skróceniu ulega czas czuwania poszczególnych członków stada, dzięki czemu zwierzęta mogą dłużej żerować czy odpoczywać [Zeitler-Feicht 2014]. Młode osobniki, obserwując starsze, uczą się zachowań typowych dla gatunku. Przygotowują się w ten sposób do pełnienia określonych ról i poznają sposoby unikania zagrożenia [Bourjade i in. 2008]. Ponadto okazja do zabawy z rówieśnikami wzbogaca społeczne życie zwierząt, a przepychanki i pozorowane walki dają ogierkom szansę na praktykowanie umiejętności potrzebnych do zdobycia w przyszłości własnych klaczy [Zeitler-Feicht 2014]. Przebywanie w stadzie umożliwia zaspokojenie wrodzonych popędów i ściśle wiąże się z prezentowaniem innych czynności, stanowiących w pewnym zakresie składowe behawioru społecznego.

Konie wypasają się, wędrują do źródeł pokarmu i wody oraz odpoczywają w grupie [Fiedorowicz i Łojek 2004]. Oprócz indywidualnych zachowań komfortowych, takich jak drapanie się i ocieranie o obiekty, u domowych nieparzystokopytnych występuje też pielęgnacja społeczna. Ma ona decydujące znaczenie $\mathrm{w}$ budowaniu i wzmacnianiu więzi międzyosobniczych oraz $\mathrm{w}$ obniżaniu napięcia [Feh i Mazières 1993]. Konie są zwierzętami o wysoko rozwiniętym instynkcie społecznym, dlatego też deprywacja socjalna jest dla nich wyjątkowo silnym stresorem [Hartmann $i$ in. 2012].

Podobnie jak izolacja, również błędy żywieniowe skutkują obniżeniem dobrostanu domowych nieparzystokopytnych. Szczególnie dotkliwe dla nich jest ograniczenie dostępu do paszy objętościowej, ponieważ Equuscaballus jest przystosowany do powolnego, długotrwałego pobierania pokarmu. Na wolności konie pasą się nawet przez 16-20 godzin w ciągu doby. Zbyt krótki czas poświęcany na jedzenie prowadzi do nudy, frustracji i w konsekwencji do rozwoju problemów behawioralnych [Sarrafchi i Blokhuis 2013]. Zwierzęta te charakteryzuje specyficzny wzorzec odżywiania. Pobierają niewielką ilość pokarmu, a następnie przemieszczają się o kilka kroków do nowej „stacji żywieniowej” [Berg i in. 2015]. Takie postępowanie umożliwia wybór najbardziej atrakcyjnego 
źródła roślinności, w zależności od indywidualnych preferencji i aktualnego zapotrzebowania energetycznego [Goodwin i in. 2005]. Z poszukiwaniem pożywienia nieodłącznie związana jest lokomocja. Konie w trakcie żerowania poruszają się spokojnym stępem, wykonując ponad 10 tys. kroków dziennie [Sarrafchi i Blokhuis 2013]. Jest to także podstawowy chód w czasie dłuższych wędrówek. Kłus i galop pojawiają się zdecydowanie rzadziej, głównie podczas zabawy, zalotów czy ucieczki [Lee i in. 2011, Werhahn i in. 2011]. Nieparzystokopytne żyjące na wolności pokonują w ciągu doby nawet $17 \mathrm{~km}$, choć $\mathrm{z}$ reguły dystans ten nie przekracza $6 \mathrm{~km}$. Odległość, jaką przemierzają, zależy od dostępności pokarmu, wody, położenia miejsc wypoczynku oraz pogody. Konie posiadają dużą zdolność adaptacji do zmieniających się warunków otoczenia [Pirkelmann i in. 2010]. Aktywność lokomotoryczna wywiera korzystny wpływ na zdrowie zwierząt. Poprawia równowagę, wspomaga prawidłowy rozwój stawów, mięśni i ścięgien oraz wzmacnia kopyta. Stworzenie koniom możliwości swobodnego poruszania się sprzyja utrzymaniu ich we właściwej kondycji psychicznej i fizycznej [Kurvers i in. 2006].

\section{Ograniczenie swobodnego przejawiania naturalnych zachowań}

Pomimo wielowiekowej koegzystencji z ludźmi, konieczności dostosowania się do warunków przez nich stworzonych oraz powstałych w wyniku domestykacji cech udomowieniowych, gatunkowy wzorzec behawioralny domowych nieparzystokopytnych nie odbiega znacząco od prezentowanego przez dzikich przodków [Christensen i in. 2002b, Heleski i in. 2002]. Konie potrzebują życia w grupie dającej poczucie bezpieczeństwa i pozwalającej na nawiązywanie interakcji międzyosobniczych. Zdecydowaną część doby wolno żyjących przedstawicieli gatunku zajmuje pasienie się, dlatego niezbędne jest zapewnienie zwierzętom wielogodzinnego dostępu do pastwisk i wybiegów oraz paszy objętościowej. Nieuwzględnianie tych potrzeb skutkuje obniżeniem dobrostanu koni oraz utrudnia ich obsługę i użytkowanie [Sarrafchi i Blokhuis 2013]. Deklarowana przez opiekunów znajomość ogólnej reaktywności behawioralnej gatunku często nie znajduje odzwierciedlenia w praktyce. Ponad $75 \%$ koni w Europie jest utrzymywanych w odosobnieniu i spędza większość doby w boksie [Visser i Van Wijk-Jansen 2012]. Właściciele obawiają się kontuzji i urazów mogących wystąpić podczas grupowego padokowania. Uniemożliwiłyby one treningi i udział w zawodach [Fureix in. 2012]. Popularny jest również pogląd głoszący, że zwierzęta wypuszczane na wybiegi zużywają energię niezbędną do efektywnego użytkowania. Tymczasem Werhahn i in. [2012] dowiedli, że konie mające możliwość swobodnego ruchu na świeżym powietrzu współpracują z człowiekiem chętniej niż zwierzęta pozbawione dostępu do padoków. Ponadto osobniki nieprzebywające na wybiegach zdradzały w trakcie pracy objawy silniejszego stresu, a w stajni były bardziej niespokojne. Zatem pozbawienie możliwości realiza- 
cji behawioru lokomotorycznego może skutkować zranieniami o elementy boksu oraz zmniejszeniem wydajności treningu. Badacze donoszą również o osiąganiu lepszych wyników szkolenia w przypadku grupowego padokowania zwierząt. Biorąc pod uwagę fakt, że izolacja jest silnym stresorem, należy stworzyć koniom przebywającym na wybiegu jak najbardziej socjalne środowisko. $\mathrm{W}$ indywidualnym systemie utrzymania często jest to jedyna sposobność do nawiązywania bezpośrednich interakcji społecznych. Nieparzystokopytne pozbawione możliwości komunikacji z innymi przedstawicielami gatunku są szczególnie narażone na rozwój anomalii behawioralnych [Zeitler-Feicht 2014]. Wielogodzinne unieruchomienie sprawia, że zwierzęta nie mogą właściwie spożytkować energii i szukają zachowań zastępczych, takich jak tkanie czy krążenie po boksie. Pojawiają się też zachowania niepożądane zmniejszające bezpieczeństwo podczas obsługi i użytkowania nieparzystokopytnych [Sarrafchi i Blokhuis 2013]. Ograniczenie ruchu wiąże się ponadto $\mathrm{z}$ większym ryzykiem rozwoju chorób układu mięśniowo-szkieletowego [Werhahn i in. 2011]. Błędnie zaprojektowane budynki stajenne, nieuwzględniające minimalnych wymagań techniczno-technologicznych, istotnie naruszają homeostazę organizmu. Zbyt mała powierzchnia boksów i stanowisk utrudnia naturalne kładzenie się i wstawanie, dlatego może być przyczyną urazów i narastającej frustracji [Zeitler-Feicht 2014]. Obecnie dominuje model skoncentrowanego żywienia koni. Monodieta, duży udział pasz treściwych i niedobór pasz objętościowych wypełniających żołądek są dalekie od naturalnego wzorca odżywiania Equuscaballus. Zadawanie pokarmu do żłobów sprawia, że zwierzęta nie muszą poruszać się w celu jego zdobycia, a czas jedzenia jest zbyt krótki. W efekcie zwierzęta zaczynaja się nudzić, a to prowadzi do stereotypii oralnych i motorycznych. Okazuje się, że wraz ze spadkiem zawartości włókna w dawce pokarmowej wzrasta tendencja do żucia drewna [Fiedorowicz i Łojek 2004]. Zaobserwowanie tego typu zaburzeń jest sygnałem wskazującym na konieczność interwencji i wyeliminowania nieprawidłowości w środowisku życia koni [Berg i in. 2015]. Dieta uboga w paszę objętościową może skutkować też zaburzeniami ze strony przewodu pokarmowego, takimi jak owrzodzenie żołądka oraz kolka [Rochais i in. 2018]. Wyzwaniem dla hodowców i opiekunów koni jest stworzenie warunków gwarantujących wysoki poziom dobrostanu, ze szczególnym uwzględnieniem aspektu emocjonalnego [Green i Mellor 2011].

\section{Ksztaltowanie dobrostanu koni w różnych systemach utrzymania}

Systemem, który w największym stopniu odzwierciedla naturalne środowisko życia uciekających roślinożerców, jest hodowla rezerwatowa. Konie przez cały rok przebywają na pastwiskach, łąkach i w lasach w otoczeniu innych zwierząt. Ingerencja człowieka ogranicza się do monitorowania zdrowia stada, dokarmiania sianem w zimie oraz do prowadzenia pracy hodowlanej. Nieparzysto- 
kopytne żyją w jednym lub kilku tabunach, przejawiając szeroki zakres zachowań społecznych [Jaworski i in. 2018]. Rozległe i zróżnicowane tereny sprzyjają wielogodzinnemu wypasaniu i poszukiwaniu schronienia w przypadku niekorzystnej pogody. Konie korzystają z naturalnych ujęć wody i zasobności siedliska, dostosowując aktywność dobową do czynników endo- i egzogennych [Olczak i Klocek 2013, Berg i in. 2015]. Jednak z uwagi na bardzo dobrze rozwinięty przemysł jeździecki, dostępną powierzchnię czy choćby charakterystykę pewnych ras niemożliwe jest utrzymywanie wszystkich koni w warunkach rezerwatowych [Hötzel i in. 2019]. Konieczne jest więc podejmowanie działań zmierzających do realizacji założeń pięciodomenowego modelu dobrostanu [Green i Mellor 2011]. Wyróżnia się dwa podstawowe systemy chowu i hodowli nieparzystokopytnych: indywidualny (stanowisko, boks) i grupowy (biegalnia, otwarta stajnia). W tabeli 1 porównano cztery możliwe sposoby utrzymywania koni.

Tabela 1. Porównanie systemów utrzymania koni z wykorzystaniem 4-punktowej skali własnej, gdzie 1 oznacza najniższą, a 4 najwyższą ocenę [opracowano na podstawie: Fiedorowicz i Łojek 2004]

\begin{tabular}{|l|c|c|c|c|}
\hline \multirow{2}{*}{\multicolumn{1}{|c|}{ Czynnik }} & \multicolumn{4}{c|}{ System utrzymania } \\
\cline { 2 - 5 } & stanowisko & boks & biegalnia & $\begin{array}{c}\text { otwarta } \\
\text { stajnia }\end{array}$ \\
\hline $\begin{array}{l}\text { Możliwość nawiązywania } \\
\text { interakcji społecznych }\end{array}$ & 1 & 2 & 3 & 4 \\
Swoboda ruchu & 1 & 2 & 3 & 4 \\
Stymulacja sensoryczna & 1 & 2 & 3 & 4 \\
Monitorowanie stanu zdrowia & 4 & 4 & 2 & 1 \\
Kontrola karmienia & 4 & 4 & 2 & 1 \\
Dostęp do konia & 4 & 4 & 2 & 1 \\
\hline
\end{tabular}

Utrzymanie indywidualne jest korzystne jedynie z punktu widzenia człowieka. Bezpośredni dostęp do zwierząt oraz łatwość kontrolowania zjadania paszy i monitorowania stanu zdrowia sprzyjają intensywnemu użytkowaniu nieparzystokopytnych. Jednak grupowy chów w większym stopniu pozwala na realizację wrodzonych potrzeb koni [Fiedorowicz i Łojek 2004]. Dla zwierząt stadnych niezwykle istotna jest komunikacja $\mathrm{z}$ innymi osobnikami. Możliwość swobodnego poruszania się ogranicza nudę oraz pozwala na wybór miejsca do wypoczynku, naturalne kładzenie się i wstawanie. Różnorodność środowiska i występujących w nim bodźców redukuje ryzyko poszukiwania czynności zastępczych [Pirkelmann i in. 2010]. O pozytywnym wpływie chowu grupowego na dobrostan koni donoszą Visser i in. [2008]. Młode zwierzęta, które po przeniesieniu $\mathrm{z}$ biegalni lub otwartej stajni połączono w pary, wykazywały zdecydowanie słabsze oznaki stresu niż osobniki umieszczone w indywidualnych boksach. Søndergaard i Ladewig [2004] dodają, że życie w socjalnym środowisku oraz zaspokojenie instynktu stadnego korzystnie oddziałują na proces nauki, wzrost 
efektywności treningu i bezpieczeństwa podczas obsługi zwierząt. Søndergaard $\mathrm{i}$ in. [2011] podkreślają jak ważne jest zapewnienie nieparzystokopytnym możliwości nawiązywania bezpośrednich interakcji społecznych. Kiedy alternatywą jest całkowita izolacja, konie wybierają przynajmniej ograniczony kontakt fizyczny z innymi osobnikami - przez dotyk głowami lub nozdrzami. Projektując budynek stajenny, należy więc uwzględnić wzbogacenia socjalne. Jako uciekający roślinożerca Equus caballus jest przystosowany do powolnego, wielogodzinnego wędrowania i poszukiwania pokarmu [Berg i in. 2015]. Utrzymanie wysokiego poziomu dobrostanu $\mathrm{w}$ tradycyjnym chowie stajennym będzie wiązało się z wydłużeniem czasu spędzanego na pastwisku, co ważne, w towarzystwie pozostałych członków stada. Lee i in. [2011] wykazali, że motywacja koni do podjęcia aktywności wzrasta, gdy na padoku przebywają one $\mathrm{w}$ grupie. Ze względu na znaczenie lokomocji w prewencji chorób aparatu ruchu i rozwoju stereotypii warto rozważyć grupowe padokowanie. Jeśli jednak obawy opiekunów przed agresywnymi starciami zwierząt są duże lub z różnych przyczyn niemożliwe jest wypuszczanie zwierząt całym stadem, dobrym wyjściem okazuje się wyprowadzanie koni parami [Janczarek i in. 2019]. Odpowiedzią na wrodzoną potrzebę długotrwałego pobierania pokarmu, oprócz dostępu do pastwisk, są różnego rodzaju rozwiązania spowalniające jedzenie. Rochais i in. [2018] donoszą o skuteczności siatek na siano oraz pojemników ze specjalną kratką. Podstawą działania $\mathrm{w}$ eliminowaniu anomalii behawioralnych jest zwiększenie udziału paszy objętościowej $\mathrm{w}$ dawce pokarmowej. Jeśli padoki pozbawione są trawy, siano powinno być dostarczane również osobnikom przebywającym na wybiegu. Spowodowana bezczynnością nuda może skutkować zjadaniem ziemi, wylizywaniem ogrodzenia czy obgryzaniem kory [Zeitler-Feicht 2014]. Nieparzystokopytne żyjące na wolności spożywają nawet kilkadziesiąt różnych gatunków roślin [Berg i in. 2015]. Goodwin i in. [2002] proponują dostarczanie koniom kilku rodzajów pasz objętościowych jednocześnie. Zastosowany efekt nowości i selektywne pobieranie pokarmu odwzorowują naturalny wzorzec odżywania oraz zmniejszają udział zachowań nietypowych w aktywności dobowej zwierząt. Alternatywą dla hodowli rezerwatowej jest Paddock Paradise stanowiący kompromis między utrzymaniem koni $\mathrm{w}$ warunkach seminaturalnych i tradycyjnych. Nieparzystokopytne mają do dyspozycji wiatę lub otwartą stajnię oraz system ścieżek o zróżnicowanej szerokości. Na terenie takiego padoku znajdują się oddalone od siebie obszary funkcyjne, takie jak wodopój, strefy odpoczynku oraz żywienia. Odpowiednie rozwiązania znacząco wydłużają pasienie się, a strategiczne rozmieszczenie poszczególnych punktów oraz obecność innych osobników motywują zwierzęta do przemieszczania się. Zastosowanie szeregu wzbogaceń środowiskowych pozwala na swobodne przejawianie behawioru społecznego, pokarmowego i lokomotorycznego [Willis i Jackson 2012].

Człowiek, podejmując się udomowienia zwierząt, wziął na siebie odpowiedzialność za ich zdrowie, poczucie bezpieczeństwa i komfortu. Od jego wiedzy i postępowania zależy poziom dobrostanu nieparzystokopytnych. Kluczowe jest 
więc stworzenie warunków pozwalających koniom na naturalne dla nich zachowania [Kozak i Budzyńska 2017, Thompson i Clarkson 2019].

\section{Bibliografia}

Berg M. van den, Brown W.Y., Lee C., Hinch G.N., 2015. Browse-related behaviors of pastured horses in Australia: A survey. J. Vet. Behav. 10, 48-53.

Bourjade M., Moulinot M., Henry S., Richard-Yris M.-A., Hausberger M., 2008. Could Adults be Used to Improve Social Skills of Young Horses, Equus caballus? Dev. Psychobiol. 50, 408-417.

Christensen J.W., Ladewig J., Søndergaard E., Malmkvist J., 2002a. Effects of individual versus group stabling on social behaviour in domestic stallions. Appl. Anim. Behav. Sci. 75, 233-248.

Christensen J.W., Zharkikh T., Ladewig J., Yasinetskaya N., 2002b. Social behavior in stallion groups (Equus przewalskii and Equus caballus) kept under natural and domestic conditions. Appl. Anim. Behav. Sci. 76, 11-20.

Feh C., Mazières J. de, 1993. Grooming at a preferred site reduces heart rate in horses. Anim. Behav. 46, 1191-1194.

Fiedorowicz G., Łojek J., 2004. Systemy utrzymania koni. Poradnik. Instytut Budownictwa, Mechanizacji i Elektryfikacji Rolnictwa, Warszawa.

Fureix C., Bourjade M., Henry S., Sankey C., Hausberger M., 2012. Exploring aggression regulation in managed groups of horses Equus caballus. Appl. Anim. Behav. Sci. 138, 216-228.

Goodwin D., Davidson H.P.B., Harris P., 2002. Foraging enrichment for stabled horses: effects on behavior and selection. Equine Vet. J. 34(7), 686-691.

Goodwin D., Davidson H.P.B., Harris P., 2005. Sensory varieties in concentrate diets for stabled horses: effects on behaviour and selection. Appl. Anim. Behav. Sci. 90, 337-349.

Green T.C., Mellor D.J., 2011. Extending ideas about animal welfare assessment to include 'quality of life' and related concepts. N. Z. Vet. J. 59(6), 263-271.

Hartmann E., Søndergaard E., Keeling L.J., 2012. Keeping horses in groups: A review. Appl. Anim. Behav. Sci. 136, 77-87.

Heleski C.R., Shelle A.C., Nielsen B.D., Zanella A.J., 2002. Influence of housing on weanling horse behavior and subsequent welfare. Appl. Anim. Behav. Sci. 78, 291-302.

Hötzel M.J., Vieira M.C., Leme D.P., 2019. Exploring horse owners' and caretakers' perceptions of emotions and associated behaviors in horses. J. Vet. Behav. 29, 18-24.

Janczarek I., Wiśniewska M., Wilk I., Liss M., Wnuk-Pawlak E., Dybczyńska M., 2019. Ocena zachowań afiliacyjnych wśród klaczy. Rocz. Nauk. PTZ 15(2), 49-58.

Jaworski Z., Jastrzębska E., Górecka-Bruzda A., 2018. Wypas koników polskich na terenach cennych przyrodniczo - kształtowanie krajobrazu i zachowanie bioróżnorodności. Prz. Hod. 5, $20-24$.

Kozak A., Budzyńska M., 2007. Interakcje człowiek - zwierzę w aspekcie dobrostanu i użytkowania koni. Wiad. Zootech. 55(1), 94-100.

Kurvers C.M.H.C., Weeren P.R. van, Rogers C.W., Dierendonck M.C. van, 2006. Quantification of spontaneous locomotion activity in foals kept in pastures under various management conditions. Am. J. Vet. Res. 67(7), 1212-1217.

Lee J., Floyd T., Erb H., Houpt K., 2011. Preference and demand for exercise in stabled horses. Appl. Anim. Behav. Sci. 130, 91-100.

Olczak K., Klocek C., 2013. Wpływ wybranych zjawisk atmosferycznych na zachowanie koni. Med. Wet. 69(10), 602-605.

Pirkelmann H., Ahlswede L., Zeitler-Feicht M., 2010. Hodowla koni. Organizacja stajni i żywienie. RM, Warszawa.

Rochais C., Henry S., Hausberger M., 2018. "Hay-bags" and "Slow feeders": Testing their impact on horse behaviour and welfare. Appl. Anim. Behav. Sci. 198, 52-59. 
Sarrafchi A., Blokhuis H.J., 2013. Equine stereotypic behaviors: Causation, occurrence, and prevention. J. Vet. Behav. 8, 386-394.

Søndergaard E., Jensen M.B., Nicol H.J., 2011. Motivation for social contact in horses measured by operant conditioning. Appl. Anim. Behav. Sci. 132, 131-137.

Søndergaard E., Ladewig J., 2004. Group housing exerts a positive effect on the behaviour of young horses during training. Appl. Anim. Behav. Sci. 87, 105-118.

Thompson K., Clarkson L., 2019. How owners determine if the social and behavioral needs of their horses are being met: Findings from an Australian online survey. J. Vet. Behav. 29, 128-133.

Visser E.K., Ellis A.D., Reenen C.G. van, 2008. The effect of two different housing conditions on the welfare of young horses stabled for the first time. Appl. Anim. Behav. Sci. 114, 521-533.

Visser E.K., Van Wijk-Jansen E.E.C., 2002. Diversity in horse enthusiasts with respect to horse welfare: An explorative study. J. Vet. Behav. 7, 295-304.

Waran N., 2002. The Welfare of Horses. KAP, Dordrecht.

Werhahn H., Hessel E.F., Schulze H., Weghe H.F.A. van den, 2011. Temporary Turnout for Free Exercise in Groups: Effects on the Behavior of Competition Horses Housed in Single Stalls. J. Equine. Vet. Sci. 31, 417-425.

Werhahn H., Hessel E.F., Weghe H.F.A. van den, 2012. Competition Horses Housed in Single Stalls (II): Effects of Free Exercise on the Behavior in the Stable, the Behavior during Training, and the Degree of Stress. J. Equine. Vet. Sci. 32, 22-31.

Willis J., Jackson J., 2012. Creating Paradise. Equine Welness 7(4), 56-58.

Zeitler-Feicht M.H., 2014. Zachowania koni. Przyczyny, terapia i profilaktyka. Świadome Jeździectwo, Warszawa. 
Paweł Jurczak ${ }^{1,2}$, Anna Polz ${ }^{1}$, Zuzanna Całyniuk ${ }^{1}$, Patrycja Cieplińska ${ }^{1}$, Marcin Kiewlak ${ }^{1}$, Agnieszka Serek ${ }^{1}$, Ewelina Cholewińska ${ }^{1}$, Katarzyna Ognik ${ }^{1}$

\title{
Badanie wpływu barbituranów jako substancji wykorzystywanych w eutanazji na stopień indukcji stresu oksydacyjnego w organizmie psa
}

\author{
Research on the effect of barbiturates as substances used in euthanasia on the degree \\ of infuction of oxidative stress in the dog's body
}

Barbiturany to grupa leków, które działają depresyjnie na ośrodkowy układ nerwowy, a przez to mogą wywoływać szeroki zakres efektów od łagodnej sedacji po śmierć. Barbiturany są skuteczne jako środki przeciwlękowe, nasenne i przeciwdrgawkowe, ale mogą uzależniać fizycznie i psychicznie. Związki te są pochodnymi kwasu barbiturowego. Barbiturany, które posiadają przy drugim atomie węgla atom tlenu, są nazywane oksybarbituranami, natomiast pochodne, które przy tym samym atomie węgla posiadają atom siarki to tiobarbiturany. Te ostatnie są dobrze rozpuszczalne w tłuszczach (lepiej niż oksybarbiturany). Lepsza rozpuszczalność w lipidach powoduje przyspieszenie rezultatów, skraca czas działania, przyspiesza szybkość rozkładu i prawdopodobnie poprawia siłę działania nasennego [Larsen 2013].

Barbiturany w dużych dawkach są stosowane w samobójstwach wspomaganych przez lekarza oraz w połączeniu z lekiem zwiotczającym mięśnie w eutanazji i karach śmierci [Administration and Compounding of Euthanasic Agents 1994, Engber 2006]. Są często stosowane również $\mathrm{w}$ weterynarii jako środki do eutanazji małych zwierząt.

\section{Działanie barbituranów}

Barbiturany powodują zstępujące hamowanie ośrodkowego układu nerwowego. Działanie tych związków to aktywne hamowanie tworu siatkowatego w pniu mózgu. Tiopental lub metoheksital wywołują sen po 10-20 s po wstrzyknięciu dożylnym. Przez pierwsze $40 \mathrm{~s}$ głębokość znieczulenia może się zwiększać, jednak z czasem będzie się zmniejszać. Po około 20-30 min świadomość wraca.

\footnotetext{
${ }^{1}$ Uniwersytet Przyrodniczy w Lublinie, Wydział Nauk o Zwierzętach i Biogospodarki, Studenckie Koło Naukowe Nauk o Zwierzętach i Biogospodarki, Sekcja Biochemiczna

22pawel15033@wp.pl
} 
Warto zwrócić uwagę na fakt, iż dawki barbituranów mniejsze niż zalecane do wywołania stanu znieczulenia nie powoduja zniesienia czucia bólu, a może być tak, że zwiększą wrażliwość na bóle somatyczne. Zniesienie wrażliwości na ból somatyczny podczas zabiegów chirurgicznych uzyskuje się przy zastosowaniu dużych dawek barbituranów. Podanie kolejnych dawek tych substancji powoduje kumulację barbituranów w organizmie, a co za tym idzie przedłużenie czasu działania znieczulenia i wybudzania po zabiegu [Larsen 2013].

Barbiturany działają jako dodatnie modulatory allosteryczne, a przy większych dawkach jako agoniści receptorów $\mathrm{GABA}_{\mathrm{A}}$ [Löscher i Rogawski 2012]. GABA są głównymi neuroprzekaźnikami hamującymi w ośrodkowym układzie nerwowym ssaków (OUN). Barbiturany działają farmakologicznie, wydłużając czas otwarcia kanału jonowego $\mathrm{Cl}^{-}$na receptorze $\mathrm{GABA}_{\mathrm{A}}$. Sam kwas barbiturowy nie ma bezpośredniego wpływu na centralny układ nerwowy, natomiast znanych jest ponad 2500 pochodnych związków o właściwościach farmakologicznie czynnych.

Barbiturany o działaniu ultrakrótkim są powszechnie stosowane $\mathrm{w}$ znieczulaniu, ponieważ ich wyjątkowo krótki czas działania pozwala na większą kontrolę. Związki te nie dają charakterystycznych objawów podczas znieczulenia, można jednak zaobserwować: zwężone źrenice, gałki oczne są usytuowane w pozycji środkowej, działanie układu oddechowego czy krążenia jest częściowo upośledzone, a odruchy mrugania oraz ścięgniste są zniesione. Upośledzenie czynności układu krążenia polega na chwilowym spadku ciśnienia tętniczego. Zależy to od prędkości wstrzykiwania leków. Jeśli robi się to wolno to spadek ciśnienia nie jest aż tak zauważalny, ponieważ organizm ma wystarczającą ilość czasu na kompensację tego procesu. Ponadto, przy podaniu barbituranów naczynia żylne się rozszerzają, co powoduje gromadzenie się krwi w żyłach, co z kolei powoduje zmniejszoną ilość krwi w sercu. Następuje wzrost częstości akcji serca, ale objętość wyrzutowa maleje (działanie inotropowe ujemne). Objętość minutowa serca $\mathrm{w}$ umiarkowanych dawkach barbituranów zmniejsza się o maksymalnie $25 \%$, ale już przy dużych dawkach o prawie połowę [Larsen 2013].

Barbiturany, np. tiopental, po podaniu dożylnym upośledzają układ oddechowy w stopniu zależnym od dawki. Reakcja organizmu na zmiany stężenia $\mathrm{CO}_{2}$ oraz hipoksję bywa zniesiona lub osłabiona, objętość oddechowa się zmniejsza, a częstość oddechów wzrasta. Należy zwrócić uwagę na to, że po podaniu dożylnym barbituranów mogą wystąpić kaszel, skurcz krtani lub oskrzeli (zwiększone prawdopodobieństwo przy płytkim znieczuleniu, a przy głębokich nie obserwuje się takich reakcji) [Larsen 2013]. Barbiturany w większości przypadków można stosować jako wolny kwas lub jako sole sodu, wapnia, potasu, magnezu, litu itp. Stosowane są również sole kwasu barbiturowego na bazie kodeiny idioniny. W 1912 r. Bayer wprowadził kolejną pochodną kwasu barbiturowego - fenobarbital - pod nazwą handlową Luminal, jako środek uspokajająco-nasenny. Lek ten działa przede wszystkim uspokajająco. Zatrzymuje on produkcję hormonu tyreotropowego oraz zmniejsza napięcie mięśni gładkich. Wskazaniem do stosowania tego leku są przede wszystkim napady padaczkowe, nadmierna pobudliwość, niekiedy bezsenność. 
Ważną kwestią przy podawaniu środków stosowanych w zabiegu eutanazji jest droga podania. Najszybszą jest podanie dootrzewnowe, zwłaszcza u małych zwierząt, których naczynia krwionośne są małe i trudne do wkłucia. Ta forma aplikacji ma wadę - trochę dłuższy czas rozpoczęcia działania środka w porównaniu z podaniem dożylnym lub dosercowym. Iniekcje domięśniowe, doopłucnowe czy podskórne nie są wykonywane. Wśród iniekcyjnych środków wykorzystywanych w eutanazji na terenie Europy dominują dwa związki: pentobarbital (należy do grupy barbituranów) i embutramid, który podawany jest w preparatach złożonych z lekami uzupełniającymi jego działanie [Taraszkiewicz 2017].

Szybki wlew pentobarbitalu powoduje zgon w ciągu około 2 min [Plumb 2015]. Należy pamiętać, że pentobarbital znosi świadomość pacjenta, ale nie znosi odczuwania bólu, $\mathrm{z}$ tego powodu przed podaniem tego środka stosuje się związki do znieczulania przedoperacyjnego małych zwierząt. Minimalna dawka letalna pentobarbitalu to $100 \mathrm{mg} / \mathrm{kg}$ m.c., czyli kilkukrotnie większa niż dawka znieczulająca. Ważną zaletą stosowania tego środka w porównaniu do innych preparatów iniekcyjnych jest uniwersalność drogi podania, można to zrobić dożylnie, domięśniowo, dootrzewnowo, dosercowo i doopłucnowo. Jednak to podanie dożylne prowadzi do szybkiej utraty przytomności, której towarzyszy minimalny, chwilowy ból związany z nakłuciem. Podanie śródpiersiowe czy dosercowe może być bolesne dla zwierząt z zachowaną świadomością, dlatego te sposoby stosuje się tylko u zwierząt nieprzytomnych. Podanie dootrzewnowe $\mathrm{u}$ dużych zwierząt jest niepraktyczne, ponieważ można łatwo uszkodzić ciało zwierzęcia. Jest to dodatkowo stresujące dla lekarza weterynarii wykonującego zabieg, co wiąże się z dłuższym oczekiwaniem na efekt. Dla porównania, pentobarbital podany dożylnie potrzebuje od 14 do $90 \mathrm{~s}$, by przeniknąć do mózgu, zaś przy podaniu dootrzewnowym - od 5 do 15 min [Riviere i Papich 2009]. Stosowanie tego środka niesie za sobą również działania niepożądane, do których należą: dyszenie, wokalizacja, minimalne skurcze mięśni [Taraszkiewicz 2017].

Stres oksydacyjny można określić jako zaburzenie równowagi między natężeniem procesów oksydacyjnych, które indukują powstawanie reaktywnych form tlenu (RFT) i przeciwdziałającym systemem obronnym - antyoksydacyjnym. [ ulbacka i in. 2009]. Duże znaczenie przypisuje się wolnym rodnikom w peroksydacji lipidów (LPO). Jest to wolnorodnikowy proces utleniania nienasyconych kwasów tłuszczowych lub innych lipidów, w którym powstają nadtlenki tych związków [Sakharov i in. 2005]. W procesie peroksydacji lipidów może wystąpić pewna komplikacja zwana reinicjacją, gdzie nadtlenki lipidów mogą ulegać rozkładowi. Dalsze przemiany produktów LPO zachodzą m.in. drogą $\beta$-eliminacji, co prowadzi do rozpadu reszt wielonienasyconych kwasów thuszczowych i kilkunastowęglowych fragmentów, m.in. dialdehydu malonowego - MDA (ang. malonodialdehyde). Wzrost stężenia MDA w tkankach obserwuje się przy wzroście wytwarzania RFT [Bartosz 2003, Niedernhofer i in. 2003]. 


\section{Badania wlasne}

Celem badań było określenie odpowiedzi na stres oksydacyjny wywołany podczas planowanej eutanazji zwierząt za pomocą pochodnych barbituranu. Dodatkowym założeniem badań była ocena wiedzy i świadomości społeczeństwa na temat stosowania leków o działaniu nasennym i uspokajającym (tj. takich, które zawierają pochodne barbituranów) oraz określenie przekonań użytkowników na temat bezpieczeństwa ich stosowania.

W celu oceny stresu oksydacyjnego u psów poddawanych eutanazji badania przeprowadzono we współpracy z Wydziałem Medycyny Weterynaryjnej Uniwersytetu Przyrodniczego w Lublinie. Materiał badawczy stanowiła krew pobrana od 12 zdrowych psów (grupa kontrolna), od 9 zdrowych psów poddanych eutanazji na wniosek lekarza (powody nieznane) oraz od 9 chorych psów (głównie na choroby nowotworowe). rew od psów poddanych eutanazji pobrano po ok. 10 min od uśpienia zwierząt. We krwi spoktofotometrycznie oznaczono produkt oksydacji lipidów: dialdehyd malonowy (MDA) według metody opisanej przez Salih i in. [1987] oraz testem ELISA pochodne karbonylowe (PC) jako produkt oksydacji aminokwasów.

W badaniach ankietowych materiał badawczy stanowiły opinie 108 osób. Były to 84 kobiety (77\%) oraz 24 mężczyzn (23\%). Wśród ankietowanych znajdowało się 76 osób w wieku $18-30$ lat (71\%) oraz 32 osoby powyżej 30 lat (29\%). Wykształcenie średnie zadeklarowało 65\% respondentów (tab. 1).

Sondaż diagnostyczny przeprowadzono przy pomocy anonimowego kwestionariusza. Ankieta składała się z 24 pytań testowych, wśród których znajdowały się pytania zamknięte jednokrotnego i wielokrotnego wyboru. Były w niej również punkty dotyczące wiedzy na temat substancji uspokajających i nasennych oraz ich znajomości. Dalej respondenci wypowiadali się na temat znajomości mechanizmu działania substancji uspokajających oraz nasennych, a także częstotliwości przyjmowania zawierających je leków.

Badania wykazały, że farmakologiczne usypianie psów (eutanazja) z zastosowaniem pochodnych barbituranów indukuje silny stres oksydacyjny w organizmie. Również stany chorobowe indukują ten proces, o czym świadczą wartości MDA i PC u chorych psów poddawanych eutanazji (tab. 2).

Wśród ankietowanych w pierwszej kolejności sprawdzona została wiedza dotycząca substancji o działaniu nasennym i uspokajającym. Ponad 65\% respondentów nie było w stanie zdefiniować barbituranów. Osoby, które zadeklarowały wiedzę na temat tych substancji, stanowily $35 \%$ wszystkich ankietowanych (rys. 1).

Następne dwa pytania były ze sobą skorelowane, ponieważ jedno z nich odnosiło się do znajomości substancji czynnej leku, którą jest diazepam, zaś drugie dotyczyło znajomości samego leku - Relanium. Substancją czynną preparatu jest diazepam długo działająca pochodna benzodiazepiny (BZD). Ponad połowa respondentów zapytanych o diazepam zadeklarowała, że wie, o czym mowa, co stanowiło $55 \%$, pozostała część ankietowanych (45\%) nie znała takiej substancji. Z kolei aż 85 osób (79\%) za- 
deklarowało znajomość leku Relanium. Zatem przeważająca część ankietowanych zna lek, nie wiedząc nic o jego substancji czynnej (rys. 2).

Tabela 1. Charakterystyka badanej populacji

\begin{tabular}{|c|c|c|c|}
\hline & Kryteria & $\mathrm{N}$ & $\%$ \\
\hline Płeć & $\begin{array}{l}\text { kobiety } \\
\text { mężczyźni }\end{array}$ & $\begin{array}{l}84 \\
24\end{array}$ & $\begin{array}{l}77 \\
23\end{array}$ \\
\hline Wiek & $\begin{array}{l}18-30 \\
31-41 \\
42-50 \\
51-60\end{array}$ & $\begin{array}{c}76 \\
16 \\
11 \\
5\end{array}$ & $\begin{array}{l}71 \\
15 \\
10 \\
4\end{array}$ \\
\hline Wykształcenie & $\begin{array}{l}\text { podstawowe } \\
\text { zawodowe } \\
\text { średnie } \\
\text { policealne } \\
\text { licencjackie } \\
\text { magisterskie } \\
\text { biologiczne, chemiczne, } \\
\text { biochemiczne, pokrewne }\end{array}$ & $\begin{array}{l}0 \\
7 \\
70 \\
9 \\
1 \\
11 \\
10\end{array}$ & $\begin{array}{c}0 \\
6 \\
65 \\
8 \\
1 \\
11\end{array}$ \\
\hline
\end{tabular}

Tabela 2. Wskaźniki stresu oksydacyjnego w krwi psów

\begin{tabular}{|l|c|c|c|}
\hline \multirow{2}{*}{ Wskaźnik } & \multirow{2}{*}{$\begin{array}{c}\text { Psy zdrowe } \\
\text { (niepoddawane } \\
\text { eutanazji) }\end{array}$} & zdrowe & \multicolumn{2}{|c|}{ Psy poddane eutanazji } \\
\cline { 3 - 4 } & (preparat do usypiania - pochodna barbituranów) \\
\hline MDA $\left(\mu \mathrm{mol} \mathrm{l}^{-1}\right)$ & 1,259 & 3,689 & chore \\
PC $(\mathrm{nmm} / \mathrm{mg})$ & 0,635 & 1,582 & 8,644 \\
\hline
\end{tabular}




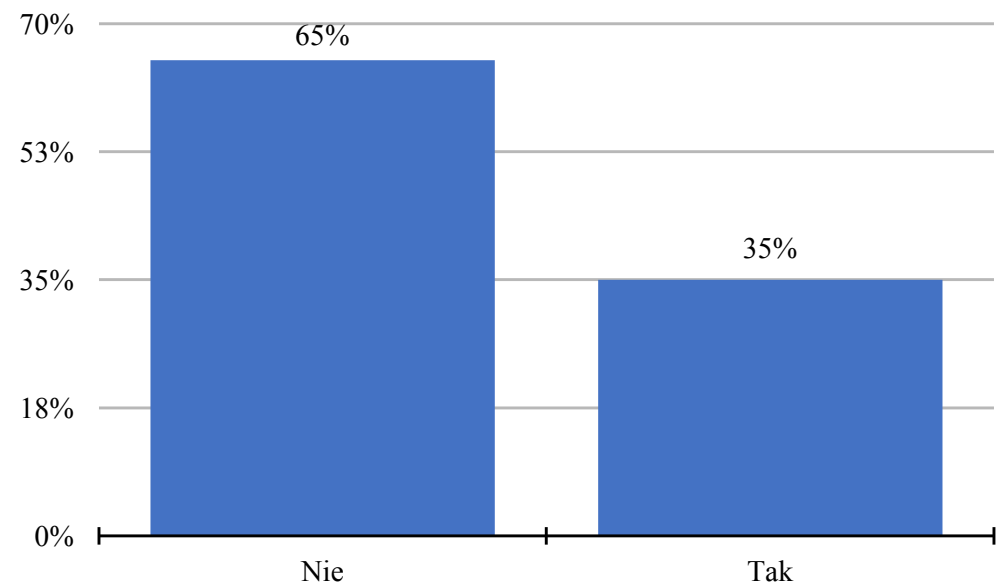

Rys. 1. Wiedza ankietowanych na temat barbituranów

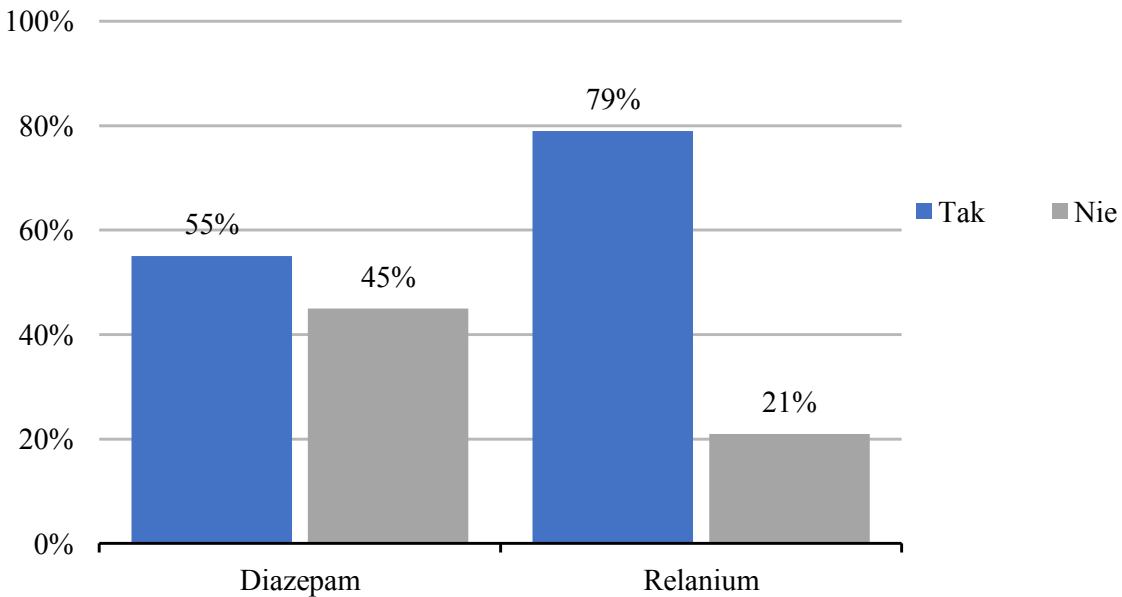

Rys. 2. Znajomość substancji czynnej leku i zawierającego ją leku Relanium

Tylko $18 \%$ ankietowanych zadeklarowało znajomość fenobarbitalu, natomiast znajomość leku Luminal potwierdzono u 49\% respondentów (rys. 3).

Ponad połowa ankietowanych deklarowała znajomość mechanizmu działania leków nasennych (72\%) oraz leków o działaniu uspokajającym (83\%) - rysunek 4. Przeważająca część badanych twierdziła, że nie stosuje leków o działaniu nasennym $(82,2 \%), 16 \% \mathrm{z}$ nich odpowiedziało zaś, że zdarza się im stosować takie substancje kilka razy w miesiącu. Żadna $\mathrm{z}$ pytanych osób nie zadeklarowała stosowania leków nasennych $\mathrm{z}$ częstotliwością raz w tygodniu, natomiast $1,8 \%$ respondentów twierdziło, że przyjmuje je prawie codziennie (rys. 5). 


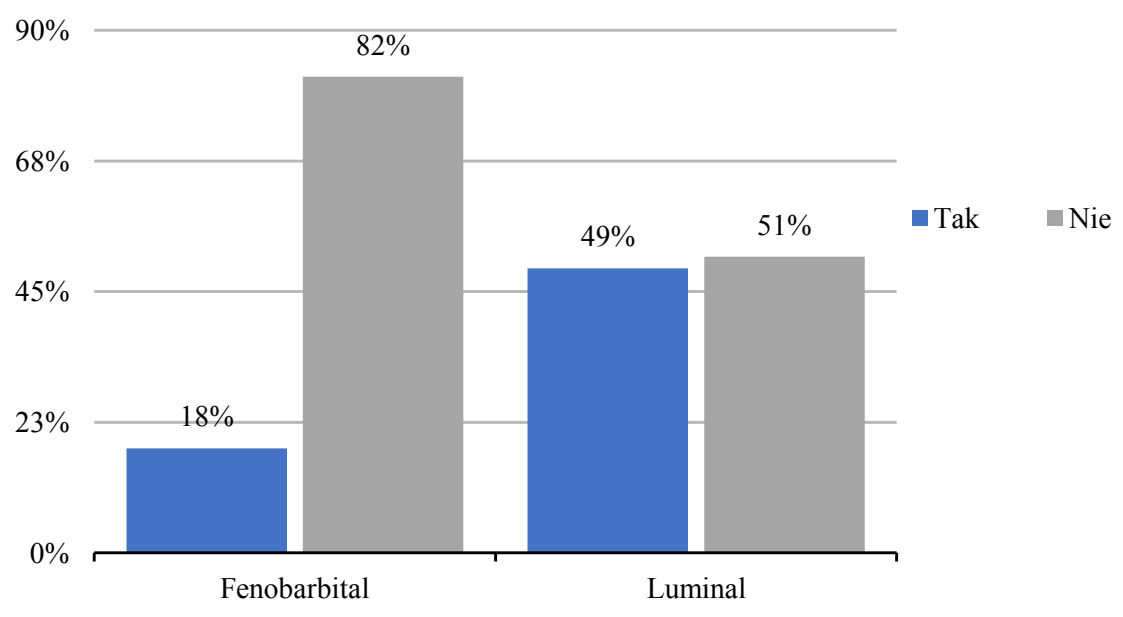

Rys. 3. Znajomość substancji czynnej leku i samego leku Luminal

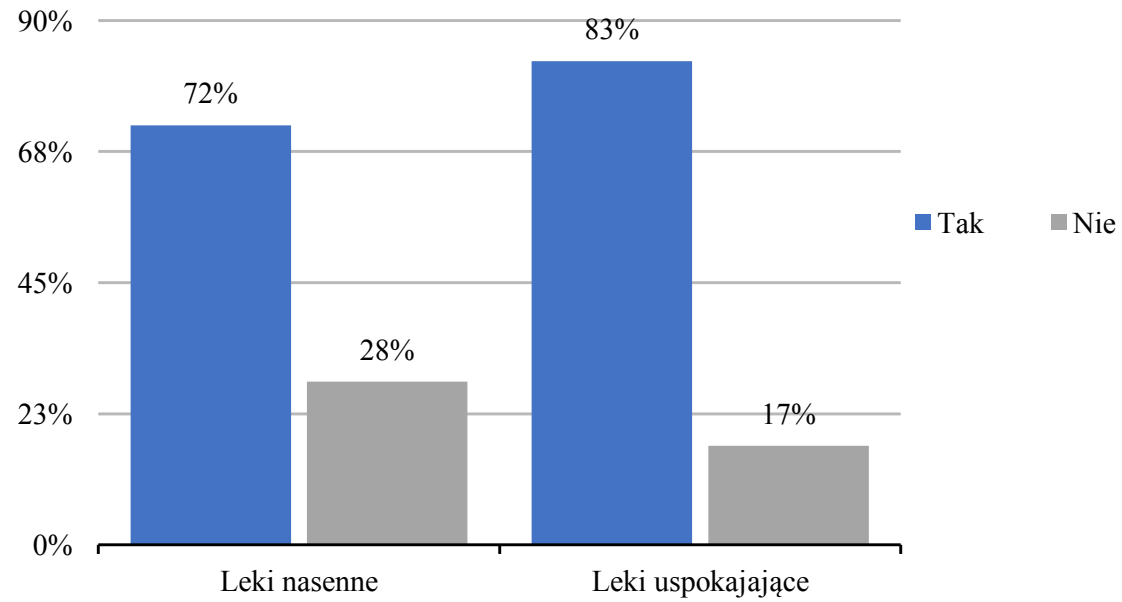

Rys. 4. Znajomość mechanizmu działania leków nasennych oraz uspokajających

Przeważająca część ankietowanych twierdziła, że nie stosuje leków o działaniu uspokajającym $(63,3 \%)$. Z badań wynika także, iż 34\% respondentów zdarzało się zażywać takie substancje kilka razy w miesiącu. Tylko jedna osoba zadeklarowała stosowanie leków nasennych raz w tygodniu, a 1,8\% pytanych przyjmuje je prawie codziennie (rys. 6).

Kolejne pytanie miało na celu sprawdzić, po jakie leki sięgają ankietowani. $20 \%$ respondentów zadeklarowało stosowanie leków OTC (bez recepty), natomiast $8 \%$ przyznało, że czasami zażywają leki na receptę. Także $8 \%$ pytanych 


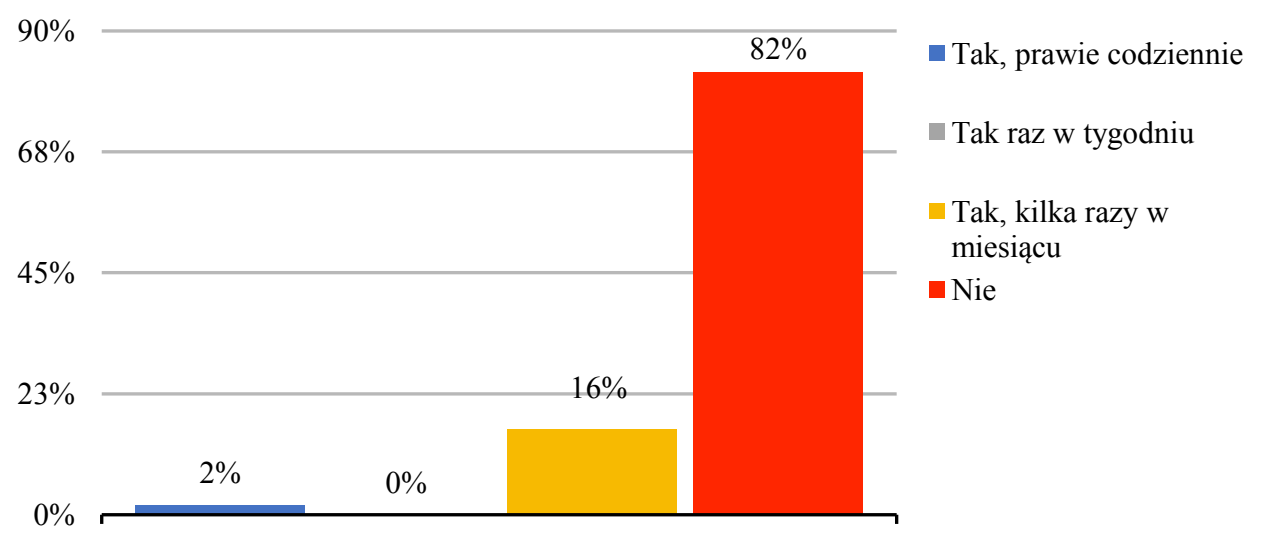

Rys. 5. Częstotliwość zażywania substancji nasennych

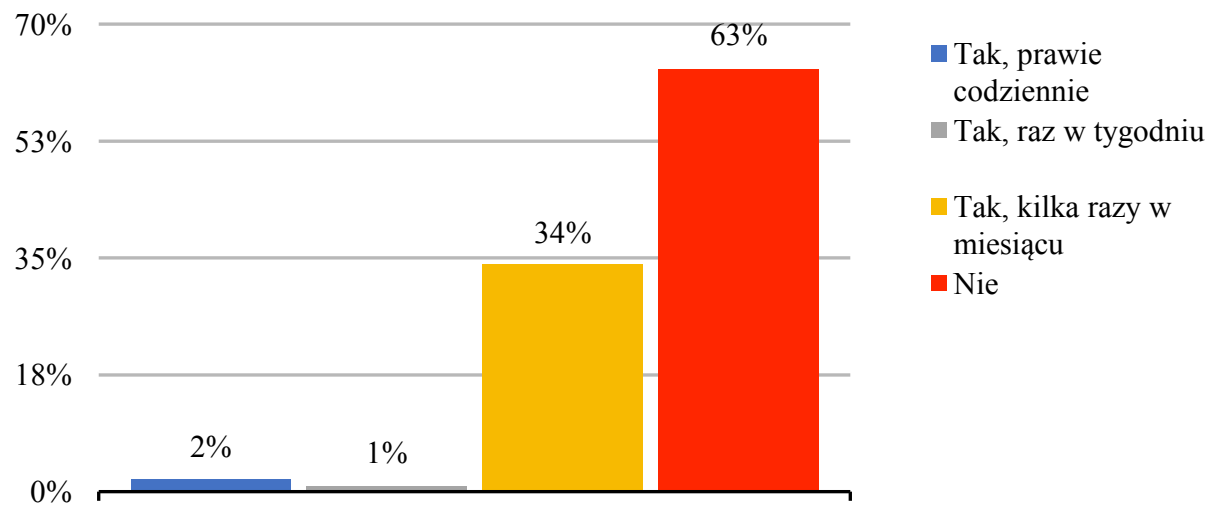

Rys. 6. Częstotliwość zażywania substancji uspokajających

odpowiedziało, że rzadko udają się po receptę. Natomiast aż 7,5\% ankietowanych przyznało się do zażywania tylko tych leków, które są dostępne z przepisu lekarza. Jedna osoba zadeklarowało przyjmowanie jednocześnie leków OTC z lekami przepisanymi przez lekarza w celu osiągnięcia lepszego rezultatu. Aż $53,6 \%$ ankietowanych przyznało, że nie sięgają w ogóle po takie substancje (rys. 7).

Pytanie 14. miało na celu sprawdzić przekonania ankietowanych na temat recept wypisywanych na substancje uspokajające i nasenne. Według części ankietowanych takie substancje są na tyle bezpieczne, że nie wymagają recepty (30,5\%). Natomiast $69,5 \%$ pytanych twierdziło, że recepty są potrzebne i substancje o takim działaniu powinny być przepisywane przez lekarza (rys. 8). 


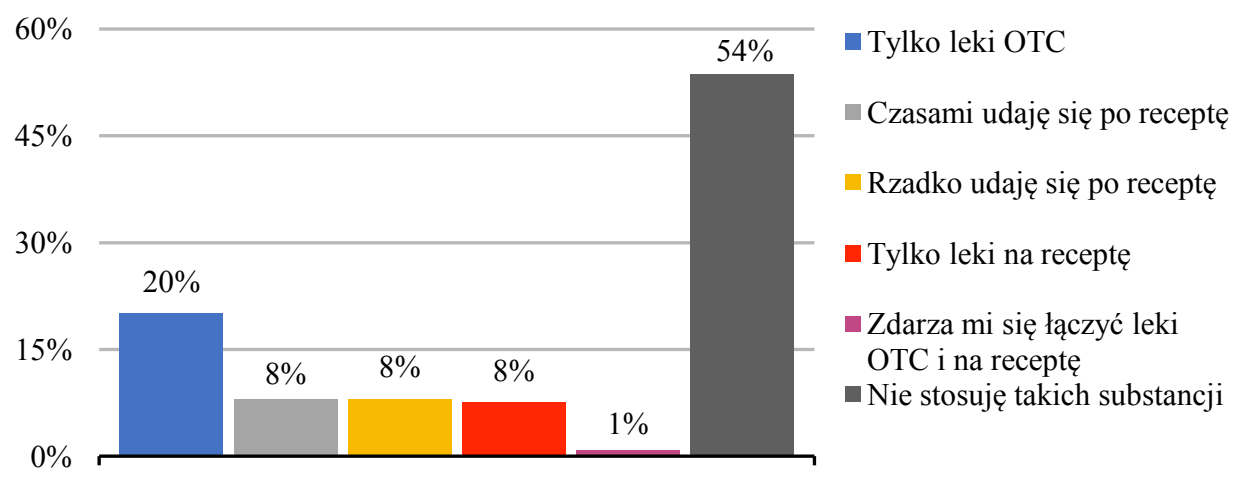

Rys. 7. Stosowanie leków OTC oraz leków z przepisu lekarza przez ankietowanych

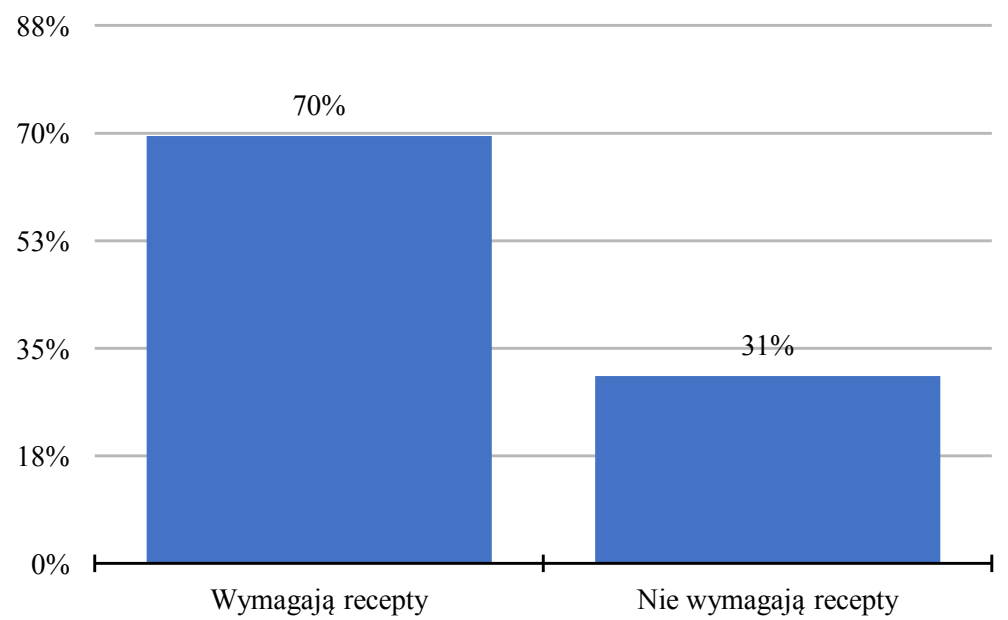

Rys. 8. Przekonanie nt. bezpieczeństwa stosowania (dostępności) leków uspokajających/nasennych

Następne pytanie dotyczyło działań niepożądanych występujących w wyniku stosowania leków uspokajających oraz nasennych. Aż 51\% pytanych zdecydowanie potwierdziło pojawienie się takich działań, a $45 \%$ respondentów bez przekonania przyznało, że raczej mogą się pojawiać. Niepokojące jest, iż w tak medialnych czasach, prawie 5\% pytanych nie wie o działaniach niepożądanych leków lub uważa, że takowe się nie zdarzają (rys. 9).

Kolejne dwa pytania miały na celu sprawdzenie świadomości respondentów w kwestii obecności substancji uspokajających oraz nasennych w innych lekach (rys. 10) oraz stosowanie tychże (substancje należące do barbituranów) w zabiegu eutanazji (rys. 11). Aż $72 \%$ ankietowanych twierdziła, że wiedziała o występowa- 


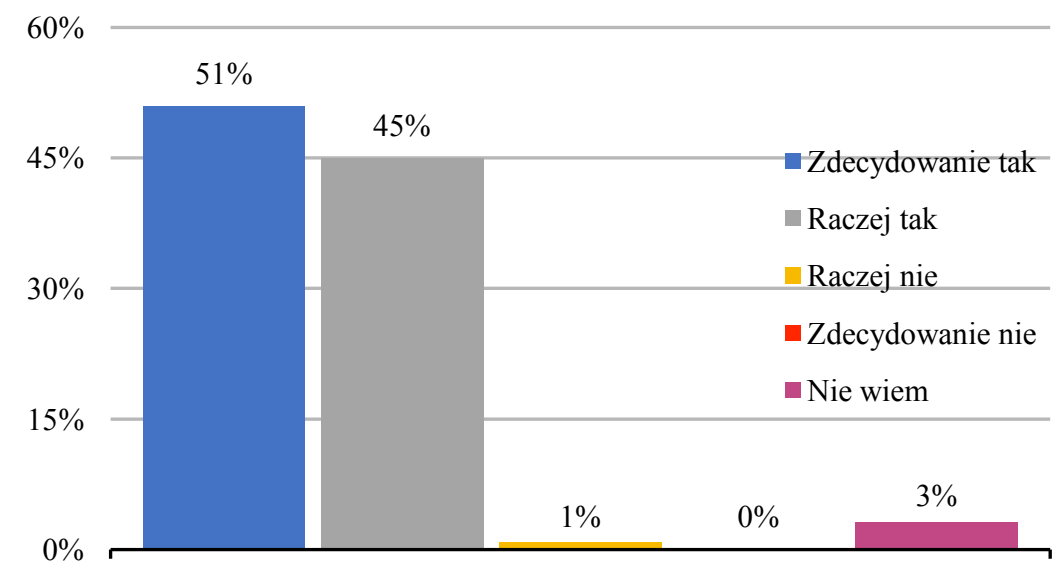

Rys. 9. Odpowiedzi ankietowanych na pytanie o to, czy ich zdaniem stosowanie leków nasennych lub uspokajających może prowadzić do wystąpienia działań niepożądanych

powaniu substancji o działaniu uspokajającym lub nasennym również m.in. w lekach nasercowych, przeciwpadaczkowych, tzw. antydepresantach oraz w lekach na wzmożone napięcie mięśniowe. Aż 28\% badanych osób nie było tego świadomych (rys. 10). Na pytanie dotyczące substancji należących do barbituranów, które są wykorzystywane w zabiegu eutanazji, aż 82\% ankietowanych odpowiedziało negatywnie, natomiast $18 \%$ respondentów wiedziało o używaniu tych substancji do zabiegu (rys. 11).

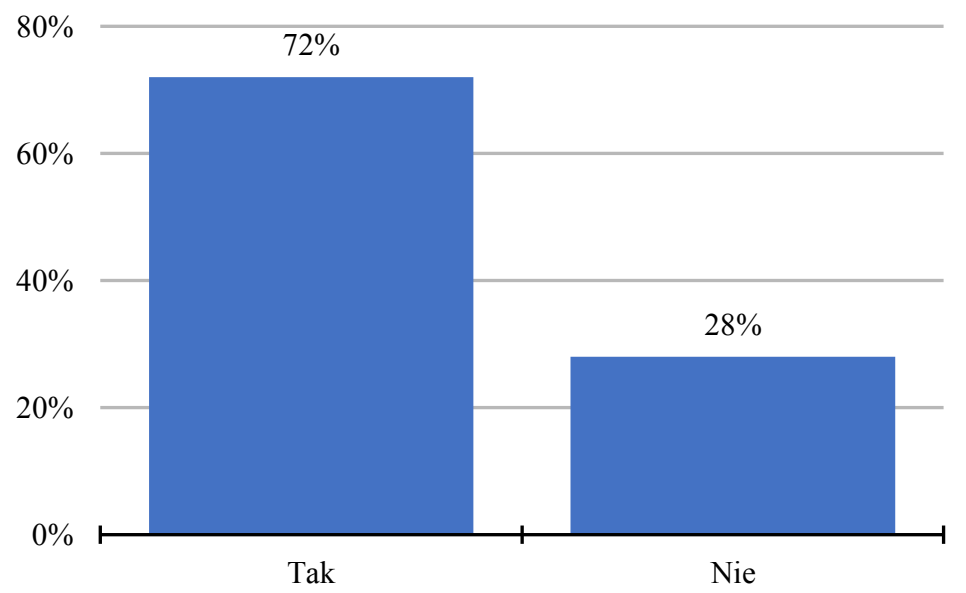

Rys. 10. Pytanie o świadomość tego, że substancje o działaniu uspokajającym oraz nasennym występują w wielu lekach o innym przeznaczeniu 


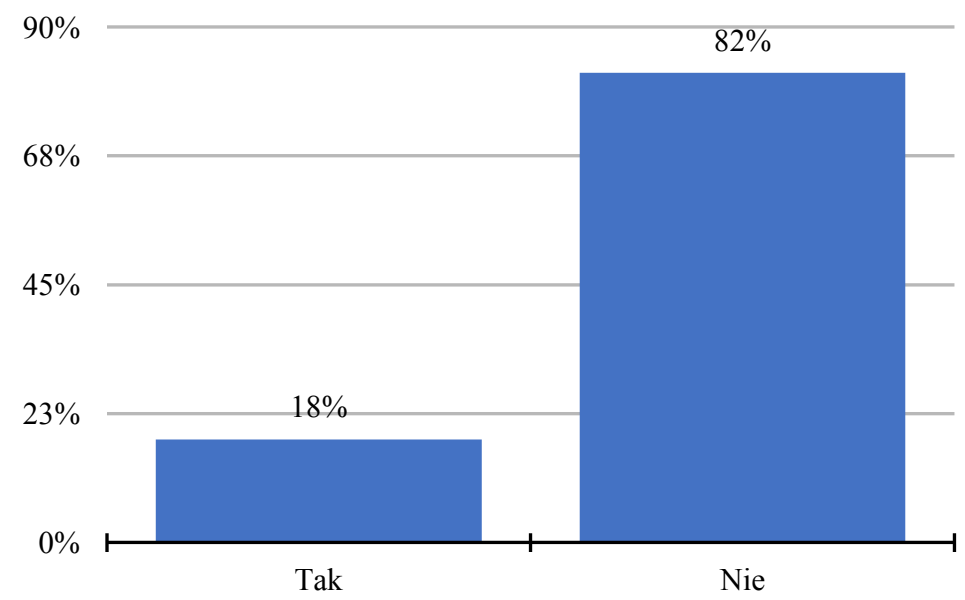

Rys. 11. Pytanie o wiedzę nt. stosowania substancji należących do barbituranów w zabiegu eutanazji

Dalsza część ankiety miała na celu sprawdzenie znajomości działań niepożądanych, skutków przedawkowania oraz świadomości, na co należałoby zwrócić uwagę po zażyciu substancji uspokajających lub nasennych. Tylko 5,5\% ankietowanych zaznaczyło, że po zażyciu tego rodzaju substancji można prowadzić pojazdy mechaniczne. olejne $2,7 \%$ pytanych odpowiedziało, że można po tych lekach spożywać alkohol, 8,5\% stwierdziło, że można łączyć te substancje z innymi lekami bez konsultacji z lekarzem. Jedna osoba zaznaczyła wszystkie te odpowiedzi jako prawidłowe. Aż $83 \%$ ankietowanych stwierdziło, że żadna z podanych odpowiedzi nie jest prawidłowa. Zatem zdecydowana większość pytanych jest świadoma tego, iż po zażyciu substancji uspokajającej/nasennej należy zachować ostrożność, nie prowadzić pojazdów, nie spożywać alkoholu, a w przypadku przyjmowania innych leków konsultować się z lekarzem lub farmaceutą (rys. 12).

Następne pytanie dotyczyło bezpieczeństwa stosowania substancji uspokajających i nasennych przez kobiety ciężarne. Wszyscy respondenci odpowiedzieli, że kobieta $\mathrm{w}$ ciąży nie może stosować takich substancji bez wiedzy lekarza. Pytanie kolejne sprawdzało znajomość konkretnych działań niepożądanych. Możliwe było wybranie kilku odpowiedzi. Mniej niż $40 \%$ ankietowanych zaznaczyło wszystkie trzy objawy, Co oznacza że połowa tylko ta część respondentów była w pełni świadoma skutków ubocznych, jakie mogą wystąpić po zażyciu leków uspokajających lub nasennych. olejne $37 \%$ respondentów uważało, że niepożądanymi objawami, jakie mogą się pojawić, są otępienie oraz problemy z koncentracją. Pozostali ankietowani zaznaczyli tylko jedną z możliwych odpowiedzi. Tylko dwie osoby były zdania, że substancje o działaniu uspokajającym i nasennym nie dają działań niepożądanych (rys. 13). 


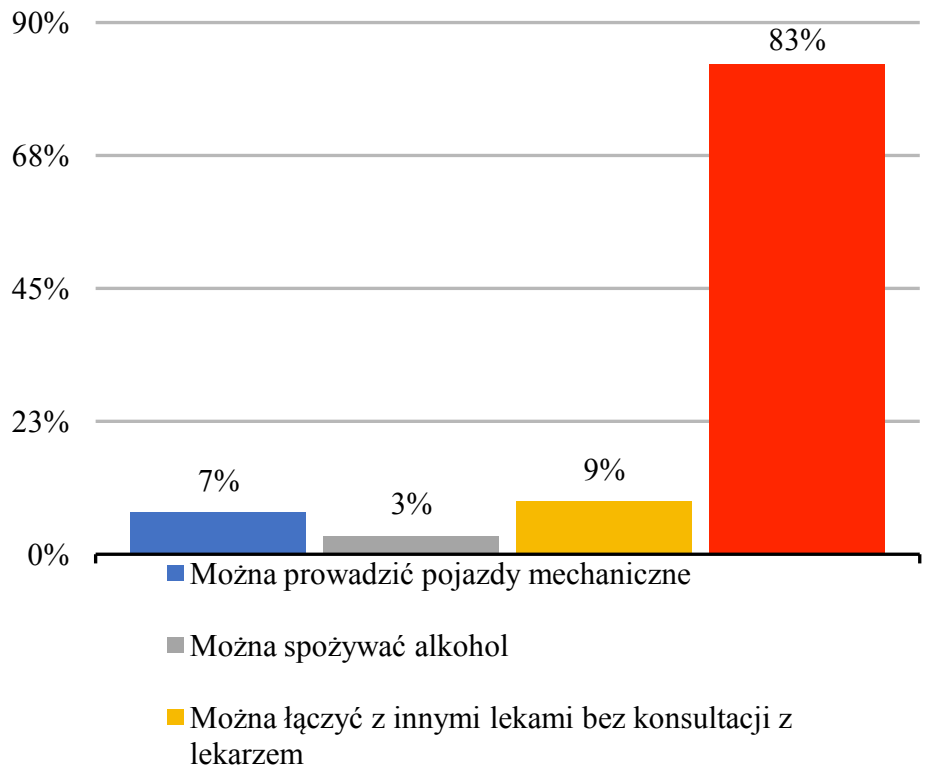

Rys. 12. Odpowiedzi ankietowanych dotyczace wiedzy nt. bezpiecznego stosowania leków uspokajających i nasennych (pytanie w ankiecie: Czy Pana/Pani zdaniem stosowanie leków nasennych lub uspokajających może prowadzić do wystąpienia działań niepożądanych?)

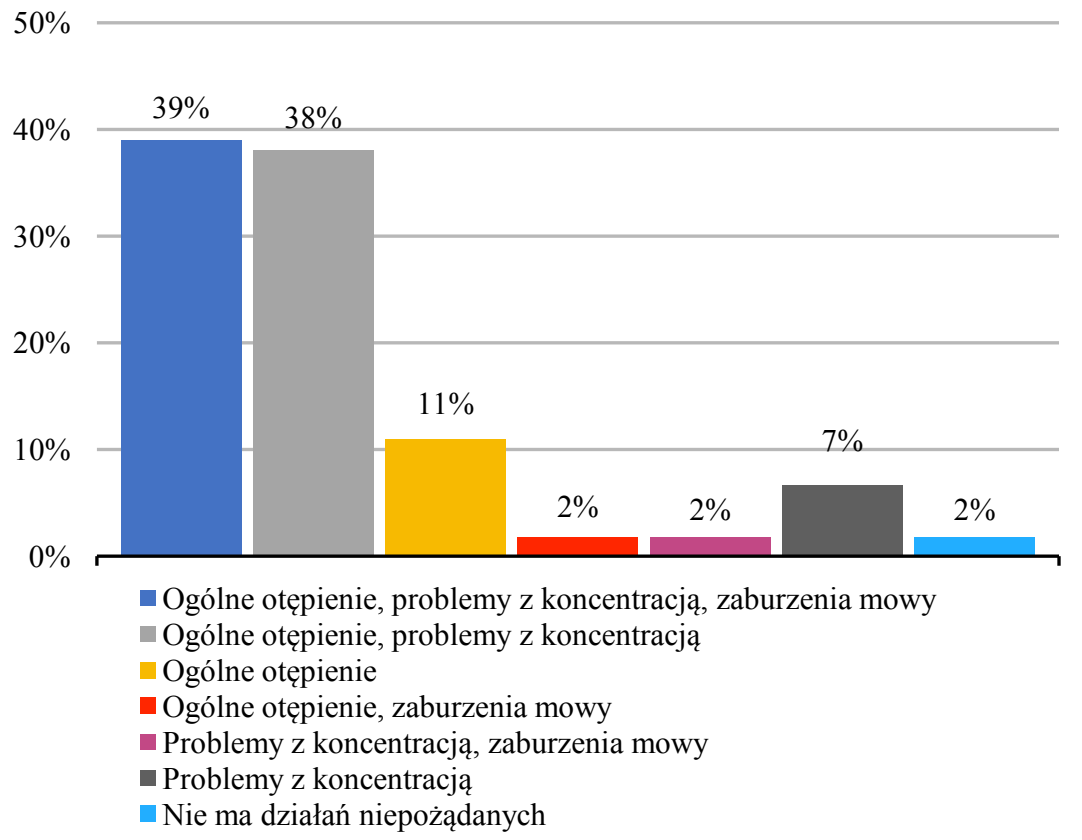

Rys. 13. Przekonania respondentów nt. możliwych działań niepożądanych substancji uspokajających oraz nasennych 
Na pytanie, czy leki o działaniu uspokajającym/nasennym bez wątpliwości można stosować wraz z innymi lekami, 3\% respondentów odpowiedziało, że zdecydowanie tak, $30 \%$ - zdecydowanie nie. Natomiast $67 \%$ osób przyznało, że zawsze konsultuje to z lekarzem (rys. 14).

Na pytanie o interakcje leków aż 93\% ankietowanych odpowiedziało, że wiedzą o możliwych interakcjach między substancjami nasennymi/uspokajającymi a innymi lekami. Tylko 4\% stwierdziło, że nie występują takie interakcje (rys. 15).

Przedostanie pytanie miało na celu sprawdzenie stanu wiedzy społeczeństwa na temat połączenia substancji uspokajającej lub nasennej z alkoholem. Możliwy był wybór kilku odpowiedzi. Tylko 34 osoby na 108 pytanych (31\%) zaznaczyły dwie poprawne odpowiedzi: „wzmożone działania substancji uspokajającej/nasennej” oraz „zatrzymanie akcji serca, zgon”. Pozostałe osoby dobierały odpowiedzi nietypowo (rys. 16).

Ostatnie pytanie sprawdzało, czy ankietowani wiedzą na co w pierwszej kolejności działają substancje uspokajające. $60 \%$ ankietowanych zaznaczyło poprawną odpowiedź - ośrodkowy układ nerwowy, 16\% zaznaczyło serce, 14\% ciśnienie tętnicze. Tylko 12 osób (11\%) zaznaczyło odpowiedź „normują oddech, puls, zanika drżenie rąk".

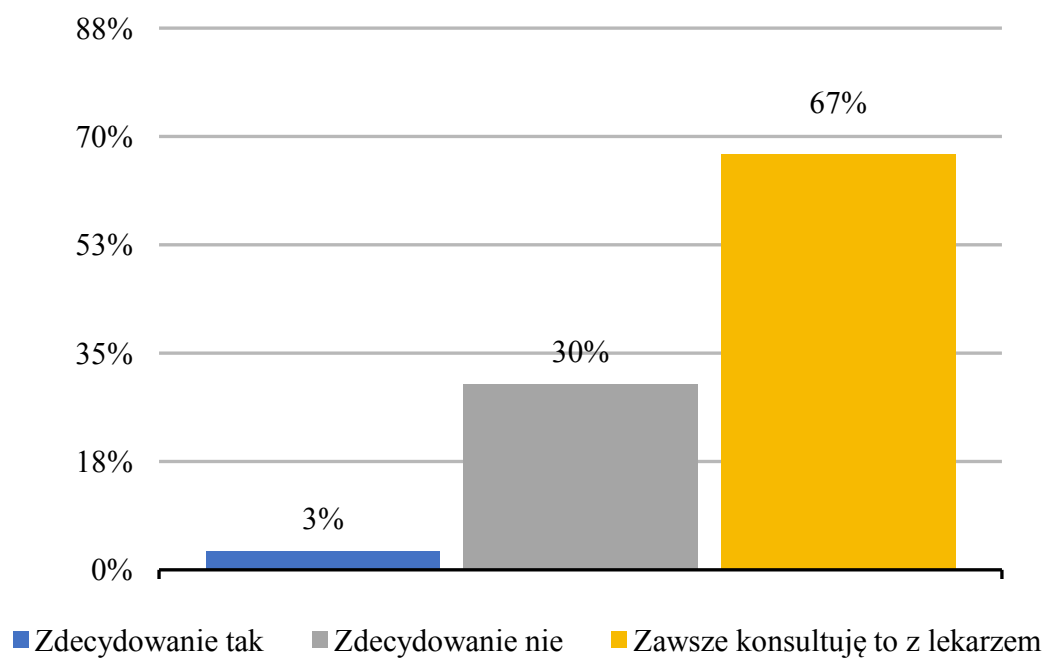

Rys. 14. Przekonania respondentów dotyczące stosowania substancji uspokajających oraz nasennych wraz z innymi lekami

Obecnie duża ilość leków jest dostępna bez wcześniejszej konsultacji z lekarzem i bez recepty. Wszystkie podejrzenia dotyczące ewentualnej szkodliwości substancji uspokajających oraz nasennych na organizm ludzki są uzasadnione, ale niemal zawsze w przypadku niestosowania się do zaleceń zamieszczonych 


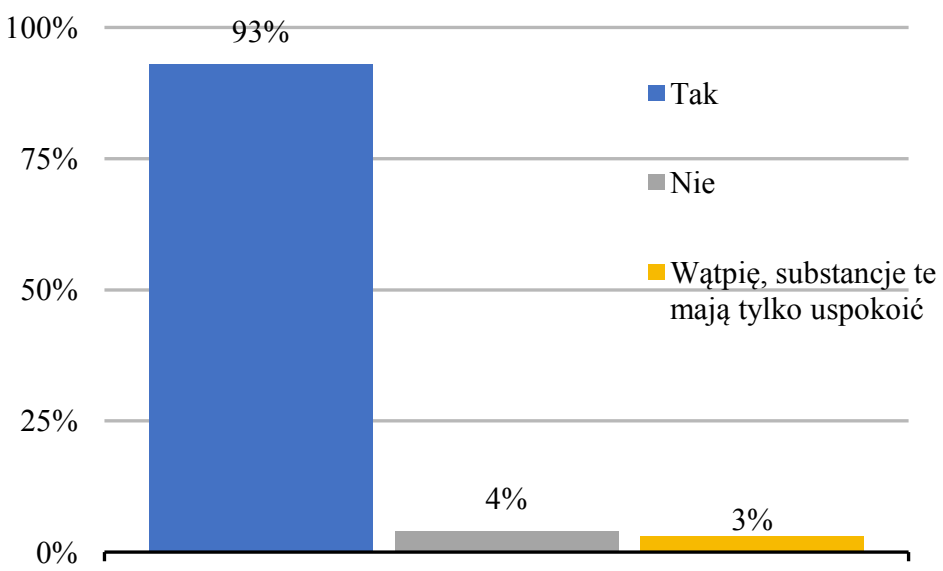

Rys. 15. Przekonania respondentów nt. możliwości występowania interakcji substancji uspokajających i nasennych z innymi lekami

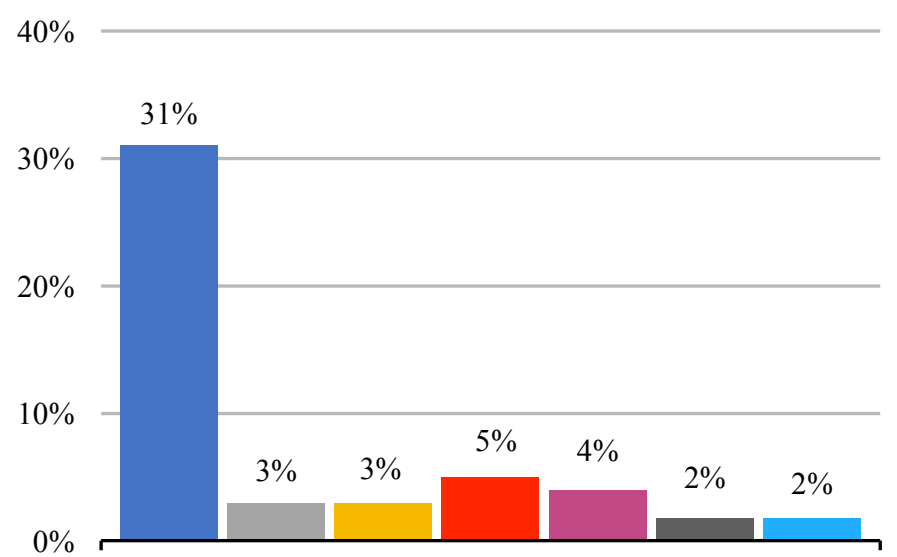

• Wzmożone działanie substancji uspokajającej/nasennej; zatrzymanie akcji serca, zgon

— Wzmożone działanie substancji; może jedynie spotęgować „złe samopoczucie” dnia następnego; zatrzymanie akcji serca, zgon

- Osłabienie działania substancji; wzmożenie działania substancji

- Osłabienie działania substancji; wzmożenie działania substancji; może jedynie spotęgować „złe samopoczucie” dnia następnego; zatrzymanie akcji serca, zgon (wszystkie odpowiedzi) - Osłabienie działania substancji; zatrzymanie akcji serca, zgon

- Osłabienie działania substancji; wzmożenie działania substancji; zatrzymanie akcji serca, zgon

- Może jedynie spotęgować „złe samopoczucie” dnia nastepnego; zatrzymanie akcji serca, zgon

Rys. 16. Przekonania ankietowanych dotyczące łączenia substancji uspokajających i nasennych $\mathrm{z}$ alkoholem 


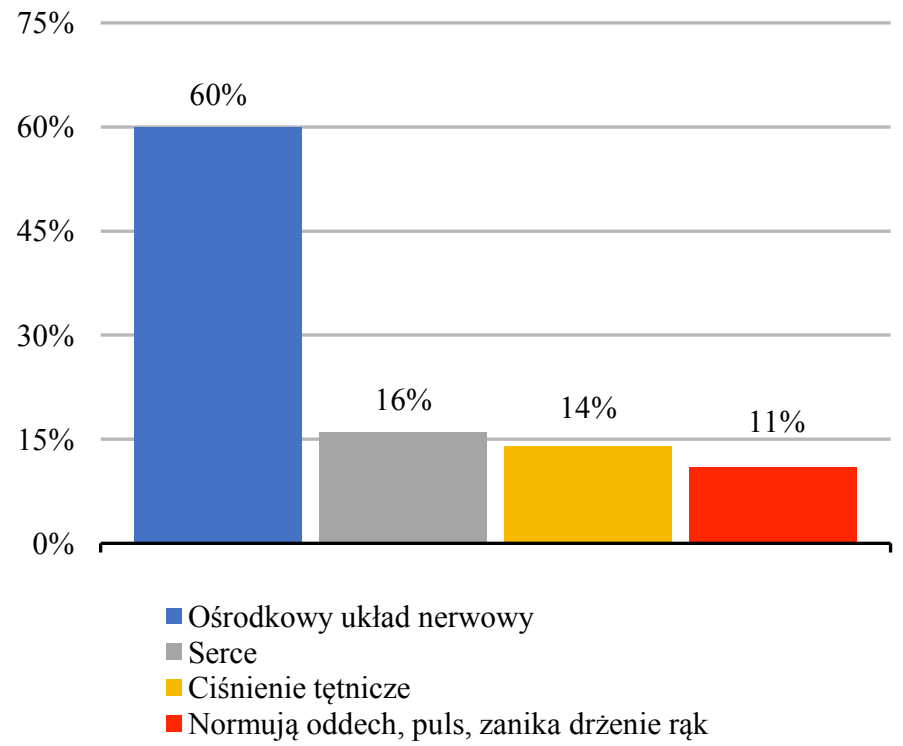

Rys. 17. Przekonań użytkowników nt. tego, na co działają substancje uspokajające

na ulotkach. Stwierdzono, że podczas farmakologicznej eutanazji psów z zastosowaniem związku z grupy barbituranów w organizmie zwierząt następuje wzrost wskaźników świadczących o oksydacji lipidów i białek (stres oksydacyjny). Niepokojące są więc wyniki przeprowadzonej analizy, które ewidentnie wskazują na to, że respondenci byli nieświadomi zagrożenia wynikającego z niewłaściwego stosowania tych substancji. Niepokojąca jest równieżnieświadomość ankietowanych w kwestii skutków zażywania substancji nasennej j jednoczesnego spożywania alkoholu. Tak więc nawet substancje, które w swoim przeznaczeniu mają pozytywnie oddziaływać na zdrowie człowieka stosowane niewłaściwie wywierają na nie szkodliwy lub wręcz toksyczny wpływ.

\section{Bibliografia}

Bartosz G., 2003. Druga twarz tlenu, Wolne rodniki w przyrodzie. PWN, Warszawa. Engber D., 2006. Why do lethal injections have three drugs? Slate Magazine, Nowy Jork.

u lbacka J., Saczko J., Chwiłkowska A., 2009. Stres oksydacyjny w procesach uszkodzenia komórek. Pol. Merk. Lek., Wrocław, 27(157), 44.

Larsen R., 2013. Anestezjologia, t. 1. thum. A. bler. Urban \& Partner, Wrocław.

Leary S., 2013. Guidelines for the Euthanasia of Animals. AVMA, Schaumburg.

Löscher W., Rogawski M., 2012. How theories evolved concerning the mechanism of action of barbiturates. Davis, Epilepsia 53(Suppl. 8), 12-25.

Niedernhofer L.J., Daniels J.S., Rouzer C.A., 2003. Malonodialdehyde, a product of lipid peroxidation, is mutagenic in human cells. Tennessee 278, 31426-31433.

Plumb D.C., 2015. Plumb's Veterinary Drugs Handbook, 8th ed. Hoboken, 413-416.

Riviere J.E., Papich M.G., 2009. Veterinary Pharmacology and Therapeutics, 9th ed. Ames, 401-408. 
Sakharov D.V., Elstak E.D.R., Chenryak B.V., 2005. Prolonged lipid oxidation after photodynamic treatment. Study with oxidation-sensitive probe C11-BODIPY581/591. Cambridge 579, $1255-1260$.

Salih A.M., Smith D.M., Price J.F., Dawson L.E., 1987. Modified extraction 2-thiobarbituric acid method for measuring lipid oxidation in poultry. Poult. Sci. 66(9), 1483-1488.

Taraszkiewicz M., 2017. Eutanazja farmakologiczna - metody iniekcyjne w praktyce weterynaryjnej w Polsce. Życie Wet. 92(3), 181-184. 
Paulina Kamińska ${ }^{1,3}$, Jarosław Kamieniak², Małgorzata Goleman ${ }^{2}$

\section{Wpływ wybranych czynników na wynik zmodyfikowanego egzaminu psa towarzyszącego I stopnia}

The influence of selected factors on the result of the modified Obedience Test I level

\section{Proces uczenia się psa}

Uczenie się można zdefiniować jako proces polegający na trwałej zmianie zachodzącej $\mathrm{w}$ mechanizmach zachowania, nabywanie wybranych informacji lub form zachowania pod wpływem konkretnych bodźców i reakcji, a także doświadczenia bądź powtarzania. W procesie uczenia się podstawowe znaczenie ma warunkowanie. Wyróżniamy warunkowanie klasyczne i instrumentalne zW. inaczej sprawczym [Bargiełowska 2012].

Warunkowanie klasyczne jest procedurą prowadzącą do kojarzenia dwóch wydarzeń, bodźca warunkowego $\mathrm{z}$ bezwarunkowym [Niewiadomska 2005]. Bodziec pierwotnie obojętny dla psa staje się bodźcem warunkowym dzięki temu, że w sposób systematyczny sygnalizuje pojawienie się bodźca o istotnym znaczeniu biologicznym wywołującym wrodzoną reakcję. Tego typu reakcje nazywane są odruchami warunkowymi [Zieliński i Werka 2005]. Za sprawą warunkowania klasycznego zdefiniowane genetycznie odruchy ulegają modyfikacji pod wpływem środowiska oraz doświadczeń danego osobnika. Zmienność odruchów warunkowych potęguje się dzięki związaniu ich z bodźcem bezwarunkowym, co skutkuje efektywniejszym spełnianiem jego przystosowawczej funkcji - sygnalizacji [Zieliński 1993].

Warunkowanie instrumentalne jest najbardziej podstawową formą kształtowania zachowania, pozwala organizmowi uczyć się zależności między własnym zachowaniem a jego konsekwencjami - nagrodą lub karą [O'Doherty i in. 2004]. Często odruchy instrumentalne nazywane są odruchami popędowymi, ze względu na relację między popędem (motywacją) a prezentowaniem różnych czynności motorycznych [Zieliński 1985]. Warunkiem wytworzenia odruchu instru-

\footnotetext{
${ }^{1}$ Uniwersytet Przyrodniczy w Lublinie, Wydział Nauk o Zwierzętach u Biogospodarki, Studenckie Koło Naukowe Nauk o Zwierzętach i Biogospodarki - Sekcja Kynologiczna

${ }^{2}$ Uniwersytet Przyrodniczy w Lublinie, Wydział Nauk o Zwierzętach u Biogospodarki, Katedra Etologii Zwierząt i Łowiectwa

3 paulakaminska403@gmail.com
} 
mentalnego jest powiązanie określonej reakcji ruchowej z pojawiającym się bodźcem bezwarunkowym (np. pokarmem) [Zieliński 1993].

Konsekwencjami zachowania nazywamy wydarzenia, które pojawiają się zaraz po nim i są od niego uzależnione. Rozpoznajemy cztery możliwe procedury zachowań instrumentalnych: wzmocnienie pozytywne, karanie pozytywne, wzmocnienie negatywne i karanie negatywne [O'Heare 2009]. Wzmocnienie pozytywne występuje, gdy zachowanie skutkuje pojawieniem się w środowisku bodźca atrakcyjnego, pożądanego przez zwierzę (np. pokarmu). Kontakt z takim bodźcem jest nagrodą [Zieliński 1993]. Wzmocnienie negatywne, gdzie zachowanie powoduje ustanie działania bodźca awersyjnego bądź zapobiega jego pojawieniu się (np. uniknięcie kary), taki efekt również możemy nazwać nagrodą dla psa. Według Bąbla [2011] wzmocnienia są skutkami prowadzącymi do wzrostu prawdopodobieństwa wystąpienia zachowania w przyszłości, kary zaś prowadzą do zmniejszenia częstotliwości jego występowania. Karą nazywamy zastosowanie bodźców awersyjnych wywołujących reakcje wycofywania się. Kara pozytywna występuje, kiedy zachowanie skutkuje pojawieniem się bodźca awersyjnego oraz kara negatywna, kiedy w rezultacie zachowania ustaje działanie bodźca pożądanego, czyli wzmocnienia, lub bodziec pożądany nie pojawia się wcale [Bąbel 2011].

Badania dotyczące wpływu wybranych czynników na zmodyfikowany egzamin Psa Towarzyszącego I stopnia przeprowadzono na podstawie wyników egzaminu kończącego kurs posłuszeństwa w jednym z lubelskich ośrodków szkolenia psów. Egzamin odbył się z udziałem właścicieli zwierząt, był przeprowadzony przez egzaminatora, który wcześniej prowadził szkolenie. Wszystkie psy były uczone tą samą metodą szkoleniową opartą na wzmocnieniu pozytywnym z użyciem klikera - warunkowanie instrumentalne.

Badaniem objęto 100 psów, w tym 44 suki i 56 samców. Wśród badanych psów 20 były to psy nierasowe, a 80 - psy rasowe. W tej drugiej grupie znalazło się 26 ras, często reprezentowanych zaledwie przez jednego osobnika. Dlatego w celu przeprowadzenia statystycznie wiarygodnego opracowania wyników, w porównaniach dotyczących wpływu rasy na poziom oceny na egzaminie uwzględniono 5 najliczniej reprezentowanych ras (labrador retriever, owczarek niemiecki, golden retriever, berneński pies pasterski, border collie), tzn. przez minimum 5 osobników. Pozostałe psy (32 szt.) to przedstawiciele innych ras (od jednego do trzech osobników z danej rasy). Nie były one brane pod uwagę w zestawieniach określających wpływ rasy na wynik egzaminu. Uznano, że wyniki uzyskane na egzaminie przez jednego a nawet trzech przedstawicieli danej rasy nie są zbyt obiektywne i mogą nie odzwierciedlać faktycznych umiejętności wynikających z przynależności do określonej rasy.

Psy objęte badaniami zakwalifikowano do 4 następujących grup wiekowych: pierwsza - 6-10 miesięcy, druga - 11-14 miesięcy, trzecia - 15-20 miesięcy, cztery - powyżej 20 miesięcy. Najwięcej psów było w wieku od 6 do 10 miesięcy - 63 osobników. W wieku od 11 do 15 miesięcy było 23 osobniki. Najmniej 
liczne grupy stanowiły psy w wieku 16-20 miesięcy i powyżej 20 miesięcy obie po 7 osobników.

Podczas egzaminu pies był prowadzony na smyczy zapiętej na zwykłej obroży bądź szelkach. Nie były dopuszczalne dławiki, kolczatki ani obroże elektryczne. Dodatkowe rekwizyty, które dopuszczano podczas egzaminu, to kocyk, zabawka i małe smaczki dla psa. Do każdego zadania można było podejść tylko raz. Po każdym skończonym zadaniu właściciel nagradzał psa i ponownie skupiał jego uwagę na sobie, przygotowując w ten sposób do kolejnego ćwiczenia. Czas egzaminowania zależał od psa i przewodnika, ponieważ niektóre zwierzęta potrzebowały więcej czasu, aby osiągnąc odpowiedni poziom skupienia. Średnio wynosił on ok. 30 minut. Na egzamin składało się 9 zadań. W 4 z nich punktacja maksymalna wynosiła 15 punktów. Były to ćwiczenia takie jak skupienie uwagi na przewodniku przez 20 sekund, polecenie ,siad” na sygnały osobno optyczny i dźwiękowy, polecenie „waruj” na takich samych zasadach oraz puszczenie zabawki na komendę. Za wykonanie pozostałych zadań pies mógł uzyskać maksymalnie po 20 punktów. Były to zadania takie jak: chodzenie na luźnej smyczy; chodzenie przy nodze w rozproszeniu przez innego przechodzącego psa; polecenie „nie rusz” dotyczące rzucanego na ziemię smakołyku; przywołanie do opiekuna z odległości 10 metrów w sytuacji rozproszenia obecnością innego psa oraz pozostawanie w miejscu przez 60 sekund, mimo przechodzących między psem a przewodnikiem ludzi i zwierząt. Największa ilość punktów, jaką można było zdobyć to 160 , a od uzyskanych 121 egzamin był zaliczany.

Analizowano, czy wiek, płeć i rasa psa wpływa na wynik końcowy egzaminu oraz na ilość zdobytych punktów w poszczególnych zadaniach. W celu określenia różnic $\mathrm{w}$ wynikach egzaminów uzyskanych przez poszczególne grupy badanych psów - dobierane pod względem wieku, płci i rasy. Dla średniej punktacji $\mathrm{w}$ grupach wyliczono średnie arytmetyczne z sum oraz odchylenie standardowe.

\section{Wpływ płci psów na wynik egzaminu}

Samce stanowiły $56 \%$ zwierząt biorących udział w badaniu, natomiast suki $44 \%$. Analizując różnice w zdawalności egzaminu uwarunkowane płcią badanych psów, zauważono, że suki radziły sobie lepiej (72,73\%) niż osobniki męskie $(60,71 \%)$.

Porównując poszczególne ćwiczenia za 15 punktów w grupach płci, stwierdzono, że zwierzęta najlepiej poradziły sobie z zadaniem 4 (polecenie „siad"): psy uzyskały $14,02 \pm 2,60$ pkt, suki $-14,55 \pm 1,45$ pkt. W ujęciu łącznym dla obu płci było to średnio $14,25 \pm 2,18$ pkt. Najniższa średnia punktacja u obu płci została przyznana za zadanie 1 (koncentracja na przewodniku). U psów było to $11,52 \pm 4,15 \mathrm{pkt}$, u suk $-11,02 \pm 4,77 \mathrm{pkt}$, łącznie (średnio razem psy i suki) $11,30 \pm 4,42$ pkt. W zadaniach za 20 punktów najwyższy średni wynik stwierdzono w przypadku zadania 6 (polecenie ,nie rusz”), odpowiednio: dla psów - 
$18,04 \pm 4,92$ pkt, dla suk $-18,75 \pm 4,05$ pkt, łącznie $-18,35 \pm 4,55$ pkt. Najniższy średni wynik odnotowano przy zadaniu 3 (chodzenie przy nodze). Dla psów wyniósł on $10,61 \pm 4,15$ pkt, dla suk $-12,18 \pm 6,18$ pkt, a łącznie $-11,30 \pm 4,42$ pkt. Suki miały wyższy średni wynik końcowy egzaminu - 133,20 $\pm 19,26$ pkt - niż psy - 123,86 $\pm 19,92$ pkt. Średnia końcowa punktacja (wynik egzaminu) w ujęciu łącznym (dla obu płci) wyniosła 127,97 $\pm 20,08$ pkt.

Na podstawie badań własnych, stwierdzono, że suki były bardziej podatne na szkolenie i uzyskały wyższe wyniki od samców. Wyniki te są zgodne z badaniami Elliot i Scott [1965], w których udowodniono, że suki były bardziej posłuszne. Również Fiszdon [2004] zauważyła istotne różnice między płcią psów a tendencjami do niektórych zachowań, które wpływają na poziom posłuszeństwa. Podobne wyniki uzyskał Karpiński i in. [2009], który stwierdził, że suki uzyskały istotnie wyższe wyniki od psów. W badaniach Goleman [2010] nie odnotowano statystycznie istotnych różnic pomiędzy wynikami psów obu płci, jednak suki otrzymywały więcej ocen bardzo dobrych. Jedynie w badaniach Svartberg [2002] nie dowiedziono wpływu płci psów na wyniki testu, w których zwierzęta wzięły udział.

\section{Wpływ rasy psów na wynik egzaminu}

Porównując punktację przyznaną psom reprezentującym poszczególne rasy za ćwiczenia, za które mogły otrzymać maksymalnie 15 punktów, stwierdzono, że najlepiej poradziły sobie one z zadaniem 4 (polecenie ,siad”) - psy nierasowe uzyskały średnio $14,7 \pm 1,12$ pkt, psy rasy labrador retriever $-13,53 \pm 3,86$ pkt, owczarki niemieckie $-14,00 \pm 2,11$ pkt, berneńskie psy pasterskie $-14,17 \pm 2,04$ pkt. Psy rasy border collie najwyższe wyniki osiągnęły w dwóch zadaniach - w zadaniu 4 oraz w zadaniu 9 (polecenie ,puść”) - w obydwu po $15 \pm 0,00$ pkt. Psy rasy golden retriever najwyższy wynik uzyskały w zadaniu 5 (polecenie „waruj”), gdzie ich punktacja przyjęła wartość $13,89 \pm 2,20$ pkt oraz, podobnie jak border collie, w zadaniu $9-13,89 \pm 3,33$ pkt. Wszystkie psy nierasowe i reprezentujące 5 najliczniej reprezentowanych podczas tego egzaminu ras najgorzej poradziły sobie z zadaniem 1 (koncentracja na przewodniku), uzyskując następującą średnią punktację: psy nierasowe $-10,25 \pm 4,13$ pkt, psy rasy labrador retriever $-10,88 \pm 5,37$ pkt, owczarki niemieckie $-10,50 \pm 4,97$ pkt, psy rasy golden retriever $-11,67 \pm 3,54 \mathrm{pkt}$, berneńskie psy pasterskie $-11,57 \pm 4,08 \mathrm{pkt}$, psy rasy border collie $-10,83 \pm 5,85$ pkt. W przypadku ćwiczeń za 20 punktów, w zadaniu 6 (polecenie „nie rusz”) najwyższą średnią punktację osiągnęły psy nierasowe $-19,25 \pm 1,83$ pkt, owczarki niemieckie $-19,00 \pm 3,16$ pkt, berneńskie psy pasterskie - 19,17 $\pm 2,04$ pkt. Dla golden retrieverów najłatwiejsze okazało się zadanie 7 (przywołanie do opiekuna) - 18,44 $\pm 2,13$ pkt. Psy rasy border collie uzyskały najwyższą średnią punktację za zadania 6 i 7, w których uzyskały po $19,17 \pm 2,04$ pkt. Najtrudniejsze okazało się zadanie 3 (chodzenie przy no- 
dze), za które psy poszczególnych ras uzyskały następujące średnie wartości punktacji: psy nierasowe $-13,00 \pm 6,68 \mathrm{pkt}$, labrador retrievery $-9,18 \pm 4,49 \mathrm{pkt}$, owczarki niemiecki $-11,50 \pm 5,95$ pkt, golden retrievery $-12,33 \pm 7,23$ pkt, berneńskie psy pasterskie $-10,67 \pm 4,18$ pkt oraz border collie $-14,67 \pm 5,16$ pkt. Najwyższy średni końcowy wynik egzaminu $(140,67 \pm 15,92$ pkt) uzyskały psy rasy border collie. Psy rasy berneński pies pasterski uplasowały się na drugim miejscu $131,00 \pm 17,89$ pkt. Średnia punktacja dla golden retrieverów i psów nierasowych była zbliżona, odpowiednio wynosiła $130,56 \pm 22,50$ pkt i $130,20 \pm 18,36$ pkt. Owczarki niemieckie uzyskały na egzaminie średnio $129,10 \pm 19,63$ pkt. Najniższy wynik miały psy rasy labrador retriever - średnio $119,65 \pm 19,80 \mathrm{pkt}$.

Psy nierasowe stanowiły $20 \%$ ogółu badanych psów, $80 \%$ - psy rasowe, wśród których wyodrębniono 5 najliczniej reprezentowanych ras. Największą pod względem liczebności grupę stanowily psy rasy labrador retriever $(17 \%$ wszystkich zwierząt biorących udział w badaniu), na drugim miejscu uplasowały się owczarki niemieckie (10\%). Kolejną grupę tworzyły golden retrievery $(9 \%)$, a najmniej liczną berneńskie psy pasterskie i border collie (po 6\%).

Największą $(83,33 \%)$ zdawalność wśród zwierząt biorących udział w badaniu odnotowano dla przedstawicieli rasy border collie. Zdawalność owczarków niemieckich wyniosła 70\%, berneńskich psów pasterskich oraz golden retrieverów po $66,67 \%$. Psy nierasowe wykazały zdawalność na poziomie $60 \%$, a najniższą zdawalnością charakteryzowały się labrador retrievery $-52,94 \%$.

Wyniki uzyskane na egzaminie dają możliwość uszeregowania ras psów pod względem efektywności uczenia się. Nie można tych wyników uogólniać w stwierdzeniu o wyższości danej rasy nad inną. Zestawienie 5 najwyższych i najniższych wyników egzaminu pokazuje, że psy w obrębie tej samej rasy osiągały zarówno najlepsze, jak i najgorsze wyniki egzaminu.

Na podstawie badań własnych stwierdzono istotny wpływ rasy na wynik egzaminu. Najwyższe wyniki uzyskały psy rasy border collie, a najniższe - labrador retriever. Takie same dane pojawiły się w badaniach Karpińskiego i in. [2009], którzy dodatkowo stwierdzili, że psy pasterskie mają najwyższe wyniki testów, a najniższe - psy obronne. Goleman [2010] w swoich badaniach stwierdziła, że psy z pasją do aportowania i przynoszenia różnych przedmiotów (psy pasterskie i aportery) dużo łatwiej poddawały się szkoleniu i lepiej zdawały egzaminy $\mathrm{w}$ porównaniu $\mathrm{z}$ psami bez takiego instynktu. W badaniach Fiszdon [2004] również zauważono, że najbardziej podatne na szkolenie są psy pasterskie i aportery - ze względu na ich przeznaczenie do pracy z człowiekiem i potrzebą bycia blisko związanym z przewodnikiem. Wykazano też, że psy rasy labrador retriever, golden retriever, berneński pies pasterski oraz border collie charakteryzują się dużą zdolnością uczenia się i zapamiętywania. Natomiast wyniki w badaniach Pongrácz i in. [2005] pokazały, że istnieją tylko niewielkie różnice między rasami $\mathrm{w}$ obrębie danej grupy ras i żadna $\mathrm{z}$ nich nie uzyskuje lepszych wyników niż pozostałe. W badaniach Svartberg [2002] oraz Kania- 
-Gierdziewicz i in. [2013] stwierdzono, że niektóre psy lepiej niż inne wykonują przydzielone im zadania, jednak nie ma na to wpływu przynależność do rasy.

Publikacje, podręczniki i popularna literaturana temat psów łączą poszczególne rasy z wyraźnymi cechami behawioralnymi i umiejętnościami umysłowymi, jednak istnieje bardzo niewiele badań porównawczych dotyczących różnic rasowych. Może być to spowodowane efektem zróżnicowanej selekcji w procesie tworzenia ras, ponieważ zostały one opracowane na potrzeby wykonywania bardzo specyficznych zadań (np. podążanie tropem krwi - psy gończe, wypasanie owiec owczarki, wyszukiwanie drapieżników w podziemnych norach - jamniki). Przeznaczenie konkretnych ras psów bardzo utrudnia porównywanie ich na podstawie wyników ściśle określonych zadań egzaminu.

\section{Wpływ wieku psów na wynik egzaminu}

Najwięcej psów było w wieku 6-10 miesięcy, stanowily one 63\% wszystkich zwierząt objętych badaniami. Kolejną pod względem liczebności grupę tworzyły psy w wieku $11-15$ miesięcy $-23 \%$. Najmniej liczne były psy w wieku 16-20 miesięcy i powyżej 20 miesięcy -po 7\%.

Najwyższą zdawalność egzaminu (71,46\%) uzyskały psy w wieku 16-20 miesięcy. Zdawalność psów w wieku 6-10 miesięcy i 11-15 była zbliżona, kształtowała się na poziomie odpowiednio $64,06 \%$ i $60,87 \%$. Najniższy wynik uzyskały psy powyżej 20 miesięca życia - 16,67\%.

Porównując poszczególne ćwiczenia za 15 punktów, stwierdzono, że psy we wszystkich grupach wiekowych najlepiej poradziły sobie z zadaniem 4 (polecenie ,siad”), uzyskując średnio: w grupie pierwszej - 14,38 $\pm 1,67$ pkt, drugiej $13,91 \pm 3,36$ pkt, trzeciej $-14,29 \pm 1,89$ pkt, czwartej - 14,17 $\pm 2,04$ pkt. W pierwszej (6-10 miesięcy) oraz trzeciej (15-20 miesięcy) grupie wiekowej najniższą średnią punktów psy uzyskały za zadanie 1 (koncentracja na przewodniku), zdobywając odpowiednio po $11,02 \pm 4,42$ pkt i $11,43 \pm 5,56$ pkt. W grupie drugiej (11-14 miesięcy) najniższą średnią punktację psy uzyskały za zadanie 5 (polecenie „waruj”) - 11,52 $\pm 4,63$ pkt. Natomiast w grupie czwartej (powyżej 20 miesięcy) najniższą średnią wartość punktacji odnotowano za zadania 1 i 5, odpowiednio po $10,83 \pm 4,92$ pkt i $10,83 \pm 5,85$ pkt. W ćwiczeniach za 20 punktów, w grupie pierwszej (6-10 miesięcy) najwyższą średnią punktację oznaczono w zadaniu 7 (przywołanie do opiekuna) $-17,78 \pm 3,94$ pkt. W drugiej i trzeciej grupie wiekowej najwyższą średnią psy uzyskały za zadanie 6 (polecenie „,nie rusz”), zdobywając odpowiednio po 19,78 $\pm 1,04$ pkt i $20 \pm 0,00$ pkt. Czwarta grupa wiekowa najlepiej poradziła sobie w zadaniach 6 i 7 , średnia punktacja za nie wyniosła po $17,50 \pm 4,18$ pkt. Psy w wieku 16-20 miesięcy uzyskały najwyższą średnią punktację w wyniku końcowym egzaminu $-134,29 \pm 17,16$ pkt. Średnia wyniku dla psów w wieku 11-15 miesięcy przyjęła wartość 129,22 $\pm 18,43$ pkt, nato- 
miast dla zwierząt w wieku 6-10 miesięcy 127,69 $\pm 20,97$ pkt. Najniższą średnią uzyskały psy powyżej 20 miesięcy $-118,83 \pm 20,83$ pkt.

Pongrácz i in. [2005] stwierdzili, że wiek psów poddanych badaniom, nie wpływa na ich zdolność uczenia się. W badaniach Karpińskiego i in. [2009] również nie stwierdzono istotnego wpływu wieku na wyniki przeprowadzanych testów. Jednak według Kubinyi i in. [2009] wiek zwierząt miał wpływ na zdolności szkoleniowe psów biorących udział w badaniu. Badania Kanii-Gierdziewicz i in. [2013] wykazały, że najlepszy wiek na poddanie psa szkoleniu to średnio 16 miesiąc życia, co jest zgodne z wynikami badań przeprowadzonych przez autorów.

Na efektywność nauki może wpływać wiele czynników takich jak metoda szkoleniowa, czas poświęcony na powtarzanie ćwiczeń, relacja z przewodnikiem, stan zdrowia, doświadczenie, usposobienie, wiek, płeć czy rasa psa. Zbadanie wpływu wybranych czynników na wynik egzaminu posłuszeństwa może pomóc $\mathrm{w}$ wyborze odpowiedniej rasy i płci psa w zależności od jego przeznaczenia oraz wieku, w którym powinien rozpocząć szkolenie, aby nauka była jak najbardziej efektywna.

Podsumowując, stwierdzono, że płeć ma wpływ na wynik zmodyfikowanego egzaminu psa towarzyszącego I stopnia. W przeprowadzonych badaniach wykazano, iż rasa wpływa na wynik tegoż egzaminu. Dowiedziono również, że znaczenie ma również wiek zwierzęcia.

\section{Bibliografia}

Bargiełowska K., 2012. Kiedy i jak uczyć psa? VETperso 4, 38.

Bąbel P., 2011. Terapia behawioralna zaburzeń rozwoju z perspektywy analizy zachowania. Psych. Rozw. 16(3), 27-38.

Elliot O., Scott J.P., 1965. The analysis of breed differences in maze performance in dogs. Anim. Behav. 13(1), 5-18.

Fiszdon K., 2004. Znaczenie predyspozycji behawioralnych w wyborze rasy psa do towarzystwa. Życ. Wet. 79(3), 148-151.

Goleman M., 2010, Impact of sex, age and raising place on puppies' aptitude tests results, Rocz. Nauk. Pol. Tow. Zootech. 6(1), 37-44.

Kania-Gierdziewicz J., Pałka S., Kozioł K., Gierdziewicz M., 2013. Długość użytkowania i przyczyny wycofania ze służby psów policyjnych. Rocz. Nauk. Pol. Tow. Zootech. 9(4), 6571.

Karpiński M., Czyżowski P., Drozd L., Goleman M., 2009. Wpływ czynników środowiskowych i rasy na inteligencję adaptacyjną psów. Med. Wet. 65(3), 201-204.

Kubinyi E.,Turcsan B., Miklosi A., 2009. Dog and owner demographic characteristics and dog personality trait associations. Behav. Proc. 81, 392-401.

Niewiadomska G., 2005. W poszukiwaniu molekularnych mechanizmów pamięci. W: Mózg a zachowanie, Górska T., Grabowska A., Zagrodzka J. (red.), PWN, Warszawa, s. 340.

O’Doherty J., Dayan P., Schultz J., Deichmann R., Friston K., Dolan R.J., 2004. Dissociable Roles of Ventral and Dorsal Striatum in Instrumental Conditioning. Science 304, 452-454.

O’Heare J., 2009. Zachowania agresywne u psów. Król A. (tłum.). Galaktyka, Łódź, 224-226.

Pongrácz P., Miklósi Á., Vida V., Csányi V., 2005. The pet dogs ability for learning from a human demonstrator in a detour task is independent from the breed and age. Appl. Anim. Behav. Sci. 90(3-4), 309-323. 
Svartberg K., 2002. Shyness-boldness predicts performance in working dogs. Appl. Anim. Behav. Sci. 79, 157-174.

Zieliński K., 1985. Jerzy Konorski's theory of conditioned reflexes. Acta Neurobiol. Exp. 45, 173-186.

Zieliński K., 1993. Warunkowanie a powstanie asocjacji. Kosmos 42(2), 427-452.

Zieliński K., Werka T., 2005. Procesy warunkowania. W: Mózg a zachowanie, Górska T., Grabowska A., Zagrodzka J. (red.). PWN, Warszawa, 376-377. 


\title{
Zachowania stereotypowe wilków szarych utrzymywanych w warunkach Ogrodu Zoologicznego we Wroclawiu
}

\author{
Stereotypic behaviors in gray wolves living in the ZOO Wrocław
}

Utrzymywanie zwierząt $\mathrm{w}$ ogrodach zoologicznych ma długą tradycję, ale cel tych działań znacząco się zmienił. Dawniej zwierzęta w nich przebywające stanowiły wyłącznie eksponaty i miały być źródłem rozrywki dla zwiedzających. Współczesne ogrody zoologiczne to instytucje, które, oprócz niewątpliwego waloru rekreacyjnego, posiadają wiele różnych funkcji związanych z działaniami na rzecz ochrony bioróżnorodności, edukacji oraz optymalizacji warunków utrzymania zwierząt w kontekście ich potrzeb gatunkowych [Habel i Wójcik 2011, Mirecka 2013].

Wilki na przestrzeni dziejów były często postrzegane przez człowieka jako potencjalne zagrożenie, co nie pozostawało bez wpływu na wielkość populacji tego gatunku. Polowanie na wilki dla trofeów czy nawet tępienie ich przyczyniły się do drastycznego spadku liczebności tych zwierząt. W Polsce obecnie wilk traktowany jest jako gatunek zagrożony i na podstawie Rozporządzenia Ministra Środowiska z dnia 16 grudnia 2016 r. w sprawie ochrony gatunkowej zwierząt objęty ochroną czynną.

Warunki, w jakich są utrzymywane wilki, podobnie jak inne gatunki zwierząt, we współczesnych ogrodach zoologicznych są sukcesywnie optymalizowane w kontekście podnoszenia poziomu dobrostanu [Mirecka 2013]. Dotyczy to głównie wprowadzania rozwiązań, które, poprzez nawiązanie do elementów środowiska naturalnego, dają możliwość zaspokajania potrzeb wynikających z przynależności gatunkowej [Paquet i Darimont 2010, Bernacka i in. 2014].

Warunki niezbędne do zapewnienia zwierzętom dobrostanu polegają na zapewnieniu odpowiedniego pożywienia, miejsca schronienia i odpoczynku, ochrony przed chorobami i stresem (a w razie potrzeby leczenia) oraz możliwości wyrażania normalnego behawioru [Kowalski 2005]. Wydaje się

\footnotetext{
1 Uniwersytet Przyrodniczy w Lublinie, Wydział Nauk o Zwierzętach i Biogospodarki, Studenckie Koło Naukowe Nauk o Zwierzętach i Biogospodarki - Sekcja Behawiorystyki Zwierzat

2 Uniwersytet Przyrodniczy w Lublinie, Wydział Nauk o Zwierzętach i Biogospodarki, Katedra Etologii Zwierząt i Łowiectwa

${ }^{3}$ wanda.krupa@up.lublin.pl
} 
jednak, że wysoki poziom dobrostanu to nie tylko zaspokojenie podstawowych potrzeb biologicznych, ale także odpowiednia jakość życia zależna znacząco od statusu emocjonalnego zwierzęcia [Fraser i in. 1997]. Dlatego też zapewnienie wysokiego poziomu dobrostanu jest szczególnie trudne w przypadku zwierząt dzikich utrzymywanych w ograniczeniu wolności [Paquet i Darimont 2010].

Zwierzęta urodzone i żyjące $\mathrm{w}$ ograniczeniu wolności nigdy nie będą zachowywać się identycznie jak osobniki funkcjonujące $\mathrm{w}$ środowisku naturalnym. Jednak poprzez zapewnienie im warunków umożliwiających pełną ekspresję wrodzonych form zachowania można znacząco podnieść ich poziom dobrostanu i przybliżyć ich budżet dobowy do charakterystycznego dla osobników żyjących na wolności oraz zmniejszyć prawdopodobieństwo występowania anomalii behawioralnych [Frezard i Le Pape 2003, Bashaw i in. 2007, Cummings i in. 2007].

\section{Stereotypie jako forma zaburzenia zachowania}

Zachowania nazywane stereotypiami można zdefiniować jako powtarzające się formy reaktywności behawioralnej, przebiegające według określonego schematu i niemające wyraźnego celu. Stereotypie występują w różnych formach u wielu gatunków zwierząt i są zwykle odpowiedzią na znaczące różnice pomiędzy rzeczywistymi warunkami utrzymania a preferowanymi przez zwierzę i/lub zaspokajającymi jego potrzeby gatunkowe [Mason 1991, Sergiel i in. 2012a, 2012b]. Zachowania stereotypowe mogą być manifestowane zarówno w różnych formach aktywności, jak i bardziej dyskretnie - poprzez długotrwałe utrzymywanie nietypowej pozycji ciała [Mason 1991, Bashaw i in. 2001, 2007].

Przyczyną występowania zachowań stereotypowych może być stała obecność różnych czynników lub ich okresowe natężenie. Dla niektórych gatunków może to być stres wywoływany nowym nieznanym obiektem, głośnym dźwiękiem czy obecnością innych osobników lub człowieka. Jedna z koncepcji wyjaśniających pojawianie się i utrwalanie stereotypii wskazuje na znaczenie nadmiernego pobudzenia układu nerwowego lub braku odpowiedniej stymulacji ze strony środowiska, co zwykle skutkuje frustracją. W pewnym uproszczeniu więc zachowania stereotypowe mogą być próbą poradzenia sobie przez zwierzę z niekomfortową dla niego sytuacją [Kowalski 2005, Sergiel i in. 2012a, 2012b].

Stereotypie różnią się pod względem formy i stałości ruchów, częstotliwości występowania oraz rodzaju wywołującego je bodźca. Okazuje się ponadto, że bodźce wywołujące takie zachowania też nie są stałe, ale mogą być zależne od cech indywidualnych, gatunku czy towarzyszącej im sytuacji. Wydaje się jednak, iż występowanie zachowań stereotypowych jest ewidentnym skutkiem zaburzeń w prawidłowej interakcji na płaszczyźnie środowisko-zwierzę [Passini i Kaleta 
1999, Bashaw i in. 2001, Garner i in. 2003, Kaleta 2003, Kowalski 2005, Bashaw $i$ in. 2007, Sergiel in. 2012a, 2012b]. Ponadto osobniki utrzymywane w tych samych warunkach środowiskowych mogą wykazywać różne formy zachowań, co z kolei wskazuje na predyspozycje genetyczne oraz indywidualne cechy osobnicze [Bereszynski i in. 1999, Kowalski 2005].

Negatywny wpływ zachowań stereotypowych na prawidłowe funkcjonowanie zwierząt w ich naturalnym środowisku życia motywuje do poszukiwania sposobów ich eliminacji czy chociaż ograniczania [Sergiel i in. 2012b, Kania 2017]. W niektórych przypadkach możliwa jest terapia za pomocą leczenia farmakologicznego, a stosowane substancje są indywidualnie dobierane z uwzględnieniem statusu emocjonalnego zwierzęcia oraz środowiskowego kontekstu prezentowanego zachowania [Garner i in. 2003, Kania 2017]. Farmakoterapia w przypadku zaburzeń tego typu wydaje się jednak być rozwiązaniem krótkoterminowym, stosowanym jako uzupełnienie modyfikacji zachowania. Celowe jest natomiast podejmowanie profilaktyki występowania stereotypii, polegającej na dodawaniu bodźców, które nie wywołują niekorzystnego pobudzenia układu nerwowego, stanów awersyjnych czy nadmiernego stresu. Oczywiście należy pamiętać, by wykorzystywane bodźce znajdowały się w obszarze zainteresowania zwierzęcia, podwyższały jego poziom motywacji czy wywoływały zachowania eksploracyjne [Shepherdson i in. 1993, Złamal i Kaleta 1997, Bashaw i in. 2001, Frezard i Le Pape 2003].

W przypadku kiedy zwierzę jest zmotywowane do konkretnego działania, ale nie ma możliwości podjęcia go, odczuwa frustrację, której efektem może być zastąpienie prawidłowych zachowań stereotypowymi. Uaktywnienie układu neuroendokrynnego $\mathrm{w}$ takich sytuacjach skutkuje utrwaleniem zaburzonego zachowania, a często zwiększeniem jego udziału w budżecie dobowym [Singer 2009]. Powszechna jest opinia, że stereotypie szybciej rozwijają się w warunkach ubogiego w bodźce środowiska, ale często przyczyną ich rozwoju może być niemożliwość uniknięcia nieprzyjemnego bodźca $\mathrm{z}$ powodu chociażby ograniczonego terytorium [Bereszyński i Skrzypczak 2003].

Zachowania stereotypowe u zwierząt $\mathrm{w}$ ogrodach zoologicznych często nabierają sztywności oraz charakteru mechanicznego, jeżeli są ignorowane przez obsługę przez dłuższy czas [Sergiel i in. 2012b]. Jedną z najczęstszych form zachowań stereotypowych prezentowanych przez zwierzęta utrzymywane na ograniczonej przestrzeni są stereotypie lokomotoryczne. Aktywność tego rodzaju może obejmować całe ciało (chodzenie tam i z powrotem, bieganie jedną drogą oraz chodzenie w koło) lub jego część (poruszanie głową czy wyginanie szyi). Stałe wykonywanie tych samych ruchów może mieć negatywny wpływ na zdrowie, ale przede wszystkim świadczy o niekorzystnym statusie emocjonalnym zwierzęcia i może być traktowane jako wskaźnik obniżonego poziomu dobrostanu [Kaleta 2003]. 


\section{Wpływ utrzymywania w ograniczeniu wolności na zachowanie wilków}

W badaniach własnych oceniano zachowanie wilków szarych utrzymywanych w warunkach Ogrodu Zoologicznego we Wrocławiu. Celem obserwacji była próba oszacowania częstotliwości występowania u nich zachowań stereotypowych oraz analiza budżetu innych form aktywności. Obserwację stada składającego się z czterech osobników (dwa osobniki dorosłe, dwa osobniki młode; jeden samiec i trzy samice) prowadzono metodą próbek czasowych [Altmann 1974]. Wszystkie formy behawioru prezentowanego przez oceniane osobniki rejestrowano podczas pięciominutowych sesji, w godzinach 7.00-19.00 w okresie od 26 kwietnia do 5 maja 2019 r. Rejestrowano również występowanie, czas trwania oraz formę zachowań stereotypowych wyodrębnionych na podstawie badań pilotażowych (tab. 1).

Stado wilków w Ogrodzie Zoologicznym we Wrocławiu utrzymywane jest w południowej części obiektu w sekcji „Zwierzęta Europy” na obszarze 3452,55 m². Zwierzęta mają do dyspozycji wybieg wewnętrzny i zewnętrzny (mogą swobodnie się przemieszczać). Charakter wybiegu odzwierciedla środowisko naturalne wilków. Na środku znajduje się grota, w której wilki mogą ukrywać się przed deszczem czy zbyt silnym słońcem. Wybieg przypomina fragment lasu $\mathrm{z}$ odwzorowującą go szatą roślinną $\mathrm{i}$ dobudowanym zbiornikiem wodnym o powierzchni $116,89 \mathrm{~m}^{2}$, z którego wilki mogą swobodnie pić. Zwiedzający mają do dyspozycji trzy punkty obserwacyjne na różnych poziomach: wiatę na poziomie gruntu, ziemiankę $\mathrm{z}$ grotą pośrodku wybiegu i ambonę widokową o wysokości $3 \mathrm{~m}$. Mimo że warunki środowiskowe zaaranżowane dla stada wilków są zbliżone do naturalnych trudno traktować je jako optymalne. $\mathrm{Na}$ wolności wilki żyją w grupach rodzinnych zajmujących terytoria o znacznej powierzchni (nawet kilkaset kilometrów kwadratowych), a pokarm zdobywają, polując [Zimen 1981, 1982, Okarma 1992, Mech i Boitani 2003, Bernacka i in. 2014, Kuźniewicz i Gulda 2014]. Ograniczona powierzchnia, brak typowych aktywności (zdobywanie pokarmu) oraz skład socjalny stada może skutkować frustracją, a w efekcie zmianą behawioru [Cummings $i$ in. 2007].

Procentowy udział obserwowanych form zachowania stada wilków zestawiono na rysunku 1. Prezentowana aktywność jest dość typowa dla osobników tego gatunku utrzymywanych $\mathrm{w}$ ograniczeniu wolności [Bereszyński i Skrzypczak 2002].

Tabela 1. Etogram zachowań stereotypowych wilka opracowany na podstawie własnych obserwacji

\begin{tabular}{|l|l|}
\hline \multicolumn{1}{|c|}{ Zachowanie stereotypowe } & \multicolumn{1}{c|}{ Opis obserwacji } \\
\hline Chodzenie tam i z powrotem & $\begin{array}{l}\text { regularne przemieszczanie się tam i z powrotem wzdłuż } \\
\text { punktu widokowego, utrzymywanie stałego tempa poru- } \\
\text { szania się oraz ułożenia sylwetki (fot. 1) }\end{array}$ \\
\hline Bieganie jedną trasą & $\begin{array}{l}\text { regularne bieganie po stałej trasie, utrzymywanie stałego } \\
\text { tempa poruszania się oraz ułożenia sylwetki }\end{array}$ \\
\hline
\end{tabular}


Podczas pierwszych dni obserwacji aktywność wszystkich osobników była bardzo niska. Być może było to spowodowane wysoką temperaturą, zwłaszcza w godzinach południowych. Samiec Maks większość czasu spędzał w grocie na środku wybiegu, samice leżały w zacienionych miejscach.

Podczas trzeciego dnia obserwacji aktywność całego stada znacząco wzrosła, a u dwóch osobników (samiec Maks i samica Auris) zaobserwowano zachowania stereotypowe (tab. 1, fot. 1). Jak ustalono na podstawie wywiadu retrospektywnego, samiec Maks od przybycia do wrocławskiego ogrodu zoologicznego wykazywał zachowania stereotypowe w stałej formie. Chodził wzdłuż punktu obserwacyjnego dla zwiedzających tam i z powrotem, w stałym tempie i z utrzymaniem charakterystycznego ułożenia sylwetki (fot. 1). W poprzednim ogrodzie zoologicznym (w Opolu) Maks ponad rok przebywał w odizolowanych od pary wilków „,boksach zapleczowych”. Miał do dyspozycji boksy zewnętrzne, ale w każdym był tylko jeden rodzaj podłoża (słoma, kora, kostka brukowa). Wydaje się, że taki, niewystarczający z punktu widzenia potrzeb gatunkowych, sposób utrzymania spowodował poszukiwanie formy radzenia sobie z frustracją. Jak podaje wielu autorów, rozwój stereotypii jest częstym zjawiskiem w przypadku utrzymywania zwierząt w ubogim środowisku [Mason 1991, Kowalski 2005, Cummings i in. 2007, Sergiel i in. 2012b].

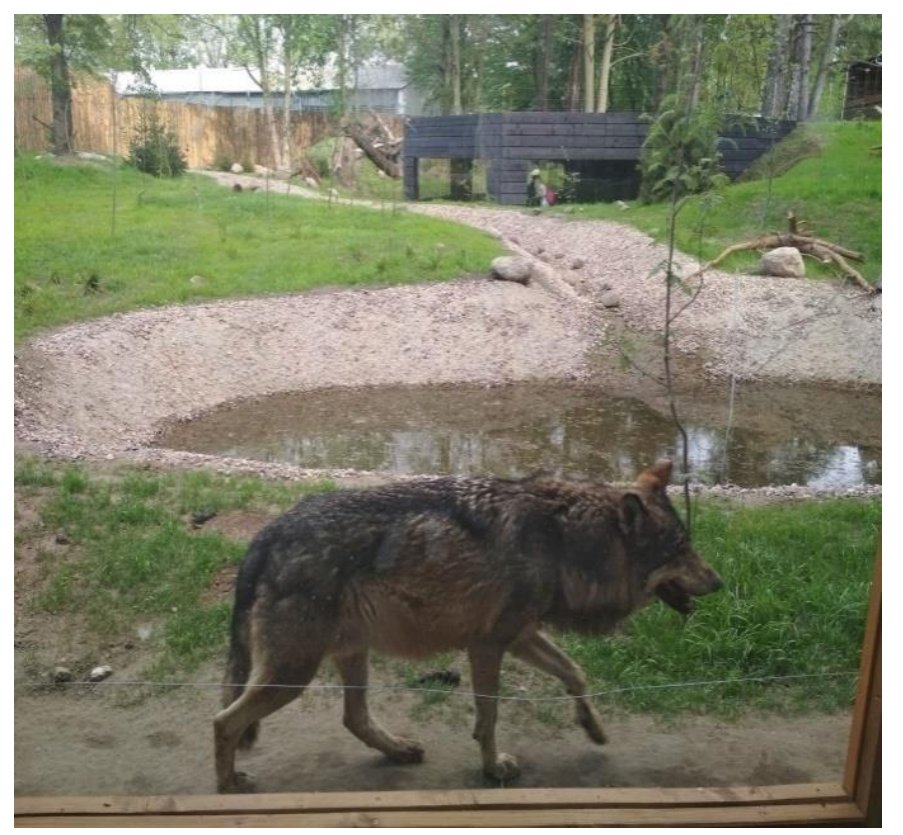

Fot. 1. Samiec Maks wykazujący zachowania stereotypowe - chodzenie wzdłuż punktu widokowego tam i z powrotem (fot. A. Korenitska) 
Przy ograniczaniu występowania stereotypii wielu autorów zwraca uwagę na znaczenie jakości środowiska i wskazuje na potrzebę wzbogacania go w adekwatny gatunkowo sposób [Shepherdson i in. 1993, Frezard i Le Pape 2003, Cummings i in. 2007].

Wydaje się jednak, że przy utrwalonych zachowaniach stereotypowych zastosowanie wzbogaceń nie jest wystarczające [Kania 2017]. U ocenianego samca zwiększenie powierzchni wybiegu oraz zoptymalizowanie bodźców środowiskowych nie wyeliminowało problematycznego zachowania.

Drugim osobnikiem $\mathrm{z}$ ocenianego stada, u którego zidentyfikowano zachowania o charakterze stereotypii, była jedna $\mathrm{z}$ młodych samic (Auris). Jednak okazywane były one jedynie sporadycznie, a czas ich trwania był, w porównaniu do innych form zachowania, stosunkowo krótki. Samica ta wykazywała się również dość wysoką aktywnością w kontekście eksplorowania i oznaczania wybiegu. Zachowania stereotypowe w formie regularnego biegania stałą trasą występowały najczęściej po dłuższym odpoczynku. Mogły być efektem niedostatecznego (w kontekście potrzeb młodego osobnika) środowiska. Należy więc zwrócić uwagę, że w zarządzaniu środowiskiem, w aspekcie profilaktyki zaburzeń zachowania powinno się uwzględniać również potrzeby osobnicze, a nie tylko gatunkowe.

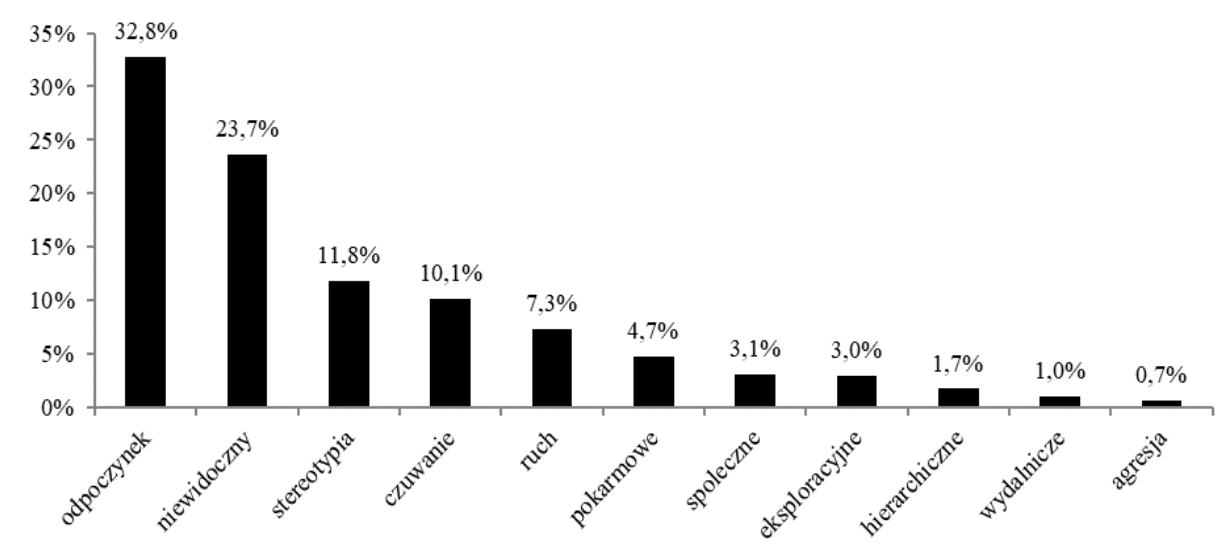

Rys. 1. Procentowy udział poszczególnych zachowań podczas obserwacji wszystkich osobników

Zachowania stereotypowe występujące u dwóch osobników ze stada wilków szarych utrzymywanych w warunkach Ogrodu Zoologicznego we Wrocławiu wskazują na potrzebę zweryfikowania rutynowych sposobów wzbogacania środowiska zwierząt żyjących w ograniczeniu wolności. Może to znacząco poprawić komfort funkcjonowania poszczególnych osobników. 


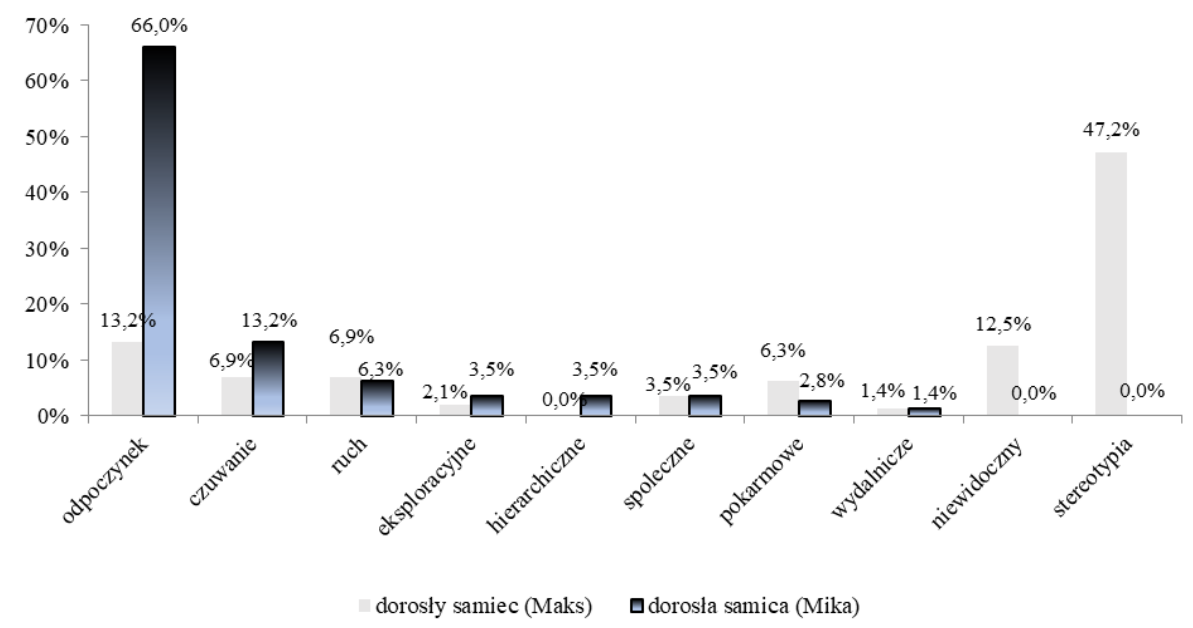

Rys. 2. Porównanie procentowego udziału poszczególnych zachowań dorosłego samca i samicy (test dla proporcji, wartość krytyczna z0,05 $=1,96$ )

Uzyskane wyniki pokazują, że procentowy udział zachowań stereotypowych $\mathrm{u}$ dorosłego samca stanowił niemal połowę wszystkich obserwowanych form aktywności. U młodej samicy stereotypie lokomotoryczne w formie biegania po stałej trasie występowały w zdecydowanie mniejszym nasileniu. Wszystkie osobniki z obserwowanego stada wykazywały największą aktywność w godzinach wieczornych, co jest zgodne z wzorcem gatunkowym. Dotyczyło to również zachowań stereotypowych prezentowanych przez samca. Analizowany przykład wyraźnie wskazuje, iż u wilków szarych długotrwałe przebywanie w ograniczonej przestrzeni powoduje rozwój zaburzeń zachowania, które są trudne do wyeliminowania jedynie za pomocą zwiększenia rozmiaru (i jakości) wybiegu oraz poprawy pozycji socjalnej.

\section{Bibliografia}

Altmann J., 1974. Observational study of behavior sampling methods. Behav. 49, 227-265.

Bashaw M., Kelling A.S., Bloomsmith M., Maple T., 2007. Environmental effects on the behavior of zoo-housed lions and tigers, with a case study of the effects of a visual barrier on pacing. J. Appl. Anim. Welfare Sci. 10, 95-109. https://doi.org/10.1080/10888700701313116

Bashaw M., Tarou L.R., Maki T.S., Maple T., 2001. A survey assessment of variables related to stereotypy in captive giraffe and okapi. Appl. Anim. Behav. Sci. 73, 235-247. https://doi.org/10.1016/S0168-1591(01)00137-X

Bereszynski A., Pietruszczynska M., Jindra I., Wieckowski J., Skrobala D., 1999. Badania porównawcze behawioru wilka (Canis lupus) i psa domowego (Canis familiaris) w warunkach hodowlanych. Rocz. Akad. Rol. Pozn., Zootechnika 51, 27-53.

Bereszyński A., Skrzypczak A., 2002. Wilk w Polsce w warunkach hodowlanych. Wyd. AR w Poznaniu, Poznań, 5-23, 31-44. 
Bernacka H., Nowacka M., Zawiślak J., 2014. Zachowania wilka szarego w niewoli. Prz. Hod. 82(5), 41-45.

Cummings D., Brown J.L., Rodden M.D., Songsasen N., 2007. Behavioral and physiologic responses to environmental enrichment in the maned wolf (Chrysocyon brachyurus). Zoo Biol. 26(5), 331-433. https://doi.org/10.1002/zoo.20138

Fraser D., Weary D.M., Pajor E.A., Milligan B.N., 1997. A scientific conception of animal welfare that reflects ethical concerns. Anim. Welf. 6, 187-205.

Frezard A., Le Pape G., 2003. Contribution to the welfare of captive wolves (Canis lupus lupus): A behavioral comparison of six wolf packs. Zoo Biol. 22(1), 33-44.

Garner J.P., Mason G., Smith R., 2003. Stereotypic tracing in experimentally caged songbirds correlates with general behavioural disinhibition. Anim. Behav. 66, 711-727. https://doi.org/10.1006/anbe.2002.2254

Habel A., Wójcik A., 2011. Ocena dobrostanu wilka (Canis lupus) w Ogrodzie Fauny Polskiej w Bydgoszczy. Ekol. Tech. 19(4), 186-192.

Kaleta T., 2003. Zachowania stereotypowe - charakterystyka i rola w dobrostanie zwierząt. Życie Wet. 78(5), 266-270.

Kania B.F., 2017. Psychofarmakologia zwierząt towarzyszących. Wyd. UR w Krakowie, Kraków.

Kowalski A., 2005. Stereotypie jako wskaźnik dobrostanu zwierząt. Med. Weter. 61(12), 1335-1339.

Kuźniewicz J., Gulda D., 2014. Behawioryzm psowatych. Wyd. UTP w Bydgoszczy, 3-12.

Mason G., 1991. Stereotypies: a critical review. Anim. Behav. 41, 1015-1037. https://doi.org/10.1016/S0003-3472(05)80640-2

Mech L.D., Boitani L., 2003. Wolves: Behavior, ecology, and conservation. Univ. of Chicago Press, Chicago.

Mirecka A., 2013. Standardy prawne a rzeczywisty poziom dobrostanu zwierząt w ogrodach zoologicznych Unii Europejskiej w świetle Dyrektywy Rady 1999/22/WE z dnia 29 marca 1999 r., SWPS, Warszawa, 19-20 listopada 2012. Stud. Ecol. Bioet. 11(2), 177-193.

Okarma H., 1992. Wilk - monografia przyrodniczo-łowiecka. Białowieża, s. 168.

Paquet P.C., Darimon C.T., 2010. Wildlife conservation and animal welfare: two sides of the same coin? Anim. Welf. 19, 177-190.

Passini A., Kaleta T., 1999. Porównanie zachowania się serwala (Leptailurus serval) i ocelota (Leopardus pardalis) w ogrodzie zoologicznym. Przegl. Zool. 43, 161-171.

Rozporządzenie Ministra Środowiska z dnia 16 grudnia 2016 r. w sprawie ochrony gatunkowej zwierząt. Dz.U. z 2016 r., poz. 2183.

Sergiel A., Maślak R., Kusznierz J., Paśko Ł., 2012a. Zachowania stereotypowe - przegląd definicji i klasyfikacji. Med. Weter. 68(1), 45-48.

Sergiel A., Maślak R.,Kusznierz J., Paśko L., 2012b. Stereotypie - rozwój i skutki występowania. Med. Weter. 68(7), 402-405.

Shepherdson D.J., Carlstead K., Mellen J.D., Seidensticker J., 1993. The influence of food presentation on the behavior of small cats in confined environments. Zoo Biol. 12, 203-216.

Singer H.S., 2009. Motor stereotypies. Semin. Pediatr. Neurol. 16, 77-81. https://doi.org/10.1016/ j.spen.2009.03.008

Zimen E., 1981. The Wolf. Souvenir Press, London.

Zimen E., 1982. The wolf pack sociogram. In: Harrington F.H., Paquet P.C. (eds.), Wolves of the world. Noyes, Park Ridge, New Jersey, 282-322.

Złamal A., Kaleta T., 1997. Zachowanie się likaonów (Lycaon pictus Temminck) w ogrodach zoologicznych. Przegl. Zool. 41, 117-123. 
Aneta Krawiec ${ }^{1}{ }^{3}{ }^{\text {, Katarzyna Zdrzałek }}{ }^{1}$, Patrycja Spędzia ${ }^{1}$, Aleksandra Szczepanik ${ }^{1}$, Paweł Żółkiewski ${ }^{2}$, Witold Chabuz ${ }^{2}$, Jan Zdulski ${ }^{2}$

\title{
Adaptacja zwierząt gospodarskich do lokalnych warunków środowiskowych na przykładzie bydła
}

\author{
Adaptation of farm animals to local environmental conditions on example of cattle
}

Adaptacja jest pojemnym terminem używanym w celu opisania zdolności zwierząt do przystosowania się do warunków środowiskowych lub do wnioskowania o modyfikacjach genetycznych, które czynią zwierzęta bardziej zdolnymi do egzystencji w określonych warunkach ekologicznych [Turner 1980]. Adaptację można podzielić na dwie podkategorie: aklimację i aklimatyzację.

Aklimacja jest zmianą fizjologiczną zachodzącą w ciągu życia organizmu, która zmniejsza obciążenie spowodowane eksperymentalnie wywołanymi stresującymi zmianami, w szczególności czynnikami klimatycznymi [Yousef 1985].

Aklimatyzacja także jest zmianą fizjologiczną zachodzącą w ciągu życia, która zmniejsza obciążenie spowodowane przez stresujące zmiany w klimacie naturalnym, takie jak zmiany sezonowe.

Adaptacja do gorącego środowiska może obejmować zmiany fizyczne, behawioralne, fizjologiczne i morfologiczne. Zmiany fizyczne są wynikiem selekcji genetycznej lub cech dziedzicznych przenoszonych z pokolenia na pokolenie [Sharf 2008]. W ciągu ostatnich 12000 lat zwierzęta gospodarskie wykorzystywane do produkcji żywności i w rolnictwie wykształciły się w znaczną liczbę ras dobrze przystosowanych do różnych lokalnych warunków środowiskowych i systemów produkcji. Z biegiem lat, od starożytnej migracji ludzi w poszukiwaniu nowych źródeł żywności po rewolucję przemysłową i najnowsze osiągnięcia technologiczne, promowano rozprzestrzenianie ras dobrze przystosowujących się do warunków klimatycznych na całym świecie [Hammond i in. 1996].

Jak podają Keith i in. [2008], ekologia ewolucyjna ma na celu ocenę wpływu zmian klimatycznych na różnorodność biologiczną w zintegrowanych ramach, które uwzględniają interakcje ekologiczne $\mathrm{w}$ procesach zachodzących $\mathrm{w}$ siedliskach i populacjach, interakcje między gatunkami oraz interakcje między ele-

\footnotetext{
${ }^{1}$ Uniwersytet Przyrodniczy w Lublinie, Wydział Nauk o Zwierzętach i Biogospodarki, Studenckie Koło Naukowe Nauk o Zwierzętach i Biogospodarki, Sekcja Hodowli Bydła

${ }^{2}$ Uniwersytet Przyrodniczy w Lublinie, Wydział Nauk o Zwierzętach i Biogospodarki, Instytut Hodowli Zwierząt i Ochrony Bioróżnorodności

3aneta.krawiec96@gmail.com
} 
mentami demograficznymi i krajobrazowo-klimatycznymi, a także funkcjonowanie społeczności lub ekosystemów. Ramy te koncentrują się zatem na wrażliwości gatunków, na którą z kolei wpływa wrażliwość i ekspozycja gatunków. Wrażliwość jest to stopień, w jakim gatunkowi lub populacji zagrażają zanik, zmniejszenie zdolności do życia, straty genetyczne lub wyginięcie w wyniku zmian klimatu [Williams i in. 2008, Dawson i in. 2011].

Zmienność klimatu może mieć negatywny wpływ na produkcję zwierzęcą z powodu zmniejszonej wydajności reprodukcyjnej, metabolicznej i reakcji immunologicznej [Nardone $\mathrm{i}$ in. 2010]. W związku z tym, aby kontynuować wzrost produkcji mleka i mięsa, w odpowiedzi na negatywne skutki zmian klimatu, a w szczególności stres związany z upałem, konieczna jest selekcja zwierząt odpornych na zmienność klimatu. Booy i in. [2000] zasugerowali wybór populacji, które dobrze radzą sobie w zróżnicowanych warunkach środowiskowych. To takie, które składają się z różnych genotypów, co pozwala im na adaptację środowiskową.

\section{Odporność na pasożyty}

Cechy adaptacyjne do ciepłych klimatów obejmują szeroki zakres funkcji fizjologicznych i cech morfologicznych. Uwzględniają one adaptację do zewnętrznych pasożytów, cechy związane z wymianą ciepła, takie jak straty ciepła przez parowanie i nieodparowywanie oraz wytwarzanie ciepła metabolicznego [Berman 2011]. Pasożyty należą do czynników środowiskowych i mogą wpływać na przetrwanie i wydajność bydła. Ektopasożyty mogą bezpośrednio oddziaływać na zwierzę (np. szkody wyrządza spora ilość kleszczy wypijających krew zwierzęcia). Pośrednie skutki mogą wystąpić, kiedy to ektopasożyty są wektorami chorób, takich jak anaplazmoza, babeszjoza, lub czynników chorobotwórczych przenoszonych np. przez kleszcze [Frisch i in. 2000] czy też muchy tse-tse (przenoszą trypanosom) [Mattioli i in. 2000]. Odporność na kleszcze występuje u niektórych, ale nie wszystkich ras zebu indyjskiego z Azji i Australii [Bock $i$ in. 1999], a odporność na muchę tse-tse nabyły rasy bydła sanga z Afryki [Fivaz i in. 1992]. Odporność genetyczna sprawia, że skóra zwierzęcia jest mniej atrakcyjna dla pasożyta. Zależna od rasy jest, oprócz odporności na kleszcze, także odporność na czynnik chorobotwórczy przenoszony przez nie. Bydło zebu (sahiwal) jest bardziej odporne niż europejskie bydło rasy mlecznej (holsztyńsko-fryzyjskiej) na zakażenie Theileriaannulata [Glass i in. 2005]. Theileria annulata jest pasożytem przenoszonym przez kleszcze, głównie Hyalomma anatolicum. Preston i in. [1992] oraz Glass i in. [2005] potwierdzili odporność zebu, pochodzącego z Pendżabu w Indiach, wobec tego pasożyta poprzez eksperymenty, w których porównano je do bydła rasy holsztyńsko-fryzyjskiej. Podczas badania zarażone eksperymentalnie osobniki bydła tej rasy zmarły, zarażone zaś w ten sam sposób osobniki zebu przeżyły [Jensen i in. 2008]. 


\section{Znaczenie hormonów tarczycy}

W Hiszpanii rodzime bydło kolumbijskie [Pinzón 1991] na przestrzeni wieków zaadoptowało się do środowiska tropikalnego, charakteryzującego się intensywnym promieniowaniem, wysoką temperaturą i wilgotnością, a także słabą jakością paszy i dużym obciążeniem pasożytniczym. Bydło to odznacza się dobrymi cechami reprodukcyjnymi, odpornością i dobrymi właściwościami produkcyjnymi. Uznano, że hormony tarczycy są ważnymi czynnikami w regulacji metabolizmu podstawowego i w procesach fizjologicznych, które są związane $z$ odpornością na ciepło [Campos $i$ in. 2004]. Wykazano różnice w stężeniach hormonów tarczycy we krwi bydła żyjącego w środowisku tropikalnym [Campos 1995]. Zanotowano również związek pomiędzy energią metaboliczną a środowiskiem oraz ustalono parametry fizjologicznych mechanizmów termoregulacji i metabolizmu [McDowell 1978].

W związku z tym przeprowadzono badania na ośmiu rodzimych rasach kolumbijskich występujących w Kolumbii [FAO 1999]. Na podstawie badań stężenia trijodotyroniny (T3) w surowicy krwi i tyroksyny (T4) u bydła krajowego w Kolumbii wykazano (tab. 1), że bydło mleczne innych ras ma wyższe wartości T3, co może sugerować, że rodzime bydło kolumbijskie ma niższy wskaźnik metabolizmu, będący konsekwencją procesu adaptacji.

Surowica T3 u bydła przystosowanego lub prowadzonego w warunkach tropikalnych wykazywała niższe wartości niż u bydła z regionów umiarkowanych, co może wskazywać, że gorące środowisko jest odpowiedzialne za zmniejszone wydzielanie hormonów tarczycy - jest to mechanizm obniżający ciepłotę ciała, jak uważali Campos i Rodas [1999] oraz Velásquez i in. [2000]. Hormony tarczycy odgrywają ważną rolę w regulacji temperatury ciała. W niskiej temperaturze podstawowy metabolizm zwierząt wzmaża wytwarzanie ciepła poprzez zwiększone wydzielanie T3. W wysokiej temperaturze jest odwrotnie [Magdub i in. 1982, Guyton 1989]. Wykazane różnice w stężeniu surowicy T3 wśród kolumbijskich ras rodzimych prawdopodobnie są spowodowane przez różne ekosystemy, w których rodzime zwierzęta żyją od wieków. Najwyższe wartości T3 odnotowano dla ras romosinuano (ROM) i sanmartinero (SAM), które żyją w podobnych warunkach agroekologicznych z najwyższą ilością opadów, co może oznaczać, że łagodzi on stres cieplny. Ponadto są to rasy mięsne, które wymagają mniejszej aktywności metabolicznej niż rasy mleczne [Nixon i in. 1988]. Rodzime rasy mleczne takie jak lucerna (LUC), blanco orejinegro (BON), hartón del valle (HVA) i chino santandereano (CHI) miały podobną wartość surowicy T3. Najniższą zaś zawartość T3 zaobserwowano u rasy casanareno (CAS), która była utrzymywana w najtrudniejszych warunkach żywieniowych (tab. 1).

Poziomy tyroksyny były $\mathrm{w}$ niewielkim stopniu zróżnicowanie pomiędzy grupami rasowymi, prawdopodobnie dlatego, że hormon ten nie jest formą aktywną biologicznie, jednak stanowi ważną rezerwę. Rasa holsztyńsko-fryzyjska i rodzime bydło żyjące na wyżynach tropikalnych mają wyższą wartość T4 niż bydło 
Tabela 1. Stężenia hormonów tarczycy w surowicy krwi w różnych stanach fizjologicznych rodzimych krów kolumbijskich [Campos i in. 2004]

\begin{tabular}{|l|c|c|c|c|c|}
\hline \multirow{2}{*}{ Rasa } & \multirow{2}{*}{$\mathrm{N}$} & \multicolumn{2}{|c|}{ Trijodotyroksyna (nmol/L) } & \multicolumn{2}{c|}{ Tyroksyna (nmol/L) } \\
\cline { 5 - 7 } & & średnio $^{*} \begin{array}{c}\text { odchylenie } \\
\text { standardowe/ SD }\end{array}$ & średnio & $\begin{array}{c}\text { odchylenie } \\
\text { standardowe/ SD }\end{array}$ \\
\hline Blanco orejinegro (BON) & 28 & $1,47^{\mathrm{b}, \mathrm{c}}$ & 0,39 & $55,22^{\mathrm{a}}$ & 14,89 \\
Casanarenho (CAS) & 28 & $1,16^{\mathrm{c}}$ & 0,46 & $53,02^{\mathrm{a}, \mathrm{b}}$ & 18,52 \\
Chino santadereano (CHI) & 28 & $1,48^{\mathrm{b}, \mathrm{c}}$ & 1,73 & $41,88^{\mathrm{c}}$ & 2,19 \\
Costeño con cuernos (CCC) & 28 & $1,74^{\mathrm{b}}$ & 0,44 & $43,43^{\mathrm{b}, \mathrm{c}}$ & 12,28 \\
Hartón del valle (HVA) & 28 & $1,55^{\mathrm{b}, \mathrm{c}}$ & 0,47 & $50,87^{\mathrm{a}, \mathrm{b}, \mathrm{c}}$ & 15,97 \\
Lucerna (LUC) & 28 & $1,58^{\mathrm{b}, \mathrm{c}}$ & 0,62 & $44,96^{\mathrm{b}, \mathrm{c}}$ & 19,18 \\
Romosinuano (ROM) & 28 & $2,85^{\mathrm{a}}$ & 1,46 & $48,62^{\mathrm{a}, \mathrm{b}, \mathrm{c}}$ & 23,77 \\
Sanmartinero (SAM) & 28 & $3,17^{\mathrm{a}}$ & 1,52 & $57,63^{\mathrm{a}}$ & 17,02 \\
\hline
\end{tabular}

Średnie oznaczone róznymi literami różnią się istotnie $(\mathrm{p} \leq 0.05)$

znajdujące się w gorętszych rejonach. Wyższe wartości obserwowano też u ras sanmartinero (SAM) i blanco orejinegro (BON). Najniższą wartość T4 obserwowano u rasy chino santandereano (CHI) [Campos i in. 2004]. Jak pisał we wcześniejszych latach Fuller [1969], aklimatyzacja metaboliczna do wysokich temperatur wiąże się ze zredukowaniem funkcji tarczycy oraz niższego obrotu energią, co w rezultacie prowadzi do stabilności termicznej.

\section{Genetyczne przystosowanie zwierząt do warunków środowiskowych}

Bydło w północno-zachodniej Etiopii jest utrzymywane na wysokości maksymalnej od 550 do $4000 \mathrm{~m}$ n.p.m., co istotnie wpływa na jego zróżnicowanie fenotypowe [Wuletaw i in 2011]. Liczne badania wykazały, że hipoksja wysokościowa prowadzi do nadciśnienia płucnego i stymuluje hematopoezję. Nadciśnienie płucne na dużych wysokościach, zwane też chorobą mostka lub chorobą wysokościową u bydła [Tucker i Rodos 2001], występuje powszechnie na dużych wysokościach w wyniku zmniejszonego nasycenia krwi tlenem, co wpływa na zmniejszenie transportu tlenu do tkanek. W konsekwencji zwierzęta cierpią na stres fizjologiczny z niedotlenienia, który hamuje dyfuzję tlenu z powietrza do płuc [Schmidt-Nielsen 1997]. Parametry krwi są również uważane za ważne wskaźniki w pomiarach adaptacji zwierząt do wysokości.

Wuletaw i in. [2011] badali lokalne rasy północno-zachodniej Etiopii i ich krzyżówki z rasą holsztyńsko-fryzyjską i jersey (tab. 2). W swoich badaniach sprawdzali parametry płucne $\mathrm{i}$ hematologiczne w odniesieniu do adaptacji do dużych wysokości, a w szczególności sposób, w jaki rodzime bydło wysokogórskie reagowało na hipobaryczne niedotlenienie. Brali pod uwagę chorobę wysokościową oraz ciśnienie tętnicy płucnej (PAP), utrzymujące się w normie. Ich 
badania potwierdziły, że zwierzęta przebywające na wysokości 3500 m n.p.m. są do niej genetycznie przystosowane.

Tabela 2. Wyniki PAP (średnia $\pm \mathrm{SD}$ ) badanych zwierząt oznaczone w milimetrach słupa rtęci $(\mathrm{mm} \mathrm{Hg})$ oraz ich położenie [Wuletaw $\mathrm{i}$ in. 2011]

\begin{tabular}{|l|c|c|c|c|}
\hline \multicolumn{1}{|c|}{ Rasa } & $\begin{array}{c}\text { Wysokość } \\
(\mathrm{m})\end{array}$ & $\begin{array}{c}\text { Liczba } \\
\text { obserwacji }\end{array}$ & $\begin{array}{c}\text { Wyniki } \\
\text { PAP, }\end{array}$ & $\begin{array}{c}\text { Zakres } \\
\text { punktacji PAP }\end{array}$ \\
\hline Ogółem & $1730-3500$ & 218 & $33.40 \pm 3.94$ & $21-47$ \\
Ogółem rdzenne & $1730-3500$ & 126 & $33.08 \pm 3.91$ & $21-46$ \\
Fogera & 1730 & 55 & $32.51 \pm 2.95$ & $27-42$ \\
Wegera & 2700 & 39 & $34.41 \pm 3.44$ & $28-42$ \\
Simien & 3500 & 32 & $32.47 \pm 5.36$ & $21-46$ \\
Ogółem mieszańce międzyrasowe & $1730-2700$ & 92 & $33.84 \pm 3.96$ & $28-47$ \\
Fogera $\times$ fryzyjska & 1730 & 8 & $34.50 \pm 2.66$ & $31-39$ \\
Wegera $\times$ fryzyjska & 2700 & 64 & $33.42 \pm 4.15$ & $28-47$ \\
Wegera $\times$ jersey & 2700 & 20 & $35.00 \pm 3.49$ & $30-41$ \\
\hline
\end{tabular}

${ }^{\mathrm{a}}$ ciśnienie w tętnicy płucnej; ${ }^{\mathrm{b}}$ brak istotnych różnic $(\mathrm{p}>0,05) \mathrm{w}$ obrębie jednej kolumny

Tabela 3. Parametry hematologiczne ${ }^{1}$ badanych zwierząt wyrażone jako średnia i odchylenie standardowe (średnia \pm SD) [Wuletaw $i$ in. 2011]

\begin{tabular}{|l|l|l|l|l|l|}
\hline \multicolumn{1}{|c|}{ Rasy } & Wysokość (m) & $\begin{array}{c}\text { Liczba } \\
\text { obserwacji }\end{array}$ & RBC $\left(\times 10^{6} \mu \mathrm{l}\right)$ & HgB $(\mathrm{g} / \mathrm{dl})$ & HCT (\%) \\
\hline Simien & 3500 & 218 & $7,83 \pm 0,83^{\mathrm{a}}$ & $11,24 \pm 1,13^{\mathrm{a}}$ & $33,96 \pm 3,07^{\mathrm{a}}$ \\
Wegera & 2700 & 54 & $6,18 \pm 1,44^{\mathrm{b}}$ & $9,22 \pm 1,65^{\mathrm{b}}$ & $28,21 \pm 4,68^{\mathrm{b}}$ \\
Fogera & 1730 & 37 & $6,62 \pm 0,98^{\mathrm{b}}$ & $9,60 \pm 1,31^{\mathrm{b}}$ & $29,20 \pm 4,59^{\mathrm{b}}$ \\
Metema & 550 & 181 & $6,60 \pm 0,98^{\mathrm{b}}$ & $9,61 \pm 1,31^{\mathrm{b}}$ & $29,20 \pm 4,16^{\mathrm{b}}$ \\
MAC $^{2}$ & 1730 & 98 & $6,50 \pm 1,01^{\mathrm{b}}$ & $9,55 \pm 1,35^{\mathrm{b}}$ & $29,10 \pm 4,22^{\mathrm{b}}$ \\
HAC $^{3}$ & 2700 & 84 & $6,53 \pm 1,41^{\mathrm{b}}$ & $9,71 \pm 1,70^{\mathrm{b}}$ & $29,04 \pm 5,40^{\mathrm{b}}$ \\
Ov ind $^{4}$ & $1730-3500$ & 490 & $6,64 \pm 1,13$ & $9,69 \pm 1,41$ & $29,47 \pm 4,83$ \\
Ov cr $^{5}$ & $1730-2700$ & 182 & $6,05 \pm 1,20$ & $9,61 \pm 1,51$ & $29,05 \pm 4,78$ \\
\hline
\end{tabular}

${ }^{1}$ parametry hematologiczne: $\mathrm{RBC}=$ erytrocyty; $\mathrm{HgB}=$ hemoglobina; $\mathrm{HCT}=$ hematokryt; ${ }^{2}$ krzyżowane na średniej wysokości; ${ }^{3}$ krzyżowane na dużej wysokości; ${ }^{4}$ ogółem rdzenne; ${ }^{5}$ ogółem krzyżowane

Przedstawione wyniki [Wuletaw i in. 2011] wskazują, że w badanych populacjach nie zaobserwowano żadnych objawów choroby mostka. Zwierzęta znajdujące się na dużej wysokości, $3500 \mathrm{~m}$ n.p.m., mają wartości PAP porównywalne z tymi z połowy wysokości, $1730 \mathrm{~m}$ n.p.m. Wszystkie wartości PAP $(21-47 \mathrm{~mm} \mathrm{Hg})$ mieszczą się w zakresie od niskiego do umiarkowanego ryzyka. Różnice w średnich nie były znaczące dla żadnej pary populacji. Krzyżówki lokalnego bydła z holsztyńsko-fryzyjskim i jersey nie były bardziej podatne na chorobę mostkową niż bydło miejscowe mierzone na tych samych wysokościach.

Wuletaw i in. [2011] odnotowali w swoich badaniach różnice w wartościach hematologicznych (tab. 3). Stwierdzili istotny wzrost poziomu $\mathrm{HgB}$, RBC i PCV 
wraz ze wzrostem wysokości, co można uznać za cechę adaptacyjną bydła wysokogórskiego. Znaczące różnice wartości hematologicznych, uwzględniające wysokość i rasy, uzyskali również m.in. Omer i in. [2002] oraz Olayemi i in. [2007]. Bydło simien miało istotnie większe wartości RBC, HgB i HCT niż reszta badanych ras. Badania Hyuna i in. [2007] wykazały, że niedotlenienie na dużych wysokościach powoduje hematopoezję, w której zmniejszone napięcie tlenowe w regionach wysokogórskich prowadzi do wzrostu erytrocytów - jest to mechanizm adaptacyjny do niskiego poziomu tlenu.

\section{Znaczenie okrywy włosowej}

Powszechnie wiadomo, że różne rasy bydła wykazują wyraźne różnice w okrywie włosowej. Są one zgodne z Regułą Wilsona, mówiącej o występowaniu grubej wełnistej okrywie włosowej u zwierząt żyjących w zimnym klimacie i krótkiej okrywie z włosami przylegającymi gładko do skóry u zwierząt żyjących w gorącym klimacie. Kontrast pomiędzy szkockim bydłem górskim a indyjskim bydłem zebu z południowo-wschodniej Azji wyraźnie wskazuje na przystosowanie do zimna i ciepła. W obrębie poszczególnych ras klimat modyfikuje zarówno fenotyp, jak i genotyp charakteru okrywy włosowej [Turner 1964]. Fakt, że genotyp warunkujący rodzaj sierści wydaje się dość szybko zmieniać u ras wprowadzonych do tropików, potwierdza znaczenie tej cechy w kontekście adaptacji. Poszczególnym zwierzętom wyrasta również krótsza okrywa włosowa po przeniesieniu z zimnego do gorącego środowiska nawet na tej samej szerokości geograficznej [Berman i Volcani 1961]. Wykazano, że cielęta z gładko przylegającą sierścią lepiej znoszą ciepło niż cielęta pokryte wełną, nawet jeśli zostały wystrzyżone [Yeates 1955, Turner 1962]. Główną przyczyną tego zjawiska jest związek między rodzajem okrywy włosowej a rozmiarem gruczołu potowego i poziomem jego aktywności [Nay i Dowling 1957, Dowling 1958, Schleger i Turner 1965]. Rodzaj sierści, chociaż zwykle wysoce dziedziczny, jest dość podatny na zmiany pod wpływem składników odżywczych lub czynników patologicznych [Turner 1964]. Futro u bydła żyjącego w klimacie tropikalnym jest jasnej barwy, aby lepiej odbijało promieniowanie słoneczne, co zapobiega $\mathrm{w}$ ten sposób przegrzaniu się zwierzęcia. Sierść przechodzi letnie rozjaśnienie oraz zimowe przyciemnienie, aby odpowiednio zmniejszyć lub zwiększyć ilość przyjmowanego ciepła z promieni słonecznych. Zaobserwowano również, że bydło zwiększa wydzielanie łoju wraz ze stresem cieplnym, co nadaje sierści odbijający i ochronny połysk przed promieniowaniem słonecznym [Brody 1956]. Istnieją dowody na istnienie głównego genu, oznaczonego jako gen gładkich włosów SilkHair (SH), który jest odpowiedzialny za wytwarzenie bardzo krótkiej, gładkiej sierści. Zaobserwowano, że bydło z gładkimi włosami utrzymuje niższe temperatury ciała w porównaniu ze zwierzętami, których futra są bardziej wełniste [Olsen i in. 
2003]. Bydło przechodzi także sezonowe zmiany cech sierści. Zrzuca ono sierść zimową, aby umożliwić lepszą wymianę ciepła [Sharf 2008].

Dowody na istnienie genu wpływającego na tolerancję na ciepło i długość włosów u bydła wykazują Olson i in. [2003]. Uwagę zwraca rasa senepol o krótkiej sierści, która ma korzystniejszą tolerancję na ciepło w porównaniu z bydłem rasy brahman [Hammond i Olson 1994, Hammond i in. 1996]. Krzyżówki bydła senepol z rasami klimatu umiarkowanego wykazują tolerancję na ciepło podobną do krzyżówek bydła brahman i zebu indyjskiego [Hammond i in. 1996, 1998]. Ten ostatni dowód sugeruje, że taki gen występuje w obrębie rasy senepol i że ma on charakter dominacji całkowitej [Jiménez-Cabán i in. 2015]. U bydła senepol gen SH zmapowano na chromosomie 20 [Mariasegaram i in. 2007]. Dalsze badania prowadzone na Florydzie wykazały, że bydło rasy 3/4 holsztyńskiej : 1/4 rasy senepol z fenotypem krótszej sierści (SH) lepiej regulowało swoją równowagę termiczną, gdy było to konieczne, prawdopodobnie poprzez zwiększenie szybkości pocenia się, w porównaniu ze zwierzętami o normalnej sierści (NH) [Dikmen i in. 2008]. W Wenezueli bydło Criollolimonero wykazywało również różnice w obrębie rasy pod względem sierści i chociaż liczba gruczołów potowych na centymetr kwadratowy powierzchni skóry była podobna u samic SH i NH, wielkość gruczołów potowych była większa u tych pierwszych [Landaeta-Hernández $\mathrm{i}$ in. 2011]. Stwierdzono, że rasa senepol, która charakteryzuje się występowaniem $\mathrm{SH}$, ma $89 \%$ europejskiego dziedzictwa rasowego, a mimo to jest dobrze przystosowana do regionów tropikalnych [Flori i in. 2012].

Zwierzęta gospodarskie potrafią doskonale przystosować się do różnego rodzaju warunków środowiskowych. Adaptacja zwierząt jest pojęciem o szerokim znaczeniu. Ciągle prowadzone są badania określające zdolności adaptacyjne zwierząt. Istotny wpływ na problemy z przystosowaniem zwierząt do warunków środowiskowych mają zmiany klimatyczne, w związku z tym należy zwrócić szczególną uwagę na genotypy umożliwiające adaptacje do trudnych warunków środowiska i ich odpowiedni dobór poprzez selekcję. Dlatego kluczową kwestią w hodowli jest zachowanie dużej różnorodności rasowej, co jest podstawą utrzymania i hodowli bydła w różnych warunkach środowiskach na Ziemi, a tym samym podstawą wyżywienia wielu grup społecznych.

\section{Bibliografia}

Berman A., 2011. Invited review: Are adaptations present to support dairy cattle productivity in warm climates? J. Dairy Sci. 94(5), 2147-2158. https://doi.org/10.3168/jds.2010-3962

Berman A., Volcani R., 1961. Seasonal and regional variations in coat characteristics of dairy cattle. Aust. J. Agric. Res. 12, 528-538.

Bock R.E., Kingston T.G., De Vos A.J., 1999. Effect of breed of cattle on innate resistance to infection with Anaplasma marginale transmitted by Boophilus microplus. Aust. Vet. J. 77, 748-751.

Booy G., Hendriks J.J., Smulders M.J.M, Van Groenendael J.M., Vosman B., 2000. Genetic diversity and the survival of populations. Plant Biol. 2, 379-395.

Brody S., 1956. Climatic physiology of cattle. J. Dairy Sci. 39(6), 715-725. 
Campos R., 1995. Triyodotironina, tiroxina y comportamiento reproductivo en diferentes grupos raciales bovinos. Acta Agron. 45, 140-145.

Campos R., Diaz González F.H., Rodas Á., Cruz RC., 2004. Thyroid hormones in native Colombian bovine breeds. Ci. Vet. 11(3), 174-177.

Campos R., Rodas A., 1999. Evaluación de la triyodotironina (T3), tiroxina (T4) y colesterol en cuatro grupos de bovinos Holstein ubicados en sistemas de producción en trópico alto y bajo. Acta Agron. 49, 67-71.

Dawson T.P., Jackson S.T., House J.I., Prentice I.C., Mace G.M., 2011. Beyond predictions: biodiversity conservation in a changing climate. Science 332, 53-58.

Dikmen S., Alava E., Pontes E., Fear J.M., Dikmen B.Y., Olson T.A., Hansen P.J., 2008. Differences in thermoregulatory ability between slick-haired and wild-type lactating Holstein cows in response to acute heat stress. J. Dairy Sci. 91(9), 3395-3402.

Dowling D.F., 1958. The significance of sweating in heat tolerance of cattle. Aust. J. Agric. Res. 9, 579-586.

FAO, 1999. Choosing the conservation strategy. In: Genebanks and the conservation of farm animal genetic resources. Gandini G.C. (ed.). Oldenbroek J.K., Roma.

Fivaz B.H., Waal D.T. de, Lander K., 1992. Indigenous and crossbred cattle: A comparison of resistance to ticks and implications for their strategic control in Zimbabwe. Trop. Anim. Health Prod. 24, 81-89.

Flori L., Gonzatti N.I., Thevenon S., Chantal I., Pinto J., Berthier D., Aso P.M., Gauthier M., 2012. A quasi-exclusive European ancestry in the Senepol tropical cattle breed highlights the importance of the slick locus in tropical adaptation. PloS one 7(5), 1-10.

Frisch J.E., O’Neill C.J., Kelly M.J., 2000. Using genetics to control cattle parasites - The Rockhampton experience. Int. J. Parasitol. 30, 253-264.

Fuller M.F., 1969. Climate and growth. In: Animal Growth and Nutrition, Hafez E.S.E., Dyer JA. Lea and Febiger, Philadelphia.

Glass E.J., Preston P.M., Springbett A., Craigmile S., Kirvar E., Wilkie G., Duncan Brown C.G., 2005. Bos taurus and Bos indicus (Sahiwal) calves respond differently to infection with Theileria annulata and produce markedly different levels of acute phase proteins. Int. J. Parasitol. 35, $337-347$.

Guyton A.C., 1989. Tratado de Fisiología Médica, 7.ed. McGrawHill, México.

Hammond A.C., Olson T.A., 1994. Rectal temperature and grazing time in selected beef cattle breeds under tropical summer conditions in subtropical Florida. Trop. Agric. 71, 128-134.

Hammond A.C., Chase Jr. C.C., Bowers E.J., Olson T.A., Randel R.D., 1998. Heat tolerance in Tuli-, Senepol-, and Brahman-sired Fl Angus heifers in Florida. J. Anim. Sci. 76(6), 1568-1577.

Hammond A.C., Olson T.A., Chase C.C., Bowers E.J., Randel R.D., Murphy C.N., Vogt D.W., Tewolde A., 1996. Heat tolerance in two tropically adapted Bos taurus breeds, Senepol and Romosinuano, compared with Brahman, Angus, and Hereford cattle in Florida. Anim. Sci. J. 74(2), 295-303.

Hyun C., Rhee Y.J., Lee S.A., Lee S.G., Lee S.K., Kim J.T., Song Y.H., 2007. Hematological, blood chemical and hormonal changes in Hanwoo (Korean Native Cattle) raised at different altitudes. J. Vet. Clin. 24, 1-4.

Jensen K., Paxton E., Waddington D., Talbot R., Darghouth M.A., Glass E.J., 2008. Differences in the transcriptional responses induced by Theileria annulata infection in bovine monocytes derived from resistant and susceptible cattle breeds. Int. J. Parasitol. 38, 313-325.

Jiménez-Cabán E., Riera A., Pagan-Morales M., 2015. Correlation of hair length and width with genetic potential for poductive traits in puerto rican holstein cattle. Agrie. Univ. P.R. 99(1), 13-18.

Keith D.A., Akcakaya H.R., Thuiller W., Midgley G.F., Pearson R.G., Phillips S.J., Regan H.M., Araujo M.B., Rebelo T.G., 2008. Predicting extinction risks under climate change: coupling stochastic population models with dynamic bioclimatic habitat models. Biol. Let. 4, 560-563.

Landaeta-Hernández A., Zambrano-Nava S., Hernández-Fonseca J.P., Godoy R., Calles M., Iragorri J.L., Añez L., Polanco M., Montero-Urdaneta M., Olson T., 2011. Variability of hair 
coat and skin traits as related to adaptation in Criollo Limonero cattle. Trop. Anim. Health Pro. 43(3), 657-663.

Magdub A., Johnson H.D., Belyea R.L., 1982. Effect of environmental heat and dietary fiber on thyroid physiology of lactating cows. J. Dairy Sci. 65, 2323-2331.

Mariasegaram M., Chase Jr. C.C., Chaparro J.X., Olson T.A., Brenneman R.A., Niedz R.P., 2007. The slick hair coat locus maps to chromosome 20 in Senepol-derived cattle. Anim. Genet. 38(1), 54-59.

Mattioli R.C., Pandey V.S., Murray M., Fitzpatrick J.L., 2000. Immunogenetic influences on tick resistance in African cattle with particular reference to trypanotolerant N'Dama (Bos taurus) and trypanosusceptible Gobra Zebu (Bos indicus) cattle. Acta Trop. 75, 263-277.

McDowell R.E., 1978. Bases biológicas de la producción animal en zonas tropicales. Acribia, Zaragoza.

Nardone A., Ronchi B., Lacetera N., Ranieri M.S., Bernabucci U., 2010. Effects of climate changes on animal production and sustainability of livestock systems. Livest. Sci. 130, 57-69.

Nay T., Dowling D.F., 1957. Size of sweat glands in Shorthorn strains and Zebu and Shorthorn crossbred cattle. Aust. J. Agric. Res. 8, 385-393.

Nixon D.A., Akasha A., Anderson R.R., 1988. Free and total hormones in serum of Holstein cows. J. Dairy Sci. 71, 1152-1160.

Olayemi F.O., Nwandu C.N., Aiyedun J.O., 2007. Hematology of Sokoto Gudali cattle as influenced by sex and breed. J. Anim. Vet. Adv. 6, 816-818.

Olson T.A., Lucena C., Chase Jr. C.C., Hammond A.C., 2003. Evidence of a major gene influencing hair length and heat tolerance in Bos taurus cattle. J. Anim. Sci. 81(1), 80-90.

Omer O.H., El-Malik K.H., Mahmoud O.M., Haroun E.M., Hawas A., Sweeney D., Magzoub M., 2002. Haematological profiles in pure bred cattle naturally infected with Theileria annulata in Saudi Arabia. Vet. Parasitol. 107, 161-168.

Pinzón E., 1991. Historia de la ganadería bovina colombiana. Santa Fé de Bogotá, Banco Ganadero.

Preston P.M., Brown C.G.D., Bell-Sakyi L., Richardson W., Sanderson A., 1992. Tropical theileriosis in Bos taurus and Bos taurus cross Bos indicus calves: response to infection with graded does of sporozoites of Theileria annulata. Res. Vet. Sci. 53, 230-243.

Schleger A.V., Turner H.G., 1965. Sweating rates of cattle in the field and their reaction to diurnal and seasonal changes. Aust. J. Agric. Res. 16(1), 92-106.

Schmidt-Nielsen K., 1997. Animal Physiology; Adaptation and Environment, 5th ed. Cambridge University Press, London.

Tucker A., Rhodes J., 2001. Role of vascular smooth muscle in the development of high altitude pulmonary hypertension: an interspecies evaluation. High Alt. Med. Biol. 2, 173-189.

Turner H.G., 1962. Effect of clipping the coat on performance of calves in the field. Aust. J. Agric. Res. 13, 180-192.

Turner H.G., 1964. Coat characters of cattle in relation to adaptation. Cattle Research Laboratory, Division of Animal Queensland. Genetics, C.S.I.R.O., Rockhampton.

Turner J.W., 1980. Genetic and biological aspects of Zebu adaptability. J. Anim. Sci. 50, 1201-1205.

Velásquez J.G., Góngora A., Flórez H., Parra J.L., Vanegas O., Cardozo J., González G., 2000. Función tiroidea, progesterona y hematología en post-parto de vacas criollas Sanmartineras del Piedemonte Llanero Colombiano. Rev. Orinoquia 4, 109-122.

Williams S.E., Shoo L.P., Isaac J.L., Hoffmann A.A., Langham G., 2008. Towards an integrated framework for assessing the vulnerability of species to climate change. PLoS Biol. 6, 2621-2626.

Wuletaw Z., Wurzinger M., Holt T., Dessie T., Sölkner J., 2011. Assessment of physiological adaptation of indigenous and crossbred cattle to hypoxic environment in Ethiopia. Livest. Sci. $138,96-104$.

Yeates N.T.M., 1955. Photoperiodicity in cattle. Seasonal changes in coat character and their importance in heat regulation. Aust. J. Agric. Res. 6, 891-902.

Yousef M., 1985. Stress physiology in livestock. 1st ed. CRC Press, Inc., Florida. 
Aneta Krawiec ${ }^{1,3}$, Katarzyna Zdrzałek ${ }^{1}$, Patrycja Spędzia ${ }^{1}$, Aleksandra Szczepanik ${ }^{1}$, Paweł Żółkiewski ${ }^{2}$, Witold Chabuz ${ }^{2}$, Anastasiia Pishchik ${ }^{1}$

\title{
Wpływ czynników środowiskowych na występowanie zapalenia wymienia
}

\author{
The influence of environmental factors on the occurrence of mastitis
}

Czynniki środowiskowe mają istotne znaczenie w rozwoju chorób, ponieważ mogą przyczyniać się do przenoszenia patogenów chorobotwórczych lub wywierać wpływ na żywicieli. W przypadku chorób wywoływanych przez organizmy, które są enzootyczne w gospodarstwach, mogą one mieć mniejsze znaczenie, ale mimo to nadal są ważne w przyczynianiu się do rozwoju chorób [Vasileiou $i$ in. 2019]. Na przykład zwiększone opady deszczu mogłyby doprowadzić do powstawania błotnistych pastwisk, co ograniczałoby wypas zwierząt, a tym samym modyfikowało schematy żywienia. Niskie temperatury zaś doprowadziłyby do zwiększenia zapotrzebowania energetycznego zwierząt, co mogłoby mieć wpływ na stan ich odporności [Caroprese i in. 2015].

Zapalenie wymienia (mastitis) jest jednym z ważniejszych problemów w hodowli krów mlecznych z punktu widzenia ich dobrostanu oraz ekonomiki produkcji mleka. Mimo że w ostatnich latach obserwuje się trend spadkowy w liczbie przypadków mastitis, to jednak pojawia się ono ciągle u $25-45 \%$ zwierząt. Zapalenie wymienia jest chorobą wieloczynnikową, w której otoczenie, patogeny i gospodarz (krowa) wchodzą ze sobą w interakcje [Mainau i in. 2014]. Obecnie zachodzące zmiany w sposobach zarządzania gospodarstwem i środowiskiem, w tym presja społeczna i ekonomiczna, napędzają zmiany w epidemiologii i kontroli mastitis [Klaas i Zadoks 2018].

\section{Etiologia schorzeń gruczołu mlekowego krów}

Zapalenie gruczołu mlekowego objawia się uszkodzeniem tkanek gruczołowych wymienia, które może być wywołane przez mikroorganizmy inwazyjne

\footnotetext{
1 Uniwersytet Przyrodniczy w Lublinie, Wydział Nauk o Zwierzętach i Biogospodarki, Studenckie Koło Naukowe Nauk o Zwierzętach i Biogospodarki, Sekcja Hodowli Bydła

${ }^{2}$ Uniwersytet Przyrodniczy w Lublinie, Wydział Nauk o Zwierzętach i Biogospodarki, Instytut Hodowli Zwierząt i Ochrony Bioróżnorodności, Zakład Hodowli i Ochrony Zasobów Genetycznych Bydła

3 aneta.krawiec96@gmail.com
} 
lub toksygenne i ich toksyny. Wraz z rozwojem stanu zapalnego stają się one dominujące ze względu na zaburzoną równowagę mikrobiologiczną $\mathrm{w}$ gruczole mlekowym. Czynnikami etiologicznymi wywołującymi mastitis są przede wszystkim bakterie, zwłaszcza gronkowce i paciorkowce, a także mikoplazmy, grzyby, algi, pierwotniaki i wirusy. Zapalenie może również rozwijać się w wyniku fizycznego urazu wymienia lub z powodu działania drażniących środków chemicznych [Jones i Bailey 2009].

Dotychczas wyizolowano ponad 150 gatunków drobnoustrojów wywołujących zapalenie wymienia [Kłossowska i Malinowski 2001, Shaheen i in. 2016]. $\mathrm{W}$ analizie stanu zdrowia gruczołu mlekowego istotne jest, by poznać zarówno przyczynę zapalenia, jak i czynnik je wywołujący. Zdaniem Steenevelda i in. [2011] tylko dzięki znajomości patogenów, które wpływają na zapalenie wymion, jesteśmy w stanie zastosować odpowiednią i skuteczną profilaktykę.

Drobnoustroje wywołujące mastitis u krów, w zależności od ich epidemiologicznego powiązania $\mathrm{z}$ chorobą, klasyfikowane są jako patogeny zakaźne (chorobotwórcze) lub środowiskowe [Rossito i in. 2002]. Patogeny zakaźne Staphylococcus aureus i Streptococcus agalactiae oraz mniej powszechne Corynebacterium bovis i Mycoplasma bovis posiadają zdolność do przeżycia w gruczole mlekowym i najczęściej powodują zapalenie, objawiające się m.in. wzrostem liczby komórek somatycznych (LKS). Patogeny środowiskowe z kolei przyczyniają się do wywołania mastitis, jednocześnie nie przystosowując się do przetrwania w organizmie zwierzęcia. Są one najczęściej obecne w najbliższym otoczeniu zwierząt. Do tej grupy zaliczyć można paciorkowce, takie jak Streptococcus dysgalactiae, Streptococcus uberis, Enterococcus spp. oraz pałeczki Escherichia coli, Klebsiella i Enterobacter [Schröder i in. 2005].

Główną przyczyną powstawania reakcji zapalnej w wymieniu są zakażenia bakteryjne i grzybicze. Innymi czynnikami, mającymi wpływ na wywołanie tego schorzenia, są urazy mechaniczne oraz niewłaściwe warunki zoohigieniczne [Malinowski i in. 2003]. Patogeny wywołujące mastitis można podzielić na zakaźne (wśród których najliczniejszą grupę stanowią paciorkowce i gronkowce) lub środowiskowe [Hashemi i in. 2011, Lassa $i$ in. 2013]. Te ostatnie występują $\mathrm{w}$ otoczeniu zwierzęcia, ale nie przystosowują się do przetrwania w jego organizmie [Lassa i in. 2013]. Przez wiele dziesięcioleci określenie „mastitis środowiskowe" (ang. environmental mastitis) było zarezerwowane dla ograniczonej liczby gatunków i rodzajów, zdominowanych przez bakterie z grupy coli i Streptococcus uberis. Obecnie kwestionuje się to postrzeganie na podstawie danych pokazujących, że wiele innych patogenów, w tym Staphylococcus aureus i Streptococcus agalactiae, może pochodzić ze środowiska [Klaas i Zadoks 2018]. Również grzyby i glony zaliczane są do grupy drobnoustrojów środowiskowych. Do czynników decydujących o różnorodności flory mikrobiologicznej mleka należą m.in: wielkość stada, brakowania krów z przewlekłymi stanami mastitis, warunki utrzymania, poziom sanitarny, zarządzanie, wykwalifikowany personel i wiele innych [Klimienè $i$ in. 2011]. 


\section{Rodzaje mastitis}

Jednym z częściej występujących patogenów środowiskowych jest Escherichia coli, która wraz z innymi bakteriami z grupy coli odpowiada za większość klinicznych przypadków zapaleń wymienia. Ze względu na charakterystyczny, ostry przebieg, określono tą formę zapalenia wymienia jako colimastitis. Najczęściej izolowanymi gatunkami poza E. coli są bakterie z rodzajów Klebsiella i Enterobacter.

Zapalenie wywołane przez E. coli jest na ogół przejściowe, a przebieg choroby w dużej mierze zależy od innych czynników, np. etapu laktacji [Burvenich $i$ in. 2003], bilansu energetycznego [Suriyasathaporn i in. 2000], niedoboru witamin [Smith i in. 1997] i stanu szczepien [Bradley i in. 2015].

Streptococcusuberis powoduje zapalenie o charakterze klinicznym. Najczęściej występuje na początku zasuszenia lub we wczesnej laktacji. Stosowanie antybiotyków podczas zasuszenia nie chroni przed zakażeniami tym typem drobnoustrojów, lecz tylko wywołuje pojawienie się stanów zapalnych w okresie okołoporodowym. S. uberis występuje w przewodzie pokarmowym krowy, jest zdolny do namnażania się w środowisku, szczególnie w słomie [Bednarski 2013].

Tabela 1. Gatunki bakterii wyizolowane z próbek mleka krów wielorasowych z klinicznym mastitis po porodzie [Kalmus i in. 2006]

\begin{tabular}{|c|c|c|c|c|}
\hline \multirow{2}{*}{ Patogeny } & \multicolumn{2}{|c|}{ Pierwiastki } & \multicolumn{2}{|c|}{ Wieloródki } \\
\hline & $\%$ & $\mathrm{~N}$ & $\%$ & $\mathrm{n}$ \\
\hline Escherichia coli* & 22,1 & 15 & 6,6 & 20 \\
\hline Streptococcus uberis* & 19,1 & 13 & 9,9 & 30 \\
\hline $\mathrm{CNS}$ & 8,8 & 6 & 7,3 & 22 \\
\hline Lactococcus lactis & 4,4 & 3 & 5 & 15 \\
\hline Klebsiella spp. & 4,4 & 3 & 2,3 & 7 \\
\hline Streptococcus spp. & 2,9 & 2 & 3 & 9 \\
\hline Enterococcus spp. & 2,9 & 2 & 2,3 & 7 \\
\hline Pseudomonas spp. & 2,9 & 2 & 0,7 & 2 \\
\hline Staphylococcus aureus & 1,5 & 1 & 11,2 & 34 \\
\hline Arcanobacterium sp. & 1,5 & 1 & 2,6 & 8 \\
\hline Streptococcus dysgalactiae & 1,5 & 1 & 3,6 & 11 \\
\hline Corynebacterium sp. & 0 & 0 & 2 & 6 \\
\hline Streptococcus agalactiae & 0 & 0 & 3,3 & 10 \\
\hline Candida sp. & 0 & 0 & 1,3 & 4 \\
\hline Brak wzrostu & 25 & 17 & 29,4 & 89 \\
\hline Wzrost mieszany & 2,9 & 2 & 9,6 & 29 \\
\hline Łącznie & 100 & 68 & 100 & 303 \\
\hline
\end{tabular}

* Różnica między pierwiastkami a wieloródkami jest statystycznie istotna dla $S$. uberis $\mathrm{p}=0,037$; bakterii z grupy coli $\mathrm{p}=0,0002$ oraz $S$. aureus $\mathrm{p}=0,019$

Zapalenie gruczołu mlekowego u krów wywołuje również Brucella abortus bovis oraz Br. melitensis. Drobnoustroje te, a szczególnie Br. melitensis, stanowią także przyczynę mastitis u owiec i kóz. Bruceloza wymienia krów ma prze- 
bieg podkliniczny lub kliniczny - przewlekły. Do zakażeń dochodzi na drodze hematogennej, a drobnoustroje umiejscawiają się głównie w tkance śródmiąższowej gruczołu mlekowego. Zakażone krowy i owce ciągle wydalają drobnoustroje z mlekiem [Tittarelli i in. 2005].

Występowanie poszczególnych patogenów przedstawili w swoich badaniach Kalmus $i$ in. [2006]. W tabeli 1 zauważalne są istotne różnice w częstotliwości występowania czynników zapalnych mastitis pomiędzy jałówkami a krowami. Można więc wysunąc wniosek, że jednym z czynników predysponujących do wystąpienia zapalenia wymienia jest wiek zwierzęcia.

\section{Wpływ czynników klimatycznych}

Badania wpływu sezonu na zawartość komórek somatycznych w mleku nie dają jednoznacznej odpowiedzi. W badaniach Lievaart i in. [2007] u krów, których poziom liczby komórek somatycznych (LKS) w mleku nie przekraczał 200 tys. szczyt przypadał w maju i sierpniu, natomiast u zwierząt z LKS > 200000 miało to miejsce $\mathrm{w}$ maju i lipcu. $\mathrm{Z}$ kolei w innych badaniach najwyższe poziomy LKS były stwierdzane we wrześniu, a najniższe w marcu [Riekerink i in. 2007, El-Tahawy i El-Far 2010]. Jednocześnie El-Tahawy i El-Far [2010] stwierdzili, że liczba LKS była największa jesienią i zimą. W przypadku badań Smith i in. [2013] poziom komórek somatycznych w mleku był wręcz niższy w warunkach stresu cieplnego w porównaniu z sytuacją jego braku, a nawet spadał wraz ze wzrostem jego poziomu. Zostało to wykazane zarówno w przypadku rasy holsztyńsko-fryzyjskiej, jak i jersey, a wyniki zostały potwierdzone statystycznie $(\mathrm{p}<0,01)$.

Przeprowadzono badania [Dohoo i Meek 1982] nad wpływem warunków środowiskowych na poziom LKS poprzez umieszczenie krów w komorach z kontrolowanymi warunkami i podniesienie temperatury, jednak nie zakończyły się one powodzeniem, co dodatkowo zaciemnia zrozumienie związku między temperaturą, wilgotnością a liczbą LKS.

Konieczne są więc dalsze badania w celu ustalenia zależności pomiędzy warunkami środowiskowymi (w tym thermal-humidity index) a poziomem komórek somatycznych i przypadkami mastitis. Pojawiła się nawet teza, że wysoka temperatura i wilgotność mogą ograniczać rozwój flory wywołującej zapalenie wymienia. Potwierdza to, że związek pomiędzy klimatem a mastitis jest złożony [Smith i in. 2013].

Podobnie jak w przypadku bydła, tak również u owiec mastitis jest chorobą wieloczynnikową, w której wiele bakterii zidentyfikowano jako czynniki sprawcze i wiele elementów składa się na potencjalne predyspozycje do zachorowania [Gelasakis i in. 2015, Fthenakis i in. 2017].

Vasileiou i in. [2019] prowadzili badania dotyczące wpływu czynników środowiskowych (tab. 2) na występowanie zapalenia wymienia u owiec w Grecji. Wykazali oni związek niektórych czynników klimatycznych z występowaniem mastitis. W szczególności były to parametry związane $\mathrm{z}$ temperaturą: średnia 
roczna temperatura $(p=0,050)$, średni dobowy zakres temperatur $(p=0,033)$, minimalna temperatura najzimniejszego miesiąca $(\mathrm{p}=0,031)$, roczny zakres temperatur $(\mathrm{p}=0,029)$, a także średnia roczna prędkość wiatru $(\mathrm{p}<0,001)$. Istotny był również czynnik lokalizacyjny, a konkretnie typ mikrosiedliska na tym obszarze $(\mathrm{p}=0,001)$.

Tabela 2. Wpływ warunków środowiskowych na mastitis u owiec [Vasileiou i in. 2019]

\begin{tabular}{|c|c|c|c|}
\hline Zmienna & Źródło & $\begin{array}{c}\text { Średnia } \\
( \pm \text { błąd } \\
\text { standardowy }) \\
\end{array}$ & $\mathrm{p}^{*}$ \\
\hline Średnia roczna temperatura $\left({ }^{\circ} \mathrm{C}\right)$ & $\begin{array}{l}\text { Baza danych } \\
\text { WorldClim }^{\text {a }}\end{array}$ & $16,0 \pm 0,1$ & 0,050 \\
\hline Średni dobowy zakres temperatur $\left({ }^{\circ} \mathrm{C}\right)$ & $\begin{array}{l}\text { Baza danych } \\
\text { WorldClim }^{\text {a }}\end{array}$ & $9,9 \pm 0,2$ & 0,033 \\
\hline $\begin{array}{l}\text { Maks. temperatura najcieplejszego } \\
\text { miesiąca }\left({ }^{\circ} \mathrm{C}\right)\end{array}$ & $\begin{array}{l}\text { Baza danych } \\
\text { WorldClim }^{\text {a }} \\
\end{array}$ & $31,6 \pm 0,2$ & 0,162 \\
\hline $\begin{array}{l}\text { Min. temperatura najzimniejszego } \\
\text { miesiąca }\left({ }^{\circ} \mathrm{C}\right)\end{array}$ & $\begin{array}{l}\text { Baza danych } \\
\text { WorldClim }^{\mathrm{a}}\end{array}$ & $3,2 \pm 0,3$ & 0,031 \\
\hline Zakres roczny temperatury $\left({ }^{\circ} \mathrm{C}\right)$ & $\begin{array}{l}\text { Baza danych } \\
\text { WorldClim }{ }^{\text {(a) }}\end{array}$ & $28,5 \pm 0,4$ & 0,029 \\
\hline $\begin{array}{l}\text { Srednia temperatura na } 30 \mathrm{dni} \\
\text { przed datą pobrania próbki }\left({ }^{\circ} \mathrm{C}\right)\end{array}$ & $\begin{array}{l}\text { Baza danych } \\
\text { WorldClim }^{\text {a }}\end{array}$ & $16,3 \pm 0,7$ & 0,071 \\
\hline Całkowite roczne opady $(\mathrm{mm})$ & $\begin{array}{l}\text { Baza danych } \\
\text { WorldClim }^{\text {a }} \\
\end{array}$ & $650,5 \pm 13,8$ & 0,356 \\
\hline Średnia roczna prędkość wiatru $\left(\mathrm{m} \mathrm{s}^{-1}\right)$ & ArcGIS-HRAE $^{b}$ & $4,1 \pm 0,1$ & $<0,001$ \\
\hline $\begin{array}{l}\text { Średnia prędkość wiatru na } 30 \text { dni } \\
\text { przed datą próbkowania }\left(\mathrm{m} \mathrm{s}^{-1}\right)\end{array}$ & ArcGIS-HRAE ${ }^{b}$ & $7,9 \pm 0,3$ & 0,190 \\
\hline Wysokość (m) & DEM $^{c}$ & $181,1 \pm 14,4$ & 0,081 \\
\hline $\begin{array}{l}\text { Odległość od małych ferm } \\
\text { przeżuwaczy }(\mathrm{m})\end{array}$ & ArcGIS-GPACAP ${ }^{\mathrm{d}}$ & $332,6 \pm 21,2$ & 0,920 \\
\hline Odległość od agencji zdrowia publicznego (m) & ArcGIS-GPACAP $^{\mathrm{d}}$ & $8288,4 \pm 398,6$ & 0,047 \\
\hline
\end{tabular}

* p wyprowadzony w analizie modelu jednoimiennego

${ }^{a}$ http://www.worldclim.org; ${ }^{b}$ www.rae.gr; ${ }^{\mathrm{c}}$ http://srtm.csi.cgiar.org/Index.asp; ${ }^{\mathrm{d}} \mathrm{http}: / /$ www.opekepe.gr; http://www.statistics. gr

Ostatecznie Vasileiou i in. [2019] wykazali, że determinującymi czynnikami środowiskowymi zwiększonego występowania subklinicznego zapalenia wymienia są najniższa temperatura najzimniejszego miesiąca (asocjacjacja ujemna) oraz średnia temperatura $\mathrm{w}$ okresie poprzedzającym pobieranie próbek (asocjacjacja dodatnia).

Według El-Tarabany i in. [2017] wysokie temperatury środowiskowe mogą prowadzić do zmniejszenia liczby leukocytów u owiec. W takich przypadkach leukocyty mają upośledzoną funkcję [Lecchi i in. 2016]. Z racji tego, że mają one bardzo istotną rolę w ochronie owiec przed mastitis, ich zmniejszona liczba i nieefektywność przyczyniłyby się do zwiększenia częstości jego występowania 
$\mathrm{w}$ gospodarstwach $\mathrm{z}$ ekstremalnymi poziomami temperatury. Istnieją bowiem dowody wskazujące na to, że $\mathrm{w}$ podwyższonej temperaturze krowy częściej zapadają na mastitis [Arcaro i in. 2013].

\section{Dój i jego higiena}

Nieodpowiednie wykorzystanie urządzeń udojowych jest głównym czynnikiem zwiększającym występowanie subklinicznego mastitis [Hristov i Anojčić 1998]. Wynika to $\mathrm{z}$ tego, że wszelkie zaniedbania w zakresie higieny mleka, dojarzy, środowiska i urządzeń udojowych, jak również ich techniczna dokładność mają pierwszorzędne znaczenie $\mathrm{w}$ występowaniu chorób wymion, a tym samym również w jakości mleka [Hristov i in. 2002].

Dezynfekcja strzyków oraz kubków udojowych po każdym doju, konserwacja dojarek, obmywanie wymion pod ciepłą, bieżącą wodą i wstępnymi środkami higieniczno-sanitarnymi zmniejszają ilość przyrostu nowych zapaleń. Ponadto warunki higieniczne doju, prawidłowa obsługa, regularna dezynfekcja hali udojowej mają znaczący wpływ na stan zdrowia wymion krów [Hristov i in. 2002].

Wykrywanie mastitis (również w fazie podklinicznej) w trakcie doju może odbywać się także w nowoczesnych systemach tj. AMS - automatic milking systems, na podstawie m.in. przewodności mleka. Test przewodności elektrycznej bazuje na różnicach $\mathrm{w}$ koncentracji soli w mleku z chorych oraz zdrowych ćwiartek. Przy wystąpieniu mastitis wzrasta przewodność elektryczna ze względu na wzrost $\mathrm{Na}^{+} \mathrm{i} \mathrm{Cl}^{-}$oraz spadek $\mathrm{K}^{+}$i laktozy. W przypadku mleka pochodzącego ze zdrowych ćwiartek przewodność waha się pomiędzy $4,0-5,5 \mathrm{mS} / \mathrm{cm}$ [Spakauskas i in. 2006]. Oprócz tego parametru systemy udojowe, a w szczególności systemy doju automatycznego bazują na opatentowanych algorytmach do wykrywania mastitis opartych również na pomiarze temperatury mleka, barwie mleka, spadku wydajności itp. [https://www.epo.org/law-practice/case-lawappeals/recent/t111670eu1.html].

\section{Material ściołowy}

Najważniejszymi czynnikami ryzyka wystąpienia zapalenia wymienia zidentyfikowanymi w raporcie opublikowanym przez Europejską Agencję ds. Bezpieczeństwa Żywności [EFSA 2009] są niewłaściwa higiena ściółki (szczególnie w przypadku patogenów środowiskowych) oraz źle zaprojektowany, używany lub utrzymywany sprzęt do dojenia (ze względu na patogeny zakaźne). Otoczenie krowy (legowisko, wybieg i hale udojowe) powinny być czyste, suche i dobrze wentylowane [Mainau i in. 2014].

Zapobieganie mastitis środowiskowemu opiera się m.in. na zmniejszeniu ekspozycji strzyków i zapewnieniu higieny wymion. Bydło mleczne spędza od 
12 do $14 \mathrm{~h}$ na dobę w pozycji leżącej, a w tym czasie strzyki są stale narażone na potencjalne patogeny w środowisku [Tucker i Weary 2004].

Materiał ściółkowy w obszarze leżenia zawsze zawiera różne ilości różnych bakterii, na które narażone są krowie wymiona i strzyki. Częstotliwość występowania mastitis środowiskowego jest skorelowana z liczbą bakterii na końcach strzyków [Hogan i in. 1989]. Z kolei liczba bakterii na końcu strzyku jest ściśle powiązana z liczbą bakterii w ściółce [Rendos i in. 1975]. Użycie nieorganicznych podłoży, takich jak piasek, skutkowało obecnością mniejszych ilości patogenów wywołujących środowiskowe mastitis $\mathrm{w}$ ściółce $\mathrm{w}$ porównaniu $\mathrm{z}$ organicznymi ściołami, takimi jak trociny [Fairchild i in. 1982, Hogan i in. 1989]. Ilości kału i moczu oraz zawartość suchej masy w ściółce są również ważne w rozprzestrzenianiu się bakterii [Zdanowicz i in. 2004]. Liczbę bakterii w podłożu organicznym można zredukować poprzez stosowanie wapna oraz alkalicznych lub kwaśnych środków odkażających, które wpływają na pH ściołów [Hogan i Smith 1997, Hogan i in. 1999, 2007].

Wieloletnie badania można podsumować następująco. Stwierdzono dużą liczbę CNS (coagulase-negative staphylococci, m.in. paciorkowców) we wszystkich typach ściółek i na strzykach krów na nich utrzymywanych, przy czym najmniejszą ich liczbę wyizolowano z mleka krów utrzymywanych na świeżym piasku i głęboko ścielonym separacie z gnojowicy (tab. 3). W przypadku świeżego piasku stwierdzono także mniejszą zachorowalność na mastitis wywoływane przez bakterie gramujemne (w tym podgrupy bakterii Coli i Klebsiella spp.). Duża liczba paciorkowców we wszystkich typach ściółek stanowi potencjalne ryzyko subklinicznego mastitis z podwyższonym poziomem komórek somatycznych. $Z$ kolei najniższa liczba wszystkich kategorii bakterii gram-ujemnych w świeżym piasku stanowi najmniejsze ryzyko klinicznego zapalenia. Wśród krów utrzymywanych na tym podłożu było również mniej przypadków subklinicznych z dodatnimi posiewami. W pozostałych grupach nie zauważono znaczących różnic [Rowbotham i Ruegg 2015, Rowbotham i Ruegg 2016]. W tym samym stadzie wykazano jednak, że rodzaj ściołów wpływał na czystość wymion, a czystość wymion na liczbę bakterii na skórze. Co ciekawe, w większości przypadków (poza świeżym piaskiem) przednie i tylne strzyki charakteryzowały się podobnym poziomem bakterii na skórze, natomiast krowy częściej zapadały na kliniczne mastitis strzyków przednich. Nie wykazano zależności pomiędzy kształtem strzyków, a liczbą bakterii na skórze, natomiast spośród wszystkich ocenianych cech liniowych wymienia na poziom bakterii na skórze okazało się wpływać tylko ustawienie strzyków tylnych, liczebność bakterii była większa wraz z bliżej siebie położonymi strzykami [Guarín i in. 2017].

Podsumowując, warunki środowiskowe mają niewątpliwie istotny wpływ na występowanie zapalenia wymienia. Stosowanie się do zasad higieny oraz stworzenie krowom odpowiednich warunków życia sprawia, że problem mastitis znacząco się zmniejsza. Znając patogeny i czynniki środowiskowe wywołujące zapalenie wymienia, możemy wypracować doskonały system profilaktyki prze- 
Tabela 3. Wpływ rodzaju ściołów na występowanie mastitis i podłoże epidemiologiczne [Rowbotham i Ruegg 2016]

\begin{tabular}{|c|c|c|c|c|c|c|}
\hline \multirow[b]{2}{*}{$\begin{array}{l}\text { Wzrost mikrobiologiczny } \\
\text { (n) }\end{array}$} & \multicolumn{4}{|c|}{ Ścioły } & \multirow[b]{2}{*}{ Ogółem } & \multirow[b]{2}{*}{$\%$} \\
\hline & $\begin{array}{l}\text { świeży } \\
\text { piasek }\end{array}$ & $\begin{array}{c}\text { piasek } \\
\text { z recyklingu }\end{array}$ & $\begin{array}{l}\text { głęboko } \\
\text { ścielony } \\
\text { separat } \\
\text { z gnojowicy }\end{array}$ & $\begin{array}{c}\text { separat } \\
\text { z gnojowicy ścielony } \\
\text { na materacach } \\
\text { z rdzeniem } \\
\text { piankowym }\end{array}$ & & \\
\hline $\begin{array}{l}\text { Incydentalne podkliniczne } \\
\text { mastitis }\end{array}$ & 13 & 17 & 18 & 18 & 66 & \\
\hline $\mathrm{CNS}$ & 1 & 6 & 1 & 6 & 14 & 23,7 \\
\hline $\begin{array}{l}\text { Środowiskowe } \\
\text { Streptococcus spp. }\end{array}$ & 1 & 0 & 0 & 0 & 1 & 1,7 \\
\hline Corynebacterium spp. & 0 & 1 & 0 & 0 & 1 & 1,7 \\
\hline Staphylococcus ureus & 0 & 0 & 0 & 1 & 1 & 1,7 \\
\hline Nieokreślony wzrost & 11 & 8 & 16 & 7 & 42 & 71,2 \\
\hline Brak próbki & 0 & 1 & 0 & 3 & 4 & \\
\hline Zanieczyszczone próbki & 0 & 1 & 1 & 1 & 3 & \\
\hline $\begin{array}{l}\text { Nawracające podkliniczne } \\
\text { mastitis }\end{array}$ & 14 & 19 & 19 & 17 & 69 & \\
\hline $\mathrm{CNS}$ & 2 & 7 & 3 & 7 & 19 & 29,7 \\
\hline $\begin{array}{l}\text { Środowiskowe } \\
\text { Streptococcus spp. }\end{array}$ & 1 & 0 & 0 & 0 & 1 & 1,6 \\
\hline Staphylococcus ureus & 0 & 0 & 0 & 1 & 1 & 1,6 \\
\hline Nieokreślony wzrost & 10 & 12 & 15 & 6 & 43 & 67,2 \\
\hline Zanieczyszczone próbki & 1 & 0 & 1 & 3 & 5 & \\
\hline Incydentalne kliniczne mastitis & 3 & 9 & 5 & 4 & 21 & \\
\hline $\mathrm{CNS}$ & 0 & 2 & 0 & 1 & 3 & 18,8 \\
\hline $\begin{array}{l}\text { Środowiskowe } \\
\text { Streptococcus spp. }\end{array}$ & 0 & 1 & 0 & 0 & 1 & 6,3 \\
\hline Staphylococcus ureus & 0 & 0 & 0 & 1 & 1 & 6,3 \\
\hline Escherichia coli & 0 & 0 & 3 & 0 & 3 & 18,8 \\
\hline Klebsiella spp. & 0 & 1 & 0 & 0 & 1 & 6,3 \\
\hline Grzyby & 0 & 1 & 0 & 0 & 1 & 6,3 \\
\hline Brak lub nieokreślony wzrost & 3 & 1 & 1 & 1 & 6 & 37,5 \\
\hline Zanieczyszczone próbki & - & 3 & 1 & 1 & 5 & \\
\hline
\end{tabular}

ciw tej chorobie. Aby było to możliwe, należy jednak pamiętać, że trzeba wziąć pod uwagę wszystkie aspekty związane z zarządzaniem gospodarstwem oraz $\mathrm{z}$ ciągłymi zmianami środowiskowymi.

\section{Bibliografia}

Arcaro J.R.P., Matarazzo S.V., Pozzi C.R., Arcaro J.I., Toledo L., Costa E.O., Miranda M.S., 2013. Effects of environmental modification on mastitis occurrence and hormonal changes in Holstein cows Pesqui. Vet. Bras. 33, 826-830.

Bednarski M., 2013. Choroby bydła, podstawy diagnostyki i terapii. Apra-wetpress s.c., Myślęcinek. 
Bradley A.J., Breen J.E., Payne B., White V., Green M.J., 2015. An investigation of the efficacy of a polyvalent mastitis vaccine using different vaccination regimens under field conditions in the United Kingdom. J. Dairy Sci. 98(3), 1706-1720.

Burvenich C., Merris V., Mehrzad J., Diez-Fraile A., Duchateau L., 2003. Severity of E. coli mastitis is mainly determined by cow factors. Vet. Res. 34(5), 521-564.

Caroprese M., Giannenas I., Fthenakis G.C., 2015. Interactions between nutritional approaches and defences against microbial diseases in small ruminants. Vet. Microbiol. 181, 8-14.

Dohoo I.R., Meek A.H., 1982. Somatic cell counts in bovine milk. Can. Vet. J. 23, 119-125.

EFSA, 2009. Scientific opinion on welfare of dairy cows in relation to udder problems based on a risk assessment with special reference to the impact of housing, feeding, management and genetic selection. The EFSA J. 1141, 1-60.

El-Tahawy A.S., El-Far A.H., 2010. Influences of somatic cell count on milk composition and dairy farm profitability. Int. J. Dairy Technol. 63, 463-469.

El-Tarabany M.S., El-Tarabany A.A., Atta M.A., 2017. Physiological and lactation responses of Egyptian dairy Baladi goats to natural thermal stress under subtropical environmental conditions. Int. J. Biometeorol. 61, 61-68.

Fairchild T.P., McArthur B.J., Moore J.H., Hylton W.E., 1982. Coliform counts in various bedding materials. J. Dairy Sci. 65, 1029-1035.

Fthenakis GC., Barbagianni M.S., Fragkou I.A., Gougoulis D.A., Katsafadou A.I., Mavrogianni V.S., Petridis I.G., Vasileiou N.G.C., 2017. Elucidation of predisposing factors for ovine mastitis contributes to sustainable control of the disease. Handbook of 9th International Sheep Veterinary Congress, Harrogate, United Kingdom, pp. 60.

Gelasakis A.I., Mavrogianni V.S.,Petridis I.G., Vasileiou N.G.C., Fthenakis G.C., 2015. Mastitis in sheep - the last 10 years and the future of research. Vet. Microbiol. 185, 136-146.

Guarín J.F., Baumberger C., Ruegg P.L., 2017. Anatomical characteristics of teats and premilking bacterial counts of teat skin swabs of primiparous cows exposed to different types of bedding. J. Dairy Sci. 100(2), 1436-1444.

Hashemi M., Kafi M., Safdarian M., 2011. The prevalence of clinical and subclinical mastitis in dairy cows in thecentral region of Fars province, south of Iran. Iranian J. Vet. Res. 12, 236-241.

Hogan J.S., Wolf S.L., Petersson Wolfe C.S., 2007. Bacterial counts in organic materials used as free-stall bedding following treatment with commercial conditioner. J. Dairy Sci. 90, 1058-1062.

Hogan J.S., Smith K.L., 1997. Bacterial counts in sawdust bedding. J. Dairy Sci. 80, 1600-1605.

Hogan J.S., Bogacz V.L., Thompson L.M., Romig S., Schoenberger P.S., Weiss W.P., Smith. K.L., 1999. Bacterial counts associated with sawdust and recycled manure bedding treated with commercial conditioners. J. Dairy Sci. 82, 1690-1695.

Hogan J.S., Smith K.L., Hoblet K.H., Todhunter D.A., Schoenberger P.S., Hueston W.D., Pritchard D.E., Bowman G.L., Heider L.E., Brockett B. L., Conrad H.R., 1989. Bacterial counts in bedding materials used on nine commercial dairies. J. Dairy Sci. 72, 250-258

Hristov S., Anojčić B., 1998. Prilog poznavanju učestalosti pojavljivanja i mera sprečavanja pojave mastitisa kod krava. Arhiv poljopr. nauke 1-2, 73-83.

Hristov S., Relić R., Stanković B., 2002. Failures in conveying hygienic procedures during milking of cows. J. Agric. Sci. 47(2), 233-240.

https://www.epo.org/law-practice/case-law-appeals/recent/t111670eu1.html [dostęp: 21.03.2020].

Jones G.M., Bailey T.L., 2009. Understanding the basics of mastitis. Virginia Cooperative Extension. Virginia Tech, Blacksburg.

Kalmus P., Viltrop A., Aasmäe B., Kask K., 2006. Occurrence of clinical mastitis in primiparous Estonian dairy cows in different housing conditions. Acta Vet. Scand. 48(1), 21.

Klaas I.C., Zadoks R.N., 2018. An update on environmental mastitis: challenging perceptions. Transbound. Emerg. Dis. 65, 166-185.

Klimienė I., Ružauskas M., Špakauskas V., Mockeliūnas R., Pereckienè A., ButrimaitėAmbrozevičienė $\check{C}$., 2011. Preva-lence of gram positive bacteria in cow mastitis and their susceptibility to beta-lactam antibiotics. Vet. Med. Zootech. 56, 65-72. 
Kłossowska A., Malinowski E., 2001. Drobnoustroje patogenne dla człowieka w mleku zbiorczym. Med. Weter. 57, 28-33.

Lassa H., Kubiak J., Małkińska-Horodyska M., 2013. Bakterie najczęściej izolowane z klinicznych postaci mastitis u krów oraz ich wrażliwość na antybiotyki. Życie Wet. 88(8), 651-653.

Lecchi C., Rota N., Vitali A., Ceciliani F., Lacetera N., 2016. In vitro assessment of the effects of temperature on phagocytosis, reactive oxygen species production and apoptosis in bovine polymorphonuclear cells. Vet. Immunol. Immunopathol. 182, 89-94.

Lievaart, J.J., Barkema H.W., Kremer W.D.J., Broek J. van den, Verheijden J.H.M., Heesterbeek J.A.P., 2007. Effect of herd characteristics, management practices, and season on different categories of the herd somatic cell count. J. Dairy Sci. 90, 4137-4144.

Mainau E., Temple D., Manteca X., 2014. Welfare issues related to mastitis in dairy cows. FAWEC. [online:] http://www.fawec.org/media/com_lazypdf/pdf/fs10-en.pdf [dostęp: 22.10.2020].

Malinowski E., Kłossowska A., Kaczmarski M., Kuźma K., 2003. Prevalance of intramammary infections in pregnant heifers. Bull. Vet. Inst. Puławy 47, 165-170.

Riekerink R.O., Barkema H.W., Stryhn H., 2007. The effect of season on somatic cell count and the incidence of clinical mastitis. J. Dairy Sci. 90, 1704-1715.

Rendos J.J., Eberhart R.J., Kesler E.M., 1975. Microbial populations on the teat ends of the dairy cows and bedding materials. J. Dairy Sci. 58, 1492-1500.

Rossito P.V., Ruiz L., Kikuchi Y., Glenn K., Luiz K., Watts J.L., Cullor J.S., 2002. Antibiotic susceptibility patterns for environmental streptococci isolated from mastitis in central California dairies. J. Dairy Sci. 85, 132-138.

Rowbotham R.F., Ruegg P.L., 2015. Association of bedding types with management practices and indicators of milk quality on larger Wisconsin dairy farms. J. Dairy Sci. 98, 7865-7885.

Rowbotham R.F., Ruegg P.L., 2016. Associations of selected bedding types with incidence rates of subclinical and clinical mastitis in primiparous Holstein dairy cows. J. Dairy Sci. 99, 4707-4717.

Schröder A., Hoedemaker M., Klein G., 2005. Resistance of mastitis pathogens in northern Germany. Berl. Munch. Tierarztl. Wochenschr. 118, 393-398.

Shaheen M., Tantary H. A., Nabi S.U., 2016. A treatise on bovine mastitis: Disease and disease economics, etiological basis, risk factors, impact on human health, therapeutic management, prevention and control strategy. J. Adv. Dairy Res. 4, 1-10.

Smith K.L., Hogan J.S., Weiss W.P., 1997. Dietary vitamin E and selenium affect mastitis and milk quality. J. Anim. Sci. 75(6), 1659-1665.

Smith D.L., Smith T., Rude B.J., Ward S.H., 2013. Short communication: Comparison of the effects of heat stress on milk and component yields and somatic cell score in Holstein and Jersey cows. J. Dairy Sci. 96, 3028-3033.

Spakauskas V., Klimiene I., Matusevicius A., 2006. A comparison of indirect methods for diagnosis of subclinical mastitis in lactating dairy cows. Veterinarskiarhiv 76(2), 101-109.

Steeneveld W., Werven T. van, Barkema H.W., Hogeveen H., 2011. Cow-specific treatment of clinical mastitis: an economic approach. J. Dairy Sci. 94, 174-188.

Suriyasathaporn W., Heuer C., Noordhuizen-Stassen E.N., Schukken Y.H., 2000. Hyperketonemia and the impairment of udder defense: A review. Vet. Res. 31(4), 397-412.

Tittarelli M., Diventura M., De Massis F., Scacchia M., Giovannini A., Nannini D., Caporale V., 2005. The persistence of Brucella melitensis in experimentally infected ewes through three reproductive cycles. J. Vet. Med. 52, 403-409.

Tucker C.B., Weary D.M., 2004. Bedding on geotextile mattresses: How much is needed to improve cow comfort? J. Dairy Sci. 87(9), 2889-2895.

Vasileiou N.G.C., Giannakopoulosa A., Crippsb P.J., Ioannidia K.S., Chatzopoulosa D.C., Gougoulisa D.A., Billinisa C., Mavrogiannia V.S., Petinakic E., Fthenakisa G.C., 2019. Study of potential environmental factors predisposing ewes to subclinical mastitis in Greece. Comp. Immunol. Microbiol. Infect. Dis. 62, 40-45.

Zdanowicz M., Shelford J.A., Tucker C.B., Weary D.M., Keyserlingk M.A.G. von, 2004. Bacterial populations on teats ends of dairy cows housed in free stalls and bedded with either sand or sawdust. J. Dairy Sci. 87, 1694-1701. 
Aneta Krawiec ${ }^{1}$, Piotr Domaradzki ${ }^{2},{ }^{5}$, Piotr Skałecki $^{2}$, Paweł Żółkiewski ${ }^{3}$,

Piotr Stanek ${ }^{3}$, Mariusz Florek ${ }^{3}$, Michał Prasow ${ }^{3}$, Marek Kowalczyk ${ }^{3}$, Agnieszka Kaliniak-Dziura ${ }^{3}$, Edyta Kowalczuk-Vasilev ${ }^{4}$, Katarzyna Zdrzałek ${ }^{1}$

\title{
Wpływ dodatku siemienia Inianego $w$ dawkach pokarmowych cieląt odsadków rasy limousine na wartość rzeźną i skład chemiczny mięsa
}

\author{
Influence of linseed in Limousin calves diets on slaughter value and meat quality
}

Zwierzęta rasy limousine są najliczniejszą rasą bydła mięsnego użytkowanego w Polsce. Do głównych walorów tej rasy zaliczyć należy bardzo duży udział mięśni w tuszy i jednocześnie niską obecność tłuszczu. Umożliwia to prowadzenie intensywnego opasu do wysokiej masy końcowej, bez nadmiernego otłuszczenia czy pogorszenia jakości tuszy. $Z$ tego też względu bydło limousine jest szczególnie cenione przez przemysł mięsny [Florek i in. 2013].

Jakość mięsa wołowego kształtowana jest już na etapie chowu zwierząt rzeźnych, jednak wiele czynników przyżyciowych i poubojowych wpływa na jego końcową jakość. Istotne znaczenie wśród czynników przedubojowych odgrywają uwarunkowania genetyczne i pozagenetyczne, takie jak: rasa, płeć, wiek oraz system chowu, żywienie i obrót przedubojowy [Domaradzki i in. 2016]. Spośród ww. czynników istotną rolę odgrywa żywienie, w tym jego intensywność mająca duży wpływ na wartość rzeźną i jakość mięsa [Wajda 2001, Oprządek 2011]. Najważniejszym parametrem określającym wartość rzeźną bydła jest wskaźnik wydajności rzeźnej (poubojowej), czyli stosunek masy tuszy do masy przedubojowej oraz udział chudego mięsa w tuszy, będący istotnym wskaźnikiem wartości handlowej tuszy [Florek i in. 2013].

\footnotetext{
1 Uniwersytet Przyrodniczy w Lublinie, Wydział Nauk o Zwierzętach i Biogospodarki, Studenckie Kolo Naukowe Nauk o Zwierzętach i Biogospodarki, Sekcja Hodowli Bydła

${ }^{2}$ Uniwersytet Przyrodniczy w Lublinie, Wydział Nauk o Zwierzętach i Biogospodarki, Instytut Oceny Jakości i Przetwórstwa Produktów Zwierzęcych

3 Uniwersytet Przyrodniczy w Lublinie, Wydział Nauk o Zwierzętach i Biogospodarki, Instytut Hodowli Zwierząt i Ochrony Bioróżnorodności

${ }^{4}$ Uniwersytet Przyrodniczy w Lublinie, Wydział Nauk o Zwierzętach i Biogospodarki, Instytut Żywienia Zwierząt i Bromatologii

${ }^{5}$ piotr.domaradzki@up.lublin.pl

* Prace zrealizowano z projektu finansowanego w ramach programu Ministra Nauki i Szkolnictwa Wyższego pod nazwą „Regionalna Inicjatywa Doskonałości” w latach 2019-2022, nr projektu 029/RID/2018/19, kwota finansowania $11927330 \mathrm{zł}$.
} 
Aktualnie użytkowym przeznaczeniem mięsa cielęcego jest mięso kulinarne. $\mathrm{Na}$ świecie cielęcina pozyskiwana jest od zwierząt w wieku od kilku do 48 tygodni życia. W Polsce klasyczna cielęcina pochodzi od zwierząt karmionych mlekiem lub preparatami mlekozastępczymi i ubijanych w młodszym wieku (7-8 tyg.). W niektórych krajach (zwłaszcza Europie Zachodniej) utrzymujących dużą populację bydła ras mięsnych, ubojowi poddaje się cielęta w wieku 7-8 miesięcy, a niekiedy nawet starsze - w wieku do 12 miesięcy. Dzięki temu w relatywnie krótkim (jak na bydło) okresie, tj. jednego roku kalendarzowego można uzyskać bardzo cenny surowiec charakteryzujący się znaczną wydajnością rzeźną, przy maksymalnym wykorzystaniu naturalnych zasobów paszowych. Należy również zauważyć, że maksymalny wiek dla tej kategorii zwierząt w Unii Europejskiej nie powinien przekraczać 8 miesięcy, bez względu na sposób ich żywienia [Domaradzki i in. 2017].

Mięso cielęce uzyskane od zwierząt odchowanych razem z matkami w systemie pastwiskowym zawiera wartościowe i funkcjonalne składniki odżywcze, niezbędne w utrzymaniu zdrowia człowieka zarówno w sferze fizycznej, jak i psychicznej. Prozdrowotne właściwości takiej cielęciny są efektem wysokiej zawartości białka, witamin, kwasów PUFA, w tym izomerów CLA, kwasu linolowego i $\alpha$-linolenowego, korzystnej proporcji kwasów n-6:n-3, jak również niskiej zawartości thuszczu i cholesterolu [Domaradzki 2018].

$\mathrm{Na}$ znaczne zwiększenie potencjału produkcyjnego zwierząt gospodarskich wpłynął postęp genetyczny, jaki dokonał się w ostatnich latach. Aktualnie zwierzęta charakteryzują się wysoką produkcyjnością, przy jednocześnie wzrastających wymaganiach zarówno żywieniowych, jak i dotyczących utrzymania [Dzwonkowski 2016]. Przyczynia się to do wzrostu znaczenia rodzaju i formy materiałów paszowych, które są stosowane w żywieniu zwierząt wysokoprodukcyjnych. Warunkują one odpowiednią koncentrację energii, a także innych składników pokarmowych w dawkach, jednocześnie wpływając na skład i jakość pozyskiwanych produktów odzwierzęcych. Ma to znaczenie priorytetowe zwłaszcza z punktu widzenia konsumenta. Do najczęściej stosowanych sposobów poprawy koncentracji energii w dawkach dla zwierząt gospodarskich należą dodatki tłuszczów pochodzenia roślinnego, m.in. nasion roślin oleistych (np. lnu), olejów roślinnych oraz tłuszczów chronionych [Gubała 2004, Barowicz 2011, Klebaniuk i in. 2012]. Nasiona roślin oleistych oraz oleje roślinne są źródłem składników odżywczych, energii, a także wpływają na jakość pozyskiwanego surowca [Klebaniuk i in. 2012].

\section{Len w żywieniu przeżuwaczy}

Len jest rośliną oleistą uprawianą głównie na północnych Wielkich Równinach w USA i w Kanadzie [Berglund i Zollinger 2002]. Tradycyjnie nasiona lnu są miażdżone w celu produkcji oleju lnianego do konsumpcji oraz oleju do dal- 
szego wykorzystania w przemyśle. Powstały makuch lniany jest wykorzystywany jako suplement białkowy w paszach dla zwierząt gospodarskich. Len zawiera około 20\% kwasu alfa-linolenowego (ALA) w suchej masie. ALA to niezbędny nienasycony kwas thuszczowy (NNKT) należący do rodziny omega-3. Kwas ALA jest prekursorem długołańcuchowych wielonienasyconych kwasów thuszczowych tj. eikozapentaenowego (EPA) i dokozaheksanowego (DHA), pełniących bardzo istotne funkcje w organizmie człowieka. Kwas EPA jest prekursorem dla eikozanoidów, będącymi związkami podobnymi do hormonów, które odgrywają istotną rolę w odpowiedzi immunologicznej [Maddock i in. 2005]. $\mathrm{Z}$ kolei kwas DHA jest niezbędny do zapewnienia integralności błon komórkowych, również także zdrowia mózgu i oczu [Conners 2000].

Znaczące wykorzystanie siemienia lnianego jako środka zwiększającego wartość energetyczną pasz nastąpiło niedawno i to głównie ze względu na wysoką zwartość kwasu alfa-linolenowego, co potencjalnie pozwala również zwiększyć zawartość kwasów tłuszczowych omega-3 w mleku i mięsie. Jednakże zakres wzrostu zawartości kwasów omega-3 w tych produktach jest ograniczony ze względu na szeroką biohydrogenację wielonienasyconych kwasów tłuszczowych w żwaczu przed ich wchłonięciem [Doreau i Ferlay 2015].

Według Klebaniuk i in. [2012] współczesne metody żywienia zwierząt opasowych pozwalają na modyfikowanie nie tylko stosunku tłuszczowo-mięsnego, ale również udziału i wzajemnej proporcji NNKT. Z większości badań wynika, że wpływ rasy na zawartość kwasów tłuszczowych jest niewielki, a rozbieżności wynikają ze zróżnicowanego sposobu żywienia. Jak stwierdzili Zymon i Strzetelski [2010], żywienie jest najważniejszym sposobem modyfikacji jakości mięsa i tłuszczu, a także zawartości poszczególnych rodzajów kwasów thuszczowych w mięsie wołowym. Wyższy udział zielonki pastwiskowej w dawce pokarmowej wpływa na obniżenie w tłuszczu śródmięśniowym zawartości kwasów nasyconych (SFA) oraz na podwyższenie zawartości kwasów jedno- i wielonienasyconych (MUFA i PUFA). Podobny lub nawet bardziej wzmocniony efekt można uzyskać, stosując dodatkowo do mieszanki treściwej dla bydła opasowego dodatek nasiona lnu oleistego. Nasiona roślin oleistych oraz oleje roślinne są bardzo istotnym składnikiem w dawkach pokarmowych dla zwierząt rzeźnych. Są źródłem składników odżywczych, energii, a także są czynnikiem wpływającym na jakość prozdrowotną mięsa pozyskiwanego od tych zwierząt [Klebaniuk i in. 2012].

Nie bez znaczenia pozostaje również stosowanie lnu w dawkach pokarmowych dla krów. Jak stwierdzili Casper i in. [1990] oraz Petit [2003], żywienie nasionami lnu krów mlecznych jest jedną z metod zwiększania udziału kwasów nienasyconych $\mathrm{w}$ mleku. Udział wielonienasyconych kwasów tłuszczowych $\mathrm{w}$ mleku można dodatkowo zwiększyć poprzez proces ekstruzji nasion lnu [Akraim i in. 2007]. Według Jensena [2002] szczególną uwagę należy zwrócić na możliwości podwyższania zawartości w mleku sprzężonego kwasu linolowego CLA i kwasu trans-wakcenowego. To właśnie produkty mleczne są dla człowieka głównym 
źródłem CLA. Dawki bogate w kwas linolowy czy linolenowy, a także oleinowy (zwłaszcza oparte na zielonce pastwiskowej i nasionach roślin oleistych) sprzyjają podwyższonej zawartości tych kwasów w mleku [Dhiman i in. 2000].

\section{Wpływ żywienia Inem na jakość i wartość rzeźną mięsa}

W Instytucie Oceny Jakości i Przetwórstwa Produktów Zwierzęcych we współpracy z pracownikami Instytutu Hodowli Zwierząt i Ochrony Bioróżnorodności oraz Instytutu Żywienia Zwierząt i Bromatologii Uniwersytetu Przyrodniczego w Lublinie prowadzone sa badania dotyczace wpływu dodatku siemienia lnianego w dawkach pokarmowych dla cieląt odsadków rasy limousine na wartość rzeźną i jakość ich mięsa. Badania te prowadzone są w ramach projektu „Systemy produkcji i pakowania żywności zapewniające zachowanie jej bioaktywnych składników ważnych w profilaktyce chorób cywilizacyjnych" realizowanego w ramach Regionalnej Inicjatywy Doskonałości (Nr 029/RID/2018/19). W niniejszej pracy przedstawiono wstępne wyniki badań z 2019 r.

Materiał badawczy stanowiło 12 cieląt utrzymywanych przy matkach do 7-8 miesiąca życia, które losowo podzielono na dwie grupy: doświadczalną (LM Len) otrzymującą w mieszance treściwej len odmiany Szafir, w ilości 6\% suchej masy dawki oraz kontrolną (LM Kont.) - żywioną paszami bez dodatku lnu. W czasie doświadczenia określano masę ciała i dobowe przyrosty cieląt, a po uboju wartość rzeźną tusz (masę, wydajność poubojową, uformowanie i otłuszczenie tusz według EUROP, pomiary liniowe oraz udział podstawowych elementów) oraz skład chemiczny mięśnia najdłuższego grzbietu ( $m$. longissimus lumborum - LL) i półścięgnistego ( $m$. semitendinosus - ST).

Cielęta z grupy kontrolnej (LM Kont) w trakcie doświadczenia osiągały wyższe $(\mathrm{p}<0,05)$ przyrosty dobowe $(1294 \mathrm{~g} /$ dobę $) \mathrm{w}$ stosunku do grupy doświadczalnej (LM Len) żywionej mieszanką treściwą z dodatkiem lnu (1123 g/dobę). W efekcie tego grupa LM Kont. uzyskała o $46 \mathrm{~kg}$ wyższą masę ciała $\mathrm{w}$ momencie uboju oraz o $29,7 \mathrm{~kg}$ wyższą masę tuszy ciepłej, a różnice te zostały potwierdzone statystycznie $-\mathrm{p}<0,05$ (tab. 1). W przypadku pozostałych parametrów, tj. uformowania i otłuszczenia tuszy oraz ubytku chłodniczego, nie stwierdzono istotnych różnic pomiędzy ocenianymi grupami cieląt, aczkolwiek cielęta $\mathrm{z}$ grupy żywionej $\mathrm{z}$ dodatkiem siemienia lnianego zostały ocenione wyżej pod kątem umięśnienia (84\% tusz w klasie U i 16\% w klasie O vs. $67 \%$ w klasie U i $33 \%$ w klasie R), odznaczały się mniejszym otłuszczeniem tusz oraz mniejszym ubytkiem chłodniczym $(2,84 \%$ vs. $2,96 \%)$ - tabela 1 .

Badania nad wpływem m.in. dodatku siemienia lnianego w żywieniu cieląt rasy rubia gallega prowadzone były przez González i in. [2014]. Cielęta ubijane były nieco później, bo ok. 10 miesiąca życia, a ich masa ubojowa wynosiła 356 $\mathrm{kg}$, natomiast masa tuszy ciepłej $182 \mathrm{~kg}$. W stosunku do badań własnych cielęta osiągnęły zatem niższą wydajność rzeźną ciepłą wynoszącą 50,0\%. Średnie 
uformowanie tuszy zostało określone na 7,7, a otłuszczenie 7,8 pkt. Z kolei He $i$ in. [2011] nie wykazali wpływu stosowania nasion oleistych na przyrosty dzienne cieląt, masę półtusz, wydajność rzeźną oraz uformowanie tuszy w stosunku do grupy kontrolnej nie otrzymującej takiego dodatku.

Tabela 1. Wskaźniki wartości rzeźnej ocenianych cieląt

\begin{tabular}{|c|c|c|c|}
\hline Wyróżniki & LM Len & LM Kont. & Ogółem \\
\hline Przyrosty dobowe masy ciała (g) & $1123^{\mathrm{a}} \pm 126$ & $1294^{\mathrm{b}} \pm 133$ & $1202 \pm 130$ \\
\hline Masa ciała przed ubojem $(\mathrm{kg})$ & $282^{\mathrm{a}} \pm 37$ & $328^{\mathrm{b}} \pm 21$ & $306 \pm 32$ \\
\hline Masa tuszy ciepłej (kg) & $172,8^{\mathrm{a}} \pm 18,7$ & $202,5^{\mathrm{b}} \pm 23,1$ & $187,2 \pm 21,0$ \\
\hline Wydajność rzeźna ciepła (\%) & $61,3 \pm 2,2$ & $61,5 \pm 1,9$ & $61,4 \pm 1,8$ \\
\hline Ubytek chłodniczy tusz (\%) & $2,84 \pm 0,40$ & $2,96 \pm 0,31$ & $2,92 \pm 0,34$ \\
\hline Klasyfikacja EUROP & \multirow{2}{*}{$\mathrm{U}-84 \% ; \mathrm{O}-16 \%$} & \multirow{2}{*}{$U-67 \% ; R-33 \%$} & \\
\hline Uformowanie tuszy & & & \\
\hline Otłuszczenie tuszy & $1-33 \% ; 2-67 \%$ & $1-16 \% ; 2-84 \%$ & \\
\hline
\end{tabular}

Średnie oznaczone różnymi literami w wierszach różnią się istotnie: $\mathrm{a}, \mathrm{b}-\mathrm{p}<0,05$

Cielęta z grupy doświadczalnej (LM Len) w stosunku do grupy kontrolnej odznaczały się istotnie $(p<0,05)$ mniejszą szerokością klatki piersiowej $(03,65 \mathrm{~cm})$ oraz długością udźca (o $4,40 \mathrm{~cm})$. W przypadku pozostałych wyróżników tj. długości tuszy i lędźwi oraz obwodu udźca nie obserwowano istotnych różnic $-\mathrm{p}<0,05$ (tab. 2).

Tabela 2. Pomiary liniowe $(\mathrm{cm})$ półtusz ocenianych cieląt

\begin{tabular}{|l|c|c|c|}
\hline \multicolumn{1}{|c|}{ Wyróżniki } & LM Len & LM Kont. & Ogółem \\
\hline Długość tuszy & $111,00 \pm 3,53$ & $115,00 \pm 6,05$ & $112,33 \pm 4,72$ \\
Szerokość klatki piersiowej & $52,35^{\mathrm{a}} \pm 2,47$ & $56,00^{\mathrm{b}} \pm 2,24$ & $53,57 \pm 2,92$ \\
Długość lędźwi & $45,35 \pm 2,19$ & $46,00 \pm 1,87$ & $45,57 \pm 2,04$ \\
Długość udźca & $62,00^{\mathrm{a}} \pm 1,89$ & $66,40^{\mathrm{b}} \pm 3,05$ & $63,47 \pm 3,09$ \\
Obwód udźca & $87,75 \pm 5,95$ & $94,10 \pm 7,92$ & $89,87 \pm 7,09$ \\
\hline
\end{tabular}

Średnie oznaczone różnymi literami w wierszach różnią się istotnie: $a, b-p<0,05$

Rozpatrując udział elementów zasadniczych w tuszy (tab. 3), istotne różnice stwierdzono $\mathrm{w}$ przypadku zawartości udźca $\mathrm{z}$ golenią, którego masa $\mathrm{w}$ grupie cieląt żywionych z dodatkiem lnu wynosiła $32,46 \mathrm{~kg}$, a w grupie kontrolnej $38,52 \mathrm{~kg}$. Podobną zależność obserwowano dla łaty ze szpondrem i mostkiem oraz łopatki z golenią - masa tych elementów tuszy w grupie doświadczalnej wyniosła odpowiednio $16,88 \mathrm{~kg}$ i 14,87 kg, natomiast w grupie LM kont. 20,60 kg oraz $17,46 \mathrm{~kg}$. Różnice te zostały potwierdzone statystycznie przy $\mathrm{p} \leq 0,05$. Warto zauważyć, że tusze cieląt z grupy LM Len charakteryzowały się istotnie 
większym procentowym udziałem polędwiczki (2,41\% vs. $2,19 \%)$ przy zbliżonym udziale masowym tego elementu w obu grupach $\mathrm{W}$ przypadku pozostałych elementów nie obserwowano istotnych różnic pomiędzy grupami. Należy jednak zauważyć, że elementy pozyskane $\mathrm{z}$ rozbioru tusz cieląt żywionych mieszanką treściwą $\mathrm{z}$ dodatkiem lnu były lżejsze, co było konsekwencją niższej masy tusz w tej grupie zwierząt.

Tabela 3. Wyniki rozbioru półtusz ocenianych cieląt na elementy zasadnicze

\begin{tabular}{|l|c|c|c|c|c|c|}
\hline \multirow{2}{*}{\multicolumn{1}{|c|}{$\begin{array}{c}\text { Elementy } \\
\text { tuszy }\end{array}$}} & \multicolumn{2}{|c|}{ LM Len } & \multicolumn{2}{c|}{ LM Kont. } & \multicolumn{2}{c|}{ Ogółem } \\
\cline { 2 - 7 } & $\mathrm{kg}^{1}$ & $\%^{2}$ & $\mathrm{~kg}^{1}$ & $\%^{2}$ & $\mathrm{~kg}^{1}$ & $\%^{2}$ \\
\hline Karkówka \\
z rozbratlem & $10,57 \pm 1,19$ & $11,88 \pm 0,61$ & $12,22 \pm 2,42$ & $11,52 \pm 0,98$ & $11,12 \pm 1,80$ & $11,76 \pm 0,74$ \\
Antrykot & $4,63 \pm 1,00$ & $5,16 \pm 0,76$ & $5,30 \pm 1,35$ & $4,99 \pm 0,73$ & $4,85 \pm 1,13$ & $5,11 \pm 0,73$ \\
Łata & & & & & & \\
ze szpondrem & $16,88^{\mathrm{a}} \pm 2,14$ & $18,94 \pm 1,06$ & $20,60^{\mathrm{b}} \pm 2,14$ & $19,62 \pm 1,05$ & $18,12 \pm 2,75$ & $19,17 \pm 1,07$ \\
i mostkiem & & & & & & \\
Łopatka & $14,87^{\mathrm{a}} \pm 1,85$ & $16,66 \pm 0,51$ & $17,46^{\mathrm{b}} \pm 1,52$ & $16,64 \pm 0,58$ & $15,73 \pm 2,11$ & $16,65 \pm 0,51$ \\
z golenią & $6,83 \pm 0,88$ & $7,75 \pm 0,48$ & $8,14 \pm 1,36$ & $7,81 \pm 0,52$ & $7,27 \pm 1,20$ & $7,77 \pm 0,47$ \\
Rostbef & $32,46^{\mathrm{a}} \pm 4,90$ & $36,26 \pm 1,51$ & $38,52^{\mathrm{b}} \pm 4,06$ & $36,66 \pm 1,49$ & $34,48 \pm 5,37$ & $36,39 \pm 1,46$ \\
Udziec & & $2,41^{\mathrm{b}} \pm 0,19$ & $2,19 \pm 0,23$ & $2,09^{\mathrm{a}} \pm 0,13$ & $2,16 \pm 0,25$ & $2,30 \pm 0,23$ \\
z golenią & $2,15 \pm 0,26$ & $1,28 \pm 0,10$ & $1,35 \pm 0,13$ & $1,30 \pm 0,07$ & $1,20 \pm 0,22$ & $1,29 \pm 0,09$ \\
Polędwiczka & $1,15 \pm 0,22$ & 1,23 \\
Ogon & & & & & & \\
\hline
\end{tabular}

${ }^{1}$ zawartość elementu w tuszy $\mathrm{w} \mathrm{kg} ;{ }^{2}$ procentowy (\%) udział elementu w tuszy; średnie oznaczone różnymi literami w wierszach różnią się istotnie: $\mathrm{a}, \mathrm{b}-\mathrm{p} \leq 0,05$

Analizując skład chemiczny i wartość energetyczną mięśnia najdłuższego grzbietu i półścięgnistego cieląt (tab. 4), stwierdzono większą zawartość białka w grupie cieląt żywionych lnem w stosunku do grupy kontrolnej, odpowiednio $23,13 \%$ vs. $21,96 \%$ w mięśniu LL i $22,51 \%$ vs. $21,75 \%$ w ST. Mięśnie cieląt $\mathrm{z}$ grupy LM Len odznaczały się również niższym udziałem tłuszczu, wyższym udziałem popiołu oraz wyższą wartością energetyczną, aczkolwiek wyniki te nie zostały potwierdzone statystycznie $-\mathrm{p}<0,05$. Stwierdzone $w$ badaniach własnych wartości są zbliżone do wyników badań Florka i in. [2007] przeprowadzonych na młodym bydle rzeźnym rasy PHF. Z kolei González i in. [2014] $\mathrm{w}$ mięsie cieląt rasy rubia gallega żywionych $\mathrm{z}$ dodatkiem siemienia lnianego oznaczyli niższą niż w badaniach własnych zawartość białka - 21,06\%, natomiast zdecydowanie wyższą zawartość tłuszczu - 3,01\%.

Podsumowując, należy stwierdzić, iż cielęta $\mathrm{z}$ grupy LM Len w porównaniu z cielętami z grupy LM Kont. charakteryzowały się niższymi przyrostami dobowymi, mniejszą masą ciała przed ubojem oraz mniejszą masą tuszy po uboju. Przełożyło się to na istotnie mniejszą szerokość klatki piersiowej i długość udźca 
Tabela 4. Skład podstawowy (\%) oraz wartość energetyczna (kcal/100 g) mięśni cieląt odsadków rasy limousine

\begin{tabular}{|l|c|c|c|c|}
\hline \multirow{2}{*}{ Wyróżniki } & \multicolumn{2}{|c|}{ m. logissimus lumborum } & \multicolumn{2}{c|}{ m. semitendinosus } \\
\cline { 2 - 5 } & LM Len & LM Kont. & LM Len & LM Kont. \\
\hline Woda & $74,76 \pm 0,74$ & $75,23 \pm 1,05$ & $75,28 \pm 0,50$ & $75,81 \pm 0,65$ \\
Białko & $23,13^{\mathrm{b}} \pm 0,68$ & $21,96^{\mathrm{a}} \pm 1,19$ & $22,51^{\mathrm{B}} \pm 0,24$ & $21,75^{\mathrm{A}} \pm 0,60$ \\
Tłuszcz & $0,64 \pm 0,10$ & $0,75 \pm 0,06$ & $0,72 \pm 0,21$ & $0,83 \pm 0,26$ \\
Popiół & $1,23 \pm 0,08$ & $1,05 \pm 0,44$ & $1,29 \pm 0,21$ & $1,26 \pm 0,02$ \\
Wartość energetyczna & $98,29 \pm 2,04$ & $94,61 \pm 4,59$ & $96,51 \pm 2,15$ & $94,50 \pm 3,14$ \\
\hline
\end{tabular}

Średnie oznaczone różnymi literami w wierszach, $w$ obrębie danego mięśnia, różnią się istotnie: $a, b-p<0,05$; $\mathrm{A}, \mathrm{B}-\mathrm{p} \leq 0,01$

$\mathrm{w}$ tej grupie cieląt oraz niższą masę takich elementów tuszy jak udziec z golenią, łata ze szpondrem i mostkiem oraz łopatka $\mathrm{z}$ golenią. Jednakże tusze cieląt żywionych mieszanką treściwą z dodatkiem siemienia lnianego (LM Len) odznaczały się istotnie większym udziałem polędwiczki, a ich mięso zawierało więcej białka.

\section{Bibliografia}

Akraim F., Nicot M.C., Juaneda P., Enjalbert F., 2007. Conjugated linolenic acid (CLnA), conjugated linolein acid (CLA) and other biohydrogenation intermediates in plasma and milk fat of cows fed raw or extruded linseed. Animal 1(6), 835-843.

Barowicz T., 2011. Tłusta dieta. Hoduj z głową. Bydło 1, 20-24.

Berglund D.R., Zollinger R.K., 2002. Flax production in North Dakota. North Dakota State University Extension Service Bulletin A-1038.

Casper D.P., Schingoethe D.J., Eisenbeisz W.A., 1990. Response of early lactation cows to diets that vary in ruminal degradability of carbohydrates and amount of fat. J. Dairy Sci. 73, 425-444.

Conners W.E., 2000. Importance of n-3 fatty acids in health and disease. Am. J. Clin. Nutr. 71, $171-175$.

Dhiman T.R., Satter L.D., Pariza M.W., Galli M.P., Albright K., Tolosa M.X., 2000. Conjugated linoleic acid (CLA) content of milk from cows offered diets rich in linoleic and linolenic acid. J. Dairy Sci. 83, 1016-1027.

Domaradzki P., Florek M., Litwińczuk A., 2016. Czynniki kształtujące jakość mięsa wołowego. Wiad. Zootech. 2, 160-170.

Domaradzki P., Stanek P., Litwińczuk Z.,Skałecki P., Florek M., 2017. Slaughter value and meat quality of suckler calves: A review. Meat Sci. 134, 135-149.

Domaradzki P., 2018. Właściwości fizykochemiczne i wartość odżywcza mięsa buhajków 5 ras, w tym 3 objętych programem ochrony zasobów genetycznych. Rozprawa habilitacyjna. Uniwersytet Przyrodniczy w Lublinie, Lublin.

Doreau M., Ferlay A., 2015. Linseed: a valuable feedstuff for ruminants. OCL 22(6) D611.

Dzwonkowski W., 2016. Analiza sytuacji na krajowym rynku pasz białkowych w kontekście ewentualnego zakazu stosowania materiałów paszowych gmo. Instytut Ekonomiki Rolnictwa i Gospodarki Żywnościowej, PIB w Warszawie.

Florek M., Litwińczuk Z., Litwińczuk A., Skałecki P., Domaradzki P., Ryszkowska-Siwko M., 2013. Wartość rzeźna cieląt mlecznych i 6-8-miesięcznych odsadków ras mięsnych. Prz. Hod. 3, $15-17$. 
Florek M., Litwińczuk Z., Kędzierska-Matysek M., Grodzicki T., Skałecki P., 2007. Wartość odżywcza mięsa z lędźwiowej części mięśnia najdłuższego i półścięgnistego uda młodego bydła rzeźnego. Med. Weter. 63(2), 242-246.

González L., Moreno T., Bispo E., Dugan M.E., Franco D., 2014. Effect of supplementing different oils: linseed, sunflower and soybean, on animal performance, carcass characteristics, meat quality and fatty acid profile of veal from "Rubia Gallega" calves. Meat Sci. 96, 829-836.

Gubała A., 2004. Tłuszcz w żywieniu zwierząt przeżuwających. Hod. Bydła 9, 14-18.

He M., Mir P., Sharma R., Schwartzkopf-Genswein K., Entz T., Travis G., Dugan M., Rolland D., Okine E., Dodson M., 2011. Effect of supplementation of beef steer diets with oil con-taining $\mathrm{n} 6$ and $\mathrm{n} 3$ fatty acids and $48 \mathrm{~h}$ feed withdrawal treatments on animal productivity, carcass characteristics and fatty acid composition. Livest. Sci. 142, 253-263.

Jensen R.G., 2002. The composition of bovine milk lipids. J. Dairy Sci. 85, 295-350.

Klebaniuk R., Kowalczuk-Vasilev E., Czech A., 2012. Len w żywieniu zwierząt. Uniwersytet Przyrodniczy w Lublinie.

Maddock T.D., Anderson V.L. Lardy G.P., 2005. Using Flax in Livestock Diets. NDSU Extension Service. AS-1283.

Oprządek J., 2011. Ocena jakości mięsa wołowego. Prz. Hod. 4, 13-16.

Petit H.V., 2003. Digestion, milk production, milk composition, and blood composition of dairy cows fed formaldehyde treated flaxseed or sunflower seed. J. Dairy Sci. 86, 2637-2646.

Wajda S., 2001. Możliwości poprawy jakości mięsa wołowego. Gosp. Mięs. 7, 24-26.

Zymon M., Strzetelski J., 2010. Sposoby poprawy właściwości prozdrowotnych mięsa bydlęcego. Wiad. Zootech. 48(4), 53-63. 


\author{
Marlena Księżarczyk ${ }^{1,4}$, Paulina Leśniak ${ }^{2}$, Marcin Bartłomiej Arciszewski ${ }^{3}$, \\ Jose Luis Valverde Piedra ${ }^{2}$
}

\title{
Wykorzystanie metody kometkowej do identyfikacji uszkodzeń struktury DNAerytrocytów gęsi po ekspozycji na $\mathbf{C d C l}_{2}$ in vitro*
}

\author{
The use of comet assay method for the detection of DNA-damage \\ in geese erytrocytes after exposure to $\mathrm{CdCl} 2$ in vitro
}

\begin{abstract}
Wstęp
Metoda kometkowa (elektroforeza pojedynczych jąder komórkowych w żelu agarozowym) to metoda badawcza, która umożliwia wykrycie uszkodzeń struktury DNA w komórkach jądrzastych. Do przeprowadzenia testu kometkowego wykorzystuje się wiele rodzajów komórek pochodzących nie tylko od ssaków, ptaków czy ryb, ale również od roślin, bezkręgowców czy grzybów [Cotelle i Ferard 1999, Tice i in. 2000, Peggy i Banath 2006, Pellegri i in. 2019]. Metoda ta po raz pierwszy została opisana w 1988 r. przez Singha oraz współautorów. W zaproponowanej przez Singha metodzie wykorzystano zdolność migracji materiału genetycznego w polu elektrycznym [Singh i in. 1988]. Metoda ta polega na unieruchomieniu w żelu agarozowym komórek, następnie przeprowadzeniu lizy, a potem neutralizacji $\mathrm{w}$ odpowiednim roztworze neutralizującym. Po lizie oraz neutralizacji badane komórki poddaje się elektroforezie, a na koniec wybarwia barwnikami. Wykorzystuje się do tego barwniki wykazujące powinowactwo do DNA, należą do nich: DAPI, azotan srebra, bromek etydyny lub SYBR Green. W zależności od użytego barwnika wybarwione komórki ogląda się pod mikroskopem fluorescencyjnym lub mikroskopem świetlnym. Materiał genetyczny w jądrach komórek w wyniku ekspozycji na substancje toksyczne ulega uszkodzeniu. Powstają wtedy pęknięcia w jednej lub w dwóch niciach DNA, w wyniku czego DNA traci zwartą strukturę oraz staje się podatny na różne modyfikacje chemiczne. W wyniku rozdziału elektroforetycznego materiał genetyczny, który posiada mikropęknięcia ulega przemieszczeniu w kierunku anody. Nieuszkodzone nici pozostają zaś wewnątrz jądra komórki w postaci

\footnotetext{
${ }^{1}$ Uniwersytet Przyrodniczy w Lublinie, Wydział Medycyny Weterynaryjnej, Studenckie Koło Toksykologii Weterynaryjnej

${ }_{2}$ Uniwersytet Przyrodniczy w Lublinie, Wydział Medycyny Weterynaryjnej, Zakład Farmakologii, Toksykologii i Ochrony Środowiska

3 Uniwersytet Przyrodniczy w Lublinie, Wydział Medycyny Weterynaryjnej, Katedra Anatomii i Histologii Zwierząt

${ }^{4}$ marlena.ksiezarczyk@gmail.com

* Badania finansowane ze środków: Biostrateg2/297910/12/NCBR/2016.
} 
związanej z macierzą jądrową. Dlatego ilość materiału genetycznego, która opuszcza komórkę w wyniku elektroforezy, odpowiada mierze ilości uszkodzeń struktury DNA. Materiał genetyczny, który przemieścił się w wyniku elektroforezy, przybiera charakterystyczny kształt ogona komety za zatopioną w agarozie komórką, stąd też wzięła się nazwa tego testu. Komórka zatopiona w agarozie nazywana jest głową komety.

Metoda ta w ostatnich latach uległa wielu modyfikacjom, dzięki czemu wyodrębniono kilka typów testu kometkowego, takich jak: fluorescencyjna hybrydyzacja in situ - test kometkowy, ,alkaliczny” test kometkowy oraz „neutralny” test kometkowy [Hartmann i Speit 1995, Kim i in. 2002, Shaposhnikov i in. 2009, Andem i in. 2013, Czubaszek i in. 2014]. Test kometkowy wykorzystywany jest $\mathrm{w}$ wielu dziedzinach nauki, $\mathrm{np}$. w radiobiologii, toksykologii, ochronie środowiska czy farmakologii [Cotelle i Ferard 1999, Olive 2009]. W ochronie środowiska test ten został wykorzystany w celu biomonitorowania czynników fizycznych oraz chemicznych, które mogą powodować uszkodzenie struktury kwasów nukleinowych fauny i flory [Valverde i Rojas 2009]. Wykorzystanie metody kometkowej w badaniach nad stopniem uszkodzeń struktury DNA umożliwia ocenę wpływu czynników genotoksycznych do których należą pestycydy, metale ciężkie oraz inne związki chemiczne stosowane obecnie w przemyśle oraz rolnictwie [Latchoumycandane i Mathur 2002, Sabine i in. 2015]. Test kometkowy zyskał spore zainteresowanie w badaniach nad oceną stopnia uszkodzenia struktury DNA u różnych gatunków zwierząt spowodowanego narażeniem na metale ciężkie. Jednak w dostępnej literaturze brakuje doniesień na temat wykorzystania tej metody do badań uszkodzeń DNA indukowanych przez metale ciężkie u zwierząt gospodarskich. Dlatego też celem pracy było zbadanie wpływu ekspozycji erytrocytów gęsi na $\mathrm{CdCl}_{2} \mathrm{~W}$ warunkach in vitro na strukturę ich DNA z wykorzystaniem metody kometkowej.

Obserwowany w ostatnich dekadach intensywny rozwój gospodarki przyczynił się do zwiększenia obecności w środowisku metali ciężkich takich jak rtęć, ołów, kadm czy arsen. Metale ciężkie stanowią duże zagrożenie dla zwierząt oraz dla człowieka, ponieważ łatwo ulegają przemieszczeniu w łańcuchu troficznym oraz kumulacji w organizmie, w szczególności w wątrobie i nerkach. Zanieczyszczone kadmem pasze stanowią duże zagrożenie dla ptaków, ponieważ mają wpływ na ich rozmnażanie, przeżywalność piskląt oraz ich rozwój neurobehawioralny. W przypadku drobiu metale ciężkie takie jak kadm i ołów ulegają kumulacji w żołądku, wątrobie, nerkach, mięśniach oraz w kościach [Salwa $i$ in. 2013]. Kadm szeroko wykorzystywany jest w wielu procesach technologicznych, np. do produkcji farb czy baterii niklowo-kadmowych. Pierwiastek ten do organizmu dostaje się głównie drogą pokarmową oraz drogą inhalacyjną. Stanowi duże niebezpieczeństwo dla organizmów żywych, ponieważ może powodować zaburzenia działania układu sercowo-naczyniowego, poprzez zwiększenie przepuszczalności śródbłonka naczyń krwionośnych. Wykazano również, że długotrwałe narażenie na kadm prowadzi do rozwoju niedokrwisto- 
ści ze znaczną retikulocytozą oraz trombocytozą. Długotrwała ekspozycja organizmu na kadm może powodować uszkodzenie układu rozrodczego, polegające na zmianach morfologicznych oraz czynnościowych narządów i komórek rozrodczych [Bonda i in. 2007, Zhang i in. 2008, Kostić i in. 2009, Czeczot i Majewska 2010]. Wykazano również, że kadm może powodować obniżenie aktywności enzymów przeciwutleniających, w wyniku czego zwiększa się ilość wolnych rodników, które przyczyniają się do peroksydacji lipidów. Kadm powoduje negatywne oddziaływanie na komórki układu odpornościowego, w szczególności na limfocyty [Jin-Long i in. 2010]. Pierwiastek ten ma działanie mutagenne powodujące zmiany w strukturze DNA komórek somatycznych. Ma negatywny wpływ na mechanizmy naprawy struktury DNA. Powoduje nieprawidłowy przebieg naprawy DNA polegający na zaburzeniu procesu wycinania zasad, nukleotydów oraz niesparowanych zasad. Ponadto przyczynia się do nieprawidłowych modyfikacji ekspresji genów regulujących syntezę białek odpowiedzialnych za prawidłową proliferację komórek. Udowodniono, że kadm aktywuje receptory śmierci zlokalizowane na błonie komórkowej, przez co indukuje szlak zewnątrzpochodny apoptozy [Bertin i Averbeck 2006].

\section{Badania wlasne}

Krew do badań pobrano od 10 gęsi $(n=10)$ do probówek $z$ EDTA po przecięciu tętnic szyjnych w czasie uboju w zakładach drobiarskich, schłodzono i transportowano do laboratorium w temperaturze $4^{\circ} \mathrm{C}$. Do dalszych badań pełną krew odwirowano (500 obrotów/min) a następnie pobrano po $40 \mu$ frakcji erytrocytów do probówek Eppendorf, które 5-krotnie płukano i odwirowywano (500 obrotów/min) w roztworze PBS (Aslab, nr kat.120/100 PBSC) o $\mathrm{pH}=7,4$. Materiał badawczy podzielono na dwie grupy: grupę pierwszą $(n=5)$ kontrolną oraz grupę drugą $(\mathrm{n}=5)$ badawczą i przechowywano go w temperaturze $4^{\circ} \mathrm{C}$ do dalszych analiz. Do testu kometkowego pobrano po $20 \mu \mathrm{l}$ frakcji krwinek czerwonych i umieszczono je w $40 \mu \mathrm{PBS}$. Grupę pięrwszą stanowiły erytrocyty inkubowane bez $\mathrm{CdCl}_{2}$, grupa drugą zaś - erytrocyty inkubowane przez 30 min z $20 \mu \mathrm{CdCl}_{2}$ o stężeniu $25 \mu \mathrm{M}$. Po inkubacji w warunkach kontrolnych i doświadczalnych pobrano po $20 \mu \mathrm{l}$ frakcji. Następnie zmieszano je z 1,0\% ciekłą agarozą o niskiej temperaturze topnienia (Sigma-Aldrich, nr kat. A9414-25G) i umieszczono na wcześniej przygotowanych szkiełkach mikroskopowych pokrytych $0,8 \%$ agarozą o normalnym punkcie topnienia (Sigma-Aldrich, nr kat. A4718-100G). Tak przygotowane szkiełka zanurzono w roztworze lizującym (2,5 M NaCl, $100 \mathrm{mM}$ EDTA, 10 mMTris, $1 \%$ Triton $\mathrm{X}-100)$ o $\mathrm{pH}=10 \mathrm{na} 2 \mathrm{~h}$ w temperaturze $4^{\circ} \mathrm{C}$, aby poddać lizie erytrocyty. Następnie szkiełka umieszczono na $30 \mathrm{~min}$ w komorze wypełnionej roztworem do elektrolizy ( $300 \mathrm{mM} \mathrm{NaOH}$; $1 \mathrm{mM}$ EDTA) schłodzonym do temperatury $4^{\circ} \mathrm{C}$. Po tym okresie przeprowadzono elektroforezę $(300 \mathrm{~mA} ; 0.8 \mathrm{~V} / \mathrm{cm})$ w temperaturze $4^{\circ} \mathrm{C}$, trwającą $30 \mathrm{~min} . \mathrm{W}$ dalszej kolejności zneutralizowano 
próbki w roztworze neutralizującym $(0,4 \mathrm{M}$ Tris- $\mathrm{HCl})$ o $\mathrm{pH}=7,5$. Próbki DNA wizualizowano za pomocą barwnika fluorescencyjnego $1 \mu \mathrm{M}$ DAPI (Thermo Fisher Scientific, kat. D3571). Po nałożeniu szkiełka nakrywkowego, szkiełka oglądano pod mikroskopem epifluorescencyjnym (BX-DSU Olympus) wyposażonego w filtr interferencyjny dla użytego barwnika DAPI (wzbudzenie/emisja; 358/461 nm). Zdjęcia wykonano za pomocą kamery (DP-70 Olympus). Zawartość DNA w kometach analizowano za pomocą darmowego programu CASP (www.casplab.com). Na podstawie analizy natężenia fluorescencji obliczono procentową zawartość DNA w kometach. Analizie poddano 50 komet po 5 od każdego osobnika z obu grup (kontrolnej oraz eksperymentalnej).

Analiza obrazu za pomocą programu komputerowego CASP wykazała, że zawartość procentowa DNA w kometach wynosiła 0,804 $\pm 0,569$ w grupie kontrolnej oraz 1,387 $\pm 1,075 \mathrm{w}$ grupie inkubowanej z kadmem. Przeprowadzone badania wskazały negatywny wpływ $\mathrm{CdCl}_{2}$ na erytrocyty gęsi oraz potwierdziły przydatność metody kometkowej do analizy uszkodzeń struktury DNA komórek in vitro. Test kometkowy jako czuła metoda służąca do badania uszkodzeń struktury DNA został również wykorzystany w badaniach nad genotoksycznością kadmu prowadzonych przez Kasuba i in [2002]. W zaproponowanym przez niego doświadczeniu badano wpływ kadmu na limfocyty szczurów rasy wistar. Szczury zostały podzielone na 5 grup, jedną kontrolną (bez kadmu) i cztery grupy badawcze. Szczury z dwóch grup badawczych traktowano roztworem kadmu podawanym doustnie (dzienna dawka $0,5 \mathrm{mg} \mathrm{Cd} / \mathrm{kg}^{-1} \mathrm{~m}$.c.) przez 9 dni. Pozostałym dwóm grupom badawczym w piątym dniu po urodzeniu wstrzykiwano podskórnie $\mathrm{kadm}\left(0,5 \mathrm{mg} \mathrm{Cd} / \mathrm{kg}^{-1}\right.$ m.c.). W wyniku analizy z wykorzystaniem metody kometkowej wykazano wzrost długości komet $u$ grup badawczych narażonych na kadm w porównaniu z grupą kontrolną, niezależnie od drogi podania kadmu [Kasuba $i$ in. 2002]. Innymi badaniami potwierdzającymi przydatność stosowania metody kometkowej do oceny genotoksyczności indukowanej $\mathrm{CdCl}_{2}$ były badania przeprowadzone przez Jindal i Verma [2015]. Badano wpływ $\mathrm{CdCl}_{2}$ o stężeniu 0,37 oraz $0,62 \mathrm{mg} / \mathrm{L}$ wody na ryby słodkowodne Rohu (Labeorohita) przez 100 dni. Do przeprowadzenia testu kometkowego wykorzystano erytrocyty pobierane od ryb w dniach 1, 3, 5, 10, 15, 30, 60 i 100 trwania doświadczenia. Wykonane analizy wykazały znaczy wzrost zawartości procentowej DNA w kometach erytrocytów ryb narażonych na oba stężenia $\mathrm{CdCl}_{2}$ [Jindal i Verma 2015]. W badaniach przeprowadzonych przez Kousar i Javed [2014] potwierdzono przydatność testu kometkowego do określenia genotoksycznego działania cyn$\mathrm{ku}$, miedzi oraz arsenu na erytrocyty krwi obwodowej $\mathrm{u}$ ryb słodkowodnych. $\mathrm{W}$ ich badaniach dodatkowo zaprezentowano wykorzystanie testu kometkowego do biomonitoringu zanieczyszczeń osadów dennych rzek i jezior [Kousar i Javed 2014]. 


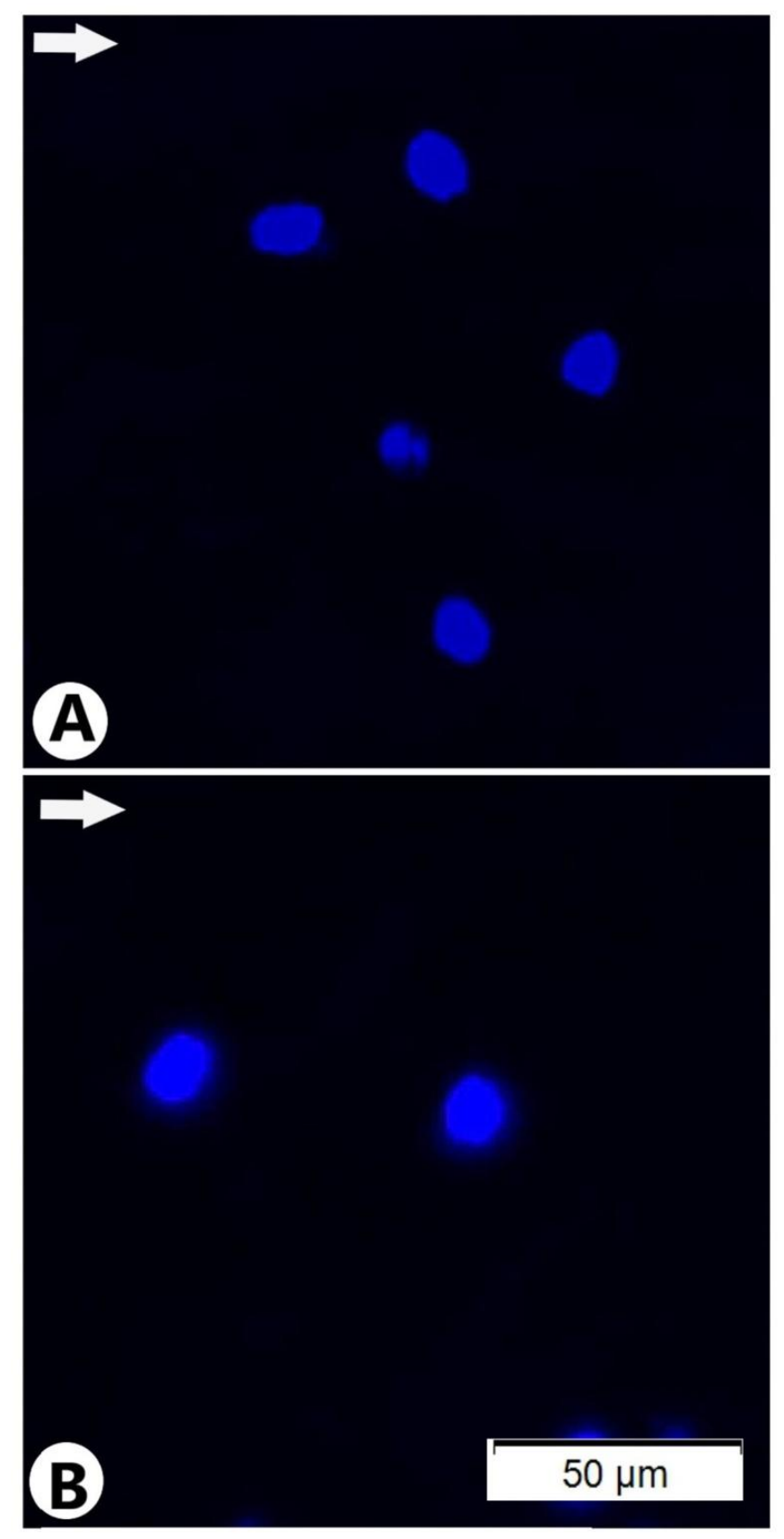

Fot. 1. Erytrocyty gęsi wybarwione barwnikiem DAPI po przeprowadzeniu testu kometkowego. $\mathrm{A}$ - erytrocyty gęsi grupy kontrolnej inkubowane bez $\mathrm{CdCl}_{2}, \mathrm{~B}$ - erytrocyty gęsi inkubowane $\mathrm{z}$ roztworem $\mathrm{CdCl}_{2}$ (białe strzałki oznaczają kierunek migracji materiału genetycznego erytrocytów w kierunku anody podczas elektroforezy)

(fot. M. Księżarczyk, P. Leśniak, M.M.B. Arciszewski, J.L. Valverde Piedra) 


\section{Podsumowanie}

Metodą analizy stopnia uszkodzenia materiału genetycznego jest elektroforeza żelowa pojedynczych komórek nazywana obecnie testem kometkowym. Główną zaletą tego testu jest możliwość wykrywania nawet najmniejszych modyfikacji materiału genetycznego. Dzięki zastosowaniu testu kometkowego możemy określić wpływ różnych czynników genotoksycznych na materiał genetyczny. W obliczu obecnych problemów związanych z zanieczyszczeniem terenów uprawnych i możliwością przedostania się metali ciężkich do roślin, z których wytwarzane są pasze, a kolejno wraz z nimi możliwością przedostania się metali ciężkich do organizmu zwierząt. Test kometkowy jako czuła metoda doskonale sprawdza się do określenia stopnia uszkodzenia struktury DNA spowodowanej ekspozycją na kadm oraz inne metale ciężkie u różnych gatunków zwierząt. Technika ta obecnie zdobywa coraz większą popularność ze względu na jej niskie koszty oraz krótki czas otrzymania wyników [Tice i in. 2000, Kasuba i in. 2002, Kousar i Javed 2014].

\section{Bibliografia}

Andem A.B., Agbor R.B., Ekpo I.A., 2013. Review on comet assay: a reliable tool for assessing dna damage in animal models. J. Curr. Res. Sci. 1(6), 405-427.

Bertin G., Averbeck D., 2006. Cadmium: cellular effects, modifications of biomolecules, modulation of DNA repair and genotoxic consequences (a review). Biochimie 88(11), 1549-1559.

Bonda E., Włostowski T., Krasowska A., 2007. Metabolizm i toksyczność kadmu u człowieka i zwierząt. Kosmos 56(1-2), 87-97.

Cotelle S., Ferard J.F., 1999. Comet assay in genetic ecotoxicology: A review. Environ. Mol. Mutagen. 34(4), 246-255.

Czeczot H., Majewska M., 2010. Kadm - zagrożenie i skutki zdrowotne. Farm. Pol. 66(4), 243-250.

Czubaszek M., Szostek M., Wójcik E., Andraszek K., 2014. Test kometowy jako metoda identyfikacji niestabilności chromosomów. Post. Hig. 68, 695-700.

Hartmann A., Speit G., 1995. Genotoxic effects of chemicals in the single cell gel (SCG) test with human blood cells in relation to the induction of sister-chromatid exchanges (SCE). Mut. Res $346,49-56$.

Jindal R., Verma S., 2015. In vivo genotoxicity and cytotoxicity assessment of cadmium chloride in peripheral erythrocytes of Labeo rohita (Hamilton). Ecotoxicol. Environ. Safety 118, 1-10.

Jin-Long L., Hui-Xin L., Shu L., Zhao-Xin T., Shi-Wen Xu., Xiao-Long W., 2010. Oxidative Stress-Mediated Cytotoxicity of Cadmium in Chicken Splenic Lymphocytes. Pol. J. Environ. Stud. 19(5), 947-956

Kasuba V., Rozgaj R., Sari M.M., Blanusa M., 2002. Evaluation of genotoxic damage of cadmium chloride in peripheral blood of suckling Wistar rats. J. Appl. Toxicol. 22(4), 271-277.

Kim B., Park J.J., Edlaer L., Fournier D., Haase W., Sautter-Bihl M., Gotzes F., Thielmann H.W., 2002. New measurement of DNA repairs in the single-cell gel electrophoresis (comet) assay. Environ. Mol. Mutagen. 40, 50-56.

Kostić M.M., Ognjanović B., Dimitrijević S., Zikić R.V., Zsctajn A., Rosić G.L., Zivković R.V., 2009. Cadmium-induced changes of antioxidant and metabolic status in red blood cells of rats: in vivo effects. Eur. J. Haematol. 51(2), 86-92.

Kousar S., Javed M. (red.), 2014. Diagnosis of metals induced DNA damage in fish using comet assay. Pak. Vet. J. 35(2), 168-172. 
Latchoumycandane C., Mathur P.P., 2002. Induction of oxidative stress in the rat testis after short-term exposure to the organochlorine pesticide methoxychlor. Arch. Toxicol. 76, 692-698.

Olive P.L., 2009. DNA damage and repair in individual cells: applications of the comet assay in radiobiology. Int. J. Radiat. Biol. 75(4), 395-405.

Peggy L.O., Banath J.P., 2006. The comet assay: a method to measure DNA damage in individual cells. Nat. Protoc. 1(1), 23-29.

Pellegri V., Gorbi G., Buschini A., 2019. DNA damage detection by comet assay on Daphnia magna: Application in freshwater biomonitoring. Sci. Total. Environ. 705, 135780.

Sabine A.S.L., Amaya A., Collins A.R., 2015. The comet assay: past, present, and future. Front. Genet. 6, 266.

Salwa A., Abduljaleel M., Shuhaimi O., 2013. Toxicity of cadmium and lead in Gallus gallus domesticus assessment of body weight and metal content in tissues after metal dietary supplements. Pak. J. Biol. Sci. 16, 1551-1556.

Shaposhnikov S., Frengen E., Collins A.R., 2009. Increasing the resolution of the comet assay using fluorescent in situ hybridization - a review. Mutagenesis 24(5), 383-389.

Singh N.P., McCoy M.T., Tice R.R., Schneider E.L., 1988. A simple technique for quantitation of low levels of DNA damage in individual cells. Exp. Cell Res. 175, 184-191.

Tice R.R., Agurell E., Anderson D., Burlinson B., Hartmann A., Kobayashi H., Miyamae Y., Rojas E., Ryu J.C., Sasaki Y.E. (red.), 2000. Single cell gel/comet assay: Guidelines for in vitro and in vivo genetic toxicology testing. Environ. Mol. Mutagen. 35, $206-221$.

Valverde M., Rojas E., 2009. Environmental and occupational biomonitoring using the Comet assay. Mutat. Res., Fundam. Mol. Mech. Mutagen 681(1), 93-109.

Zhang Y., Wang Y., Yu R., Zhang S., Wu Z., 2008. Effects of heavy metals Cd2+, Pb2+ and Zn2+ on DNA damage of loach Misgurnus anguillicaudatus. Front. Biol. China 3(1), 50-54. 
Paulina Lipińska ${ }^{1,3}$, Małgorzata Goleman ${ }^{2}$

\section{Pożądane cechy u owczarków belgijskich w zależności od linii hodowlanej}

Desirable traits in Belgian shepherd depending of the breeding line

Owczarek belgijski jest to jedna rasa o czterech odmianach, różniących się długością, strukturą, wyglądem i kolorem sierści. Wyróżnia się dwie odmiany długowłose: Groenendael i Tervuren, odmianę szorstkowłosą Laekenois i odmianę krótkowłosą Malinois [Wzorzec FCI nr 15 owczarek belgijski]. Według wzorca rasy Międzynarodowej Federacji Kynologicznej (FCI) owczarek belgijski jest charakteryzowany jako: „Pierwotnie pies pasterski, obecnie wszechstronnie użytkowy pies pracujący (obrończy, stróżujący, tropiący), jak również doskonały pies rodzinny" [Wzorzec FCI nr 15 owczarek belgijski].

Hodowcy psów stawiają sobie różne cele hodowlane [Boruta i in. 2018]. Selekcja w kierunku różnych cech doprowadziła do wyodrębnienia tzw. eksterierowych i użytkowych linii hodowlanych. Linia eksterierowa, inaczej zwana wystawową, skupia się na hodowli psów z wyglądem jak najbardziej zgodnym ze wzorcem [Boruta i in. 2018], jednak przypisuje się w niej mniejszą wartość cechom charakteru. W linii użytkowej eksterier psa ma mniejsze znaczenie, natomiast osobniki w tej linii wyróżniają się doskonałymi cechami charakteru [Goleman 2011]. Różnice pomiędzy liniami hodowlanymi nie są jednak tak znaczne jak w przypadku owczarków niemieckich.

W przeszłości psy pasterskie pomagały przy manewrowaniu stadami zwierząt gospodarskich. Obecnie są one często używane jako psy obronne i psy pracujące w służbach [Correau i Langlois 2004, Lipka i in. 2017]. Spadek ilości drapieżników i hodowli owiec w północno-zachodniej Europie sprawił, że duże psy pasterskie zaczęto wykorzystywać jako psy obronne [Courreau i Langlois 2005]. Z uwagi na użytkowość psów rozpoczęto selekcję w tym kierunku. Poprzez kojarzenie osobników, które charakteryzują się największą chęcią do pracy oraz posiadają najlepsze cechy użytkowe i zdrowotne, pozyskuje się psy przydatne do pracy [Goleman 2011].

\footnotetext{
${ }^{1}$ Uniwersytet Przyrodniczy w Lublinie, Wydział Nauk o Zwierzętach i Biogospodarki, Studenckie Koło Naukowe Nauk o Zwierzętach i Biogospodarki - Sekcja Kynologiczna

${ }^{2}$ Uniwersytet Przyrodniczy w Lublinie, Wydział Nauk o Zwierzętach i Biogospodarki, Katedra Etologii Zwierząt i Łowiectwa

${ }^{3}$ paulina.lipinska100@wp.pl
} 
W XX w. nastąpiła selekcja owczarka belgijskiego pod względem jego cech obronnych, w szczególności zdolności kontrolowanego gryzienia, która została szczególnie rozwinięta [Courreau i Langlois 2005]. Wysoki poziom temperamentu i wytrwałość doprowadziła do wzrostu popularności owczarków belgijskich Malinois w sportach obronnych [Gardianova i in. 2013]. Są to psy wymagające dużej ilości kontaktu $\mathrm{z}$ opiekunem i zainteresowania $\mathrm{z}$ jego strony oraz bezwzględnie potrzebują ciągłego treningu i szkolenia [Bąk 2017]. Linia użytkowa $\mathrm{w}$ dużej mierze przeważa u odmiany Malinois. W zależności od linii hodowlanej różnice $\mathrm{w}$ eksterierze są u tej odmiany widoczne. U pozostałych odmian dominują linie eksterierowe, natomiast nie ma dużego zróżnicowania w wyglądzie pomiędzy poszczególnymi liniami. Pomimo hodowli owczarków belgijskich w kierunku eksterieru, w której cechom charakteru przypisuje się mniejsze znaczenie, zgodnie z wymogami Związku Kynologicznego w Polsce, psy tej rasy muszą zdać testy psychiczne. Jest to dodatkowy wymóg według Regulaminu Hodowli Psów Rasowych do uzyskania uprawnień hodowlanych. Zgodnie z Regulaminem testów psychicznych [Regulamin testów psychicznych] sprawdza się: odporność na strzał, znajomość rękawa, ostrość (predyspozycje obrony, wykształcenie popędów), twardość (pewność siebie, odporność psychiczna) oraz usposobienie. W teście pies może maksymalnie uzyskać 15 punktów. Psy, które przed przystąpieniem do testu były wyszkolone lub przygotowane do obrony, muszą zdobyć większą ilość punktów, aby zaliczyć test (11 punktów). Pies, który nie był szkolony, musi uzyskać minimalnie 8 punktów.

Materiał badawczy stanowiły wyniki anonimowego badania ankietowego skierowanego do osób decydujących się na zakup/posiadanie owczarka belgijskiego. W ankiecie respondentom zadano ogólne pytania dotyczące ich charakterystyki, doświadczenia w pracy z psami, tego, którą linię i odmianę preferują oraz jakich cech pożądają u psa. Zapytano czy ankietowani zamierzają uprawiać sporty z psem, a jeśli tak, to jakie? Zadano również pytania o to, czy według respondentów, cechy takie jak: zgodność wyglądu psa ze wzorcem, nastawienie na pracę z człowiekiem, silna psychika, wyszkolenie przodków psa i socjalizacja u owczarków belgijskich są bardzo istotne, mało istotne lub w ogóle nie są istotne. Wyniki badań analizowano, wyliczając frekwencję poszczególnych odpowiedzi, z uwzględnieniem podziału na linie hodowlane.

W badaniu wzięło udział 83 respondentów, w tym 64 kobiety i 19 mężczyzn. W grupie badanych osób największą grupę stanowiły osoby w wieku 30-45 lat (53\%), kolejno 18-30 lat (35\%) i osoby powyżej 45 lat (12\%). Jeśli chodzi o wykształcenie 59 ankietowanych miało wykształcenie wyższe, 21 - średnie, 2 -zasadnicze zawodowe i 1 osoba wykształcenie podstawowe.

Spośród ankietowanych 78 osób miało wiedzę, jakie są różnice pomiędzy liniami hodowlanymi u owczarków belgijskich. Cechami, które według nich odróżniają te linie są: popędy (33\%), eksterier (30\%), psychika (26\%), temperament $(8 \%)$ i pochodzenie psa $(3 \%)$. 


\section{Preferowana odmiana i linia hodowlana}

Analiza uzyskanych wyników wykazała, że 64\% respondentów preferowało linie użytkową, $14 \%$ eksterierową, a dla $22 \%$ nie miało to znaczenia. Respondenci najchętniej wybierali odmianę Malinois (78\%), następnie Tervueren (11\%), Groenendael $(10 \%)$ i tylko $1 \%$ Lakenois. Wybór odmiany Malinois przeważał we wszystkich preferencjach dotyczących linii hodowlanych, najbardziej w przypadku

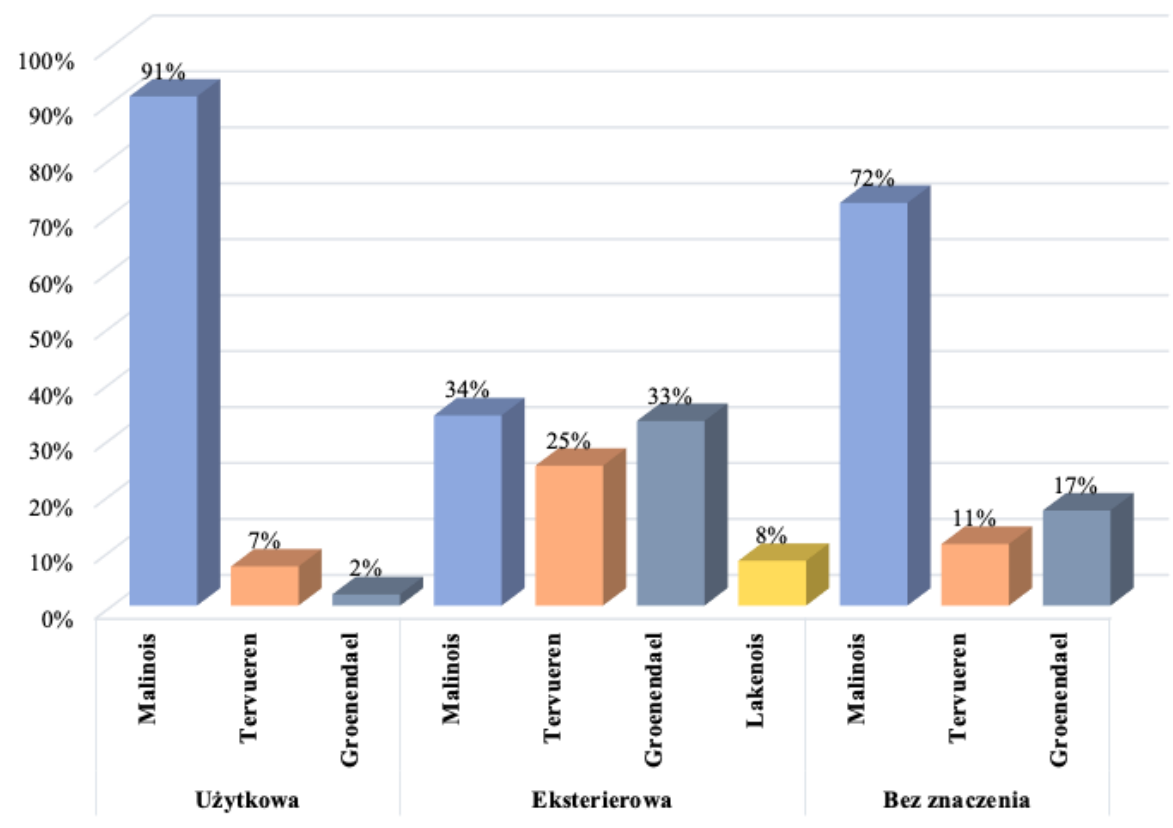

Rys. 1. Procentowy udział poszczególnych odmian owczarków belgijskich w zależności od preferowanej przez ankietowanych linii hodowlanej

linii użytkowej. Correau i Lanlois [2005] wykazali przewagę odmiany Malionis w porównaniu do reszty odmian owczarków belgijskich ze względu na większą zdolność fizyczną i większą chęć do pracy. W liniach użytkowych odmiany Malinois preferowane są psy o mocniejszej budowie, natomiast linia eksterierowa u tej odmiany charakteryzuje się sierścią o większej obfitości. Różnica ta pomiędzy liniami hodowlanymi u innych odmian nie jest widoczna.

\section{Doświadczenie przewodnika}

Według Svartberga [2002] jednym z najważniejszych czynników osiągnięcia sukcesu jest doświadczenie przewodnika. Owczarki belgijskie mogą uzyskiwać wyższe wyniki w szkoleniu, jeżeli są prowadzone przez bardziej doświadczone- 
go przewodnika [Lipka i in. 2017]. Wśród ankietowanych 69 osób (83\%) posiadało doświadczenie w pracy z owczarkami belgijskimi. Analiza doświadczenia uwzględniająca podział na linie hodowlane wykazała, że we wszystkich przypadkach $83 \%$ respondentów posiadało doświadczenie, $17 \%$ zaś nie posiadało doświadczenia.

Sport z psami uprawiało $75 \%$ ankietowanych, największe doświadczenie miały osoby preferujące linię użytkową. Respondenci wymienili takie sporty jak: sporty obrończe, posłuszeństwo sportowe, agility, tropienie, dogfrisbee, posłuszeństwo podstawowe, pasienie, nosework, dogtrekking/canicross, IRO (egzaminy psów ratowniczych).

Rasy psów, z którymi respondenci mieli doświadczenie w treningu, zostały podzielone na grupy według klasyfikacji Międzynarodowej Federacji Kynologicznej - FCI. Na pierwszym miejscu znalazły się owczarki belgijskie, kolejno owczarki niemieckie, inne rasy z grupy pierwszej i mieszańce. Respondenci wymienili również po kilka osobników z grup drugiej, trzeciej, piątej, ósmej, dziewiątej.

\section{Uprawianie sportu z psem}

84\% ankietowanych wykazało chęć uprawiania sportu z owczarkiem belgijskim. Analiza $z$ podziałem na linie hodowlane wykazała, że najwięcej respondentów zamierzało uprawiać sport z tych, którzy preferowali psa z linii użytkowej, najmniej - z tych, dla których linia hodowlana nie miała znaczenia. $Z$ wymienionych sportów największą popularnością cieszyły się sporty obrończe, kolejno posłuszeństwo sportowe, agility, tropienie, dogfrisbee, pasienie, nosework, IRO, posłuszeństwo podstawowe i dogtrekking/canicross. W przypadku linii użytkowej najwięcej respondentów zadeklarowało chęć uprawiania z psem sportów obrończych (33\%), dla linii eksterierowej było to pasienie (29\%). Ankietowani, dla których linia nie miała znaczenia, najczęściej wybierali posłuszeństwo sportowe i tropienie (po 23\%).

\section{Pożądane cechy u owczarków belgijskich}

Predyspozycje psychiczne są bardzo ważne przy wyborze psa [Bąk 2017]. Są one sprawdzane za pomocą różnych testów. Testy określające cechy danego zwierzęcia opierają się na subiektywnej ocenie doświadczonego testera, który obserwuje reakcje psa nie tylko w sytuacji testowej, ale również przed nią i bezpośrednio po niej [Walczak $\mathrm{i}$ in. 2016]. Ocena psa powinna być obiektywna [Jones i Gosling 2005]. Należy pamiętać, że otoczenie jest ważnym elementem stabilnej psychiki [Karpiński i in. 2012]. 


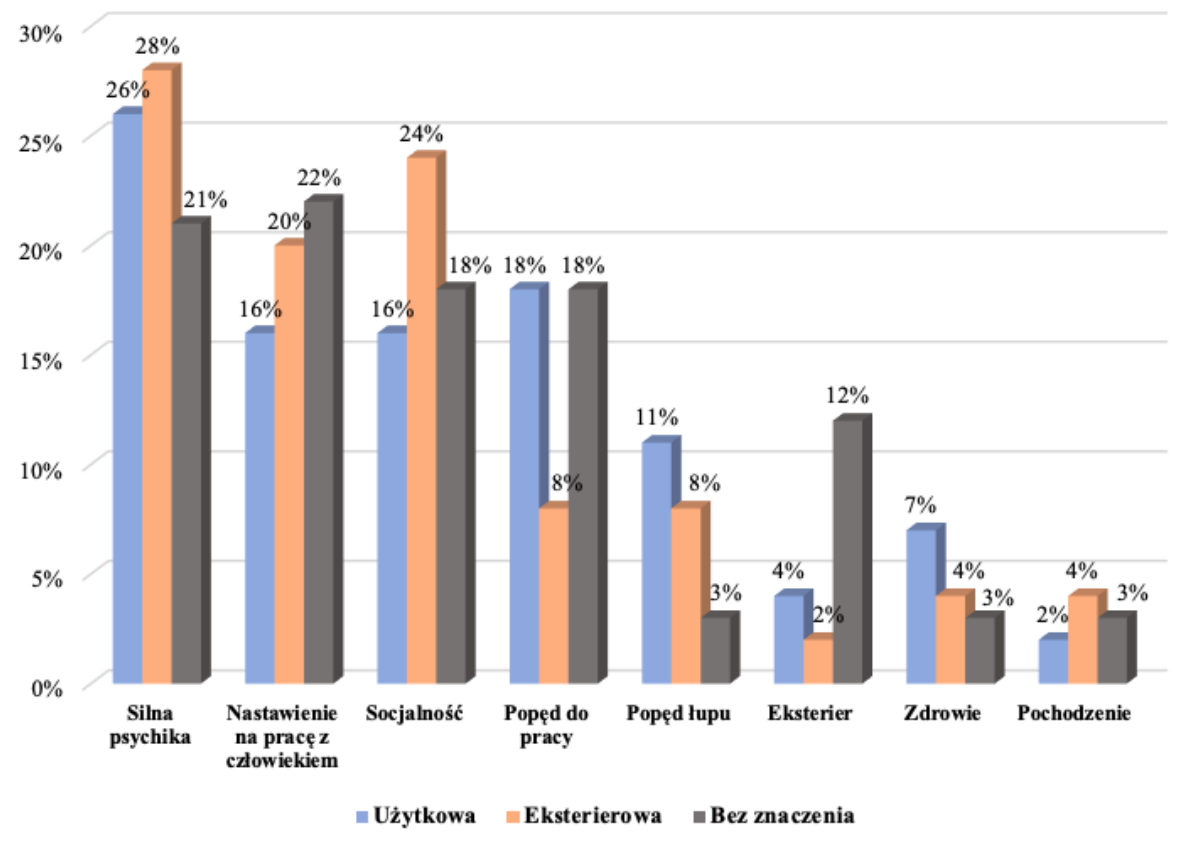

Rys. 2. Pożądane cechy u owczarków belgijskich w zależności od linii hodowlanej

Wśród wymienionych przez respondentów cech, których oczekują u psa, na pierwszym miejscu pojawiła się silna psychika (26\%), kolejno nastawienie psa na pracę $\mathrm{z}$ człowiekiem $(18 \%)$, socjalność $(17 \%)$, popęd do pracy $(17 \%)$, popęd łupu $(9 \%)$, eksterier i zdrowie (po $5 \%$ ) oraz pochodzenie psa $(3 \%)$. W analizie pożądanych cech $\mathrm{w}$ zależności od linii hodowlanej silna psychika przeważała w liniach użytkowej i eksterierowej, nastawienie psa na pracę z człowiekiem było na pierwszym miejscu tam, gdzie linia hodowlana nie miała znaczenia.

\section{Znaczenie wybranych cech u owczarków belgijskich}

Zgodność wyglądu psa ze wzorcem. Według ankietowanych wygląd psa najbardziej zbliżony wzorcowi rasowemu jest w $48 \%$ mało istotny, w $47 \%$ bardzo istotny i dla 5\% ankietowanych w ogóle nie jest istotny. Wygląd największe znaczenie miał dla respondentów, dla których linia hodowlana nie miała znaczenia, najmniejsze znaczenie miał w przypadku osób preferujących linie użytkową.

Nastawienie psa na pracę z człowiekiem. Według Lipki i in. [2017] można przypuszczać, że statystycznie istotnie lepsze wyniki w szkoleniu owczarków belgijskich w porównaniu $\mathrm{z}$ owczarkami niemieckimi są determinowane poprzez gotowość i chęć do pracy z człowiekiem tych pierwszych. Spośród ankietowanych 82 osoby uważały, że nastawienie psa na pracę z człowiekiem jest bardzo 
istotne. Tylko jedna osoba, dla której linia hodowlana była bez znaczenia, uważała, że jest to cecha mało istotna.

Wyszkolenie przodków psa. Wyszkolenie przodków psa dla $60 \%$ respondentów było bardzo istotne, dla $36 \%$ - mało istotne i według $4 \%$ - nie było to w ogóle istotne. $\mathrm{W}$ analizie tej cechy z podziałem na linie hodowlane było to najbardziej istotne $\mathrm{u}$ ankietowanych preferujących linię użytkową, najmniej u tych, dla których linia nie miała znaczenia.

W celu utrwalenia i zachowania właściwych cech użytkowych prowadzone są szkolenia, w wyniku których pies może uzyskać certyfikat użytkowości [Grondkowska i Kuźnicka 2011]. Zgodnie z nomenklaturą FCI owczarek belgijski jest rasą podlegającą próbom pracy. Zaliczenie ich jest niezbędne, aby pies mógł uzyskać tytuł Międzynarodowego Championa. Nie powinno się jednak spodziewać, że szczenięta psów z linii użytkowych charakteryzują się zawsze wybitną użytkowością [Boruta $i$ in. 2018].

Silna psychika. Według większości respondentów (93\%) silna psychika u psa jest bardzo istotna, dla 7\% jest ona mało istotna. Przy uwzględnieniu podziału na linie hodowlane najbardziej (w 100\%) jest ona znacząca w przypadku linii eksterierowej, kolejno użytkowej (96\%) i najmniej, gdy linia hodowlana nie ma znaczenia $(78 \%)$.

Socjalizacja. Dobrze przeprowadzona socjalizacja kształtuje pożądane zachowanie i reakcje psów w kontakcie z człowiekiem [Kamieniak i in. 2015]. Socjalizacja u owczarków belgijskich dla $95 \%$ ankietowanych była bardzo istotna, dla $4 \%$ - mało istotna i dla $1 \%$ - w ogóle nie miała znaczenia. Respondenci w $100 \%$ uznali ją za bardzo istotną w przypadku tych preferujących linię eksterierową i tych, dla których linia nie miała znaczenia. Dla ankietowanych preferujących linię użytkową socjalizacja w $92 \%$ była bardzo istotna, w 6\% - mało istotna i dla $2 \%$ - w ogóle nie była istotna.

Tabela 1. Znaczenie wybranych cech u owczarków belgijskich dla ankietowanych w zależności od preferowaną przez nich linię hodowlaną

\begin{tabular}{|l|c|c|c|c|c|c|c|c|c|c|}
\hline \multirow{2}{*}{ Cecha } & \multicolumn{9}{|c|}{ Preferowana linia hodowlana } \\
\cline { 2 - 10 } & \multicolumn{2}{|c|}{ użytkowa $(\mathrm{n}=53)$} & \multicolumn{2}{|c|}{ eksterierowa $(\mathrm{n}=12)$} & \multicolumn{2}{c|}{ bez znaczenia $(\mathrm{n}=18)$} \\
\cline { 2 - 10 } & $\begin{array}{c}\text { bardzo } \\
\text { istotna }\end{array}$ & $\begin{array}{c}\text { mało } \\
\text { istotna }\end{array}$ & $\begin{array}{l}\text { całkowici } \\
\text { nieistotna }\end{array}$ & $\begin{array}{c}\text { bardzo } \\
\text { istotna }\end{array}$ & $\begin{array}{c}\text { mało } \\
\text { istotna }\end{array}$ & $\begin{array}{c}\text { calkowicie } \\
\text { nieistotna }\end{array}$ & $\begin{array}{l}\text { bardzo } \\
\text { istotna }\end{array}$ & $\begin{array}{l}\text { mało } \\
\text { istotna }\end{array}$ & $\begin{array}{c}\text { całkowicie } \\
\text { nieistotna }\end{array}$ \\
\hline $\begin{array}{l}\text { Zgodność } \\
\text { wyglądu } \\
\text { ze wzorcem }\end{array}$ & $\begin{array}{c}32 \% \\
(\mathrm{n}=17)\end{array}$ & $\begin{array}{c}62 \% \\
(\mathrm{n}=3)\end{array}$ & $\begin{array}{c}6 \% \\
(\mathrm{n}=3)\end{array}$ & $\begin{array}{c}67 \% \\
(\mathrm{n}=8)\end{array}$ & $\begin{array}{c}33 \% \\
(\mathrm{n}=4)\end{array}$ & $\begin{array}{c}0 \% \\
(\mathrm{n}=0)\end{array}$ & $\begin{array}{c}78 \% \\
(\mathrm{n}=14)\end{array}$ & $\begin{array}{c}17 \% \\
(\mathrm{n}=3)\end{array}$ & $\begin{array}{c}5 \% \\
(\mathrm{n}=1)\end{array}$ \\
\hline $\begin{array}{l}\text { Nastawienie } \\
\text { na pracę } \\
\text { z człowiekiem }\end{array}$ & $\begin{array}{c}100 \% \\
(\mathrm{n}=53)\end{array}$ & $\begin{array}{c}0 \% \\
(\mathrm{n}=0)\end{array}$ & $\begin{array}{c}0 \% \\
(\mathrm{n}=0)\end{array}$ & $\begin{array}{c}100 \% \\
(\mathrm{n}=12)\end{array}$ & $\begin{array}{c}0 \% \\
(\mathrm{n}=0)\end{array}$ & $\begin{array}{c}0 \% \\
(\mathrm{n}=0)\end{array}$ & $\begin{array}{c}94 \% \\
(\mathrm{n}=17)\end{array}$ & $\begin{array}{c}6 \% \\
(\mathrm{n}=1)\end{array}$ & $\begin{array}{c}0 \% \\
(\mathrm{n}=0)\end{array}$ \\
\hline $\begin{array}{l}\text { Wyszkolenie } \\
\text { przodków psa }\end{array}$ & $\begin{array}{c}82 \% \\
(\mathrm{n}=73)\end{array}$ & $\begin{array}{c}18 \% \\
(\mathrm{n}=16)\end{array}$ & $\begin{array}{c}0 \% \\
(\mathrm{n}=0)\end{array}$ & $\begin{array}{c}67 \% \\
(\mathrm{n}=8)\end{array}$ & $\begin{array}{c}25 \% \\
(\mathrm{n}=3)\end{array}$ & $\begin{array}{c}8 \% \\
(\mathrm{n}=1)\end{array}$ & $\begin{array}{c}28 \% \\
(\mathrm{n}=5)\end{array}$ & $\begin{array}{c}61 \% \\
(\mathrm{n}=11)\end{array}$ & $\begin{array}{c}11 \% \\
(\mathrm{n}=2)\end{array}$ \\
\hline $\begin{array}{l}\text { Silna } \\
\text { psychika }\end{array}$ & $\begin{array}{c}96 \% \\
(\mathrm{n}=51)\end{array}$ & $\begin{array}{c}4 \% \\
(\mathrm{n}=2)\end{array}$ & $\begin{array}{c}0 \% \\
(\mathrm{n}=0)\end{array}$ & $\begin{array}{c}100 \% \\
(\mathrm{n}=12)\end{array}$ & $\begin{array}{c}0 \% \\
(\mathrm{n}=0)\end{array}$ & $\begin{array}{c}0 \% \\
(\mathrm{n}=0)\end{array}$ & $\begin{array}{c}78 \% \\
(\mathrm{n}=14)\end{array}$ & $\begin{array}{c}22 \% \\
(\mathrm{n}=4)\end{array}$ & $\begin{array}{c}0 \% \\
(\mathrm{n}=0)\end{array}$ \\
\hline Socjalizacja & $\begin{array}{c}92 \% \\
(\mathrm{n}=49)\end{array}$ & $\begin{array}{c}6 \% \\
(\mathrm{n}=3)\end{array}$ & $\begin{array}{c}2 \% \\
(\mathrm{n}=1)\end{array}$ & $\begin{array}{c}100 \% \\
(\mathrm{n}=12)\end{array}$ & $\begin{array}{c}0 \% \\
(\mathrm{n}=0)\end{array}$ & $\begin{array}{c}0 \% \\
(\mathrm{n}=0)\end{array}$ & $\begin{array}{c}100 \% \\
(\mathrm{n}=18)\end{array}$ & $\begin{array}{c}0 \% \\
(\mathrm{n}=0)\end{array}$ & $\begin{array}{c}0 \% \\
(\mathrm{n}=0)\end{array}$ \\
\hline
\end{tabular}


Na wizerunek dobrego psa składają się różne cechy, umiejętności oraz szkolenie [Grondkowska i Kuźnicka 2011]. W zależności od preferowanej przez respondentów linii hodowlanej stwierdzono różnice w doświadczeniu przewodnika, postrzeganiu istotności wyglądu psa zgodnie ze wzorcem, ważności wyszkolenia przodków psa oraz posiadaniu przez psa silnej psychiki. Właściciele psów oraz osoby pracujące $\mathrm{z}$ psami zdają sobie sprawę, że równowaga psychiczna i temperament są ważne [Jones i Gosling 2005]. Dostrzeżono, że w liniach użytkowych i eksterierowych u owczarków belgijskich najbardziej pożądaną cechą jest silna psychika.

\section{Bibliografia}

Bąk M., 2017. Cechy psa-kandydata do służby w policji w kategorii pies patrolowo-tropiący. De Securitate et Defensione. Bezpiecz. Obron. 1, 58-71.

Boruta A., Bagińska B., Kurek A., Dzierżanowska-Góryń D., 2018. Analiza użytkowości rozrodczej labradorów z certyfikatem użytkowości. Rocz. Nauk. PTZ 14(4), 21-17.

Courreau J.-F., Langlois B., 2005. Genetic parameters and environmental effects which characterize the defence ability of the Belgian shepherd dog. Appl. Anim. Behav. Sci. 91, 233-245.

Gardianova I., Helclova M., Korab S., Hradecka L., 2013. Tracking, obedience and defence between Belgian Shepherd Malinois and German Shepherd Dog. J. L. Sci. 7(1), 89-91.

Goleman M., 2011. Owczarek niemiecki jakiego nie znamy. Prz. Hod. 7, 18-20.

Grondkowska A., Kuźnicka E., 2011. Możliwości wykorzystania psów pasterskich w agroturystyce. Prz.. Hod. 6, 28-32.

Jones A.C., Gosling S.D., 2005. Temperament and personality in dogs (Canis familiaris): A review and evaluation of past research. Appl. Anim. Behav. Sci. 95, 1-53.

Kamieniak J., Mazurkiewicz T., Tietze M., 2015. Modyfikujący wpływ człowieka na zachowanie się psa domowego. Życie Wet. 90(6), 369-371.

Karpiński M., Mazurkiewicz T., Czyżowski P., Goleman M., 2012. Zabawa jako podstawowy czynnik dobrostanu kształtujący prawidłowe zachowania psychosomatyczne i socjalne psów. Med. Weter. 68(4), 218-221.

Lipka M., Strychalski J., Jastrzębska A., Gugołek A., 2017. The performance of German shepeherd and Belgian shepherd Malinois dogs in obedience, obstacle course, defence and tracking tests. P. J. Nat. Sci. 32(3), 451-459.

Regulamin testów psychicznych. Główna Komisja Szkolenia psów. Zarząd Główny, Związek Kynologiczny w Polsce, https:/www.zkwp-szkolenia.pl/images/komisje/Uzytkowe/ regulaminy/regula-min_test $\% \mathrm{C} 3 \% \mathrm{~B} 3 \mathrm{w} \_$psychicznych_dla_ps $\% \mathrm{C} 3 \% \mathrm{~B} 3 \mathrm{w} \_\mathrm{r} \% \mathrm{C} 4 \% 99 \mathrm{kaw}$ owych.pdf [dostęp 22.10.2020].

Svartberg K., 2002. Shyness-boldness predicts performance in working dogs. Appl. Anim. Behav. Sci. 79, 157-174.

Walczak M., Bury-Burzymski P., Walasek A., 2016. Metody oceny zachowania się psów pracujących w świetle badań naukowych. Kwart. Polic. 3, 42-48.

Wzorzec FCI nr 15 owczarek belgijski. Międzynarodowa Federacja Kynologiczna. 
Paulina Lipińska ${ }^{1,3}$, Jarosław Kamieniak ${ }^{2}$, Małgorzata Goleman ${ }^{2}$

\title{
Wpływ wybranych czynników na częstość występowania i skuteczność eliminacji zachowań niepożądanych u psów
}

The influence of selected factors on the frequency of the manifestation and the effectiveness of elimination undesired behaviors in dogs

\begin{abstract}
Wstęp
Zachowania uznawane przez właścicieli psów za niepożądane bardzo często są typowe dla tego gatunku, a ich przejawianie umożliwia zwierzętom osiągnięcie komfortu behawioralnego. Są to jedne z najczęstszych problemów, z jakimi muszą się zmagać właściciele psów. Jest to również jedna z głównych przyczyn eutanazji, porzucania oraz oddawania zwierząt do schronisk [Kwan i Bain 2013]. Bardzo często czynnikiem powodującym wystąpienie problematycznych zachowań u psów może być tryb życia ich właścicieli, którzy nie potrafią w odpowiedni sposób zająć się swoimi pupilami [Kudła 2012]. Na tym tle pojawiają się różne trudności w interakcjach człowiek-zwierzę. Mobilizują one właścicieli do udziału wraz z psem w szkoleniu, które ma wyeliminować problematyczne zachowania i zapobiegać ich występowaniu w przyszłości. Jednak wiele osób, zanim zasięgnie porady specjalisty, próbuje wyeliminować problem na własną rękę, stosując nieodpowiednie metody pracy ze zwierzęciem. W takich sytuacjach brak podstawowej wiedzy dotyczącej zasad uczenia się i szeroko pojętego modyfikowania zachowania może skutkować pogłębieniem problemu. Ponadto nieprawidłowe podejście właściciela do opieki nad psem oraz jego szkolenia może mieć wpływ na występowanie zachowań niepożądanych.

Mówiąc o zachowaniach zwierząt, należy rozpocząć od określenia, czy mamy do czynienia z normą, czy z patologią [Cichoń 2007]. Zachowania niepożądane lub nie do zaakceptowania w kategoriach społecznych często są zwykłymi zachowaniami zwierząt. Nieznajomość naturalnego repertuaru zachowań psa przez jego opiekunów może skutkować niezaspokajaniem jego potrzeb, jak również odbieraniem naturalnych zachowań jako zachowań niepożądanych z punktu

\footnotetext{
1 Uniwersytet Przyrodniczy w Lublinie, Wydział Nauk o Zwierzętach i Biogospodarki, Studenckie Koło Naukowe Nauk o Zwierzętach i Biogospodarki - Sekcja Kynologiczna

${ }^{2}$ Uniwersytet Przyrodniczy w Lublinie, Wydział Nauk o Zwierzętach i Biogospodarki, Katedra Etologii Zwierząt i Łowiectwa

3 paulina.lipinska100@wp.pl
} 
widzenia właściciela. Stres spowodowany niekorzystnym oddziaływaniem środowiska oraz brak umiejętności postępowania z psami mogą doprowadzić do powstania i utrwalenia $\mathrm{w}$ ich etogramie zachowań nietypowych, często niepożądanych [Kamieniak i in. 2015]. Dlatego bardzo istotne jest rozróżnienie zaburzenia zachowania od zachowań typowych dla gatunku, lecz niepożądanych przez opiekuna psa. Można stwierdzić, że anomalią jest zachowanie zwierzęcia, które nie jest zgodne z normami zachowań jego gatunku [Kosińska 2003]. Określenie ,zaburzenia zachowania" u psów jest niejednokrotnie nadużywane [Łapińska 2016]. Stosując ten termin, właściciele psów często mówią o problemach z zachowaniem psa wynikających z niewłaściwego wychowania, takich jak: gryzienie przedmiotów, ciągnięcie na smyczy, ucieczki na spacerach, żebranie o jedzenie.

Przyczyny powstawania zachowań niepożądanych są niejednokrotnie złożone i trudne do określenia. Duży wpływ na kształtowanie osobowości psa ma doświadczenie właściciela w wychowaniu i utrzymaniu psa [Cichoń 2008]. Nowi właściciele szczeniąt, którzy często nie mają doświadczeń i wiedzy na temat potrzeb oraz zachowania swoich zwierząt, nie umieją zapewnić im odpowiednich warunków do rozwoju oraz przystosowania do życia w ludzkim społeczeństwie. Stosując niewłaściwe, bardzo często uświęcone tradycją metody, powodują występowanie u psów zachowań niepożądanych lub zwiększenie intensywności już obecnych [Kłosiński 2007]. Istotne jest, aby oprócz zapewnienia psu jedzenia, schronienia i opieki medycznej, również zaspokoić jego potrzeby behawioralne i społeczne. Intensywny tryb życia prowadzony przez właścicieli tych zwierząt coraz częściej powoduje skrócenie czasu poświęcanego na zaspokojenie podstawowych potrzeb psów, takich jak kontakt $\mathrm{z}$ człowiekiem oraz spożytkowanie energii. Takie postępowanie często prowadzi do rozwoju zaburzeń w zachowaniu zwierząt [Kudła 2012].

Każde zwierzę potrzebuje odpowiedniej ilości ruchu. W wyniku niespełnienia tej potrzeby najczęściej pies sam będzie próbował radzić sobie z frustracją, w konsekwencji wyładowując nadmiar energii na najbliższym otoczeniu [Witkowska i Chudalewska 2014]. Nieumiejętne stosowanie przez właściciela nagradzania i karania może również powodować wzmocnienie niepożądanych zachowań. Zwierzęta nie powtarzają zachowań, za które nie są w żaden sposób nagradzane, natomiast powtarzają te, za które dostają nagrodę [Tynes 2012]. Dlatego bardzo ważne jest, aby wystrzegać się przypadkowego nagradzania. Nieodpowiednie użycie kary może prowadzić do powstawania zaburzeń zachowania lub pogłębiania ich. Kara, która zostaje wymierzona w momencie przyłapania psa „na gorącym uczynku”, może powodować nasilenie przeżywanego przez niego lęku [Nack 2001]. Właściciele obawiają się warczenia oraz pokazywania zębów przez psy, dlatego nie pozwalają im na wykazywanie takich zachowań [Łapińska 2016]. Częstą reakcją właściciela na prezentację tych zachowań przez psa jest jego karcenie. Kiedy sygnały ostrzegawcze wysyłane przez psa nie dają pożądanego rezultatu, może on nauczyć się, że tylko zachowanie agresywne daje moż- 
liwość zakończenia stresującej go sytuacji [Kudła 2006]. Jest to agresja wyuczona (instrumentalna).

Wielu badaczy próbowało stwierdzić, czy rasa, wiek psa oraz udział w szkoleniu mają wpływ na częstość przejawiania przez psy zachowań niepożądanych, jednak wyniki tych badań nie pokrywają się [Wright $i$ in. 1987, Bradshaw $i$ in. 2002, Bennett i Rohlf 2007, Blackwell i in. 2008, Gazzano i in. 2008, Jagoe i Serpell 1996, Kubinyi i in. 2009,]. Uwzględniając fakt, iż skuteczność stosowania warunkowania instrumentalnego $\mathrm{w}$ kształtowaniu zachowania psów przez ich właścicieli nie została jednoznacznie potwierdzona, podjęto temat badawczy, którego celem było określenie u właścicieli psów stanu wiedzy dotyczącej warunkowania instrumentalnego i umiejętności stosowania jego zasad w praktyce, jak również stwierdzenie, czy rasa i wiek psa, sposób postępowania jego właściciela oraz udział w szkoleniu mogą wpływać na przejawianie przez psa zachowań niepożądanych.

\section{Badania wlasne}

W badaniach ankietowych wzięło udział 130 właścicieli psów, wśród nich znalazło się 113 kobiet i 17 mężczyzn. Wymienione przez respondentów rasy posiadanych psów sklasyfikowano do grup wg kryteriów przyjętych przez Międzynarodową Federację Kynologiczną (FCI). Największą grupę 57 psów stanowiły psy nierasowe, 21 psów należało do grupy VIII, 16 do grupy I, 12 do grupy II, 10 psów do grupy III, 9 do IX, 2 do VI i po jednym psie do grup IV, V i X. Zachowania niepożądane wymienione przez właścicieli dla ułatwienia analizy zostały podzielone na kategorie, takie jak: zachowania agresywne, nadpobudliwość, skakanie na ludzi, ciągnięcie na smyczy, nieposłuszeństwo, niszczenie przedmiotów w domu podczas nieobecności właściciela, zachowania lękowe, żebranie oraz nadmierna wokalizacja. W ankiecie właścicielom psów zadano ogólne pytania dotyczące charakterystyki ich samych oraz psów. Zapytano, czy pies ukończył jakieś szkolenie, jeśli tak, to jakie. W ankiecie znalazły się także pytania ogólne dotyczące wiedzy właścicieli na temat warunkowania instrumentalnego/sprawczego. Analizowano, czy znajomość przez respondentów zasad stosowania warunkowania instrumentalnego ma wpływ na zmniejszenie wykazywania zachowań niepożądanych przez ich psy oraz prześledzono efekty stosowania tej formy uczenia się w praktyce. Zbadano również, czy rasa i wiek psa, poddanie go szkoleniu oraz rodzaj szkolenia mają wpływ na przejawianie zachowań niepożądanych. Zadano również pytania odnośnie do trzech wybranych zachowań niepożądanych, takich jak: skakanie na właściciela, żebranie przy stole i próba zwrócenia na siebie uwagi przez psa. Analizowano, w jaki sposób właściciel reagował na te zachowania oraz czy dana reakcja wpływała na zaprzestanie wykazywania zachowania niepożądanego, czy nie. Dokonano oceny zacho- 
wania psów, przyznając im punkty w skali od 1 do 3 , zależnie od tego, czy przejawiały zachowania niepożądane (1 punkt), czy nie (3 punkty).

\section{Wpływ posiadania wiedzy na temat warunkowania instrumentalnego i umiejętności stosowania jego zasad w praktyce}

Wśród objętych ankietą właścicieli psów $60 \%$ nie wiedziało, co to jest warunkowanie instrumentalne/sprawcze. Przeprowadzone badania wykazały, że posiadanie lub nie przez właściciela wiedzy na temat warunkowania instrumentalnego nie miało wpływu na zmniejszenie częstości wykazywania przez jego psa zachowań niepożądanych. Istotnym czynnikiem decydującym o skuteczności działań podejmowanych przez właścicieli w celu wyeliminowania u psów zachowań niepożądanych były zdecydowanie i konsekwencja w stosowaniu kar i nagród. W przypadku podchodzenia konsekwentnie do próby wygaszenia zachowania niepożądanego 64 właścicieli $(49,2 \%)$ zaznaczyło odpowiedź ,raczej tak”, 54 (41,5\%) „zdecydowanie tak”, a 12 (9,2\%) zaznaczyło odpowiedź „nie”. Psy respondentów, którzy postępowali z czworonogami zdecydowanie i konsekwentnie, wykazywały mniej zachowań niepożądanych. W innych przypadkach zachowania niepożądane pojawiały się u psów bardzo często.

Analizując wpływ poziomu konsekwencji w pracy z psem na efektywność wyeliminowania zachowań niepożądanych, wyrażony liczbą punktów przyznanych według metody własnej, stwierdzono, że brak konsekwencji właściciela w stosowaniu kar i nagród był najbardziej skuteczny i wpływał na zmniejszoną częstotliwość przejawiania niepożądanego zachowania w przyszłości. W przypadku tego wyniku należy brać pod uwagę subiektywizm opinii respondentów, którzy w swoich opiniach nie zawsze mogli być wiarygodni. Ponadto różnice w średnich wyliczonych dla poszczególnych poziomów konsekwencji były niewielkie i statystycznie nieistotne.

\section{Wpływ rasy}

Analizując wpływ rasy, stwierdzono, że zachowania niepożądane nieznacznie częściej pojawiały się u psów nierasowych $(63,16 \%)$, niespełniających kryteriów kwalifikujących do określonej rasy uznanej przez FCI, w porównaniu z rasowymi $(57,53 \%)$. Wśród psów rasowych najczęściej zachowania takie występowały u przedstawicieli II grupy $(91,67 \%)$, a najrzadziej u przedstawicieli IX grupy FCI (22,22\%). Również Bennett i Rohlf [2007] wykazały w swoim badaniu, że psy nierasowe w porównaniu $\mathrm{z}$ rasowymi były uważane za bardziej nieposłuszne. Badania własne wykazały wpływ przynależności do konkretnej grupy rasowej na częstość przejawiania zachowań niepożądanych. Odmienne wyniki uzyskali natomiast Blackwell i in. [2008], którzy wykazali brak wpływu, jaki ma rodzaj rasy na wykazywanie zachowanie pożądanych. 


\section{Wplyw wieku psa}

Czynnikiem istotnie wpływającym na frekwencję zachowań niepożądanych był także wiek zwierząt. Najczęściej zachowania niepożądane występowały u psów powyżej 3. roku życia (43\%), następnie w wieku 1-3 lat (28\%), 6-12 miesięcy (25\%), najrzadziej zaś u psów w wieku poniżej 6 miesięcy (4\%). W swoim badaniu Wright i in. [1987] również wykazali, że średnia wieku psów wykazujących problematyczne zachowania wynosiła 3,4 roku. Na taki wynik niewątpliwie wpływ miał fakt, że psy w tym wieku stanowiły $50 \%$ całej grupy zwierząt objętych badaniami. Dlatego w innych grupach wiekowych reprezentowanych mniej licznie zachowania niepożądane występowały rzadziej. Wynik ten może też być spowodowany faktem, iż właściciele młodszych psów mogą bagatelizować problem, który dopiero $\mathrm{z}$ wiekiem psa może się nasilać lub stać się bardziej uciążliwy. Odmienne wyniki uzyskali Bradshaw i in. [2002], stwierdzając większą liczbę niepożądanych zachowań u psów młodszych.

\section{Wplyw udziału w szkoleniu}

Spośród właścicieli psów 87 (66,9\%) nie ukończyło z psem żadnego szkolenia. $Z$ pozostałych 43 respondentów, którzy ukończyli szkolenie, 30 osób $(69,8 \%)$ ukończyło z psem szkolenie podstawowego posłuszeństwa, $16(37,2 \%)$ przedszkole dla szczeniąt i $8(18,6 \%)$ szkolenie sportowe/specjalistyczne. Udział w szkoleniu oraz jego rodzaj nie wpłynęły na zmniejszenie częstości przejawiania przez psy zachowań niepożądanych; $63 \%$ psów, które ukończyły szkolenie, wykazywało takie zachowania. Zgodne z tym są badania Blackwell i in. [2008], które wykazały, że rodzaj szkolenia nie wpływał znacząco na całkowitą liczbę niepożądanych zachowań przejawianych przez psy. Również Gazzano i in. [2008] stwierdzili, że uczęszczanie psów na zajęcia podstawowego posłuszeństwa nie prowadzi do zmniejszenia częstości występowania u nich niepożądanych zachowań. Analizując wpływ udziału w szkoleniu na wykazywanie poszczególnych zachowań niepożądanych, stwierdzono, że zachowania agresywne, ciągnięcie na smyczy, nieposłuszeństwo, zachowania lękowe, żebranie i nadmierna wokalizacja przeważały u psów, które nie ukończyły żadnego szkolenia. Gazzano i in. [2008] wykazali, że rady dla właścicieli dotyczące ich zachowania wobec szczeniaków i odpowiedniego wychowania prowadziły do zmniejszenia liczby psów przejawiających zachowania niepożądane. Być może na zajęciach przedszkola dla szczeniąt, w którym brali udział respondenci, nie zostali należycie poinformowani odnośnie do odpowiedniego postępowania z psem. Wright $\mathrm{i}$ in. [1987] w swoim badaniu stwierdzili, że udane ukończenie szkolenia miało niewielki wpływ na rozwiązywanie problemów związanych z zachowaniem. W przeciwieństwie do tego Kubinyi i in. [2009] wykazali, że psy właścicieli, którzy uczęszczali na szkolenia, były bardziej posłuszne i wykazywały mniej niepożądanych zachowań. Możliwe, że właściciele, którzy zainwestowali czas i pieniądze na szkolenia, oceniają swoje psy jako lepiej zachowujące się, ponie- 
waż oczekują, że tak się stanie lub mają większą wiedzę o „,normalnych” zachowaniach psów [Bennett i Rohlf 2007]. Być może na taki wynik wpływ mają zastosowane metody szkolenia, jednak nie uzyskano informacji na ten temat. Hiby i in. [2004] nie znaleźli żadnych istotnych korelacji pomiędzy różnymi metodami szkolenia psów a częstością występowania zachowań niepożądanych, jednak zwiększona liczba metod opartych na karze miała niewielki wpływ na przejawianie problematycznych zachowań. Jagoe i Serpell [1996] wykazali, że właściciele są skłonni do zabierania wyjątkowo nieposłusznych i/lub nadpobudliwych psów na zajęcia, jednak formalny trening posłuszeństwa nie jest efektywnym sposobem ich zniwelowania.

\section{Wpływ różnych reakcji właściciela na wybrane zachowania niepożądane}

Badania własne wykazały, że podczas żebrania psa przy stole oraz skakania na właściciela najczęstszym zachowaniem człowieka było ignorowanie zachowania zwierzęcia (odpowiednio 57\% i 48,2\%), jednak najbardziej efektywnym według respondentów sposobem wpływającym na zaprzestanie żebrania było odpychanie psa (74\%), natomiast w przypadku skakania na właściciela i chęci zwrócenia na siebie uwagi najbardziej efektywnym sposobem na zaprzestanie tych zachowań było głaskanie psa (odpowiednio 79\% i 100\%). Być może w tych sytuacjach dochodziło jedynie do tymczasowego hamowania zachowań niepożądanych, interpretowanego przez właścicieli jako całkowite wyeliminowanie problemu [Herron i in. 2009]. Analiza wartości wymiernego wskaźnika, jakim jest liczba punktów przyznawanych psom za określone formy zachowania się (zgodnie z przyjętą metodyką), wykazała, że w celu wyeliminowania zachowania $\mathrm{w}$ postaci żebrania przy stole najbardziej efektywne było głaskanie oraz ignorowanie psa. Mimo faktu, iż najwyższa średnia punktacja wystąpiła dla reakcji właściciela w postaci „krzyczenia”, nie można uznać tego wyniku za obiektywny i miarodajny, ze względu na niewielką liczbę takich wariantów odpowiedzi uzyskanych z ankiet. Gacsi i in. [2004] w swoich badaniach opisali, że na początku próby wyeliminowania żebrania o jedzenie ignorowanie psa może nie przynosić efektu, ponieważ pies pamięta, że wcześniej zawsze coś otrzymał. Przed rozpoczęciem wygaszania niepożądane zachowanie nasila się przez pewien czas, zanim zwierzę ostatecznie przestaje próbować [Tynes 2012]. Jest to tzw. wybuch związany z wygaszaniem, po którym następuje zmniejszenie częstotliwości reakcji. Wygaszenie reakcji warunkowej, która jest dobrze utrwalona przebiega powoli, natomiast wznowienie wygaszonej reakcji w tej samej sytuacji następuje niemal natychmiast [Zieliński i Werka 2005]. Dlatego podczas wygaszania zachowania istotną rolę pełni konsekwencja właściciela. 


\section{Podsumowanie}

Znajomość zasad uczenia się zwierząt jest bardzo istotna w kształtowaniu ich zachowania, jednak wśród właścicieli psów nie jest ona powszechna. Wyszczególnione zachowania niepożądane analizowane w niniejszej pracy nie dla każdego stanowią problem. Dlatego przyjętą przez właścicieli psów ich klasyfikację do tego typu zachowań (niepożądanych) należy uznać za subiektywną. Kluczową rolę przy przejawianiu zachowań niepożądanych stanowi warunkowanie instrumentalne, dzięki któremu zwierzę uczy się zależności określonej reakcji od określonej sytuacji. Należy pamiętać, że modyfikacja zachowań psa jest procesem złożonym i długotrwałym, więc podstawą sukcesu jest konsekwencja właściciela. Umożliwienie psu prezentacji jego naturalnych zachowań jest wysoce nagradzające, dlatego możemy wykorzystać to podczas szkolenia lub modyfikacji niepożądanych zachowań [Kłosiński 2008]. Ignorowanie psa podczas prezentacji niechcianych zachowań również jest jednym ze sposobów ich eliminacji. W przypadku żebrania przez psa o jedzenie wszystkie osoby $\mathrm{w}$ domu muszą ignorować żebranie zwierzęcia, ponieważ tylko wtedy istnieje szansa na całkowite zaprzestanie prezentowania takiego zachowania [Tynes 2012].

\section{Bibliografia}

Bennett P.C., Rohlf V.I., 2007. Owner-companion dog interactions: Relationships between demographic variables, potentially problematic behaviours, training engagement and shared activities. Appl. Anim. Behav. Sci. 102, 65-84. https://doi.org/10.1016/j.applanim.2006.03.009

Blackwell E.J., Twells C., Seawright A., Casey R.A., 2008. The relationship between training methods and the occurrence of behavior problems, as reported by owners, in a population of domestic dogs. J. Vet. Behav. 3, 207-217. https://doi.org/10.1016/j.jveb.2007.10.008

Bradshaw J.W.S., McPherson J.A., Casey R.A., Larter I.S., 2002. Aetiology of separation-related behavior in domestic dogs. Vet. Rec. 151, 43-46. http://dx.doi.org/10.1136/vr.151.2.43

Cichoń R., 2007. Wiedza o zachowaniu podstawą sukcesu. Wet. Prakt. 4(2), 86-87.

Cichoń R., 2008 Agresywne zachowania psów. Wybrane elementy diagnostyki i terapii. Wet. Prakt. 5(2), 88-89.

Gazzano A., Mariti C., Alvares S., Cozzi A., Tognetti R., Sighieri C., 2008. The prevention of undesirable behaviors in dogs: effectiveness of veterinary behaviorists' advice given to puppy owners. J. Vet. Behav. 3, 125-133. https://doi.org/10.1016/j.jveb.2008.04.004

Herron M.E., Shofer F.S., Reisner I.R., 2009. Survey of the use outcome of confrontal and nonconfrontal training methods in client-owned dogs showing undesirable behaviors. Appl. Anim. Behav. Sci. 117, 47-54. https://doi.org/10.1016/j.applanim.2008.12.011

Hiby E.F., Rooney N.J., Bradshaw J.W.S., 2004. Dog training methods: their use, effectiveness and interaction with behaviour and welfare. Anim. Welf. 13, 63-69.

Jagoe A., Serpell J., 1996. Owner characteristics and interactions and prevalence of canine behaviour problems. App. Anim. Behav. Sci. 47, 31-42. https://doi.org/10.1016/0168-1591(95)01008-4

Kamieniak J., Mazurkiewicz T., Tietze M., 2015. Modyfikujący wpływ człowieka na zachowanie się psa domowego. Życie Wet. 90(6), 369-371.

Kłosiński A., 2007. Behawioryzm - moda czy konieczność? Mag. Wet. 16(1), 30, 32. 
Kłosiński A., 2008. Współczesny model rozumienia zaburzeń zachowania zwierząt towarzyszących oraz nowoczesny model terapii behawioralnej w lecznicy weterynaryjnej. Mag. Wet. 12(03) 244-245.

Kosińska J., 2003. Zaburzenia psychiczne i najczęstsze problemy z zachowaniem psów. Mag. Wet. 12(82), 46-50.

Kubinyi E., Turcsan B., Miklosi A., 2009. Dog and owner demographic characteristics and dog personality trait associations. Behav. Proc. 81, 392-401. https://doi.org/10.1016/j.beproc.2009.04.004

Kudła J., 2006. Klasyfikacja i czynniki wpływające na agresywne zachowanie u psów. Cz. I. Mag. Wet. 15(118), 44-46.

Kudła J., 2012. Najczęstsze zaburzenia zachowania u psów i kotów - algorytmy pierwszej pomocy. Cz. II. Mag. Wet. 21(187), 1329-1338.

Kwan J.Y., Bain M.J., 2013. Owner attachment and problem behaviors related to relinquishment and training techniques of dogs. J. Appl. Anim. Welf. Sci. 16, 168-183. https://doi/10.1080/ 10888705.2013.768923.

Łapińska J., 2016. Różnicowanie zaburzeń zachowania u psów. VetPersonel 2, 48-50, 2016.

Nack R.A., 2001. Jak radzić sobie z lękiem przed rozłąką u psów. Wet. Dypl. 2(2), 69-75.

Tynes V.V., 2012. W jaki sposób pomóc klientom oduczyć psy żebrania o jedzenie? Wet. Dypl. 13(6), 42-43.

Witkowska O., Chudalewska K., 2014. Lęk separacyjny u psów. Życie Wet. 89(8), 682-684.

Wright J.C., Nesselrote M.S., 1987. Classification of behavior problems in dogs: distributions of age, breed, sex and reproductive status. Appl. Anim. Behav. Sci. 19, 169-178. https://doi.org/10.1016/0168-1591(87)90213-9

Zieliński K., Werka T., 2005. Mózg a zachowanie. Wyd. Nauk. PWN, Warszawa. 
Patrycja Małysz ${ }^{1,3}$, Martyna Frątczak ${ }^{1}$, Elżbieta Wnuk-Pawlak ${ }^{2}$

\section{Wrzody jako choroba cywilizacyjna koni}

Gastric ulcers as a civilization disease among the horses

Coraz częściej pada stwierdzenie, że zespół owrzodzenia żołądka koni (equine gastric ulcer syndrome - EGUS) jest chorobą cywilizacyjną. Trudno się z tym nie zgodzić, biorąc pod uwagę częstotliwość występowania EGUS wśród koni, która wynosi u koni sportowych od 40 do 100\%. [Ribeiro i in. 2016, 2019]. Jak podaje Encyklopedia PWN [https://encyklopedia.pwn.pl/haslo/cywilizacyjne-choroby;3888921.html], choroby cywilizacyjne są schorzeniami związanymi z ujemnymi skutkami życia w warunkach wysoko rozwiniętej cywilizacji. Rozwój cywilizacji dał ludziom wiele korzyści, również w jeździectwie, gdzie m.in. mamy nieograniczony dostęp do różnych mieszanek paszowych oraz suplementów diety dla naszych koni, co będzie przedstawione poniżej w zestawieniach argumentujących postawioną tezę.

Poznanie podstawowej anatomii jest ważnym czynnikiem prowadzącym do zrozumienia istoty wrzodów. Jak podają Przespolewska i in. [2014], koń ma żołądek jednokomorowy złożony, który charakteryzuje się tym, że wkracza do niego z przełyku nabłonek wielowarstwowy płaski. Jego zasięg wyznacza obszar bezgruczołowy błony śluzowej. Jest to tzw. część bezgruczołowa żołądka (pars nonglandularis), która u konia zajmuje prawie połowę powierzchni żołądka. Pozostała część nosi nazwę części gruczołowej (pars glandularis), gdyż jest pokryta nabłonkiem jednowarstwowym cylindrycznym z gruczołami. Części te są od siebie oddzielone brzegiem sfałdowanym (margoplicatus). Ściana żołądka jest zbudowana z trzech zasadniczych warstw: błony śluzowej (tunica mисоsa), mięśniowej (tunica muscularis) i surowiczej (tunica serosa). Między błoną śluzową a błoną mięśniową leży tkanka podśluzowa (tela submucosa), która umożliwia błonie śluzowej tworzenie fałdów pozwalających żołądkowi na rozszerzanie się wraz z napełnianiem. Komórki nabłonka wytwarzają śluzową wydzielinę, która poprzez pokrywanie powierzchni błony śluzowej chroni ją przed działaniem enzymów trawiennych oraz przed urazami spowodowanymi ostrymi częściami pokarmu. Gruczoły żołądka produkują kwas solny oraz enzymy trawienne,

\footnotetext{
${ }^{1}$ Uniwersytet Przyrodniczy w Lublinie, Wydział Nauk o Zwierzętach i Biogospodarki, Studenckie Koło Naukowe Nauk o Zwierzętach i Biogospodarki, Sekcja Hipologiczna

${ }^{2}$ Uniwersytet Przyrodniczy w Lublinie, Wydział Nauk o Zwierzętach i Biogospodarki Katedra Hodowli i Użytkowania Koni

3 patrycja.malysz98@gmail.com
} 
które są podstawowymi składnikami soku żołądkowego. Dodatkowo gruczoły produkują śluz chroniący błonę śluzową. Błona mięśniowa składa się z dwóch warstw mięśni. Błona surowicza natomiast jest dziełem otrzewnej trzewnej. $\mathrm{Na}$ krzywiźnie większej żołądka przechodzi ona w sieć większą, natomiast od krzywizny mniejszej przechodzi w sieć mniejszą.

Andrews i in. [1999a] na łamach „Equine Veterinary Education” pierwszy raz użyli terminu zespół owrzodzenia żołądka koni (equine gasctric ulcer syndrome - EGUS), by opisać problemy wrzodowe dotykające koni. Pojęcie EGUS niestety było często nadużywane i zbyt powierzchownie dotykało problemu. Dlatego, by bardziej szczegółowo mówić o problemach wrzodowych przewodu pokarmowego koni, Sykes i in. [2015] zaproponowali podział na chorobę płaskonabłonkową żołądka koni (equine squamous gastric disease - ESGD) oraz chorobę gruczołową żołądka koni (equine glandular gastric disease - EGGD). Dodatkowo ESGD została podzielona na chorobę pierwotną, związaną z intensywnym użytkowaniem zwierząt o normalnie funkcjonującym przewodzie pokarmowym, oraz na chorobę wtórną, gdzie opóźnione jest opróżnianie żołądka z innych przyczyn chorobowych.

W swoich badaniach Sykes i in. [2015], Murray i in. [1996] oraz Andrews i in. [2017] poruszyli bardzo ważny problem, od którego należy zacząć, mówiąc o przyczynach występowania chorób wrzodowych koni. Koń jest roślinożercą, który w naturze w ciągu dnia przemieszczał się i pobierał pasze bogate w błonnik i ubogie w skrobię. Potrafił dziennie żerować przez 18 godzin. Dlatego jego układ pokarmowy przystosowany jest do przyjmowania małych, lecz częstych dawek paszy. Bass i in. [2018] sprawdzali wpływ częstotliwości karmienia na owrzodzenie żołądka. Konie w badaniu zostały podzielone na dwie grupy - obie grupy dostawały łącznie taką samą ilość paszy, jednak pierwsza grupa była karmiona dwukrotnie w ciągu dnia, druga natomiast dostawała paszę co godzinę przez 20 godzin. Konie $\mathrm{w}$ trakcie badania były normalnie użytkowane. Autorzy badania zauważyli, że u zwierząt karmionych mniejszymi dawkami, ale częściej, w ciągu 60 dni nie pogorszył się stan zdrowotny, natomiast wśród koni karmionych systemem tradycyjnym odnotowano znaczny wzrost wskaźników chorób wrzodowych w dniach 30. i 60. Stwierdzono, że przerwa pomiędzy posiłkami przekraczająca 6 godz. zwiększa prawdopodobieństwo zachorowania na chorobę płaskonabłonkową żołądka koni. Do tego samego wniosku doszli również Bell i in. [2007] oraz Murray i Schusser [1993]. W swoich badaniach stwierdzili, że u koni karmionych rzadko, gdy między poszczególnymi posiłkami jest długa przerwa, pH żołądka jest zdecydowanie niższe niż w przypadku koni karmionych częściej. Najczęściej problem ograniczania pobierania paszy dotyka koni sportowych, które z racji treningu mają długie przerwy między posiłkami. Wykazali oni również, że konie żyjące w zamknięciu, mimo dostępu do paszy ad libitum, spędzają na jedzeniu zdecydowanie mniej czasu niż konie będące na pastwisku.

Współczesne diety bardzo często opierają się na wysokiej zawartości skrobi. Dobrym przykładem jest opis konia arabskiego biorącego udział w gonitwach. 
Kaya-Karasu i in. [2016] podają, że osobnik ten spożywał dziennie 3,08 g/kg m.c. mączki skrobi, a pozostałe pasze zajmowały jedynie $40 \%$ diety. W badaniu duńskiego zespołu stwierdzono, że zwierzęta przyjmujące dziennie więcej niż $2 \mathrm{~g} / \mathrm{kg}$ m.c. skrobi są narażone na choroby wrzodowe żołądka [Luthersson i in. 2009]. Jak stwierdził Kaya-Karasu i in. [2016], prawdopodobnie zwiększona ilość skrobi powoduje zwiększoną produkcję lotnych kwasów tłuszczowych (VFA) w żołądku, które zmniejszają kwasowość żołądka, bądź dochodzi do spowolnienia opróżniania żołądka, co skutkuje zwiększeniem czasu ekspozycji błon śluzowych żołądka na lotne kwasy thuszczowe oraz na HCl. Niedobór PGE2 zwiększa podatność błony śluzowej na powstawanie wrzodów [Kobayashi i Arakawa 1995]. Zespół pod kierownictwem Luthersson i in. [2009] doszedł do wniosku, że spożycie skrobi, które przekracza $0,2 \%$ masy ciała na dzień lub $0,1 \%$ masy ciała na posiłek powodowało wzrost liczby ciężkich zmian żołądkowych i skutkowało wystąpieniem ESGD. Frombelle i in. [2003] zaobserwowali natomiast, że niższe stężenie kwasu mlekowego i wyższe stężenie VFA w treści żołądkowej występuje wśród koni karmionych dietą wysokoskrobiową w porównaniu z innymi końmi.

Koń chorujący na EGUS może wykazywać objawy choroby, jednak tylko badanie gastroskopowe potwierdza występowanie wrzodów. Konie z tym schorzeniem mogą mieć mniejszy apetyt lub być kapryśne w kwestii paszy. W związku z tym można zauważyć spadek masy ciała oraz ogólnej kondycji. Obserwuje się również częste kolki [Andrews i Nadeau 1999b]. Często mówi się też o występowaniu apatii, jednak bardzo wiele chorych osobników nie wykazuje oczywistych objawów choroby [Jones 2006]. Opisywany koń czystej krwi arabskiej żywiony paszą wysokoskrobiową miał gorsze wyniki gonitw oraz częściej niż inne konie ziewał, natomiast apetyt miał dobry, a sierść była lśniąca [Kaya-Karasu $i$ in. 2016].

Dionne [2003] w swoich badaniach zauważył, że ćwiczenia wpływają na zwiększenie produkcji kwasu żołądkowego, dodatkowo wystawiając błonę śluzową żołądka na kwaśne $\mathrm{pH}$, oraz prowadzą do zmniejszonego przepływu krwi w przewodzie pokarmowym.

Pośród koni będących w treningu skokowym stwierdzono chorobę wrzodową u 42,5\% badanych osobników [Ribeiro i in. 2019]. W trakcie badań okazało się, że różnica między końmi będącymi tylko w treningu a końmi uczestniczącymi również w zawodach jest niewielka, gdyż wynosiła odpowiednio $40 \%$ i 45\%. Dodatkowo autorzy skupili się na poziomie gastryny wśród dwóch grup koni i stwierdzili, że konie podczas zawodów mają wyższy poziom tego hormonu. Najprawdopodobniej jest to związane z opóźnionym opróżnianiem żołądka, co zostało spowodowane przez wysiłek fizyczny. Intensywne ćwiczenia powodują zwiększenie ciśnienia $\mathrm{w}$ jamie brzusznej poprzez pracę mięśni brzucha oraz ruchy oddechowe, co przyczynia się do ucisku żołądka [Lorenzo-Figueiras i Merritt 2002]. Opóźnienie opróżnienia żołądka skutkuje dłuższym kontaktem spożytego pokarmu z receptorami odpowiedzialnymi za uwalnianie gastryny [Smyth i in. 
1989]. Może dojść do zmieszania treści pokarmowej zawartej w żołądku, które wiąże się z zaburzeniem różnicy $\mathrm{pH}$ między częścią płaskonabłonkową a gruczołową żołądka.

Kolejne badanie zespołu pod kierownictwem Ribeiro [2016] dotyczyło wpływu treningu na bieżni na występowanie zmian wrzodowych w przewodzie pokarmowym. Do badania przystąpiły zdrowe konie; po odbytym okresie treningu stwierdzono, że wszystkie konie miały zmiany wrzodowe o różnej ilości i różnym nasileniu. Wyniki te potwierdziły hipotezę, że ćwiczenia na bieżni mogą skutkować rozwojem chorób wrzodowych u koni.

Następnym czynnikiem wpływającym na rozwój EGUS jest stres. Konie codziennie wystawione są na liczne sytuacje stresogenne - zmiana pory karmienia, trening czy zakłócenie spokoju. Szczególnie narażone na stres są konie sportowe, często wyjeżdżające na zawody, gdyż dodatkowy stres związany ze zmianą miejsca, nowymi zapachami, obcymi końmi silnie wpływa na zwierzęta. Podczas sytuacji stresowej dochodzi do uwalniania katecholamin, które odpowiadają za zwężenie naczyń krwionośnych, w związku z tym dochodzi do niedokrwienia błony śluzowej żołądka [Meirelles Filho i Andre 2000]. Skurcze żołądka mają na celu spowodowanie wypływu krwi z naczyń włosowatych. Przedłużone skurcze przyczyniają się do ograniczenia perfuzji i skutkują obrażeniami spowodowanymi przez kwas [Murray 1991].

Stężenie kortyzolu we krwi, ślinie i w kale stanowi miarę stresu krótkoterminowego, natomiast wpływ stresu średnio- i długoterminowego na organizm zwierzęcia mierzy się z użyciem włosia [Prinsloo i in. 2019]. Stres jest uważany za czynnik ryzyka dla EGGD [Scheidegger i in. 2017], natomiast w przypadku ESDG stwierdzono, że stężenie kortyzolu we włosiu było niższe u koni chorujących na ESGD oraz ujemnie skorelowane z nasileniem ESGD [Prinsloo $i$ in. 2019].

Z racji występowania EGUS na szeroką skalę poszukuje się sposobów na zapobieganie i tanie leczenie koni ze skłonnościami do wrzodów żołądka. Niektóre badania sugerowały, że karmienie koni lucerną ma korzystny wpływ na ich przewód pokarmowy. W porównaniu $\mathrm{z}$ większością surowców podawanych koniom lucerna ma wysoką wewnętrzną zdolność wiązania ze względu na wysokie stężenie wapnia i białka [Giger-Reverdin i in. 2002]. Julliand i in. [2018a] prowadzili badania dotyczące wpływu odwodnionej lucerny na skład bakteryjny i aktywność mikrobiologiczną ekosystemów żołądka i kału koni. Doszli do wniosku, że włączenie 16\% lucerny do racji zmodyfikowało głównie niektóre parametry biotyczne ekosystemów żołądka i kału u konia, ale nie zmieniło $\mathrm{pH}$ ani stężenia produktów końcowych fermentacji. Ten sam zespół naukowy opublikował kolejne badania, które miały na celu określenie wpływu suplementacji żywymi drożdżami na ekosystem żołądkowy koni karmionych paszami wysokoskrobiowymi [Julliand i in. 2018b]. Doszli oni do wniosku, że żywe drożdże mogą wpłynąć na zmianę niektórych parametrów ekosystemu żołądka koni. Zastosowanie drożdży w diecie wiązało się z obniżeniem poziomu bakterii amylolitycznych oraz bakterii, które wykorzystują mleczan. Jest to zgodne z liczbo- 
wym zmniejszeniem stężenia kwasu mlekowego, co prawdopodobnie wpłynęło na kwasowość środowiska.

Oleje roślinne wykazały działanie przeciwzapalne i przeciwwrzodziejące podczas licznych badań przeprowadzanych na szczurach i ludziach [Grant $\mathrm{i}$ in. 1988, Sammon i Iputo 2006], natomiast olej kukurydziany wywarł działanie terapeutyczne jedynie na błonę gruczołową [Martinez i in. 2016].

Bush i in. [2017] postawili pytanie, czy leczenie aloesem jest skuteczniejsze od powszechnie stosowanego omeprazolu. Po 4 tygodniach leczenia zauważono, że aloes $\mathrm{w}$ dawce $17,6 \mathrm{mg} / \mathrm{kg}$ masy ciała podskórnie dawał gorsze wyniki niż omeprazol, jednak w niewielkim stopniu wpływał na poprawę stanu koni. Płaskonabłonkowe wrzody rzadziej goiły się u koni wykazujących przedłużone opróżnianie żołądka.

Kolejnym badanym suplementem diety są algi, zawierające wiele drogocennych składników, które mogą być wykorzystywane w żywieniu zwierząt [Kandale $i$ in. 2011]. Wysoka zawartość wapnia w produktach $z$ alg (nawet powyżej 30\%) skłoniła zespół badaczy do sprawdzenia, czy można je wykorzystać w celu zapobiegania i łagodzenia EGUS u koni [Moir i in. 2016]. Badania wykazały, że algi wpłynęły na zmniejszenie przekrwienia błony śluzowej żołądka i na znaczne obniżenie się ilości wrzodów w grupie badanych koni. Wapń występujący w algach zmniejsza kwasowość treści żołądka i ściana żołądka nie jest podrażniana.

Coraz częściej właściciele koni podają im prebiotyki, których celem jest zachowanie równowagi drobnoustrojów w jelicie grubym. Fruktooligosacharydy w wyniku degradacji mikrobiologicznej powodują wzrost stężenia lotnych kwasów tłuszczowych, w tym kwasu masłowego. Cehak i in. [2019] zauważyli, że degradacja prebiotyków może rozpoczać się już w żołądku i wpłynąć na rozwój wrzodów. Zbadano również wpływ kwasu masłowego na błonę śluzową żołądka koni i zauważono zależność między jego poziomem a występowaniem zmian wrzodowych. Potwierdziło to wcześniejsze doniesienia o szkodliwości lotnych kwasów tłuszczowych na integralność błony śluzowej żołądka.

Powyższe stwierdzenia potwierdzają tezę, że zespół owrzodzenia żołądka koni jest chorobą cywilizacyjną koni. Jego szeroka skala występowania oraz czynniki wpływające na rozwój choroby wiążą się z rozwojem cywilizacji. Jedyną drogą do potwierdzenia występowania EGUS u koni jest gastroskopia oraz ocena pośmiertna. Można jednak zmniejszyć ryzyko wystąpienia wrzodów poprzez zapewnienie koniom dostępu do pastwisk, suplementowanie ich produktami bogatymi w wapń - algami oraz sieczką z lucerny. Zbilansowana dieta niskoskrobiowa oraz częste karmienie małymi porcjami również zmniejszają ryzyko wystąpienia wrzodów. 


\section{Bibliografia}

Andrews F.M., Bernard W., Byars D., Cohen N., Divers T., MacAllister C., McGladdery A,. Merritt A., Murray M., Orsini J., Snyder J., Vatistas N., 1999a. Recommendations for the diagnosis and treatment of equine gastric ulcer syndrome (EGUS). Equine Vet. Educ. 11, 262-272.

Andrews F.M., Nadeau J.A., 1999b. Clinical syndromes of gastric ulceration in foals and mature horses. Equine Vet. J. 31(29), 30-33. https://doi.org/10.1111/j.2042-3306.1999.tb05165.x

Andrews F.M., Larson C., Harris P., 2017. Nutritional management of gastric ulceration. Equine Vet. Educ. 29, 45-55. https://doi.org/10.1111/eve.12495

Bass L., Swain E., Santos H., Hess T., Black J., 2018. Effects of feeding frequency using a commercial automated feeding device on gastric ulceration in exercised quarter horses. J. Equine Vet. Sci. 64, 96-100. https://doi.org/10.1016/j.jevs.2018.02.005

Bell R.J.W., Mogg T.D., Kingston J.K., 2007. Equine gastric ulcer syndrome in adult horses: a review. N. Z. Vet. J. 55, 1-12. https://doi.org/10.1080/00480169.2007.36728

Bush J., Van Den Boom R., Franklin S., 2017. Comparison of aloe vera and omeprazole in the treatment of equine gastric ulcer syndrome. Equine Vet. J. 50, 34-40. https://doi.org/10.1111/evj.12706

Cehak A., Krägeloh T., Zuraw A., Kershaw O., Brehm R., Breves G., 2019. Does prebiotic feeding affect equine gastric health? A study on the effects of prebiotic-induced gastric butyric acid production on mucosal integrity of the equine stomach. Res.Vet. Sci. 124, 303-309. https://doi.org/10.1016/j.rvsc.2019.04.008

Dionne R.M., 2003. Gastric ulcers in standardbred racehorses: prevalence, lesion description, and risk factors. J. Vet. Intern. Med. 17, 218 - 222. https://doi.org/10.1111/j.1939-1676.2003.tb02437.x

Fombelle A., Varloud M., Goachet A.G., Jacotot E., Philippeau C., Drogoul C., Julliand V., 2003. Characterization of the microbial and biochemical profile of the different segments of the digestive tract in horses given two distinct diets. Anim. Sci. 77, 293-304. https://doi.org/10.1017/S1357729800059038

Giger-Reverdin S., Duvaux-Ponter C., Sauvant D., Martin O., Nunes do Prado I., Müller R., 2002. Intrinsic buffering capacity of feedstuffs. Anim. Feed Sci. Technol. 96, 83-102. https://doi.org/10.1016/S0377-8401(01)00330-3

Grant H.W., Palmer K.R., Kelly R.W., Wilson N.H., Misiewicz J.J., 1988. Dietary linoleic acid, gastric acid, and prostaglandin secretion. Gastroenterology 94, 955-959. https://doi.org/10.1016/00165085(88)90553-7

https://encyklopedia.pwn.pl/haslo/cywilizacyjne-choroby;3888921.html [dostęp: 23.03.2020].

Jones M.P., 2006. The role of psychosocial factors in peptic ulcer disease: beyond Helicobacter pylori and NSAIDs. J. Psychosomatic. Res. 60, 407-412. https://doi.org/10.1016/j.jpsychores.2005.08.009

Julliand S., Martina A., Julliand V., 2018a. Effect of dehydrated alfalfa on equine gastric and faecal microbial ecosystems. Livest. Sci. 215, 16-20. https://doi.org/10.1016/j.livsci.2017.05.005

Julliand S., Martina A., Julliand V., 2018b. Effect of live yeast supplementation on gastric ecosystem in horses fed a high-starch diet. Livest. Sci. 215, 25-29. https://doi.org/10.1016/j.livsci.2018.01.007

Kandale A., Meena A.K., Rao M.M., Panda P., Babu R., 2011. Marine algae: An introduction, food value and medicinal uses. J. Pharmacy Res. 4(1), 219-221.

Kaya-Karasu G., Huntington P.J., Iben C., Onmaz A.C., 2016. Poor performance associated with equine gastric ulcer in an Arabian racehorse. J. Faculty Vet. Med. 13(2), 187-192. https://doi.org/10.2746/095777308X282363

Kobayashi K., Arakawa T., 1995. Arachidonic acid cascade and gastric mucosal injury, protection, and healing: topics of this decade. J. Clin. Gastroenterol. 21, 12-17.

Lorenzo-Figueras M., Merritt A.M., 2002. Effects of exercise on gastric volume and $\mathrm{pH}$ in the proximal portion of the stomach of horses. Am. J. Vet. Res. 63, 1481-1487. https://doi.org/10.2460/ajvr.2002.63.1481

Luthersson N., Nielsen K., Harris P., Parkin T.D.H., 2009. Risk factors associated with equine gastric ulceration syndrome (EGUS) in 201 horses in Denmark. Equine Vet. J. 41(7), 625-630. https://doi.org/10.2746/042516409X441929 
Martínez J., Zuluaga A.M., Silveira G.E., 2016. Effects of corn oil on the gastric mucosa of horses with induced ulcer. Rev. Colomb. Cienc. Pecu. 29, 138-148. https://doi.org/10.17533/ udea.rccp.v29n2a07

Meirelles Filho J.S., Andre E.A., 2000. Gastrites. In: Endoscopia digestive. Sociedade brasileira de endoscopia digestive. MEDSI, Rio de Janeiro, pp. 713.

Moir T., O'Brien J., Hill S.R., Waldron L.A., 2016. The influence of feeding a high calcium, algae supplement on gastric ulceration in adult horses. J. Appl. Ani. Nutr. 4, e8, 1-3. https://doi.org/10.1017/jan.2016.7

Murray M.J., 1991. The pathogenesis and prevalence of gastric ulceration in foals and horses. Vet. Med. 86(8), 815-819.

Murray M.J., Schusser G.F., 1993. Measurement of 24-hr gastric pH using an indwelling pH electrode in horses unfed, fed, and treated with rantidine. Equine Vet. J. 25, 417-421. https://doi.org/10.1111/j.2042-3306.1993.tb02983.x

Murray M.J., Schusser G.F., Pipers F.S., Gross S.J., 1996. Factors associated with gastric lesions in Thoroughbred racehorses. Equine Vet. J. 28, 368-374. https://doi.org/10.1111/j.20423306.1996.tb03107.x

Prinsloo M., Hynd P., Franklin S., Weaver S., Boom R., 2019. Hair cortisol concentration is inversely related to the severity of equine squamous gastric disease. Vet. J. 249, 58-59. https://doi.org/10.1016/j.tvj1.2019.05.009

Przespolewska H., Kobryń H., Szara T., Bartyzel B.J., 2014. Podstawy anatomii zwierząt domowych. Wieś Jutra, Warszawa.

Ribeiro G., Silva L.C.L.C., Belli C.B., Vargas L.P., Piffer M.L.T., Mirian M., Souza V.A.F., Fernandes W.R., 2016. Occurrence of gastric ulcers in horses exercised on a treadmill. Ciênc. Rural 46(5), 909-914. https://doi.org/10.1590/0103-8478cr20150856

Ribeiro G., Belli C.B., Machado T.S.L., Souza V.A.F., Silva L.C.L.C., 2019. Occurrence of gastric ulcers and serum gastrin levels in jumping horses. Arq. Bras. Med. Vet. Zootec. 71(2), 357-362. https://doi.org/10.1590/1678-4162-10424

Sammon A.M., Iputo J.E., 2006. Maize meal predisposes to endemic squamous cancer of the oesophagus in Africa: breakdown of esterified linoleic acid to the free form in stored meal leads to increased intragastric PGE2 production and low-acid reflux. Med. Hypoth. 67, 1430-1435. https://doi.org/10.1016/j.mehy.2006.05.037

Scheidegger M.D., Gerber V., Bruckmaier R.M., Van der Kolk J.H., Burger D., Ramseyer A., 2017. Increased adrenocortical response to adrenocorticotropic hormone (ACTH) in sport horses with equine glandular gastric disease (EGGD). Vet. J. 228, 7-12. https://doi.org/10.1016/j.tvj1.2017.09.002

Smyth G.B., Young D.W., Schumacher J., 1989. Postprandial serum gastrin concentration in normal foals. Equine Vet. J. 21, 285-287. https://doi.org/10.1111/j.2042-3306.1989.tb02169.x

Sykes B.W., Hewetson M., Hepburn R.J., Luthersson N., Tamzali Y., 2015. European college of equine internal medicine consensus statement-equine gastric ulcer syndrome in adult horses J. Vet. Inter. Med. 29(5), 1288-1299. https://doi.org/10.1111/jvim.13578 
Elżbieta Olszewska ${ }^{1}$, Zbigniew Bełkot $^{2}$, Leszek Guz ${ }^{3}$

\title{
Nowotwory komórek barwnikowych u bojowników syjamskich (Betta splendens)
}

\author{
Neoplasia of melanophores in Siamese fighting (Betta splendens)
}

\begin{abstract}
Wstęp
Bojownik syjamski (Betta splendens) jest gatunkiem azjatyckim ryb zamieszkujących głównie dorzecza rzeki Mekong i Menam, a także stojące i wolno płynące wody całej Azji Południowo-Wschodniej [Tan i Ng 2005]. Ryby te zostały introdukowane na tereny obu Ameryk - w okolice Florydy, Brazylii i Kolumbii. Amatorsko w akwarystyce występują wśród hodowców na całym świecie.

Bojowniki syjamskie należą do ryb z rzędu okoniokształtnych (Perciformes), podrzędu błędnikowców (Anabantoidei), czyli ryb posiadających specjalny narząd, tzw. labirynt, który umożliwia im oddychanie powietrzem atmosferycznym, pobieranym znad tafli wody. Narząd ten wykształca się już u około trzytygodniowego narybku, umożliwiając oprócz oddychania skrzelowego również pobieranie tlenu $\mathrm{z}$ atmosfery.

Kolejną charakterystyczną cechą tych ryb jest agresja wobec własnego, jak też obcych gatunków, pojawiająca się u obojga płci, związana z dużą terytorialnością, co znalazło odzwierciedlenie w nazwie gatunkowej tych ryb [Braddock i Braddock 1955, Brownell 2014]. Ze względu na wymienione cechy ryby te utrzymuje się najczęściej w monogatunkowych akwariach. Różnorodność form oraz cech fenotypowych występująca u bojowników syjamskich (ryc. 1-11) skłania hodowców do intensywnej selekcji osobniczej, która ma na celu ich uwydatnienie.

Bojowniki syjamskie są to ryby o niewielkich potrzebach życiowych, względnie odporne na warunki środowiskowe oraz błędy akwarystów [Grizzle i Goodwin 2010]. Jednak pomimo swojej odporności i dużej tolerancji na parametry fizyko-chemiczne wody są podatne na choroby nowotworowe. Specyfika

\footnotetext{
${ }^{1}$ Uniwersytet Przyrodniczy w Lublinie, Wydział Medycyny Weterynaryjnej, Studenckie Koło Naukowe Zwierząt Łownych i Wolno Żyjących

${ }^{2}$ Uniwersytet Przyrodniczy w Lublinie, Wydział Medycyny Weterynaryjnej, Katedra Higieny Żywności Zwierzęcego Pochodzenia

${ }^{3}$ Uniwersytet Przyrodniczy w Lublinie, Wydział Medycyny Weterynaryjnej, Zakład Chorób Ryb i Biologii

4elaolszewska7@o2.pl
} 
chowu, dobór par do hodowli, kojarzenia krewniacze, hybrydyzacja oraz stosowanie środków chemicznych w hodowli i transporcie predysponują bojowniki syjamskie do występowania nowotworów. Szczególną grupę stanowią nowotwory komórek barwnikowych, tj. 1) melanofory zawierające melaninę - nadają barwę czarną i brązową, 2) ksantofory zawierające ksantofil - nadają żółty kolor, 3) erytrofory zawierające karotenoidy - nadają kolor pomarańczowy i czerwony, 4) leukofory zawierające guaninę lub purynę - nadają biały kolor i 5) irydofory zawierające guaninę [Paterson 2006].

Temat chorób nowotworowych ryb jest istotny, ponieważ schorzenia te mogą być modelem badawczym, dzięki któremu zwiększy się nasza wiedza ogólna dotycząca powstawania nowotworów [Grizzly i Goodwin 2010].

\section{Niewłaściwa hodowla jako przyczyna choroby}

Początki hodowli bojowników syjamskich wywodzą się z Tajlandii. W rejonie tym bojowniki hodowane są od stuleci jako popularne zwierzęta domowe i otaczane są osobliwą czcią. Z kraju tego pochodzi również najwięcej osobników znajdujących się w obiegu handlowym. Ryby utrzymywane są w hodowli w niewielkich zbiornikach, często niedostosowanych do ich potrzeb i rozmiarów. Popularne jest przeświadczenie, że ryby te nie potrzebują dużych akwariów, pogląd ten poparty jest obserwacją z natury, gdzie zdarza się, że bojownik znajdujący się w bardzo małym zbiorniku wody, np. w kałuży, jest w stanie przeżyć przez krótki okres, jednak jest to sytuacja ekstremalna.

Hodowcy, wykorzystując małe zapotrzebowanie przestrzenne tych ryb, prowadzą często tzw. hodowlę butelkową, polegającą na utrzymywaniu pojedynczych ryb w okresie wzrostu w butelkach o pojemności ok. 0,5 1, natomiast pary rozpłodowe łączone są $\mathrm{w}$ niewielkich pojemnikach. Przeciwstawną praktyką hodowlaną jest tworzenie dużych skupisk ryb, np. w oczkach wodnych lub beczkach, pozwalając na dowolne kojarzenie się wielu różnych osobników. Częstą praktyką hodowlaną jest też dodawanie do wody antybiotyków i innych związków, które ograniczają rozwój drobnoustrojów chorobotwórczych oraz zmniejszają agresję ryb, dzięki czemu mechaniczne ich uszkadzanie w czasie tarła lub transportu jest mniejsze. Czynności takie mogą powodować rozwój oporności bakterii chorobotwórczych dla ryb na powszechnie stosowane chemoterapeutyki. Hodowla bojowników prowadzona jest w celu otrzymywania osobników o wybranych cechach fenotypowych, których różnorodność jest bardzo duża. Na rycinach 1-11 przedstawiono poszczególne odmiany tego gatunku, według Brammah [2015], z charakterystycznymi cechami różnicującymi. 


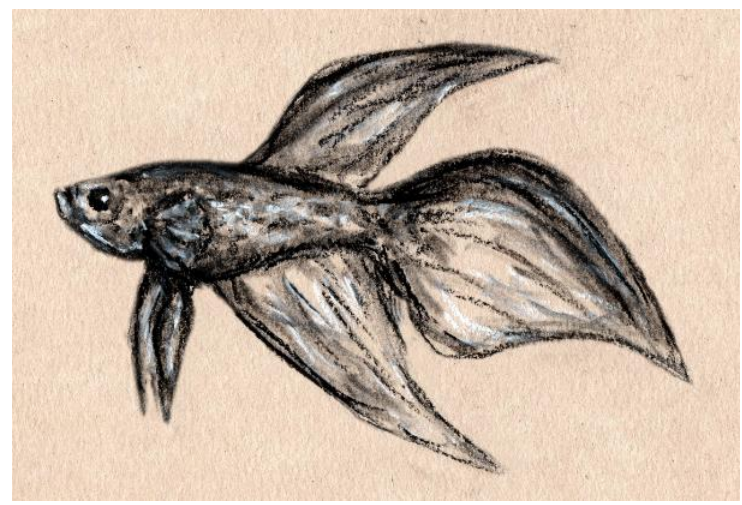

Ryc. 1. Odmiana weloniasta - Veiltail (rys. E. Olszewska)

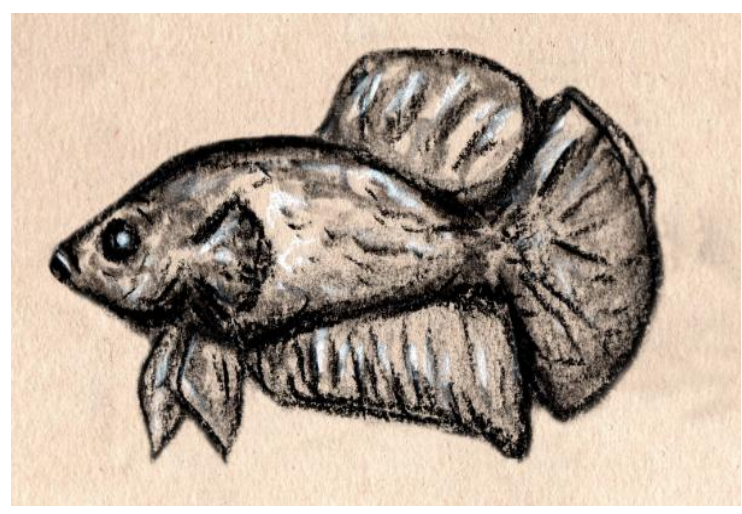

Ryc. 2. Odmiana Plakat (rys. E. Olszewska)

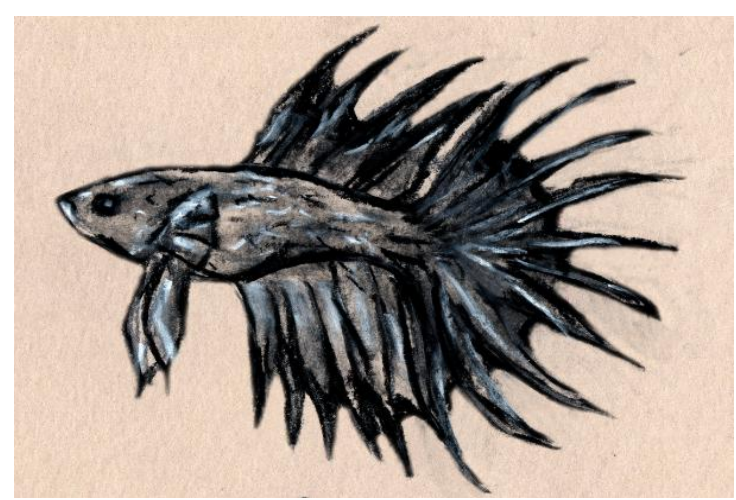

Ryc. 3. Odmiana Crowntail (rys. E. Olszewska) 


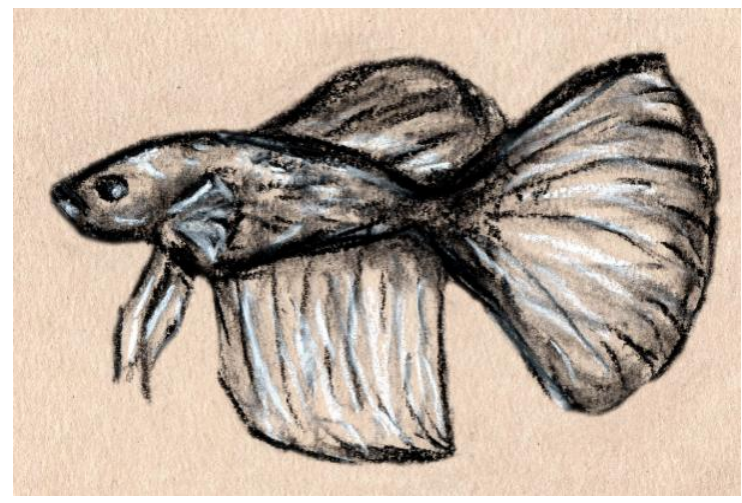

Ryc. 4. Odmiana Deltatail (rys. E. Olszewska)

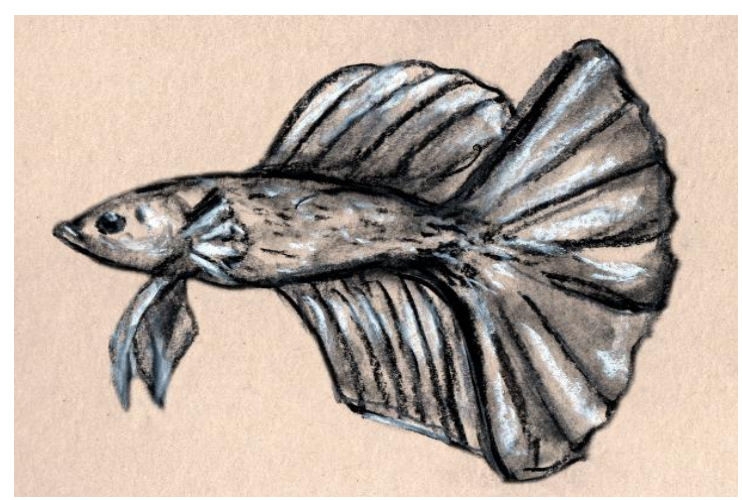

Ryc. 5. Odmiana Superdelta (rys. E. Olszewska)

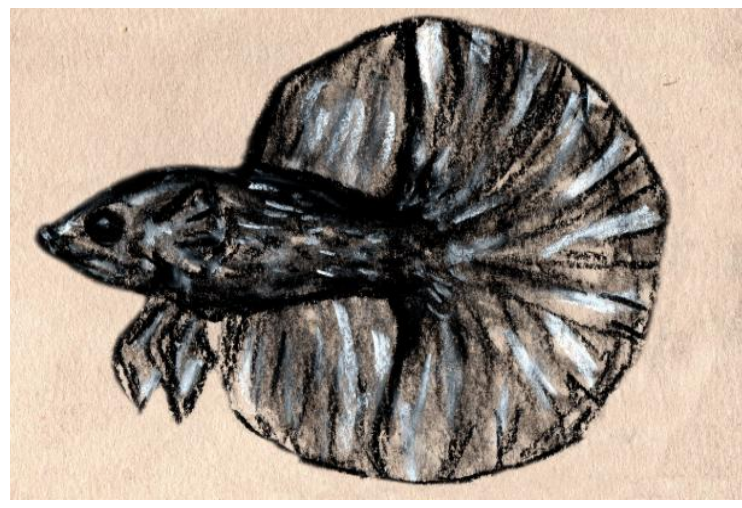

Ryc. 6. Odmiana Halfmoon (rys. E. Olszewska) 


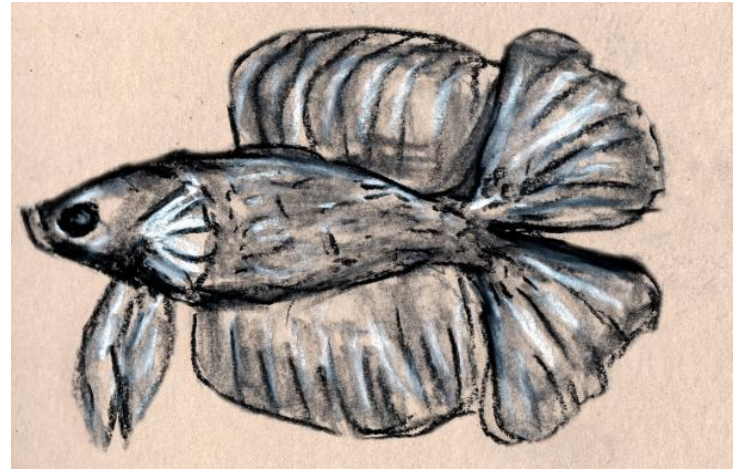

Ryc. 7. Odmiana Doublehalfmoon (rys. E. Olszewska)

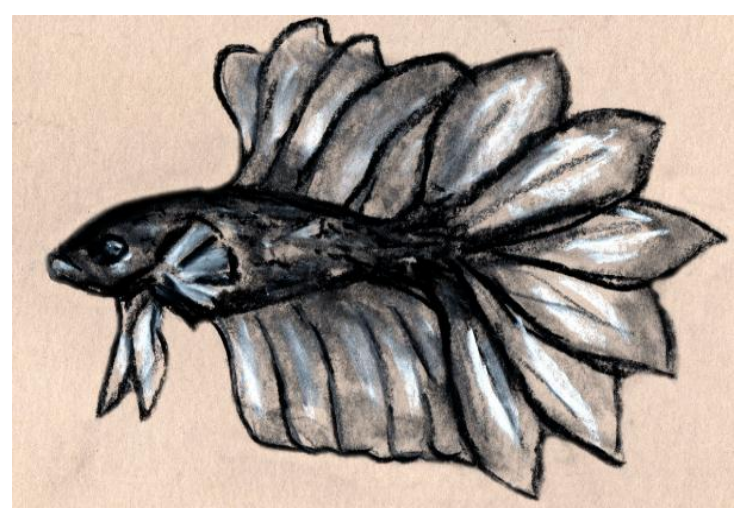

Ryc. 8. Odmiana Rosetail (rys. E. Olszewska)

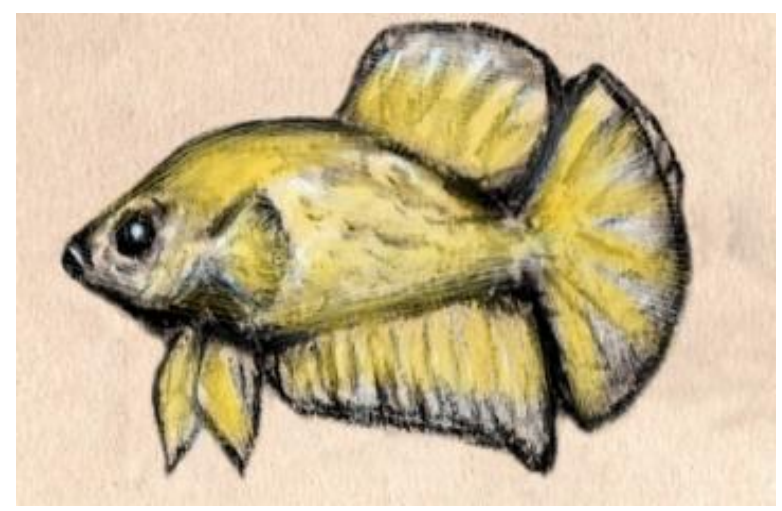

Ryc. 9. Odmiana Pineapple (rys. E. Olszewska) 


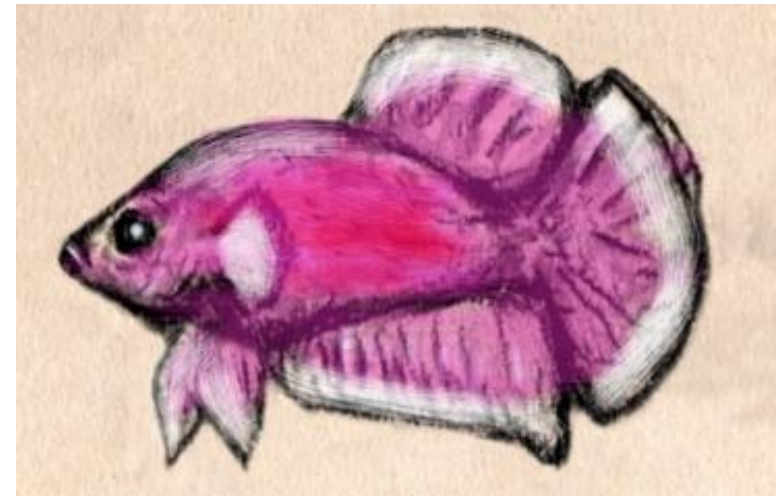

Ryc. 10. Odmiana Salamander (rys. E. Olszewska)

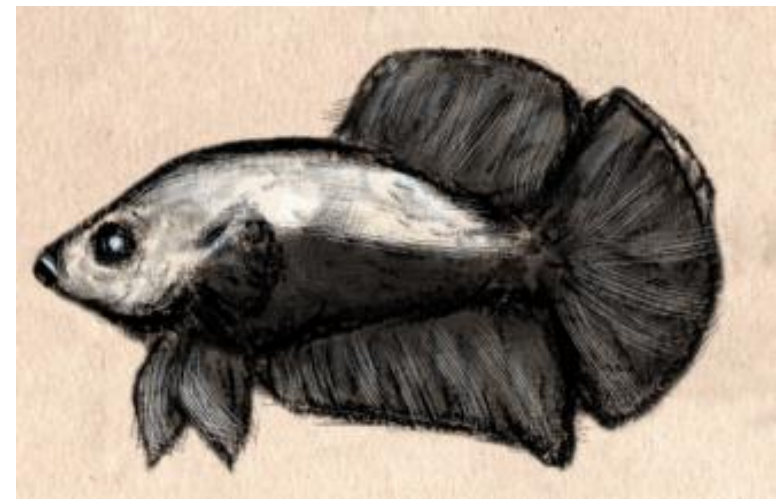

Ryc. 11. Odmiana Samuraj (rys. E. Olszewska)

Kolejnym istotnym elementem hodowli bojowników syjamskich jest ich krzyżowanie z innymi pokrewnymi gatunkami. Osobniki dziś spotykane na rynku są w większości wynikiem krzyżowania różnych gatunków, takich jak: bojownik syjamski (Betta splendens), bojownik bezbronny (Betta imbellis), bojownik szmaragdowy (Betta saraginia) oraz Betta mahachaiensis. Dzięki tworzeniu mieszańców różnogatunkowych uzyskuje się wiele odmian hodowlanych. W hodowli bojowników stosuje się również inbreeding, czyli chów wsobny. Hodowcy, poszukując osobników o określonych cechach, krzyżują ryby blisko spokrewnione ze sobą, posiadające fenotyp, który hodowca chce utrwalić. Takie praktyki zwiększają jednak możliwość powstania mutacji, które mogą predysponować te ryby do rozwinięcia się u nich choroby nowotworowej [Meuten 2017]. 


\section{Postacie choroby}

Praktyki prowadzone w nowoczesnej hodowli bojowników syjamskich sprzyjają osłabieniu ich odporności, skracają czas życia pojedynczych osobników i wpływają na powszechność występowania chorób, w tym nowotworów (ryc. 12).

Opisano wiele przykładów występowania nowotworów u tego gatunku ryb [Lombardini i in. 2010, Rahmati-Holasoo i in. 2014, Dong i in. 2018]. W zależności od umiejscowienia i charakterystyki guza opisano różne nowotwory u bojowników syjamskich.

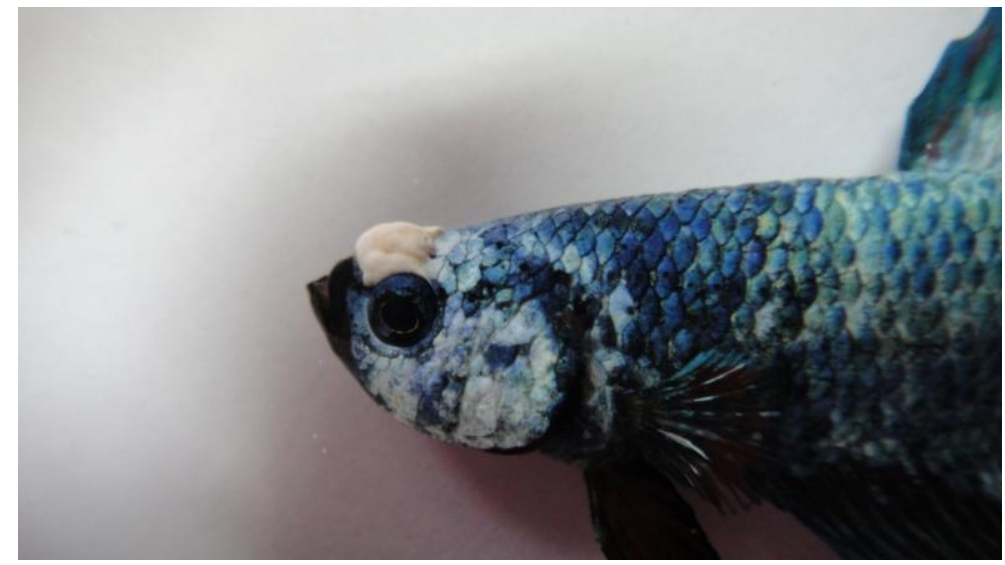

Ryc. 12. Samiec bojownika syjamskiego ze zmianą w okolicy głowy (fot. L. Guz)

Jedną z opisanych przez Donga i in. [2018] form choroby nowotworowej u bojowników syjamskich jest skin nodule syndrome (SNS) - zespół guzka skóry. W badaniu histopatologicznym potwierdzono uszkodzenia tkanek na zewnątrz i wewnątrz ciała ryb, w naskórku, skórze właściwej i tkance łącznej. Zmiany doprowadziły do rozszczepienia i atrofii mięśni. Zmiany nowotworowe zaobserwowano również w wątrobie, nerkach, śledzionie i jelitach. Obraz mikroskopowy wykazał ciemnobrązowe obszary i zmiany martwicze. Istotne jest, że w przebiegu choroby nie zaobserwowano żadnych oznak infekcji wirusowej, pasożytniczej lub wielokomórkowej.

Temat nowotworów komórek barwnikowych został przedstawiony również w pracy Rahmati-Holasoo i in. [2014]. Autorzy opisują przypadek ryby z wyraźnym guzem na płetwie odbytowej. Badanie mikroskopowe wykazało, że masa guza złożona była głównie $\mathrm{z}$ adipocytów. Komórki te były okrągłe, miały różną wielkość, a ich jądra były zepchnięte na brzeg komórki. Zmiany nowotworowe były dobrze unaczynione. Na podstawie wyników badań histologicznych obserwowane zmiany opisano jako naczyniakomięśniakotłuszczaka (angiomyolipoma). Przeprowadzone barwienie Massona-Fontany oraz immunohistochemiczne Melan A wykazały pozytywną reakcję melanoforów, co pozwoliło po- 
twierdzić, że są to zmiany nowotworowe. Na podstawie schematu klasyfikacji Gimenez-Conti i in. [2001] przypadek prezentowany w pracy Rahmati-Holasoo $\mathrm{i}$ in. [2014] został zaklasyfikowany jako czerniak typu nabłonkowego.

Kwestie etnologiczne czerniaków u ryb poruszają również Masahito i in. [1989]. Powołują się na badania, które przeprowadzili Reed i Gordon [1931], ukazujące silny wpływ genetyki na potencjał występowania tych nowotworów. Gen odpowiadający za syntezę komórek barwnikowych znajduje się na chromosomie X i jego aktywność ograniczana jest grupą genów modyfikujących. Na podstawie serii badań polegających na wielokrotnym krzyżowaniu mieczyka Hellera (Xiphophorus hellerii) z hybrydą mieczyka Hellera (Xiphophorus hellerii) i ryb z rodzaju Xiphophorus stwierdzono sukcesywnie zmniejszającą się liczbę genów modyfikujących, co pozwoliło na nieograniczoną proliferację melanocytów. Ryby dotknięte tym schorzeniem były słabsze, wolniejsze, mniej żywotne i charakteryzowały się wysoką i wczesną śmiertelnością. Kolejnym ważnym problemem w diagnostyce choroby i selekcji osobniczej jest fakt, że objawy zewnętrze u ryb mogą pojawiać się późno, najczęściej ok. 6. miesiąca życia, czyli w wieku pierwszego tarła. W artykule Rahmati-Holasoo i in. [2014] autorzy powołują się na przykład 2-letniego bojownika syjamskiego, u którego guz pojawił się w 21. miesiącu życia.

W pracy Lombardiniego i in. [2010] przedstawione zostały dwa opisy bojowników syjamskich chorych na nefroblastomę. W obu przypadkach zmiany obejmowały $90 \%$ nerek, a obraz histopatologiczny ukazywał charakterystyczne w przypadku nowotworów gniazda komórkowe. Przedstawione przez Lombardiniego i in. [2010] przypadki są pierwszymi doniesieniami o występowaniu tego rodzaju guza u bojowników syjamskich.

\section{Obserwacje wlasne i wnioski}

Obserwacje własne potwierdziły dziedziczenie cech nowotworzenia komórek barwnikowych u potomstwa. W roku 2018, w amatorskiej hodowli autorki niniejszej pracy (Elżbiety Olszewskiej), doszło do 7 udanych kojarzeń, w których przynajmniej połowa narybku osiągnęła dojrzałość do rozrodu. Wszystkie ryby w każdej parze były zdrowe i wyselekcjonowane zgodnie z przewidywanymi cechami u potomstwa. Jeden z samców użyty do rozrodu okazał się jednak chory na chorobę nowotworową (guz pojawił się w 4. miesiącu po tarle) - ryc. 13.

W jego potomstwie u 6 z 70 osobników w wieku dojrzałym pojawiły się objawy nowotworzenia. W potomstwie wszystkich pozostałych par, złożonym z 350 ryb, które uzyskały wiek dojrzały, na chorobę nowotworową zachorowało tylko 10 osobników. $Z$ obserwacji wynika, że prawdopodobieństwo wystąpienia nowotworów u potomstwa ryb chorych jest trzykrotnie wyższa niż u potomstwa ryb zdrowych. 


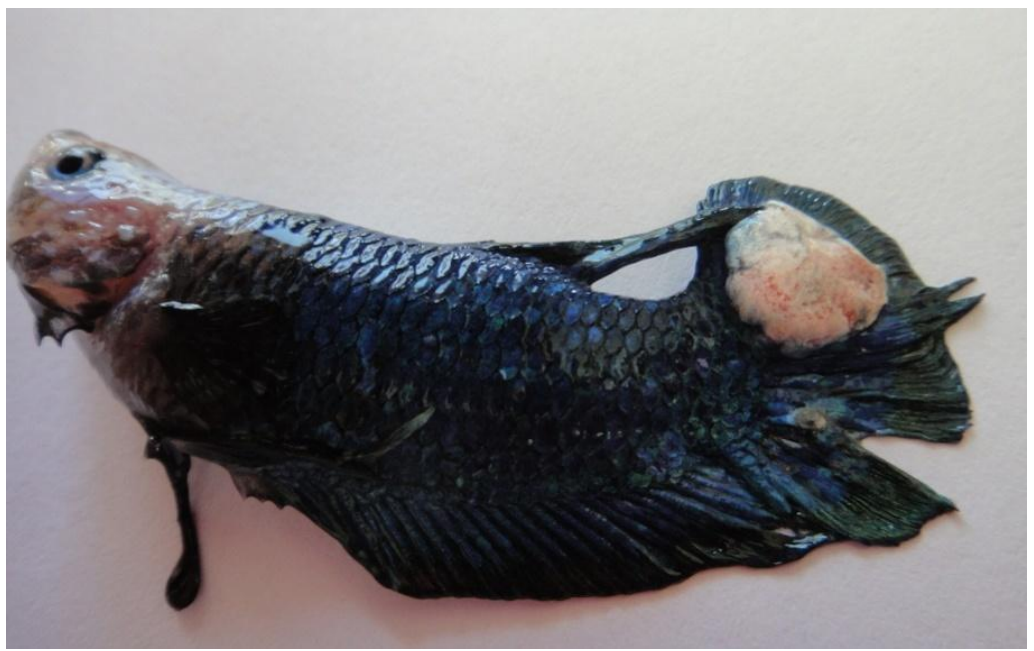

Ryc. 13. Samiec bojownika syjamskiego ze zmianą w okolicy płetwy ogonowej (fot. L. Guz)

Kolejna obserwacja potwierdza, że częstość występowania nowotworów jest tym wyższa, im dalsze od pierwowzoru gatunku są odmiany rodziców oraz im bardziej sterylne są warunki utrzymania ryb.

Obserwacje własne i autorów cytowanych publikacji wskazują na konieczność eliminowania z hodowli osobników o tendencji do występowania nowotworów komórek barwnikowych oraz zachowania odpowiednich warunków hodowlanych specyficznych dla tych ryb. Diagnostyka i leczenie chorób nowotworowych u ryb akwariowych sprawiają pewne trudności. Wiążą się one z wysokimi kosztami badań diagnostycznych i leków, które mogą okazać się nieskuteczne. Dodatkowym problemem w diagnostyce tych nowotworów jest również nierozważne podejście właścicieli zwierząt, które często są nieleczone i wymieniane na inne, zdrowsze, ładniejsze.

\section{Bibliografia}

Braddock J.C., Braddock Z.I., 1955. Aggressive behavior among females of the Siamese fighting fish, Betta splendens. Physiol. Zool. 28(2), 152-172.

Brammah M., 2015. The Betta Bible. Martin Brammah, UK.

Brownell A., 2014. A Study of female courtship behavior and mating preferences in Bettasplendens. Lake Forest College, Lake Forest.

Dong H.T., Senapin S., Phiwsaiy K., Techatanakitarnan C., Dokladda K., Ruenwongsa, P., Panijpan B., 2018. Histopathology and culturable bacteria associated with „big belly” and „skin nodule” syndromes in ornamental Siamese fighting fish, Bettas splendens. Microb. Pathog. 122, 46-52. https://doi.org/10.1016/j.micpath.2018.06.005

Gimenez-Conti I., Woodhead A., Harshbarger J.C., Kazianis S., Setlow R.B., Nairn R.S., Walter R.B., 2001. A proposed classification scheme for Xiphophorus melanomas based on 
histopathological analyses. Mar. Biotechnol. 3, 100-106. https://doi.org/10.1007/s101260010031-4

Grizzle J.M., Goodwin A.E., 2010. Neoplasms and related disordes. Fish Diseases and Disorders 2, 19-84. https://doi.org/10.1016/j.cvex.2004.04.012

Lombardini E.D., Law M., Lewis B.S., 2010. Nephroblastoma in two Siamese fighting fish Betta Splendens. Fish Pathol. 45(3), 137-139. https://doi.org/10.3147/jsfp.45.137

Masahito P., Ishikawa T., Sugano H., 1989. Pigment cells and pigment cell tumors in fish. J. Investig. Dermatol. 92(5), 266-270. https://doi.org/10.1038/jid.1989.79

Meuten D.J., 2017. Tumors in domestic animals. John Wiley \& Sons, Ames. https://doi.org/10.1002/9781119181200

Paterson S., 2006. Skin diseases of exotic pets. Blackwell Science Ltd., Oxford-Ames-Iowa.

Rahmati-Holasoo H., Alishahi M., Shokrpoor S., Jangarannejad A., Mohammadian B., 2014. Invasion of melanoma to angiolipoma in a male Siamese fighting fish, Bettasplendens. Regan. J. Fis. Dis. 38, 925-930. https://doi.org/10.1111/jfd.12301

Reed H.D., Gordon M., 1931. The morphology of melanoticover-growths in hybrids of Mexican killifishes. J. Natl. Cancer Inst. 16, 1524-1546.

Tan H.H., Ng. P.K.L., 2005. The Fighting Fishes (Teleostei: Osphronemidae: Genus Betta) of Singapore, Malaysiaand Brunei. Raffles B. Zool. 13, 43-99. 


\title{
Adrian Pluta ${ }^{1,3}$, Kinga Smater ${ }^{1}$, Damian Spustek ${ }^{1}$, Kamil Drabik ${ }^{2}$, Iwona Rozempolska-Rucińska ${ }^{2}$ Justyna Batkowska ${ }^{2}$
}

\section{Struktura społeczna w stadzie kur nieśnych i jej wpływ na behawior i fizjologię ptaków}

Social structure in the laying hen stock and its influence on birds' behaviour and physiology

\begin{abstract}
Wstęp
Kura domowa, będąca jednym z najbardziej popularnych gatunków wśród drobiu, charakteryzuje się szeregiem różnorodnych zachowań. Ptaki te bardzo szybko ustalają hierarchię w stadzie, czemu towarzyszy pasmo różnych sygnałów oraz zachowań. Kury, które mają wyższy status w stadzie, dominują na terytoriach bardziej obfitych w pożywienie, a także wybierają najlepsze miejsca na wybiegu oraz w kurniku. W typowym stadzie przewodzi kogut, a jego pozycja jest przez kury respektowana. W stadzie utrzymywanym bez koguta hierarchia jest zaburzona i stadu przewodzi kura, która ma cechy samcze. Może to być powodowane podwyższonym poziomem testosteronu, na który wpływają m.in. czynniki społeczne i środowiskowe [Müller i in. 2002].
\end{abstract}

\section{Hierarchia stada}

Proste reakcje behawioralne przyporządkować można do dwóch grup: związanej z pobieraniem pokarmu (odruch dziobania, drapanie, instynkt żerowania) oraz z pielęgnacją (czyszczenie piór, kąpiele piaskowe i słoneczne). Wzajemne dziobanie w stadzie kur występuje głównie w momencie tworzenia struktury, która ma charakter hierarchii liniowej. Zachowanie przejawiane w tym momencie określane jest jako tzw. piramida dziobania. Kury naturalnie żyją w grupach, w których kogut dominuje nad kurami na określonym terytorium [Queiroz i Cromberg 2006]. Każdy z członków grupy ma swoje określone miejsce w hierarchii. Zabranie bądź dodanie nowego osobnika powoduje zaburzenie tej struk-

\footnotetext{
1 Uniwersytet Przyrodniczy w Lublinie, Studenckie Koło Naukowe Biologii, Hodowli i Użytkowania Drobiu (Studenckie Koło Naukowe działa pod patronatem Krajowej Rady Drobiarstwa)

${ }^{2}$ Uniwersytet Przyrodniczy w Lublinie, Instytut Biologicznych Podstaw Produkcji Zwierzęcej

3 adrian_pluta@yahoo.com
} 
tury, która musi się na nowo utworzyć. Ustanowienie hierarchii w stadzie odbywa się poprzez dziobanie, stąd nazwa zjawiska.

Jak podaje Loiselet [2004], agresja jest zrytualizowaną formą komunikacji zwierząt, która ma na celu ustalenie oraz utrzymanie hierarchii w stadzie. U kur system hierarchiczny jest stosunkowo wyraźny. Kury postawione wyżej w hierarchii często dziobią ptaki znajdujące się na niższych szczeblach piramidy. Dziobanie ma na celu ustanowienie oraz utrzymanie dominacji w stadzie [Savory 1995]. Takie zachowanie może być także częściowo wywołane zaburzeniami społecznymi. Dziobanie często skierowane jest na głowę, lecz gdy jest ona niedostępna dla dziobiącego zwierzęcia, zachowanie to przekierowane zostaje na inne części ciała. Wykonane jest ono ze znaczną siłą. Podczas takiego procesu atakowany osobnik może wokalizować $\mathrm{z}$ bólu.

Agresja bądź jej zapowiedź są powszechnie stosowane w stadzie i mają na celu wykluczenie osobników z osobistej przestrzeni zwierzęcia. McBride i in. [1963] wykazali, że przestrzeń osobista nie rozciąga się jednakowo we wszystkich kierunkach. Była ona większa przed kurczętami, a większość ich ruchów miała na celu uniknięcie przestrzeni osobistych dominujących kur. Ataki lub groźne zachowania były często kończone przez podporządkowanego osobnika poprzez ucieczkę do granicy przestrzeni osobistej dominującego zwierzęcia [Queiroz i Cromberg 2006]. Wiele gatunków zwierząt, w tym także drób hodowlany, pozwala pozostać w grupie ptakom, które są niżej w hierarchii, dopóki będą one prezentować zachowania podporządkowania. Ptaki te mogą jednak ulec zranieniu, wydaleniu ze stada lub zostać zabite w czasie walki [Price 2002].

Hierarchiczny system w stadzie jest rygorystycznie utrzymywany poprzez zachowania agresywne, lecz po ustaleniu hierarchii poziom agresji maleje i zastępuje go demonstracja dominacji. Koguty i kury tworzą odrębne hierarchie społeczne. Dominacja samców nad samicami rzadko jest kwestionowana, dlatego agresywne zachowanie samców wobec kur jest rzadko spotykane w naturalnych warunkach [Milman i Duncan 2000]. Natomiast agresja między samcami nasila się podczas sezonu rozrodczego, ze względu na wzrost poziomu testosteronu [Ros i in. 2002] oraz rywalizację o możliwość krycia. Ptaki postawione wyżej w hierarchii dominują w miejscach o lepszych zasobach, np. z większą ilością pożywienia. Takie zachowanie wymusza na osobnikach postawionych na niższych szczeblach hierarchii żerowanie w miejscach, w których zasoby są ograniczone bądź są niższej jakości. Hierarchia w stadzie drobiu jest szczególnie widoczna przy zajmowaniu pozycji do snu. Osobniki na wyższych szczeblach hierarchii nocują bliżej koguta lub dominującej kury.

Istotnym elementem wpływającym na porządek hierarchii dziobania jest wielkość stada. W swoich badaniach Guhl [1968] wykazał, że grupa składająca się z 96 ptaków wykazywała całkowity porządek dziobania. W późniejszych badaniach, podczas których obserwacją objęto stada liczące od 100 do 400 ptaków [Craig i Guhl 1969], zauważono, że w grupach składających się z 200 osobników kury wykazywały tendencję do dłuższego przebywania na obszarach, 
na których całkowicie dominowały. Przypuszczać można, że zachowanie takie pozwala im na ograniczenie potrzeby rozpoznawania większej ilości osobników należących do stada. W wyniku tego kury przebywające w większych stadach mają skłonność do ustalania hierarchii dziobania wśród osobników znajdujących się w najbliższym sąsiedztwie, co zapobiega licznym atakom. Z kolei Banks [1956] w swoich badaniach zaobserwował, że istnieje dodatnia korelacja pomiędzy względną częstotliwością ataków, mających na celu naruszenie porządku dziobania, a wielkością stada. Ataki te polegały na wykazywaniu agresji w stosunku do osobnika znajdującego się na wyższym szczeblu w hierarchii. Były one jednak bezskuteczne, bowiem w ich wyniku nie dochodziło do odwrócenia stopnia dominacji.

\section{Wpływ hierarchii na tworzenie się cech fizycznych (cechy płciowe)}

Najbardziej odpowiednimi systemami utrzymania drobiu pod względem zapewnienia naturalnego wzorca behawioralnego są systemy wybiegowe. Stworzenie stada bez koguta może skutkować pojawieniem się u samic trzeciorzędowych cech samczych, tzn. będą miały dłuższe dzwonki i grzebień oraz pióra ogona. Dodatkowo obserwowano zachowania samcze, jak próby krycia czy przewodzenie stadu. U osobników, które posiadają wyżej wymienione cechy samcze, odnotowuje się podwyższony poziom testosteronu we krwi [Williams i McGibbon 1956].

Testosteron, będący męskim hormonem płciowym, jest podstawowym androgenem z grupy hormonów steroidowych, które rozwijają i utrzymują cechy męskie. Jest on w znacznych ilościach produkowany przez komórki Leydiga znajdujące się w jądrach, w mniejszym stopniu wytwarzany jest także w korze nadnerczy $\mathrm{i}$ jajniku samic [Mazur i Booth 1998]. U kogutów wskaźnikiem aktywności androgenów jest grzebień [Gryzińska i in. 2011]. Hormony płciowe, które produkowane są przez gonady męskie (jądra) i żeńskie (jajniki), odpowiadają za rozwój cech płciowych u kur. Odpowiada za to także wewnętrzna tożsamość płciowa komórek ciała. Jak podaje Lambeth i in. [2016], działanie testosteronu doprowadza do różnicowania płciowego, tzn. do rozwoju ostróg na skoku samca, a także dzwonków i grzebienia na jego głowie. Valdez i in. [2010] donoszą, że zabieg polegający na usunięciu jajników u kur różnych ras powoduje u nich wzrost ostróg do rozmiarów charakterystycznych dla samców. Dlatego badacze ci przypuszczają, że estrogeny, które produkowane są przez jajniki, powodują zahamowanie tworzenia się ostróg u kur. Upierzenie u kogutów jest kolejną cechą płciową. Owens i Short [1995] uważają, że u ptaków grzebiących upierzenie samicy determinowane jest przez estrogeny, natomiast u samca rozwija się ono przy ich braku.

Collias [1943] zauważył, że czasami kurze udaje się rozstrzygać relacje hierarchiczne bez jawnej agresji. Wood-Gush [1971] zasugerował, że poszczególne osobniki mogą unikać konfliktu fizycznego, obserwując wygląd i zachowania behawioralne innych członków stada. Mogą także oceniać zdolność konkurencyjną 
poszczególnych cech. Próbowano powiązać czynniki fizyczne, takie jak masa ciała czy cechy grzebienia, z interpretacją wyniku interakcji agonistycznych [O'Connor $i$ in. 2011]. Testosteron w połączeniu $z$ estrogenem przyczynia się do zatrzymywania wapnia w kościach, co zwiększa ich masę. Może to oznaczać, że kura, która ma wyższy poziom testosteronu we krwi, ma znacznie większą masę ciała, czego skutkiem jest znalezienie się jej na wyższym szczeblu hierarchicznym. Jednakże Forkman i Haskell [2004] oraz Martin i in. [1997] sugerują, że masa ciała poszczególnych osobników nie wpływa na pozycję w stadzie.

O'Connor i in. [2011] wykazali dodatnią korelację pomiędzy wielkością grzebienia kur a ich umiejętnościami konkurencyjnymi. David's score (ranking dominacji) jest metodą służącą do obliczania stopnia dominacji dla osobników $\mathrm{w}$ danej grupie społecznej, w oparciu o wyniki ich agonistycznej interakcji z innymi członkami stada oraz przy uwzględnieniu siły ich przeciwników [Gammell i in. 2003]. Kury, które otrzymały wyższe wyniki w David's score, miały większy $\mathrm{i}$ bardziej obszerny grzebień niż te z niższymi wynikami. Badacze zwrócili uwagę na fakt, iż istotna była także barwa grzebieni, która mierzona długością fali zmieniała się od 603 do $616 \mathrm{~nm}$. Kury, u których ten kolor był żółtawoczerwony, a nie czysto czerwony, zwykle miały wyższe zdolności konkurencyjne [O'Connor i in. 2011]. Kolor grzebienia jest kontrolowany poprzez ukrwienie, co sugeruje, że różnice odzwierciedlają zmienność w osoczu krwi składników, takich jak karotenoidy. Mougeot i in. [2007] wykazali, że zaczerwienienie grzebienia u cietrzewia związane jest z karotenoidami, wysokim stężeniem testosteronu oraz ogólną kondycją ciała.

Co ciekawe, z jaj zniesionych przez kury dominujące częściej wykluwały się pisklęta płci męskiej, a jaj te odznaczały się wyższym poziomem testosteronu niż jaja, z których wykluły się samice [Müller i in. 2002]. Takiej zależności nie stwierdzono jednak w przypadku matek, których status społeczny był niższy. Wyniki wskazują więc na prawdopodobieństwo wpływu androgenów na płeć piskląt, przy czym stężenie hormonów znajdujących się w jajach powiązane jest jedynie z matczyną pozycją społeczną.

Kury, które mają niższy status społeczny w stadzie, przejawiają więcej zachowań świadczących o wysokim poziomie kortykosteronu (hormonu stresu). Za reakcję, która jest odpowiedzią na negatywne emocje, odpowiedzialny jest wzajemny wpływ zarówno układu immunologicznego, jak i nerwowego. Następuje wtedy aktywacja współczulnego układu nerwowego - rdzenia nadnerczy oraz układu podwzgórze-przysadka-nadnercza [Zimecki i Arytm 2004]. Zwierzęta, które są poddane dłuższemu stresowi, wykazują obniżoną odporność na infekcję. Jak podaje De Jong i in. [2001], każdej reakcji stresowej towarzyszy nadmierne wydzielanie hormonów kortykotropowych, a ich działanie supresyjne na układ odpornościowy sprawia, że zwiększa się wrażliwość organizmu na zakażenia bakteriami. Dodatkowo Kitaysky i in. [2003] oraz Sapolsky i in. [2000] wykazali, że stale podwyższony poziom hormonów stresu może wywierać negatywny wpływ na wzrost, kondycję oraz ogólny stan zdrowia u zwierząt. 
Warto zaznaczyć, iż stres nie powoduje jedynie negatywnych skutków w organizmie zwierzęcia, ale odgrywa w nim również ważną rolę. Ułatwia on dostosowanie się zwierząt do zmieniających warunków środowiskowych [Kozak i in. 2019]. Z badań, które przeprowadzili Blas i in. [2007] oraz Koch i in. [2002], wynika, że pod wpływem osi podwzgórze-przysadka-nadnercza, która reaguje na zaburzenia środowiskowe, do układu krążenia uwalniane są glukokortykoidy, które wywołują szereg zmian fizjologicznych oraz behawioralnych. Poziom kortykosteronu określić można poprzez badanie jego obecności we krwi, kale, ślinie włosach oraz piórach. Są to wiarygodne oraz obiektywne wskaźniki poziomu stresu u zwierząt [Weimer i in. 2018].

W badaniach Kozak i in. [2019] wykazano, że na rozładowanie stresu u zwierząt pozwalają zachowania związane $\mathrm{z}$ pielęgnacją, takie jak kąpiele piaskowe czy trzepotanie skrzydłami. Dzięki nim ptaki mogą również utrzymać odpowiednią higienę. Natomiast Spruijt i in. [1992] sugerują, że takie zachowania mogą mieć na celu wypieranie ograniczenia pobudzenia lub relaksacji.

Należy jednak zwrócić uwagę na fakt, iż behawioralne i endokrynologiczne reakcje wywołane stymulacjami lękowymi są jedynie wskaźnikami strachu i nie mogą być traktowane jako bezpośrednia miara subiektywnego stanu strachu [Forkman i in. 2007].

\section{Podsumowanie}

Kury postawione wyżej w hierarchii często dziobią ptaki znajdujące się na niższych szczeblach piramidy, tym samym zapewniając sobie większy dostęp do zasobów. W przypadku stad utrzymywanych bez koguta, który jako samiec zawsze zajmuje najwyższą pozycję w stadzie, u kur może nastąpić rozwój trzeciorzędowych cech męskich, a jego stopień jest dodatnio skorelowany z zajmowanym przez nie miejscem $w$ hierarchii. Kury znajdujące się na najniższej pozycji w stadzie mogą wykazywać zachowania świadczące o wysokim poziomie stresu, jednak ani behawior zwierzęcia, ani przeprowadzone u niego badania endokrynologiczne nie mogą być w pełni miarodajnymi parametrami wskazującymi na poziom strachu, należy jednak uwzględniać fakt, że reakcje behawioralne świadczące o określonych emocjach nie są wyznacznikiem poziomu stresu.

\section{Bibliografia}

Banks E.M., 1956. Social organization in red jungle fowl hens (Gallus gallus Subsp.). Ecology 37(2), 239-248. https://doi.org/10.2307/1933136

Blas J., Bortolotti G.R., Tella J.L., Baos R., Marchant T.A., 2007. Stress response during development predicts fitness in a wild, long lived vertebrate. P. Natl. Acad. Sci. USA. 104(21), 8880-8884. https://doi.org/10.1073/pnas.0700232104.

Collias N.E., 1943. Statistical analysis of factors which make for success in initial encounters between hens. Am. Nat. 77(773), 519-538. https://doi.org/10.1086/281154 
Craig J.V., Guhl A.M., 1969. Territorial behavior and social interactions of pullets kept in large flocks. Poultry Sci. 48(5), 1622-1628. https://doi.org/10.3382/ps.0481622

de Jong I.C., van Voorst A.S., Erkens J.H., Ehlhardt D.A., Blokhuis H.J., 2001. Determination of the circadian rhythm in plasma corticosterone and catecholamine concentrations in growing broiler breeders using intravenous cannulation. Physiol Behav. 74(3), 299-304. https://doi.org/10.1016/S0031-9384(01)00562-5

Forkman B., Boissy A., Meunier-Salaün M.C., Canali E., Jones R.B., 2007. A critical review of fear tests used on cattle, pigs, sheep, poultry and horses. Physiol. Behav. 92(3), 340-374. https://doi.org/10.1016/j.physbeh.2007.03.016

Forkman B., Haskell M.., 2004. The maintenance of stable dominance hierarchies and the pattern of aggression: support for the suppression hypothesis. Ethology 110(9), 737-744. https://doi.org/10.1111/j.1439-0310.2004.01009.x

Gammell M.P., Vries H.D., Jennings D.J., Carlin C.M., Hayden T.J., 2003. David's score: a more appropriate dominance ranking method than Clutton-Brock et al.'s index. Anim. Behav. 66(3), 601-605. https://doi.org/10.1006/anbe.2003.2226

Gryzińska M., Strachecka A., Krauze M., 2011. Concentration of testosterone in blood serum in roosters of the Polbar breed depending on age. Annales UMCS, Zootechnica 29(4), 4650. https://doi.org/10.2478/v10083-011-0024-3

Guhl A.M., 1968. Social behavior of the domestic fowl. Trans. Kans. Natl. Acad. Sci. USA (1903-) 71(3), 379-384. https://doi.org/10.2307/3627156

Kitaysky A.S., Kitaiskaia E.V., Piatt J.F., Wingfield J.C., 2003. Benefits and costs of increased levels of corticosterone in seabird chicks. Horm. Behav. 43(1), 140-149. https://doi.org/ 10.1016/S0018-506X(02)00030-2

Koch, K.A., Wingfield, J.C., Buntin, J.D., 2002. Glucocorticoids and parental hyperphagia in ring doves (Streptopeliarisoria). Horm. Behav. 41(1), 9-21. https://doi.org/10.1006/hbeh.2001.1726

Kozak A., Rozempolska-Rucińska I., Kasperek K., Bownik A., 2019. Level of stress in relation to emotional reactivity of hens. Ital. J. Anim. Sci. 18(1), 1252-1258. https://doi.org/ 10.1080/1828051X.2019.1642150

Lambeth L.S., Morris K., Ayers K.L., Wise T.G., O’Neil T., Wilson S., Smith C.A., 2016. Overexpression of anti-Müllerian hormone disrupts gonadal sex differentiation, blocks sex hormone synthesis, and supports cell autonomous sex development in the chicken. Endocrinology 157(3), 1258-1275. https://doi.org/10.1210/en.2015-1571

Loiselet J., 2004. Behaviour and feather pecking are priority areas for selection. World Poultry Sci. J. 20(7), 22-24

Martin F., Beaugrand J.P., Laguë P.C., 1997. The role of hen's weight and recent experience on dyadic conflict outcome. Behav. Process. 41(2), 139-150. https://doi.org/10.1016/S03766357(97)00040-5

Mazur A., Booth A., 1998. Testosterone and dominance in men. Behav. Brain Sci. 21(3), 353-363. https://doi.org/10.1017/S0140525X98001228

McBride G., James J.W., 1963. Social forces determining spacing and head orientation in a flock of domestic hens. Nature 197, 1272-1273.

Milman S.T., Duncan I.H., 2000. Strain differences in aggressiveness of male domestic fowl in response to a male model. Appl. Anim. Behav. Sci. 6, 217-233. https://doi.org/10.1016/S0168 1591(99)00082-9

Mougeot F., Pérez-Rodríguez L., Martinez-Padilla J., Leckie F., Redpath S.M., 2007. Parasites, testosterone and honest carotenoid-based signalling of health. Funct. Ecol. 21(5), 886-898 https://doi.org/10.1111/j.1365-2435.2007.01302.x

Müller W., Eising C.M., Dijkstra C., Groothuis T.G., 2002. Sex differences in yolk hormones depend on maternal social status in Leghorn chickens (Gallus gallus domesticus). P. Roy. Soc. B-Biol. Sci. 269(1506), 2249-2255.

O'Connor E.A., Saunders J.E., Grist H., McLeman M.A., Wathes C.M., Abeyesinghe S.M., 2011 The relationship between the comb and social behaviour in laying hens. Appl. Anim. Behav. Sci. 135(4), 293-299. https://doi.org/10.1016/j.applanim.2011.09.011 
Owens I.P., Short R.V., 1995. Hormonal basis of sexual dimorphism in birds: implications for new theories of sexual selection. Trends Ecol. Evol. 10(1), 44-47. https://doi.org/10.1016/S01695347(00)88967-3

Price E.O., 2002. Animal domestication and behavior. Cabi Publishing, Davis.

Queiroz S.A., Cromberg V.U., 2006. Aggressive behavior in the genus Gallus sp. Braz. J. Poultry Sci. 8(1), 1-14. https://doi.org/10.1590/S1516-635X2006000100001

Ros A.F., Dieleman S.J., Groothuis T.G., 2002. Social stimuli, testosterone, and aggression in gull chicks: support for the challenge hypothesis. Horm. Behav. 41(3), 334-342. https://doi.org/ 10.1006/hbeh.2002.1768

Sapolsky R.M., Romero L.M., Munck A.U., 2000. How do glucocorticoids influence stress responses? Integrating permissive, suppressive, stimulatory, and preparative actions. Endocr. Rev. 21(1), 55-89. https://doi.org/10.1210/edrv.21.1.0389

Savory C.J., 1995. Feather pecking and cannibalism. World Poultry Sci. J. 51(2), 215-219. https://doi.org/10.1079/WPS19950016

Spruijt B.M., Van Hooff J.A., Gispen W.H., 1992. Ethology and neurobiology of grooming behavior. Physiol. Rev. 72(3), 825-852. https://doi.org/10.1152/physrev.1992.72.3.825

Valdez Jr M.B., Mizutani M., Kinoshita K., Fujiwara A., Yazawa H., Shimada K., Yamagata T., 2010. Differential development of sex-related characters of chickens from the GSP and PNP/DO inbred lines after left ovariectomy. J. Reprod. Develop. 56(1), 154-161. https://doi.org/10.1262/jrd.09-156S

Weimer S.L., Wideman R.F., Scanes C.G., Mauromoustakos A., Christensen K.D., Vizzier-Thaxton Y., 2018. An evaluation of methods for measuring stress in broiler chickens. Poultry Sci. 97(10), 3381-3389. https://doi.org/10.3382/ps/pey204

Williams C., McGibbon W.H., 1956. An analysis of the peck-order of the female domestic fowl, Gallus domesticus. Poultry Sci. 35(5), 969-976. https://doi.org/10.3382/ps.0350969

Wood-Gush D.G.M., 1971. The behaviour of the domestic fowl (No. 7). Heinemann Educational Books Ltd., Edinburgh.

Zimecki M., Artym J., 2004. Wpływ stresu psychicznego na odpowiedź immunologiczną. Postep Hig. Med. Dosw. (on line) 58, 166-175. 
Magdalena Sobuś ${ }^{1,2}$, Karolina Burczyn ${ }^{1}$, Aleksandra Drzał ${ }^{1}$, Paulina Iwase ${ }^{1}$, Agata Klisiewicz ${ }^{1}$

\title{
Jakościowa ocena kondycji koni z wykorzystaniem współczynnika BCS
}

\author{
Quantitative assessment of equine silhouette using body condition score coefficient
}

\begin{abstract}
Wstęp
Body condition score (BCS) jest metodą oceny stanu kondycji zwierzęcia, opierającą się na skali liczbowej z określonymi kryteriami dla każdej kategorii. Metoda polega na wizualnej i fizycznej (palpacyjnej) ocenie odkładania się podskórnego tłuszczu w określonych obszarach ciała. W celu ułatwienia oceny stanu kondycji opracowano kilka rodzajów skali stosowanych u koni.

Skala w zakresie $0-5$ punktów została opisana przez Carrolla i Huntingtona [1988] (tab. 1). System ten poddaje ocenie trzy obszary ciała (szyję, grzbiet i żebra oraz zad). Każdy obszar jest oceniany osobno. Jeżeli ocena zadu różni się o 1 punkt lub więcej od oceny szyi czy grzbietu, to jest korygowana o 0,5 punktu, aby uzyskać ogólny BCS.

Inną, powszechnie stosowaną u koni i kuców metodą oceny zawartości tkanki thuszczowej jest system BCS opracowany przez Henneke i in. [1983]. Obejmuje on ocenę sześciu obszarów ciała (szyi, kłębu, grzbietu, ogona, żeber i okolicy ramienia) w skali od 1 do 9, przy czym 1 oznacza skrajne wychudzenie, a 9 - otyłość (tab. 2). Każdy obszar ciała jest oceniany osobno, następnie wyniki są uśredniane w celu uzyskania ogólnego wyniku dotyczącego kondycji ciała. System Henneke, pierwotnie opracowany do wykorzystania w hodowli koni rasy american quarter horse, może być najbardziej odpowiedni do stosowania u dojrzałych koni ras lekkich (np. quarter horse, koni czystej krwi arabskiej), które mają podobny typ ciała i wzorce odkładania thuszczu. Opisano zastosowanie systemu BCS dla wałachów pełnej krwi angielskiej [Suagee i in. 2008], a także opracowano zmiany w systemie BCS w celu zwiększenia jego przydatności dla ras gorącokrwistych [Kienzle i Schramme 2004].
\end{abstract}

\footnotetext{
${ }^{1}$ Uniwersytet Przyrodniczy w Lublinie, Wydział Medycyny Weterynaryjnej, Studenckie Koło Naukowe Medyków Weterynaryjnych, Sekcja Hipiatryczna

${ }^{2}$ sobusmagda@gmail.com
} 
Tabela 1. Skala BCS wg Carolla i Huntingtona na podstawie skali Leightona-Hardmana [1980]

\begin{tabular}{|c|c|c|c|}
\hline $\mathrm{BCS}$ & Szyja & Grzbiet i żebra & Miednica i zad \\
\hline 0 & $\begin{array}{l}\text { wąska, niedostatecznie } \\
\text { umięśniona, z wyraźnie } \\
\text { zaznaczonym wklęśnięciem } \\
\text { po stronie dogrzbietowej }\end{array}$ & $\begin{array}{l}\text { skóra ciasno opina żebra, } \\
\text { wyrostki kolczyste ostre } \\
\text { i dobrze widoczne }\end{array}$ & $\begin{array}{l}\text { zad kanciasty, kości dobrze } \\
\text { widoczne, ciasno opięte skórą; } \\
\text { zad wklęsły zarówno na obu } \\
\text { pośladkach, jak i pod ogonem }\end{array}$ \\
\hline 1 & $\begin{array}{l}\text { wąska, niedostatecznie } \\
\text { umięśniona, z nieznacznie } \\
\text { zaznaczonym wklęśnięciem } \\
\text { po stronie dogrzbietowej }\end{array}$ & $\begin{array}{l}\text { żebra dobrze widoczne, } \\
\text { grzbiet zapadnięty, wyraźnie } \\
\text { zaznaczone wyrostki } \\
\text { kolczyste }\end{array}$ & $\begin{array}{l}\text { zad zapadnięty, wyraźna } \\
\text { wklęsłość pod ogonem }\end{array}$ \\
\hline 2 & mocna, ale wąska & $\begin{array}{l}\text { żebra lekko widoczne, grzbiet } \\
\text { prawidłowo umięśniony, } \\
\text { wyrostki kolczyste } \\
\text { wyczuwalne }\end{array}$ & $\begin{array}{l}\text { zad płaski, pokryty niewielką } \\
\text { warstwą tłuszczu, nieznaczna } \\
\text { wklęsłość pod ogonem }\end{array}$ \\
\hline 3 & mocna, grzebień nie występuje & $\begin{array}{l}\text { żebra niewidoczne, ale łatwo } \\
\text { wyczuwalne, wyrostki } \\
\text { kolczyste przykryte, lecz } \\
\text { wyczuwalne }\end{array}$ & $\begin{array}{l}\text { zad pokryty warstwą tłuszczu } \\
\text { i zaokrąglony, kości miednicy } \\
\text { łatwo wyczuwalne }\end{array}$ \\
\hline 4 & $\begin{array}{l}\text { szeroka i mocna, grzebień lekko } \\
\text { zaznaczony }\end{array}$ & $\begin{array}{l}\text { żebra zakryte i wyczuwalne } \\
\text { pod mocniejszym naciskiem, } \\
\text { liniowa wklęsłość wzdłuż } \\
\text { grzbietu }\end{array}$ & $\begin{array}{l}\text { rozłupany zad, kości miednicy } \\
\text { dobrze pokryte tłuszczem } \\
\text { i wyczuwalne dopiero pod } \\
\text { mocniejszym naciskiem }\end{array}$ \\
\hline 5 & $\begin{array}{l}\text { szeroka i mocna, wyraźnie } \\
\text { zaznaczony grzebień, } \\
\text { widoczne wałki tłuszczu }\end{array}$ & $\begin{array}{l}\text { żebra niewyczuwalne, szeroki } \\
\text { i płaski grzbiet, silnie } \\
\text { zaznaczona liniowa wklęsłość } \\
\text { wzdłuż kręgosłupa }\end{array}$ & $\begin{array}{l}\text { rozłupany zad, kości miednicy } \\
\text { niewyczuwalne }\end{array}$ \\
\hline
\end{tabular}

Istnieją doniesienia o zastosowaniu systemu BCS według Henneke do opisu wałachów pełnej krwi angielskiej [Suagee i in. 2008]. W tym celu przebadano 15 dojrzałych koni tej rasy, a ich punktacja była efektem pracy dwóch oceniających. Wyniki wspomnianych badań wykazały, iż pomiędzy punktem 4 a 7 istnieją duże niespójności w opisie poszczególnych cech odzwierciedlających odkładanie się tłuszczu w danych obszarach ciała. $\mathrm{Z}$ tego powodu zaproponowano bardziej szczegółową charakterystykę wyników akumulacji tłuszczu w tych obszarach [Henneke i in. 1983]. 
Tabela 2. Skala BCS wg Henneke

\begin{tabular}{|c|c|c|}
\hline $\mathrm{BCS}$ & Wyszczególnienie & Opis \\
\hline 1 & $\begin{array}{l}\text { ekstremalnie } \\
\text { chudy }\end{array}$ & $\begin{array}{l}\text { Zwierzę bardzo wychudzone, wyraźnie wystające wyrostki kolczyste, żebra, } \\
\text { nasada ogona, guz biodrowy i kulszowy. Zauważalne kości kłębu, ramion i szyi, } \\
\text { nie można wyczuć tkanki tłuszczowej. }\end{array}$ \\
\hline 2 & bardzo chudy & $\begin{array}{l}\text { Zwierzę wychudzone, niewielki tłuszcz pokrywa podstawę wyrostków kolczys- } \\
\text { tych, wyrostki poprzeczne kręgów lędźwiowych są zaokrąglone. Wystające wy- } \\
\text { rostki kolczyste, żebra, nasada ogona, guz biodrowy i kulszowy. Słabo } \\
\text { dostrzegalne kości kłębu, ramion i szyi. }\end{array}$ \\
\hline 3 & chudy & $\begin{array}{l}\text { Tłuszcz gromadzi się mniej więcej w połowie wyrostków kolczystych, wyrostki } \\
\text { poprzeczne nie są wyczuwalne. Nieznaczna pokrywa thuszczowa nad żebrami. } \\
\text { Łatwo dostrzegalne wyrostki kolczyste i żebra. Głowa wydatna, ale pojedynczych } \\
\text { kręgów nie da się zobaczyć. Guz biodrowy wydaje się być zaokrąglony, ale łatwo } \\
\text { dostrzegalny. Guz kulszowy nierozróżnialny. Kłąb, ramiona i szyja zaakcentowane. }\end{array}$ \\
\hline 4 & $\begin{array}{l}\text { umiarkowanie } \\
\text { chudy }\end{array}$ & $\begin{array}{l}\text { Grzbiet nieznacznie nadbudowany. Dostrzegalny słaby zarys żeber. Wokół nasady } \\
\text { ogona można wyczuć tłuszcz. Guz biodrowy niedostrzegalny. Kłąb, ramiona } \\
\text { i szyja niezbyt chude. }\end{array}$ \\
\hline 5 & umiarkowany & $\begin{array}{l}\text { Grzbiet w poziomie. Żeber nie można odróżnić wizualnie, ale łatwo wyczuć. } \\
\text { Wyczuwalny jako gąbczasty tłuszcz wokół nasady ogona. Kłąb wydaje się być } \\
\text { zaokrąglony. Ramiona i szyja wtapiają się płynnie w ciało. }\end{array}$ \\
\hline 6 & $\begin{array}{l}\text { umiarkowanie } \\
\text { mięsisty }\end{array}$ & $\begin{array}{l}\text { Możliwa niewielka fałda utworzona z tłuszczu na grzbiecie. Wyczuwalny gąbcza- } \\
\text { sty tłuszcz nad żebrami. Tłuszcz wokół nasady ogona jest miękki. Tłuszcz zaczyna } \\
\text { odkładać się na kłębie, za ramionami i po bokach szyi. }\end{array}$ \\
\hline 7 & mięsisty & $\begin{array}{l}\text { Możliwa fałda na grzbiecie. Poszczególne żebra mogą być wyczuwalne, ale za- } \\
\text { uważalne jest wypełnienie tłuszczem między nimi. Tłuszcz wokół nasady ogona } \\
\text { jest miękki. Tłuszcz odłożony wzdłuż kłębu, za ramionami i na szyi. }\end{array}$ \\
\hline 8 & otyły & $\begin{array}{l}\text { Fałda na grzbiecie. Trudno wyczuć żebra. Tłuszcz wokół ogona bardzo miękki. Obszar } \\
\text { wzdłuż kłębu wypełniony tłuszczem. Obszar za ramieniem wypełniony thuszczem. } \\
\text { Zauważalne pogrubienie szyi. Odłożony tłuszcz po wewnętrznej części ud. }\end{array}$ \\
\hline 9 & bardzo otyły & $\begin{array}{l}\text { Wyraźnie widoczna fałda na grzbiecie. Pojawia się niejednolity tłuszcz nad żebra- } \\
\text { mi. Wypukły tłuszcz wokół nasady ogona, wzdłuż kłębu, za ramionami i wzdłuż } \\
\text { szyi. Tłuszcz po wewnętrznej stronie ud, uda mogą się ocierać o siebie. Bok } \\
\text { wypełniony tłuszczem. }\end{array}$ \\
\hline
\end{tabular}

\section{Badania własne}

Badania przeprowadzono na dziesięciu koniach różnej płci, będących pacjentami klinik weterynaryjnych UP w Lublinie. Grupę badawczą charakteryzował zróżnicowany wiek, w zakresie od 8 miesięcy do 31 lat (mediana wieku 11,5). Badane konie należały do ras gorącokrwistych (sp, małopolskiej), jeden był rasy huculskiej.

Do oceny body condition score wykorzystano skalę według Henneke z uwagi na jej potwierdzoną dokładność. Dokonywały jej dwa oddzielne zespoły (po dwie osoby w każdym), wzorując się na innych podobnych badaniach uwzględ- 
niających kilka niezależnych ocen [Burkholder 2000]. Każdego konia na początku oglądano w boksie, następnie dokonano oceny palpacyjnej. Skupiono się na charakterystycznych dla skali BCS punktach - szyi, żebrach, nasadzie ogona, mięśniach ud, widoczności łopatek oraz kłębu. Następnie konie zostały kolejno wyprowadzone przed stajnię, aby wykonać każdemu z nich zdjęcia w celu potwierdzenia ewentualnych wątpliwości.

Niezależnie od ocen BCS w innym dniu dokonano pomiaru masy ciała zwierząt. W tym celu wykorzystano elektroniczną wagę platformową firmy Ohaus model T71XW. Urządzenie umożliwia odczyt masy ciała zwierzęcia w kilku jednostkach, w tym kilogramach, do badań posłużono się ich odczytem. Zakres pomiarowy wagi wynosi do $9999 \mathrm{~kg} \mathrm{z}$ dokładnością do $1: 500(0,002)$. Konie były wprowadzane zawsze $\mathrm{z}$ tej samej strony, a następnie dążono do utrzymania ich $\mathrm{w}$ nieruchomości przez przynajmniej $5 \mathrm{~s}$ (czas stabilizacji wagi wynosi do $2 \mathrm{~s}$ ).

Fotografie 1-4 są ilustracją oceny BCS wybranych koni.

Koń nr 3 - waga $400 \mathrm{~kg}$, ocena 5 (umiarkowany) i 4 (umiarkowanie chudy). Półtoraroczny wałach (fot. 1) po przebytym niedawno zabiegu kastracji. Zbudowany proporcjonalnie, stosownie do swojego wieku. Żebra słabo widoczne, jednak wyczuwalne (ocena 4), kłąb jest zaokrąglony (5), a wokół nasady ogona wyczuwalna niewielka ilość tłuszczu (4).

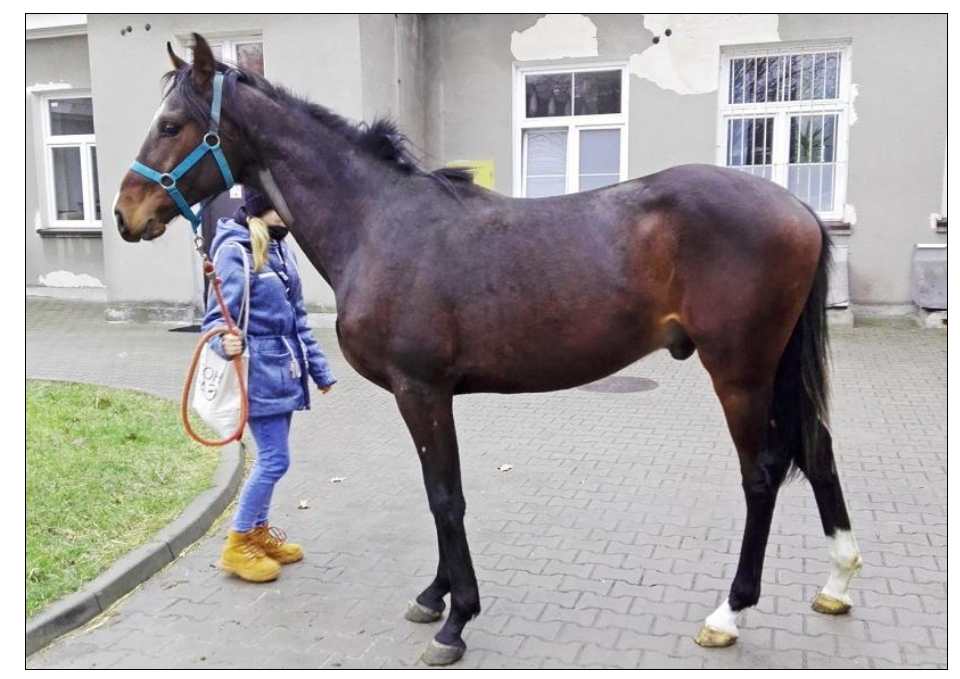

Fot. 1. Koń nr 3 (fot. M. Sobuś)

Koń nr 6 - waga $536 \mathrm{~kg}$, ocena 3 (chudy) i 2 (bardzo chudy). Dziewiętnastoletnia klacz (fot. 2), chorująca, z przewlekłymi objawami ze strony układu oddechowego. Żebra widoczne są nawet pomimo zimowej sierści, wyraźnie wyczuwalne (3). Wyrostki poprzeczne są ciężkie do wyczucia (3). Kłąb, kości ramion i szyi są słabo dostrzegalne (2). Pojedyncze kręgi szyjne niewidoczne (3). 


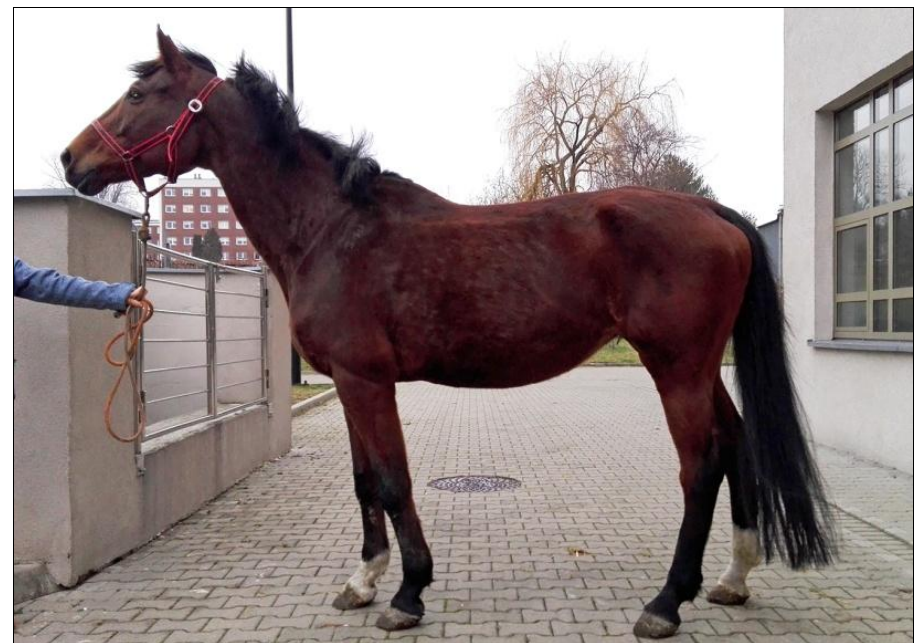

Fot. 2. Koń nr 6 (fot. M. Sobuś)

Koń nr 9 - waga $693 \mathrm{~kg}$, ocena 7 (mięsisty) i 8 (otyły). Trzydziestojednoletnia klacz (fot. 3), niepracująca pod siodłem, jedynie padokowana. Żebra są trudno wyczuwalne (8). Wyraźnie wyczuwalny miękki tłuszcz wokół nasady ogona (8). Fałda na grzbiecie nie jest wyraźnie widoczna (7). Mocno wyczuwalny tłuszcz za ramionami i na szyi (7), pogrubienie szyi jest zauważalne (8).

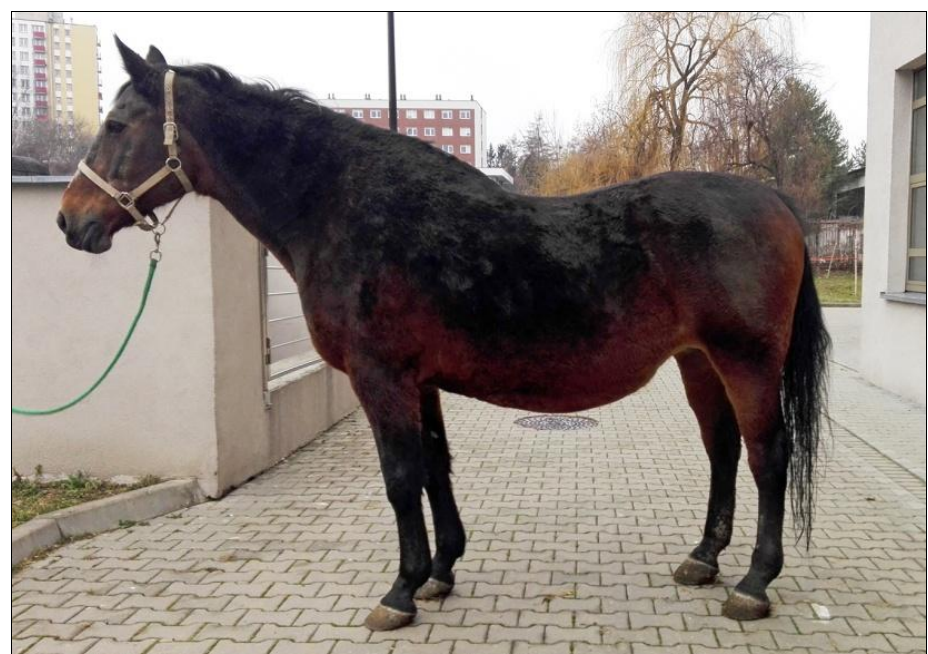

Fot. 3. Koń nr 9 (fot. M. Sobuś)

$\mathrm{Na}$ fotografii 4 pokazano dla porównania stopień otłuszczenia trzech koni (nr 3,6,9), obserwowanych od tyłu. Konie uszeregowane są od najlżejszego (od lewej). Już na pierwszy rzut oka widać, iż waga nie koreluje ze stopniem otłusz- 
czenia. U konia nr 6 najbardziej widoczne są guzy biodrowe, najmniej jest thuszczu u nasady ogona oraz po wewnętrznej stronie ud. U najcięższego konia $\mathrm{nr} 9$ widać okrągły zad, mocno otłuszczoną nasadę ogona i tłuszcz po wewnętrznej stronie ud. Koń nr 3 z racji młodego wieku i „dziecięcej” sylwetki powinien znaleźć się pomiędzy końmi nr 6 i 9, jeżeli chodzi o stopień otłuszczenia, pomimo iż wagowo jest $z$ nich najlżejszy.

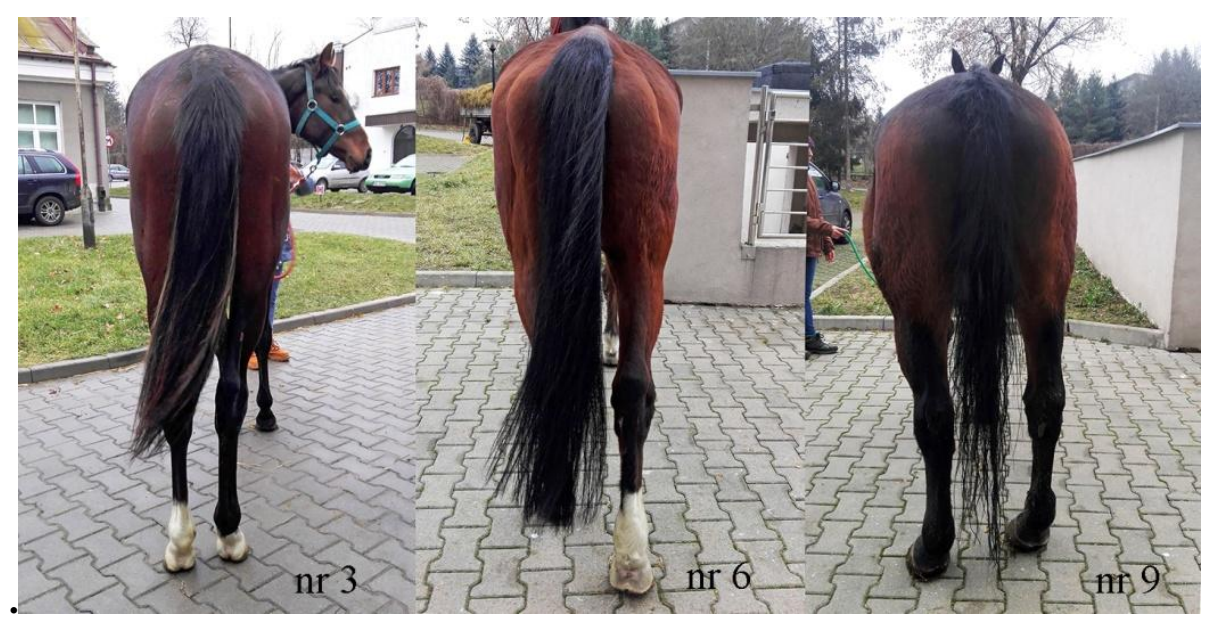

Fot. 4. Porównanie koni nr 3, 6 i 9 (fot. M. Sobuś)

Wyniki przedstawiono w tabeli 4 , konie uszeregowano pod względem wagi od najlżejszego do najcięższego. Zabieg ten miał na celu skorelowanie oceny BCS z rzeczywistą wagą. BCS umożliwia nam bowiem jedynie ocenę jakościową masy ciała, stwierdzenie, czy koń cechuje się niedowagą bądź nadwagą. W wielu przypadkach jest to wystarczająca informacja podczas ustalania lub modyfikowania dawki pokarmowej. Waga rzeczywista w kilogramach będąca metodą ilościową jest oczywiście bardziej dokładna, przydatna podczas ustalania dawek leków czy preparatów przeciwpasożytniczych.

Warto zwrócić uwagę na różnice w ocenie BCS pomiędzy dwoma zespołami. Podkreśla to subiektywny charakter skali, tylko dla trzech koni oceny były zgodne. W pozostałych przypadkach różniły się o 1 punkt, czterokrotnie zespół nr 1 wystawiał wyższą ocenę, dwukrotnie zaś zespół nr 2 . W kilku przypadkach oba zespoły wskazały ocenę pomiędzy jednym a drugim punktem, ponieważ skala nie uwzględnia wartości połówkowych. W sytuacjach wątpliwych za wynik przyjęto każdorazowo ocenę niższą.

Można zauważyć pewne korelacje pomiędzy oceną body condition score a wagą zwierząt, jednak i w tym przypadku zdarzają się wyjątki. Koń nr 4 pomimo masy ciała 493,5 kg został oceniony odpowiednio na 4 i 3 punkty, podczas gdy dwa lżejsze od niego konie oceniono o 1-2 punkty wyżej. Jeszcze bardziej różnica widoczna jest w przypadku konia nr 6, ważącego $546 \mathrm{~kg}$, ocenio- 
nego na 3 i 2 punkty, co jest zdecydowanie niższym wynikiem niż w przypadku konia nr 5 o wadze 546 kg, który uzyskał oceny 5 i 4 . Dowodzi to, iż konie o podobnej masie ciała i porównywalnym wzroście (nr 5 i 6) mogą diametralnie różnić się oceną BCS. Waga nie uwzględnia tego, jak koń wygląda, ile ma mięśni oraz czy jego budowa ciała jest proporcjonalna. Pod tym względem dokładniejszą ocenę uzyskujemy, używając skali. Często zwierzę ważące mniej, charakteryzujące się symetrią sylwetki, odpowiednimi proporcjami oraz umięśnieniem, uzyska więcej punktów. Można zatem wysnuć wniosek, że chociaż skala BCS nie przedstawia dokładnych informacji o masie ciała, to mając do dyspozycji jedynie ocenę konia, jesteśmy w stanie dowiedzieć się więcej na temat jego budowy, niż znając samą masę ciała.

Tabela 4. Zestawienie wyników badań

\begin{tabular}{|c|c|c|c|c|c|}
\hline L.p. & Płeć & $\begin{array}{c}\text { Wiek } \\
(\text { lata })\end{array}$ & $\begin{array}{c}\text { Pomiar } \\
\text { na wadze }(\mathrm{kg})\end{array}$ & BCS zespół 1 & BCS zespół 2 \\
\hline 1 & ogier & 8 mies. & 290 & 4 & 4 \\
\hline 3 & ogier & 3 & 340 & 5 & 6 \\
\hline 2 & wałach & 1,5 & 400 & 5 & 4 \\
\hline 4 & wałach & 26 & 493,5 & 4 & 3 \\
\hline 5 & ogier & 5 & 522 & 5 & 5 \\
\hline 6 & klacz & 16 & 550 & 4 & 6 \\
\hline 7 & klacz & 19 & 546 & 6 & 6 \\
\hline 8 & klacz & 11 & 650 & 6 & 8 \\
\hline 9 & wałach & 14 & 650 & 7 & 6 \\
\hline 10 & klacz & 31 & 693 & & 6 \\
\hline
\end{tabular}




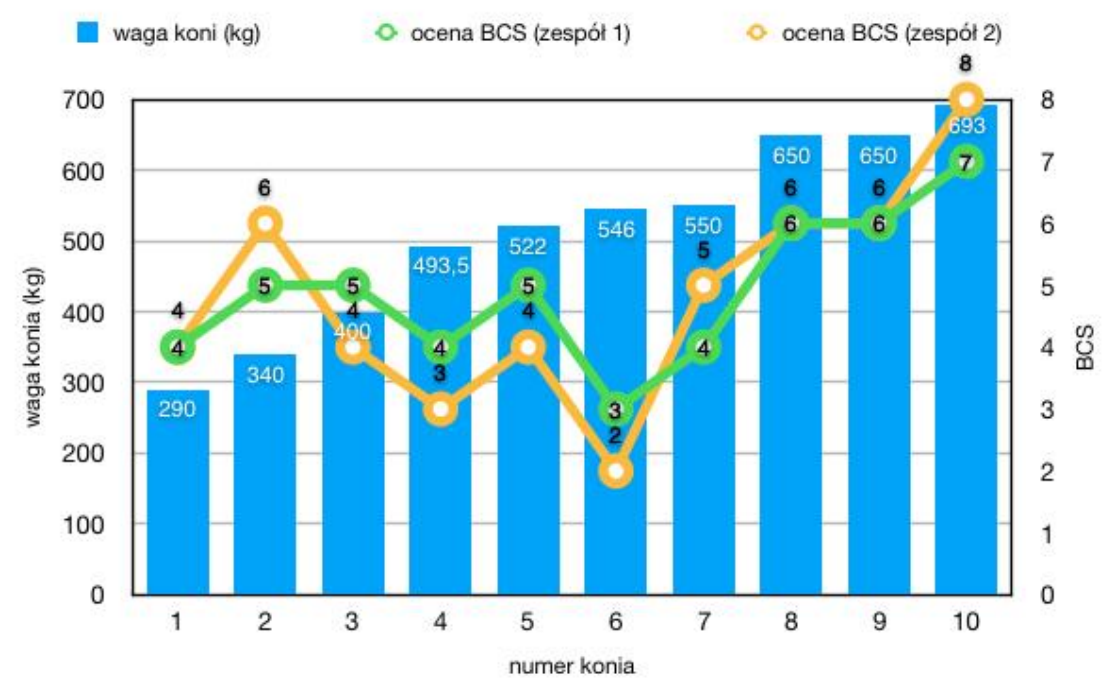

Rys. 1. Porównanie oceny BCS z wagą badanych koni

W celu wizualizacji wyników posłużono się wykresem (rys. 1), niebieskie słupki przedstawiają pomiar masy ciała przy użyciu wagi elektronicznej. Wyniki uszeregowano od najlżejszego do najcięższego konia. Dzięki temu widać, iż ocena BCS nie zachowuje tego samego trendu. Ukazane są także różnice pomiędzy ocenami zespołu nr 1 (kolor zielony) oraz zespołu nr 2 (kolor pomarańczowy).

\section{Podsumowanie}

Body condition score jest jakościową metodą oceny kondycji otłuszczenia koni przydatną $\mathrm{w}$ wielu sytuacjach, jednak obarczoną pewnymi wadami. W porównaniu z pomiarem masy ciała na wadze BCS w lepszy sposób odzwierciedla wygląd i prawidłowość sylwetki zwierząt. Niestety, jest to metoda subiektywna. Aby wynik był jak najbardziej dokładny, pomiar powinien być wykonywany przez kilka osób, a następnie uśredniany. Podobna sytuacja dotyczy budowy koni - poszczególne części ciała mogą być ocenione różnie. W takich sytuacjach należy obserwować całe zwierzę i zdecydować, do której kategorii punktowej należy więcej elementów. Aby ocenę wg skali BCS uznać za wartościową, powinna spełniać trzy warunki: powtarzalność, odtwarzalność oraz przewidywalność. Powtarzalność oznacza, iż ta sama osoba, oceniając tego samego konia, za każdym razem daje mu identyczną ocenę. Odtwarzalność dotyczy jednakowych ocen wskazanych przez dwóch niezależnych oceniających. Przewidywalność ma zaś związek z obliczeniami matematycznymi tkanki thuszczowej opracowanymi przez Henneke [Evans 1978]. Pomimo wspomnianej subiektywności na podstawie ocenionych koni można potwierdzić dużą przydatność skali. Pierwsze wra- 
żenie, jakie na oceniających zrobiły poszczególne konie (chudy, normalny, gruby), potwierdziło się w ich ocenach. Różnice w wynikach pomiędzy oceniającymi były niewielkie, dlatego też skalę uznajemy za pomocną w kontroli masy ciała i wyglądu sylwetki zwierząt. Można w ten sposób porównać wygląd konia przed i po sezonie hodowlanym czy sportowym, ocenić wpływ zwiększenia dawki pokarmowej u wychudzonego konia czy też potwierdzić prawidłowe żywienie.

\section{Bibliografia}

Burkholder W.J., 2000. Use of body condition scores in clinical assessment of the provision of optimal nutrition. J. Am. Vet. Med. Assoc. 217, 650-654.

Carroll C.L., Huntington P.J., 1988. Body condition scoring and weight estimation of horses. Equine Vet. J. 20(1), 41-45.

Evans D.G., 1978. The interpretation and analysis of subjective body condition scores. Anim. Prod. 26, 119-125.

Henneke D.R., Potter G.D., Kreider J.L. i in., 1983. Relationship between condition score, physical measurements and body fat percentage in mares. Equine Vet. J. 15(4), 371-372.

Kienzle E., Schramme S.C., 2004. Body condition scoring and prediction of body weight in adult warm blooded horses. Pferdeheilkunde 20(6), 517-524.

Leighton-Hardman A.C., 1980. Equine Nutrition. Pelham Bookds, London, 9-17.

Suagee J.K., Burk A.O., Quinn R.W., Petersen E.D., Hartsock T.G., Douglass L.W., 2008. Effects of diet and weight gain on body condition scoring in thoroughbred geldings. J. Equine Vet. Sci. 28(3), 156-166. 
Magdalena Sobuś ${ }^{1,2}$, Nikola Adamczyk ${ }^{1}$, Magdalena Tarach $^{1}$

\title{
Rzekomy rak kopyta - etiologia, leczenie. Opis przypadku
}

\author{
Equine hoof canker - etiology and treatment. A case report
}

Rzekomy rak kopyta - pododermatitis chronica verrucosa - jest niszczącym, przerostowym zapaleniem warstwy brodawkowej skóry właściwej podeszwy, strzałki oraz ściany kopyta. W tym przypadku keratynocyty nie ulegają rogowaceniu, a przerostowi. Jednak nie dochodzi tu do nadmiernej proliferacji tkanki brodawkowatej skóry, jak kiedyś sądzono [Apprich i Licka 2013].

Choroba diagnozowana jest zazwyczaj jako nitkowate lub kalafiorowate rozrosty macierzy kopyta z towarzyszącym nieprzyjemnym zapachem oraz białym, serowatym wysiękiem. Rak kopyta jest zaburzeniem przewlekłym, a w późniejszym stadium zagraża użytkowaniu i dobrostanowi konia. Zmiany dotyczą często więcej niż jednej kończyny, co skutkuje niemożnością użytkowania zwierzęcia oraz pogorszeniem jego dobrostanu. Ze względu na brak w pełni skutecznej terapii ta choroba często prowadzi do konieczności poddania zwierzęcia eutanazji [Wilson i in. 1989, Stashak 2002, Dietz 2006, Knottenbelt 2009, Apprich i Licka 2013].

\section{Etiologia}

Uznaje się, iż rzekomy rak kopyta nie ma jednej konkretnej przyczyny. Czynnikami sprawczymi mogą być: nieodpowiednio prowadzona hodowla i użytkowanie koni - brak higieny kopyt, nadmierna wilgotność podłoża, nieprawidłowe rozczyszczanie kopyt. Teoria ta jednak wydaje się błędna, gdyż schorzenie pojawia się również u koni zadbanych, regularnie struganych i prawidłowo podkutych. Rak często jest bardzo późno diagnozowany, gdyż we wczesnym stadium mylony jest $\mathrm{z}$ bakteryjnym zakażeniem wywoływanym zazwyczaj przez bakterie beztlenowe, które dotyka w szczególności okolic strzałki. Bakterie bytują w środowisku wilgotnym, zanieczyszczonym, z małą ilością tlenu - w zaniedbanych boksach i stanowiskach. Rozwijają się w rowkach strzałki - bocznym i środkowym zwłaszcza gdy róg strzałki jest znacznie przerośnięty, a rowki głębokie. Natomiast rzekomy rak kopyta związany jest ze zmianami rogowacenia kopyta.

\footnotetext{
${ }^{1}$ Uniwersytet Przyrodniczy w Lublinie, Wydział Medycyny Weterynaryjnej, Studenckie Koło Naukowe Medyków Weterynaryjnych, Sekcja Hipiatryczna

${ }^{2}$ sobusmagda@gmail.com
} 
Istotną różnicą jest to, iż w przypadku zakażenia bakteryjnego strzałki występuje utrata tkanki, a zmiany przy rzekomym raku są rozrostowe [Redding i O'Grady 2012]. Podejrzewa się również predyspozycje genetyczne - nadmierny i nieprawidłowy rozrost strzałki oraz autoagresję systemu immunologicznego zwierzęcia [Knottenbelt 2009].

Ostatnie badania wykazały również, że jedną z przyczyn może być sarkoidoza. W stu procentach próbek tkanki rakowej oraz skóry zdrowej i krwi od koni chorych wykryto obecność DNA wirusa brodawczaka bydlęcego typu 1 i 2 [Jongbloets $i$ in. 2005, Brandt $i$ in. 2010]. DNA wirusa brodawczaka nie zostało wykryte u zdrowych koni. Dodatkowo w badaniu klinicznym oraz histopatologicznym sarkoidy koni są zbliżone do tkanki rzekomego raka kopyt [Rooney i Robertson 1996]. Badania morfologiczne zmienionych tkanek są jednak wykonywane rzadko. Trudno jednoznacznie określić czynnik inicjujący powstawanie zmian rakowych.

W połowie XX w. uważano, że choroba dotyczy głównie koni pociągowych, ale ostatnie badania temu zaprzeczyły. Wiadomo, że zmiany rakowe występuja zarówno u koni zimnokrwistych, gorącokrwistych, jak i u ras prymitywnych [Apprich i in. 2017].

\section{Leczenie - przegląd literatury}

Nieleczony proces chorobowy w przypadku rzekomego raka kopyt ma charakter rozwojowy. Choroba rozpoczyna się od zajęcia strzałki, następnie przechodzi na podeszwę i kolejno warstwę pośrodkową ściany. Ze względu na nie do końca poznaną etiologię rzekomego raka kopyt, leczenie jest złożone. Niezależnie od wybranej metody leczenia podstawą jest usunięcie nieprawidłowej tkanki.

Do leczenia rzekomego raka kopyt najczęściej stosuje się kombinację kilku metod, takich jak: usunięcie chirurgiczne wraz opatrunkami uciskowymi, antybiotykoterapia, krioterapia, stosowanie prednisolonu p.o., leki przeciwgrzybicze, terapia cisplatyną. Jednogłośnie wszyscy autorzy prac na temat leczenia pododermatitis verucosa chronica zgadzają się, iż podstawą jest chirurgiczne usunięcie zmienionej chorobowo tkanki, a następnie zastosowanie terapii wspomagającej [Mason 1962, Minami i in. 1991, Rowlands 2014]. Pierwsze doniesienia Masona [1962] opisują skuteczność podawania penicyliny w połączeniu z jej miejscowym zastosowaniem po chirurgicznym usunięciu nieprawidłowej tkanki. Niektórzy autorzy [Banic i Skusek 1960] uznali zaś stosowanie penicyliny za skuteczne tylko w $10 \%$ przypadków.

Japońscy lekarze [Minami i in. 1991] po chirurgicznym usunięciu chorobowo zmienionej tkanki, przed założeniem opatrunku, smarowali kopyta dziegciem. Dodatkowo stosowali iniekcje z ampicyliny przez trzy dni po zabiegu. Współcześnie jedną z metod wspomagania leczenia chirurgicznego jest krioterapia [Redding i O’Grady 2012]. 
Wraz z rozwojem medycyny weterynaryjnej możliwe stało się wykonywanie zabiegów na koniu leżącym $\mathrm{w}$ znieczuleniu ogólnym lub na koniu stojącym z zastosowaniem znieczulenia miejscowego. Podczas zabiegu dąży się do całkowitego wycięcia nieprawidłowych tkanek. Ważnym elementem operacji jest zminimalizowanie krwawienia poprzez zastosowanie lateksowej opaski uciskowej (np. Esmarch) ponad stawem pęcinowym. Dzięki temu krew z naczyń żylnych (v. digitalis palmaris propria III lat. et med.) jest odprowadzona do góry, a zaciśnięcie opaski zapobiega dopływowi krwi do tętnic palcowych (a. digitalis palmaris propria III lat. et med.). Zaleca się usunięcie chorej tkanki z marginesem bezpieczeństwa, co zmniejsza ryzyko nawrotu choroby. Istnieją doniesienia [Redding i O'Grady 2012] o stosowaniu krioterapii po zabiegu, przy użyciu ciekłego azotu lub za pomocą sprayu chłodzącego przeznaczonego do obwodów elektrycznych (np. Component Cooler Radio Shark Corp.). Należy chłodzić miejsca wyciętych struktur, aż staną się twarde. Redding i O'Grady [2012] następnie zalecają stosowanie gazików nasączonych $10 \%$ nadtlenkiem benzoitu. Wykazuje on działanie przeciwzapalne, przeciwbakteryjne i łagodnie keratolityczne. Dodatkowo ci sami autorzy stosowali pokruszone tabletki $500 \mathrm{mg}$ metronidazolu pod opatrunki uciskowe na kopytach. Podkreślana jest także istotność zachowania czystości w boksie, czyszczenie kopyt oraz moczenie ich w aseptycznym roztworze podczas zmian opatrunków. Redding [2012] zaproponował wykonanie metalowej podeszwy przykręcanej na hacele do podkowy, dzięki czemu zmiana opatrunków jest łatwa i zajmuje mniej czasu.

Istnieją doniesienia [Wilson 1997] o skuteczności stosowania wspomagająco do terapii chirurgicznej prednisolonu w dawce $1 \mathrm{mg} / \mathrm{kg}$ m.c. co $24 \mathrm{~h}$ przez $7 \mathrm{dni}$. Przez kolejne 7 dni podaje się połowę dawki, a przez następne $7-0,35 \mathrm{mg} / \mathrm{kg}$ m.c. Ponieważ istnieje podejrzenie, iż choroba ma charakter autoimmunologiczny, stosowanie prednisolonu uznano za uzasadnione i w niektórych przypadkach skuteczne.

Lekarze z Uniwersytetu w Ghent [Oosterlinck i in. 2011] zwracają uwagę na szczepienia przeciwko tężcowi przed wykonaniem zabiegu chirurgicznego. Leczone przez nich konie dostawały lek przeciwzapalny (flunixyna w dawce $1,1 \mathrm{mg} / \mathrm{kg}$ m.c.) oraz ochronę antybiotykową w postaci penicyliny prokainowej (15 000 jednostek $/ \mathrm{kg} \mathrm{m.c.).} \mathrm{Autorzy} \mathrm{po} \mathrm{zabiegu} \mathrm{na} \mathrm{podeszwę} \mathrm{kopyta} \mathrm{stosowali}$ miejscowo trimpetoprim z sulfadiazyną w proszku. W najcięższych przypadkach przedłużono antybiotykoterapię $\mathrm{W}$ postaci trimetoprimu $\mathrm{z}$ sulfadiazyną (30 mg/kg m.c.) do kolejnych 1-3 tygodni. W omówionych badaniach czas leczenia wynosił średnio kilka tygodni, jednak wedle doniesień z innych źródeł może się on znacznie wydłużyć, nawet do kilku miesięcy [Fürst i Lischet 2006].

Brandt $i$ in. [2010] w prowadzonych przez siebie badaniach we wszystkich analizowanych przypadkach $\mathrm{w}$ tkance dotkniętych rzekomym rakiem kopyta wyizolowali papillomawirus typu 1 i 2. Według Rooneya i Robertsona [1996] występuje pewne podobieństwo między rzekomym rakiem kopyta a sarkoidami $\mathrm{u}$ koni. W związku z tym zwrócono uwagę na wykorzystanie cisplatyny, która ma szerokie zastosowanie w medycynie ludzkiej i weterynaryjnej - w leczeniu 
sarkoidów u koni [Hewes i Sullins 2006, Theon i in. 2007]. Pomyślne stosowanie cisplatyny w leczeniu rzekomego raka kopyt opisali Apprich i Licka [2013]. Terapia polegała na codziennych 10 aplikacjach chemioterapeutyku $\mathrm{w}$ postaci pasty w miejscu przeprowadzonego zabiegu. Podczas chemioterapii oraz dwa dni po jej zakończeniu konie były trzymane w izolatce, z dala od innych zwierząt i ludzi. Spośród 10 leczonych koni u 2 konieczne było ponowne usuwanie rakowej tkanki przed rozpoczęciem chemioterapii, u kolejnych 2 podejrzana tkanka została usunięta ponownie po piątym podaniu cisplatyny. Średni czas hospitalizacji dla koni leczonych cisplatyną wynosił 32,1 dnia. Wszystkie konie były monitorowane po zakończeniu leczenia do 14 miesięcy i tylko u jednego nastąpił nawrót choroby 13 miesięcy po wypisaniu z kliniki. Podczas i po zakończonej terapii nie zauważono żadnych miejscowych ani uogólnionych skutków ubocznych stosowania cisplatyny. Odkrycie nowych, skutecznych metod leczenia jest istotne, ponieważ w przeszłości brak postępów prowadził nawet do decyzji o eutanazji [Knottenbelt 2009].

Rowlands [2014] oprócz wymienionych wcześniej metod stosuje miejscowo metronidazol w celu zwalczania bakterii beztlenowych. Metronidazol można zastąpić innymi środkami antybakteryjnymi zawierającymi tetracykliny, sulfapirydynę lub mieszanki z DMSO. Na każdą z tych substancji konieczne jest założenie opatrunku.

\section{Opis przypadku}

Jedenastoletnia klacz użytkowana sportowo została przyjęta do Kliniki Weterynaryjnej Uniwersytetu Przyrodniczego w Lublinie. Koń przyjechał z podejrzeniem rzekomego raka kopyt postawionym przez lekarza weterynarii podczas wizyty terenowej. Zwierzę nie wykazywało kulawizny w stępie ani w kłusie. Po przyjęciu klaczy potwierdzono diagnozę: pododermatitis verucosa chronica obu kopyt kończyn piersiowych oraz w niewielkim stopniu w prawym kopycie kończyny miednicznej. Potwierdzeniem było wystąpienie krwawienia podczas wycinania zmienionych chorobowo struktur. Kilka dni po przyjęciu przeprowadzono zabieg na koniu stojącym, po wcześniejszej premedykacji ksylazyną i butorfanolem. Wykonano znieczulenie miejscowe nerwów dłoniowych dwóch kończyn piersiowych za pomocą podskórnej iniekcji z lidokainy w $1 / 3$ dolnej śródręcza, po stronie bocznej i przyśrodkowej. Po rozczyszczeniu kopyt przez kowala zastosowano opaskę uciskową powyżej pęciny w celu zmniejszenia krwawienia. Kolejnym krokiem było wycięcie skalpelem nieprawidłowego rozrostu strzałki gąbczastej. Analogicznie zabieg przeprowadzono na obu kończynach piersiowych. Kopyto kończyny miednicznej zostało wystrugane przez kowala, ponieważ ilość chorobowej tkanki była mniejsza i dotyczyła tylko bocznego ramienia strzałki. Bezpośrednio po zabiegu powierzchnie w miejscu wyciętej chorobowo zmienionej tkanki zostały posypane metronidazolem, następnie zastosowano opatrunki uciskowe, na które założone zostały przykręcane do podków 
podeszwy. Przez pierwsze trzy dni po zabiegu koń dostawał leki przeciwzapalne i przeciwbólowe (fluniksyna) oraz osłonę antybiotykową (prep. Shotapen) - trzykrotnie w odstępie 48 godzin. Co dwa dni zmieniane były opatrunki oraz dezynfekowano miejsca pooperacyjne. Po dwóch tygodniach od zabiegu zauważono, iż nieprawidłowa tkanka charakterystyczna dla rzekomego raka zaczyna odrastać w obu przednich kopytach. Podjęto decyzję o rozszerzeniu leczenia o doustne stosowanie glikokortykosteroidów w postaci syropu z prednisolonem. Rozpoczęto od dawki $70 \mathrm{ml}$, która stopniowo była zmniejszana w ciągu kolejnych 14 dni. Zwiększono także częstotliwość zmiany opatrunków i zmieniano je w tym czasie codziennie. Każdorazowo kopyta były moczone w preparacie dezynfekcyjnym (Virkon), następnie stosowano miejscowo metronidazol oraz spray $\mathrm{z}$ antybiotykiem (oksytetracyklina). Na tak przygotowane kopyta zakładano opatrunki uciskowe i przykręcaną podeszwę. Przez cały czas leczenia klacz nie wykazywała oznak kulawizny. Pomimo stosowanej terapii proces chorobowy nadal się rozwijał, podjęta została decyzja o kolejnym zabiegu operacyjnym. Po dwóch miesiącach od pierwszej interwencji chirurgicznej klacz została rozkuta, kopyta wystrugano.

Dwa dni później przeprowadzono kolejny zabieg, tym razem w znieczuleniu ogólnym, dzięki czemu możliwe było bardziej radykalne wycięcie zmienionych chorobowo tkanek. Po wykonaniu premedykacji przy użyciu detomidyny przeprowadzono konia do boksu wybudzeniowego i podano leki do indukcji znieczulenia ogólnego (ketamina $\mathrm{z}$ relanium). Zabieg przeprowadzono na koniu ułożonym na prawym boku. Zwierzę zaintubowano i kontynuowano znieczulenie ogólne przy użyciu isofluranu w tlenie. Zabezpieczenie przeciwbólowe zapewniono, podając butofranol i.v. podczas operacji. Wszystkie kopyta zostały rozczyszczone, dokładnie umyte i zdezynfekowane jodyną. Po wstępnej ocenie rozległości procesu chorobowego przystąpiono do usunięcia zmienionej tkanki. Użyty został do tego celu nóż pętlicowy, który umożliwił precyzyjne oddzielenie tkanki zajętej rakiem rzekomym od zdrowego tworzywa kopytowego. Najbardziej rozległy proces chorobowy dotyczył lewej przedniej kończyny i obejmował całą strzałkę (fot. 1), w prawej przedniej ograniczał się do bocznego ramienia strzałki oraz obu kątów ościenno-wsporowych (fot. 2).

W kończynach tylnych zauważono jedynie zmiany początkowe - w lewym kopycie w okolicy ramion strzałki, w prawym zaś nieprawidłowa tkanka obejmowała tylko boczne ramię. Rzekomy rak kopyta dotyka warstwy brodawkowej skóry właściwej, podczas zabiegu widoczne były charakterystyczne strzępki świadczące o obecności brodawek (fot. 1). Istotne w trakcie usuwania rzekomego raka jest, aby wyciąć w całości patologiczne tkanki. Pozostawiony nawet niewielki fragment przyczyni się do nawrotu choroby. Należy obserwować granicę pigmentowanej skóry i do tego miejsca wycinać zmienione tkanki. Po zakończeniu wycinania patologicznych struktur zastosowano miejscowo jodoform, a następnie założono opatrunki na wszystkie kopyta. Zapewniono ucisk poprzez umieszczenie zwiniętych bandaży w okolicach strzałek i zawinięcie kopyt bandażem elastycznym. Całość wzmocniono bandażami typu flex i taśmą, aby 
uniknąć przemoczenia opatrunków. Ich pierwszą zmianę zaplanowano po tygodniu od zabiegu. Przez pięć dni koń dostawał antybiotyk (penicylina ze streptomycyną). W ciągu całej terapii bardzo istotne było utrzymanie w boksie dużej ilości suchej słomy. Po tygodniu zmienione zostały opatrunki, zauważono znaczną poprawę, widoczny był narastający prawidłowy róg kopytowy. Ponieważ nie stwierdzono ponownego odrastania tkanek zajętych rakiem rzekomym, nie było konieczności ponownego wycinania. W związku z tym zastosowano miejscowo jodoform, a następnie założono opatrunki uciskowe $\mathrm{z}$ bandaży nasączonych $\mathrm{w}$ jodynie, na prawidłowo rosnący róg kopytowy użyto dziegcia.

Dwa tygodnie od zabiegu obserwowano dalszą poprawę (fot. 3), w związku z tym opatrunki na tylnych kopytach oraz prawym przednim zostały zdjęte. Założono opatrunek jedynie na lewe przednie kopyto, w którym podczas zabiegu wycięto najwięcej nieprawidłowej tkanki. W dalszych tygodniach nie nastąpił nawrót choroby i koń został wypisany do domu trzy tygodnie po drugim zabiegu.
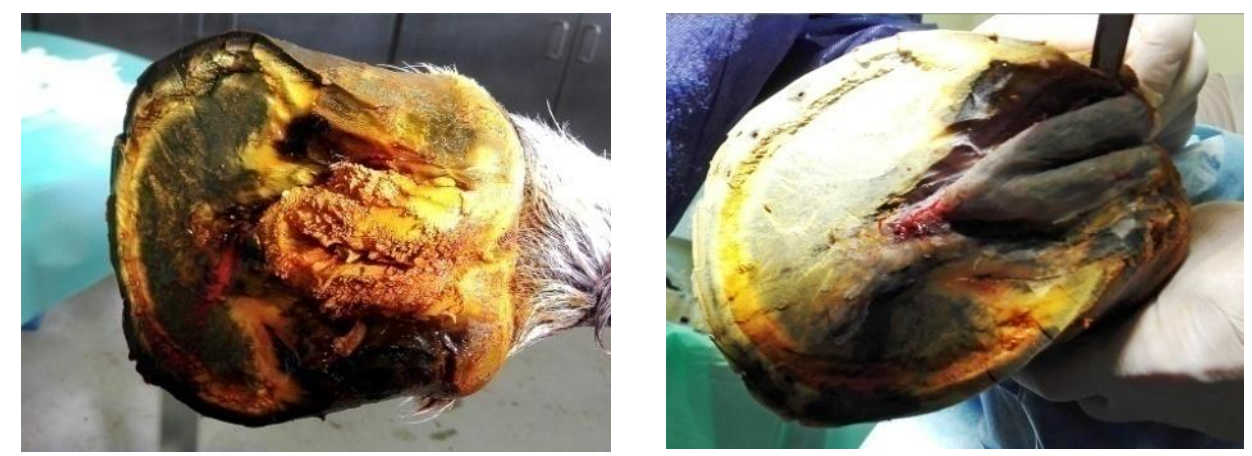

Fot. 1. Lewe przednie kopyto przed zabiegiem (po lewej) i po zabiegu (po prawej) (fot. M. Sobuś)
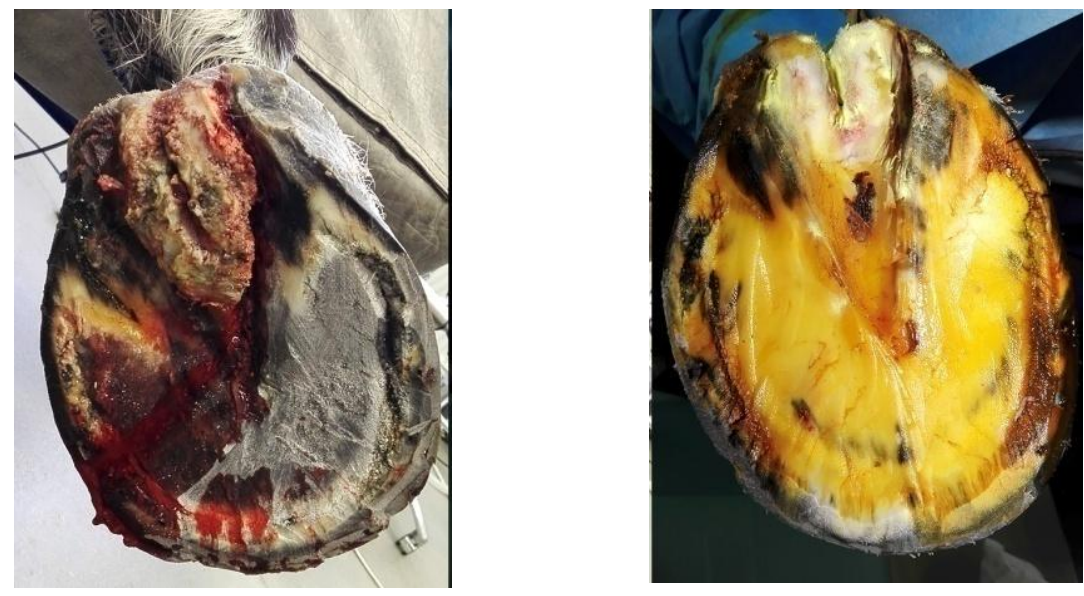

Fot. 2. Prawe przednie kopyto przed zabiegiem (po lewej) i bezpośrednio po zabiegu (po prawej) (fot. M. Sobuś) 

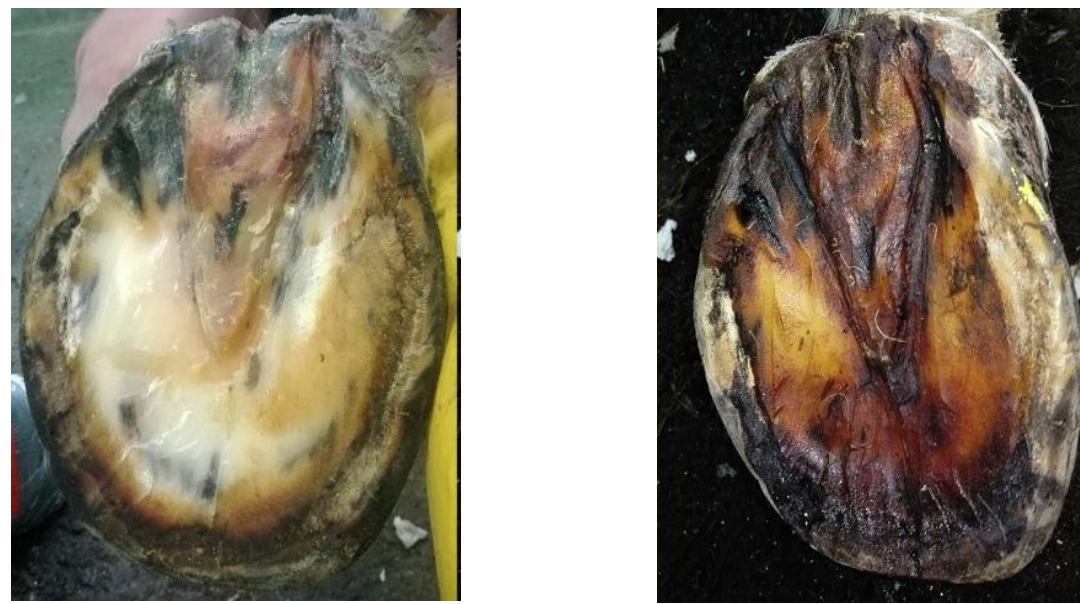

Fot. 3. Prawe przednie kopyto tydzień po zabiegu (po lewej) i dwa tygodnie po zabiegu (po prawej) (fot. M. Sobuś)

Rzekomy rak kopyta jest istotną jednostką chorobową współczesnych koni. Konie sportowe przebywające dużo czasu w boksie powinny być objęte szczególną kontrolą, ponieważ wilgoć i brak higieny mogą przyczynić się do rozwoju choroby. Nie są to jedyne czynniki predysponujące, wpływ może mieć również genetyka, a także wirusy i bakterie czy reakcja autoimmunologiczna organizmu. Warto zachować szczególną ostrożność podczas wykonywania badania kupnosprzedaż i poświęcić czas na dokładne obejrzenie kopyt. Pomimo że w wielu przypadkach rokowanie jest ostrożne, możliwe jest doprowadzanie do wyleczenia. Wymaga to jednak dokładnego i całkowitego usunięcia nieprawidłowych tkanek, regularnego zmieniania opatrunków oraz utrzymania konia w suchym i czystym środowisku. W omówionym przypadku konieczna była dwukrotna interwencja chirurgiczna oraz leczenie wspomagające. Nie jest możliwe stwierdzenie, czy taki sam efekt osiągnięto by bez podawania glikokortykosteroidów oraz regularnego dezynfekowania kopyt. Leczenie od momentu przyjazdu konia do kliniki trwało około trzech miesięcy, jednak zalecono dalsze monitorowanie stanu konia w celu obserwacji ewentualnych nawrotów choroby.

\section{Bibliografia}

Apprich V., Licka T., 2013. Equine hoof canker: a clinical trial of topical cisplatin chemiotherapy. Vet. Rec. 172(9), 238.

Apprich V., Licka T., Zipfl N., Tichy A., Gabriel C., 2017. Equine hoof canker: cell proliferation and morphology. Vet. Pathol. 54(4), 661-668.

Banic J., Skusek F., 1960. Unsere Erfahrungen in die Behandlung des Hufkrebses. Bed. Miinch. tieriirzti. Wschr. 73, 186-188.

Brandt S., Schoster A.,. Tober R., Kainzbauer C., Burgstaller J.P., Haralambus R., Steinborn R., Hinterhofer C., Stanek C., 2010. Consistent detection of bovine papillomavirus in lesions, intact 
skin and peripheral blood mononuclear cells of horses affected by hoof canker. Equine Vet. J. 43, 202-209.

Dietz O., 2006. Hufkrankheiten. W: O. Dietz, B. Huskamp (red.), Handbuch Pferdepraxis. Enke, Stuttgart, 980-983.

Fürst A.E., Lischer C.J., 2006. Degenerative and neoplastic diseases of the foot. W: Equine Surgery, 3 wyd., J.A. Auer, J.A. Stick (red.). Saunders Elsevier, St Louis, 1196-1199.

Hewes C.A., Sullins K.E., 2006. Use of cisplatin-containing biodegradable beads for treatment of cutaneous neoplasia in equidae: 59 cases (2000-2004). J. Am. Vet. Med. Assoc. 229, 1617-1622.

Jongbloets A.M., Meeus P.J., Back W., 2005. Equine exudative canker: an (auto-)immune disease? TijdschrDiergeneeskd. (4), 106-109.

Knottenbelt D.C., 2009. Injuries and diseases of the hoof. In: Knottenbelt D.C. (ed.), Pascoe's principles and practice of equine dermatology. Saunders, Elsvier, 370-371.

Mason J.H., 1962. Penicilin treatment of foot canker of the horse. J. S. Afr. Vet. Assoc. 33(2), 223-224.

Minami S., Okamoto Y., Umemura T., Sashiwa H., Saimoto H., Shigemasa Y., Matsuhashi A., 1991. A case of canker in a draft horse. Jpn. J. Equine Sci. 2, 65-70.

Oosterlinck M., Deneut K., Dumoulin M., Gasthuys F., Pille F., 2011. Retrospective study on 30 horses with chronic proliferative pododermatitis (canker). Equine Vet. Educ. 23(9), 466-471.

Redding W.R., O'Grady S., 2012. Nonseptic diseases associated with the hoof complex, Vet. Clin. Equine 28, 407-421.

Rooney J.R., Robertson J.L., 1996. Canker. In: J.R. Rooney, J.L. Robertson (eds), Equine Pathology. Iowa State University Press, Ames, 195-196.

Rowlands V., 2014. Canker - forgotten disease. Vet Times. The website for the veterinary profession, https://www.vettimes.co.uk/app/uploads/wp-post-to-pdf-enhanced-cache/1/canker-forgottendisease.pdf [dostęp: 22.10.2020].

Sherman K., Gina P.E., Brown M., 1996. Recurrent canker in a shire mare. J. Equine Vet. Sci. $16(8), 322-323$.

Stashak T.S., 2002. The foot. In: T.S. Stashak (ed.), Adam's Lameness in Horses. Lippincott Williams and Wilkins, Philadelphia, 718-719.

Théon A.P., Wilson W.D., Magdesian K.G., Pusterla N., Snyder J.R., Galuppo L.D., 2007. Longterm outcome associated with intratumoral chemotherapy with cisplatin for cutaneous tumors in equidae: 573 cases (1995-2004). J. Am. Vet. Med. Assoc. 230, 1506-1513.

Wilson DG., 1997. Equine canker. W: N.E. Robinson (red.), Current therapy in equine medicine 4. W.B. Saunders Co, Philadelphia, 127-128.

Wilson D.G., Calderwood M.M.B., Colahan P.T., 1989. Treatment of canker in horses. J. Amer. Vet. Med. Assoc. 194(12), 1721-1723. 
Kostiantyn Vasiukov ${ }^{1,3}$, Adrian Pluta ${ }^{1}$, Alina Woronowa $^{1}$, Karolina Wengerska $^{1}$, Kamil Drabik ${ }^{2}$, Justyna Batkowska ${ }^{2}$

\section{Wybrane choroby pasożytnicze drobiu}

Selected poultry parasitic diseases

Jednym z kluczowych aspektów produkcji drobiarskiej o dobrych walorach jakościowych jest zachowanie stabilnej epizootycznej sytuacji w gospodarstwie, bez względu na jego typ i wielkość. Problem występowania chorób zakaźnych w gospodarstwach jest na tyle poważny, że podlega kontroli urzędów państwowych i jednostkek podległych [Ustawa z dnia 11 marca 2004 r.].

Istnieje wiele różnych chorób o etiologii wirusowej, bakteryjnej, prionowej, które dotyczą ptaków gospodarskich, ale jednym z największych problemów są schorzenia powodowane przez organizmy prowadzące pasożytniczy tryb życia (parazytozy). Pasożyt często nie wykazuje swojej obecności, powoli i często bez widocznych objawów rozprzestrzenia się w stadzie i dopiero przy inwazji występującej na szeroką skalę można zauważyć jego obecność. Profilaktyka oraz zwalczanie parazytoz wewnętrznych jest już opanowana, ale zdecydowanie większy problem stanowią parazytozy zewnętrzne, gdyż niewiele jest preparatów np. przeciwko kleszczom, wszołom czy wszom, które nie stanowiłyby jednocześnie zagrożenia dla ludzi, ptaków oraz środowiska zewnętrznego.

Klasyfikując parazytozy, wyznaczono podział ze względu na przyczynę inwazji: stawonogi (roztocze i owady), helmintozy (nicienie, przywry, tasiemce, kolcogłowy) oraz choroby wywołane przez pierwotniaki [Mazurkiewicz i in. 2019]. W niniejszej pracy przyjęto podział na parazytozy wewnętrzne i zewnętrzne oraz opisano wybrane $\mathrm{z}$ nich.

\section{Wybrane choroby drobiu powodowane przez pasożyty wewnętrzne}

\section{Kokcydioza drobiu}

Kokcydioza dotyczy wielu gatunków zwierząt gospodarskich, w tym drobiu. Najczęściej chorują kury, rzadziej indyki czy kaczki. Szczególnie wrażliwe są

\footnotetext{
${ }^{1}$ Uniwersytet Przyrodniczy w Lublinie, Studenckie Koło Naukowe Biologii, Hodowli i Użytkowania Drobiu (Studenckie Koło Naukowe działa pod patronatem Krajowej Rady Drobiarstwa)

${ }^{2}$ Uniwersytet Przyrodniczy w Lublinie, Instytut Biologicznych Podstaw Produkcji Zwierzęcej

3 vasiukovk@gmail.com
} 
osobniki młode. Chorobę wywołują pierwotniaki z rodzaju Eimeria spp., które są obecnie największym problemem współczesnego drobiarstwa [Allen i Fetterer 2002, Tewari i Maharana 2011]. Są to pasożyty wewnątrzkomórkowe bytujące w jelitach ptaków, przy czym różne gatunki zasiedlają różne odcinki jelit. Występuje 5 rodzajów kokcydiozy wywoływanej przez 5 gatunków pasożytów drobiu grzebiącego: E. tenella, E. necatrix, E. brunetii, E. acervulina oraz E. Maxima [Antonik i in. 2008]. Dzięki tej wiedzy diagnostyka kokcydiozy może opierać się również na badaniu zmian występujących w poszczególnych częściach przewodu pokarmowego. Przebieg inwazji oraz jego skutki są uzależnione od stanu fizjologicznego ptaków, ich wieku i kondycji oraz odporności, jak również gatunku Eimerii. W przypadku występowania choroby w formie klinicznej stwierdza się znaczny wzrost upadków ptaków w stadzie oraz krwawą biegunkę. Forma podkliniczna wpływa na ograniczenie pobierania paszy, co skutkuje obniżeniem przyrostów masy ciała [Gaweł i in. 2015].

Rozpowszechnieniu się kokcydii sprzyja bezpośrednio kontakt pomiędzy osobnikiem zdrowym a ściółką czy pomiotem, paszą czy wodą zanieczyszczonymi odchodami ptaków chorych. Oprócz zjadliwości kokcydia charakteryzują się również wysoką przeżywalnością w środowisku zewnętrznym, w glebie mogą przetrwać rok. Wektorem choroby może być także człowiek, gryzonie oraz ptaki wolno żyjące.

Najbardziej znanym sposobem zwalczania Eimerii spp. jest stosowanie antybiotyków jonoforowych jako kokcydiostatyków, na ogół jako dodatku do paszy pełnoporcjowej. Cechą negatywną tych środków jest tendencja do pozostawania w tkankach ptaków przez 7 dni od podania. Pozostałości tych leków w organizmie ptaków mogą stwarzać zagrożenie dla zdrowia konsumenta, stąd konieczne jest zachowanie okresu karencji. Oprócz kokcydiostatyków popularne jest stosowanie szczepień, by zapobiec kokcydiozie [Sharman i in. 2010].

\section{Askaridioza}

Parazytoza ta jest wywoływana przez nicienie Ascaridia galli, które bytują w jelicie cienkim ptaków. Chorują przede wszystkim osobniki młode, ale również ptaki dorosłe: kury, perlice, bażanty, nieco rzadziej indyki. Do zarażenia dochodzi zwykle poprzez połknięcie oocyst. W zależności od skali inwazji, a także wieku i stanu fizjologicznego stada, nasilają się objawy oraz skutki choroby [Tongor i McGraw 1967]. Te pasożyty powodują wycieńczenie organizmu oraz zahamowanie wzrostu, dochodzi również do zakłócenia procesów trawienia, funkcjonowania wątroby oraz wchłaniania składników odżywczych w jelitach. W przypadku bardziej zaawansowanej postaci pojawia się paraliż nóg [Ramadan i Znada 1991] czy zatrucie organizmu wydalinami pasożytów. Gdy inwazja mocno się nasila (również gdy dochodzi do autoinwazji) wzrasta liczba upadków w stadzie na skutek wyniszczenia organizmów osobników zarażonych oraz oddziaływanie fizyczne nicieni na ciało żywiciela (zatkanie światła jelit, perforacja ściany przewodu 
pokarmowego). U kur niosek inwazja A. galli może powodować spadek nieśności, a u kurcząt brojlerów obniżać jakość mięsa.

Niektóre badania wykazują oddziaływanie różnych związków chemicznych, np. soli zasadowych miedzi czy organicznych związków manganu na nicienie A. galli. Zaleca się ich dodatek do paszy jako element profilaktyki askaridiozy [Teodorova i Gabrashanska 2002]. Występowanie i nasilenie inwazji A. galli jest istotnie uzależnione od systemu chowu drobiu, przy czym większe zagrożenie odnotowano w przypadku utrzymywania ptaków ekstensywnie [Thapa i in. 2015]. Obecność nicieni zarejestrowano nawet u $100 \%$ ptaków. Z kolei w przypadku chowu intensywnego, w którym ptaki nie mają kontaktu ze środowiskiem zewnętrznym, obecność nicienia jest odnotowana u około $25 \%$ osobników [Eigaard i in. 2006].

\section{Histomonadoza}

Ta choroba często jest określana jako „czarnogłówka”. Wiciowiec Histomonas meleagridis przenoszony jest za pośrednictwem dżdżownic lub nicienia Heterakis gallinarum (heterakidoza), w jajach którego może przetrwać lata. Chorują przede wszystkim indyki, bażanty oraz kuropatwy. Jest bardzo dużym problemem w hodowli zagrodowej cietrzewi, powodując ogromne straty i upadki w stadach ptaków [Kiełczyński 2016]. Kury mogą być wyłącznie nosicielami pasożyta, a drób wodny wykazuje wysoką odporność na działanie wiciowca. Ptaki z reguły zarażają się jeszcze w młodym wieku, a w przypadku ustąpienia objawów klinicznych taki osobnik staje się nosicielem pasożyta. Do zakażenia czarnogłówką dochodzi drogą per os przy połknięciu jaj. Później pierwotniak niszczy błonę śluzową w jelitach ślepych ptaka, skąd trafia $\mathrm{z}$ krwiobiegiem do poszczególnych narządów gospodarza. Uszkadza przede wszystkim wątrobę, w której zaczyna się pojawiać martwica. W jelitach ślepych wiciowiec powoduje stany zapalne i obrzęki.

Zagrożeniem jest również środowisko, w którym występuje pasożyt. W glebie H. meleagridis może przetrwać kilka lat, odchody ptaków - nosicieli, którymi jest zanieczyszczona pasza czy woda, również są wektorem zakażenia. Badania wykazały, że pasożyt nie wytrzymuje oddziaływania niektórych temperatur: $18-22^{\circ} \mathrm{C}$ w ciągu $48 \mathrm{~h}$ lub $5^{\circ} \mathrm{C}$ w ciągu $24 \mathrm{~h}$ [Bishop 1938]. W ubiegłym stuleciu choroba była mocno ograniczona $\mathrm{z}$ uwagi na stosowanie nitroimidazoli i nitrofuranu, obecnie zakazanych, co zmusza do poszukiwania alternatywnych metod walki z tym pierwotniakiem [Hauck i Hafez 2012]. Wykazano pozytywne działanie paromomycyny na Histomonas meleagridis. Ten antybiotyk niszczy organizmy pasożytnicze, wykazuje działanie osłonowe i regenerujące w stosunku do wątroby oraz nie zmniejsza przyrostów masy ciała ptaków [Hess i in. 2015]. Problem występowania histomonadozy jednak ciągle rośnie, nie uzyskano również pozytywnych wyników w profilaktyce choroby za pomocą preparatów pochodzenia roślinnego [Koncicki $\mathrm{i}$ in. 2006]. 


\section{Wybrane choroby drobiu powodowane przez pasożyty zewnętrzne}

\section{Wszołowica}

Wszoły to pasożyty nazywane również ptasimi wszami. Występuje ok. 2600 gatunków podrzędu Mallophaga, $11 \mathrm{z}$ nich bytuje na kurach domowych [Prelezov i Koinarski 2006]. Wszoły powodują obniżenie produkcyjności ptaków, podrażnienia skóry, utratę apetytu, a w zależności od skali inwazji - zahamowanie wzrostu i rozwoju, a nawet śmierć [Fabiyi 1996]. Żywią się piórami, krwią i nabłonkiem zaatakowanego osobnika. Oprócz objawów zewnętrznych, takich jak zaczerwienienie skóry, rany i krwotoki, obecne są też pewne zmiany patomorfologiczne, które dotyczą śledziony, wątroby, płuc, nerek i jelit. Może dochodzić też do zatrucia tkanek mięśniowych [Prelezov i in. 2006, Naz i in. 2011]. Za najbardziej patogenne gatunki podrzędu Mallophaga uznaje się Menacanthus stramineus i Menacanthusc ornutus, powodujące silną niedokrwistość i śmiertelność drobiu [Sychra i in. 2008]. Wszoły mogą również stanowić zoonozę. Dodatkowo pasożyty te mogą przenosić patogeny niebezpieczne dla drobiu i człowieka, m.in. Escherichia coli, Salmonella, Toxoplasma gondii [Boczek i Pruszyński 2015]. Oprócz kwarantanny ptaków nowo włączanych do stada, a także dezynfekcji wyposażenia budynków inwentarskich w zwalczaniu wszołowicy drobiu stosuje się chemiczne insektycydy zawierające jako substancję aktywną m.in. karbaryl, pyretrum, permetrynę i inne pyretroidy, chlorpyrifos, fipronil, imidakloprid. Decyzje co do wyboru preparatu powinien podjąć lekarz weterynarii.

\section{Ptaszyniec kurzy (czerwony kleszcz) Dermanyssus gallinae}

Inwazje ptaszyńca są ogromnym problemem współczesnego drobiarstwa, dochodzi bowiem do znacznych strat w produkcji wielkotowarowej. Roztocza stanowią zagrożenie nie tylko dla ptaków, ale także dla ludzi. Istnieje też inne, pośrednie zagrożenie dla człowieka, ze względu na pozostałości preparatów, akarycydów, używanych do zwalczania pasożytów.

Do zakażenia ptaszyńcem dochodzi na skutek kontaktu osobników chorych i zdrowych, przy transporcie ptaków oraz poprzez sprzęt drobiarski. Wektorem może być również człowiek, gryzonie oraz ptaki dzikie. W trakcie inwazji D. gallinae dochodzi do ogólnego osłabienia organizmu niosek, występuje chroniczny stres, podrażnienie, zwiększa się szansa pojawienia się kanibalizmu. Przez utratę krwi oraz intoksykację powoli rozwija się anemia, co jest dobrze zauważalne przy oglądaniu grzebienia, dzwonków i ogólnie głowy, która przybiera blady kolor, spada też odporność. Pasożyt namnaża się z ogromną szybkością, co trudno kontrolować [Sokół i Romaniuk 2007, Koziałek i Sokół 2015]. Najgorszym okresem jest lato, gdyż $D$. gallinae świetnie bytuje w warunkach podwyższonej temperatury oraz niskiej wilgotności, co może stanowić szczególny problem w ekstensywnym chowie drobiu [De Luna i in. 2008]. Nasilająca się inwazja ptaszyńca może powodować obniżenie nieśności (15-20\%), a nawet śmiertelność (6-8\%). 
Ptaszyniec zasiedla różne miejsca w kurniku (klatki, gniazda, karmidła, rury wodociągów), a aktywność wykazuje w nocy. Kilpinen i in. [2005] podają, że nioski, wyczuwając obecność roztoczy, czują niepokój. Starają się omijać miejsca w kurniku, w których zostały zaatakowane. Intensyfikacji ulegają także zachowania higieniczne ptaków, które dużo czasu spędzają, czyszcząc pióra. Kowalski i in. [2006] wykazali wzrost poziomu kortykosteronu w surowicy krwi kur niosek z uwagi na inwazję ptaszyńca.

Zwalczanie czerwonego kleszcza jest dość trudne, a często stosowany do tego fipronil jest groźnym dla ludzi i ptaków środkiem chemicznym. Metabolit fipronilu jest związkiem wykrywalnym w surowcach zwierzęcych: jajach, mięsie czy mleku. Stafford i in. [2018] podają, że zarówno u owadów pasożytniczych, jak i u ludzi fipronil uszkadza system nerwowy, wywołując nadpobudzenie. Nawet jego niskie dawki mogą doprowadzać do uszkodzenia mitochondriów, zaburzenia fosforylacji, co w wyniku końcowym prowadzi do śmierci komórki. Poszukuje się alternatywnych metod walki z inwazjami ptaszyńca na fermach drobiu. Chirico i Tauson [2002] wspominają o stosowaniu pułapek $\mathrm{z}$ drewna w postaci skrzynek, ale wytworzenie i instalacja tego rodzaju narzędzi wiąże się z dodatkowymi nakładami finansowymi. Jedyną alternatywną metodą, której skuteczności dowiedziono doświadczalnie, jest stosowanie specjalnego programu świetlnego, w którym na $1 / 4$ godziny światła przypada $3 / 4$ godziny ciemności [Zoons 2004]. Jednak z późniejszych doniesień wynika, że pozytywny efekt tej metody zanika po pewnym czasie [Mul i in. 2009]. W aspekcie zwalczania czerwonego kleszcza nadzieję pokłada się w preparatach pochodzenia roślinnego (olejki eteryczne, ekstrakty roślinne, napary itp.), w tym też jako dodatków do paszy, które są wytwarzane z różnych części roślin (łodygi, pędy, liście czy kwiatostany) [Masoumi i in. 2016].

Tematyka występowania, zwalczania i profilaktyki zakażeń dotycząca omawianych gatunków pasożytów jest stale aktualna ze względu na ich łatwość w namnażaniu się, szybkie dostosowywanie się do warunków środowiskowych i sposobów ich zwalczania. Zatem należy ciągle monitorować ewentualne zmiany $\mathrm{w}$ funkcjonowaniu wybranych pasożytów drobiu i odpowiednio reagować w celu zachowania równowagi pomiędzy skutecznością prowadzenia produkcji a bezpieczeństwem konsumenta oraz dobrostanem zwierząt gospodarskich.

\section{Bibliografia}

Allen P.C., Fetterer R.H., 2002. Recent advances in biology and immunobiology of Eimeria species and in diagnosis and control of infection with these coccidian parasites of poultry. Clin. Microbiol. Rev. 15(1), 58-65. https://doi.org/10.1128/CMR.15.1.58-65.2002

Antonik S., Okulewicz A., Gaweł A., Mazurkiewicz M., 2008. Występowanie gatunków Eimeria u kur na terenie Dolnego Śląska. Med.Weter. 64, 886-888.

Bishop A., 1938. Histomonas meleagridis in domestic fowls (Gallus gallus). Cultivation and experimental infection. Parasitol. 30(02), 181-194. https://doi.org/10.1017/S0031182000025749 
Boczek J., Pruszyński G., 2015. Owady niebezpieczne dla zdrowia oraz życia człowieka i zwierząt domowych. Zag. Doradz. Rol., 107-120.

Chirico J., Tauson R., 2002. Traps containing acaricides for the control of Dermanyssus gallinae. Vet. Parasitol. 110(1), 109-116. https://doi.org/10.1016/S0304-4017(02)00310-2

De Luna C.J., Arkle S., Harrington D., George D.R., Guy J.H., Sparagano O.A., 2008. The poultry red mite Dermanyssus gallinae as a potential carrier of vector-borne diseases. Ann. N. Y. Acad. Sci. 1149(1), 255-258. https://doi.org/10.1196/annals.1428.085

Eigaard N.M., Schou T.W., Permin A., Christensen J.P., Ekstrøm C.T., Ambrosini F., Cianci D., Bisgaard M., 2006. Infection and excretion of Salmonella enteritidis in two different chicken lines with concurrent Ascaridia galli infection. Avian Pathol. 35(6), 487-493. https://doi.org/ 10.1080/03079450601071696

Fabiyi J.P., 1996. Association between duration of humid season and geographical distribution patterns of different species of chewing lice (Mallophaga: Insecta) infesting domestic chickens in Nigeria. J. Parasitol. 82(6), 1034-1036. https://doi.org/10.2307/3284220

Gaweł A., Bobusia K., Bobrek K., 2015. Identyfikacja gatunków Eimeria spp. występujących u kur i kurcząt brojlerów na terenie Polski. Med.Weter. 71(6), 382-385.

Hauck R., Hafez H.M., 2012. Experimental infections with the protozoan parasite Histomonas meleagridis: a review. Parasitol. Res. 112(1), 19-34. https://doi.org/10.1007/s00436-0123190-5

Hess M., Liebhart D., Bilic I., Ganas P., 2015. Histomonas meleagridis - new insights into an old pathogen. Vet. Parasitol. 208 (1-2), 67-76. https://doi.org/10.1016/j.vetpar.2014.12.018

Kiełczyński C., 2016. Przyczyny chorób i upadków cietrzewi (Tetraotetrix Linnaeus, 1758) w hodowli wolierowej w OHZ Parzęczewo. Zarządzanie Ochroną Przyrody w Lasach 10, 101-109. https://doi.org/10.5604/01.3001.0010.0500

Kilpinen O., Roepstorff A., Permin A., Nørgaard-Nielsen G., Lawson L.G., Simonsen H.B., 2005. Influence of Dermanyssus gallinae and Ascaridia galli infections on behaviour and health of laying hens (Gallus gallus domesticus). Br. Poult. Sci. 46(1), 26-34. https://doi.org/10.1080/ 00071660400023839

Koncicki A., Bukowska A., Mazur-Gonkowska B., Krasnodebska-Depta A., Stenzel T., 2006. Ocena skutecznosci kwasu 4-nitrofenyloarsenowego w profilaktyce inwazji Histomonas meleagridis u indyków. Med. Weter. 62(10), 1191-1194.

Kowalski A., Sokół R., Jedlińska-Krakowska M., 2006. Wpływ inwazji ptaszyńca Dermanyssus gallinae na poziom kortykosteronu oraz wskaźników immunologicznych i hematologicznych u kur niosek. Med. Weter. 62(10), 1188-1190.

Koziałek S., Sokół R., 2015. Dermanyssus gallinae still poses a serious threat for the rearing of laying hens. Pol. J. Nat. Sci. 30(4), 451-463.

Masoumi F., Youssefi M.R, Tabari M.A., 2016. Combination of carvacrol and thymol against the poultry red mite (Dermanyssus gallinae). J. Parasitol. Res. 115(11), 4239-4243. https://doi.org/10.1007/s00436-016-5201-4

Mazurkiewicz M., Gaweł A., Bobrek K., 2019. Choroby pasożytnicze wywoływane przez pierwotniaki. W: M. Mazurkiewicz, A. Wieliczko (red.), Choroby drobiu. Wrocław, 667-684.

Mul M., Niekerk T.V., Chirico J., Maurer V., Kilpinen O., Sparagano O., Thind B., Zoons J., Moore D., Bell B., Gjevre A.G., Chauve C., 2009. Control methods for Dermanyssus gallinae in systems for laying hens: results of an international seminar. Worlds Poult. Sci. J. 65(04), 589-600. https://doi.org/10.1017/S0043933909000403

Naz S., Rizvi S.A., Akhter M.A., 2011. Records of ghewing lice (Phthiraptera) on different birds of Phasianidae (Galliformes) from Sindh-Pakistan. Pak. Entomol. 26(2), 153-156.

Prelezov P.N., Groseva N.I., Goundasheva D.I., 2006. Pathomorphological changes in the tissues of chickens, experimentally infected with biting lice (Insecta: Phthiraptera). Vet. Arh. 76(3), 207-215.

Prelezov P.N., Koinarski V.T.S., 2006. Species variety and population structure of mallophaga (insecta: Phthiraptera) on chickens in the region of Stara Zagora. Bulg. J. Vet. Med. 9(3), 193-200. 
Ramadan H.H., Znada N.Y.A., 1991. Some pathological and biochemical studies on experimental ascaridiasis in chickens. Food/Nahrung 35(1), 71-84. https://doi.org/10.1002/ food. 19910350120

Sharman P.A., Smith N.C., Wallach M.G., Katrib M., 2010. Chasing the golden egg: vaccination against poultry coccidiosis. Parasite Immunol. 32(8), 590-598. https://doi.org/10.1111/j.13653024.2010.01209.x

Sokół R., Romaniuk K., 2007. Przebieg i dynamika inwazji Dermanyssus gallinae w fermie kur niosek. Med. Weter. 63(4), 484-485.

Stafford E.G., Tell L.A., Lin Z., Davis J.L., Vickroy T.W., Riviere J.E., Baynes R.E., 2018. Consequences of fipronil exposure in egg-laying hens. J. Am. Vet. Med. Assoc. 253(1), 57-60. https://doi.org/10.2460/javma.253.1.57

Sychra O., Harmat P., Literák, I., 2008. Chewing lice (Phthiraptera) on chickens (Gallus gallus) from small backyard flocks in the eastern part of the Czech Republic. Vet. Parasitol. 152(3-4), 344-348. https://doi.org/10.1016/j.vetpar.2008.01.001.

Teodorova S.E., Gabrashanska M., 2002. Optimal treatment of Ascaridia galli infected chickens with salts of trace elements and a kinetic model for chicken growth. J. Helminthol. 76, 79-85. https://doi.org/10.1079/JOH200189

Tewari A.K., Maharana B.R., 2011. Control of poultry coccidiosis: changing trends. J.Parasit. Dis 35(1), 10-17. https://doi.org/10.1007/s12639-011-0034-7

Thapa S., Hinrichsenb L.K., Brenninkmeyer C., Gunnarssond S., Heerkens J.L.T., Verwer C., Niebuhr K., Willett A., Grillii G., Thamsborga S.M., Sørensenb J.T., Mejer H., 2015. Prevalence and magnitude of helminth infections in organic laying hens (Gallus gallus domesticus) across Europe. Vet. Parasitol. 214, 118-124. https://doi.org/10.1016/j.vetpar.2015.10.009

Tongor M.S., McGraw B.M., 1967. Experimental Ascaridiasis: influence of chicken age and infective egg dose on structure of Ascaridia galli populations. Exp. Parasitol. 21, 160-172. https://doi.org/10.1016/0014-4894(67)90078-1

Ustawa z dnia 11 marca 2004 r. o ochronie zdrowia zwierząt oraz zwalczaniu chorób zakaźnych zwierząt, Dz.U. $2004 \mathrm{nr} 69$ poz. 625.

Zoons J., 2004. The effect of light programs on red mite (Dermanyssus gallinae) in battery cage housing. W: G.C. Perry (red.), Welfare of the laying hen. CABI Publishing, 416 
Anna Wiśniewska ${ }^{1,2}$, Katarzyna Strzelec ${ }^{1}$, Martyna Frątczak ${ }^{1}$

\title{
Porównanie zmian w częstości pracy serca koni użytkowanych przez jednego i wielu jeźdźców
}

Comparison of changes in heart rate of horses exploited by one and many riders

\begin{abstract}
Wstęp
Człowiek udomowił konia i nauczył się użytkować go na wiele różnych sposobów, ale przy tym poważnie zmienił jego otoczenie i naraził go na działanie różnych nowych bodźców [Mills i in. 2005]. Koniom zaczęto stawiać nowe wyzwania, wymagające od nich nie tylko siły fizycznej, ale również odporności psychicznej i zdolności do szybkiej adaptacji [McBride i Mills 2012].

Praktycznie każdy rodzaj użytkowania koni jest dla nich poważnie obciążający fizycznie i psychicznie [Burn i in. 2010]. Często rozwój możliwości sportowych lub nadmierne użytkowanie $\mathrm{w}$ monotonnej rekreacji nie idzie $\mathrm{w}$ parze $z$ dobrostanem [Ikinger i in. 2016]. Zwłaszcza pojawiające się wówczas duże obciążenie psychiczne tych zwierząt może być czynnikiem hamującym ich prawidłowy rozwój. Z kolei wymuszanie nieuzasadnionego realnymi potrzebami treningowymi nadmiernego wysiłku może bardzo negatywnie odbić się na naturalnych procesach adaptacji organizmu [Visser i Van Wijk-Jansen 2012]. Dostrzegając te problemy, coraz częściej szuka się doskonalszych, czyli zgodnych z naturą, psychiką i rozwojem osobnika, metod szkolenia oraz racjonalnego użytkowania koni. Wzajemna interakcja predyspozycji genetycznych i oddziaływania otoczenia warunkuje prawidłowe odczucia emocjonalne, a co za tym idzie pożądane przez człowieka zachowanie się konia [Bürger i Zietzschmann 2010].

Sposób zachowania się zwierzęcia jest wynikiem m.in. odbierania przez zmysły bodźców z otoczenia [Eilam i Trop 2012]. Odbierane bodźce, przetwarzane przez układ nerwowy, mają istotny wpływ na reakcje behawioralne i w dużym stopniu warunkują stan emocjonalny. Działanie negatywnych bodźców, zwanych stresorami, przyczynia się do zaburzenia emocjonalnego organizmu, wywołując stan zwany zachwianiem równowagi psychicznej, w konsekwencji prowadzący do pojawienia się stresu [Hall i in. 2013].
\end{abstract}

\footnotetext{
${ }^{1}$ Uniwersytet Przyrodniczy w Lublinie, Wydział Nauk o Zwierzętach i Biogospodarki Katedra Hodowli i Użytkowania Koni

${ }^{2}$ anna.wisniewska@up.lublin.pl
} 
Reakcja emocjonalna zazwyczaj jest gwałtowna, ale krótkotrwała, przez co organizm potrafi przystosować się do niej bez trwałych, niekorzystnych zmian [Roelofs $\mathrm{i}$ in. 2016]. Jeśli reakcja ta trwa dłużej, może spowodować dyskomfort zarówno psychiczny, jak i fizyczny, co prowadzi do powstania zmęczenia organizmu, a nawet jego wyczerpania, czyli zespołu objawów opisywanych jako stres.

Jednakże tego typu reakcje mogą mieć również pozytywne aspekty, przez co są wykorzystywane do wywoływania właściwej reakcji alarmowej na niebezpieczeństwo [Valenchon i in. 2017]. Zarówno ucieczka może być taką reakcją, jak również adaptacja do warunków środowiska [Rollin 2011]. Należy pamiętać, że stres korzystny jest jedynie wtedy, gdy siła i czas jego działania nie przekroczą granic wytrzymałości osobniczej organizmu [Young i in. 2012]. Stres jest w większości przypadków niekorzystny dla zwierząt. Wywołuje zaburzenia równowagi organizmu i stany napięcia, co może prowadzić do wystąpienia wielu procesów patologicznych [Tsuzuki i in 2016]. Każdy osobnik ma inną wrażliwość osobniczą i w inny sposób reaguje na stres. Nie bez znaczenia jest w tym przypadku wiele czynników, w tym rasa, wiek i płeć, ale również charakter, temperament i kondycja [Valera i in. 2012]. Mimo iż na podstawie przyczyn powstawania potrafimy dość precyzyjnie rozróżnić rodzaje stresu, to najczęściej jednak wskazuje się na stres wieloprzyczynowy (polietiologiczny), który obrazuje się m.in. zaburzeniami pobudliwości emocjonalnej, począwszy od jej wybujałości, a skończywszy na zobojętnieniu.

Konie użytkowane sportowo i rekreacyjnie zazwyczaj narażone są na stres złożony z kilku komponentów: stres manipulacyjny, stres wysiłkowy i stres emocjonalny, przy czym prawdopodobnie to ten ostatni jest najgroźniejszy z powodu działania specyficznych mechanizmów fizjologicznych [Ikinger i in. 2016].

Bardzo często spotykanym stresorem u koni jest monotonny lub nadmiernie intensywny trening sportowy [Bartolomé i Cockram 2016] czy też samo wdrażanie do treningu młodego konia [Kędzierski i Janczarek 2009]. Większość koni reaguje na stres podenerwowaniem i widocznym napięciem mięśniowym [Hall $i$ in. 2014]. Napięcie powoduje, że ciało konia usztywnia się, staje się nieelastyczne, a jego kroki są krótkie i nieregularne. Innym objawem doznawanego napięcia jest nadpobudliwość, agresja albo wręcz odwrotnie: apatia czy brak motywacji. Częstym stresorem u koni jest też strach, ból bądź obawa przed bólem, który wcześniej występował [Albinson 2012].

Innymi skutkami stresu są zaburzenia zachowania się koni [Sarrafchi i Blokhuis 2013]. Zaburzenia behawioralne związane $\mathrm{z}$ chwilowym czynnikiem stresogennym zazwyczaj mijają wraz z ustaniem działania bodźca. Zaburzenia emocjonalne powodowane stresem psychicznym uzewnętrzniają się poprzez nietypowe i nieprawidłowe zachowanie. Przykładem takiego zachowania są stereotypie, czyli proste czynności, pozbawione rzeczywistego celu i niemające związku z zaspokojeniem potrzeb organizmu, wykonywane przez zwierzę najczęściej w formie rytmicznej. Te czynności występują w różnych formach i w różnym natężeniu [Ijichi i in. 2013]. Odnotowuje się u koni również szeroko rozumiane nerwice. 
Mają za podstawę agresję i strach, a objawiają się wzmożonym pobudzeniem emocjonalnym oraz reaktywnością zwierzęcia [Kirsty i in. 2015].

Podstawowym wskaźnikiem oceny pobudliwości emocjonalnej konia jest częstość pracy serca (HR) [Janczarek i in. 2016]. Parametr ten jest też bardzo pomocny w ocenie wydolności i reakcji organizmu na wysiłek. Badany w spoczynku jest także podstawowym wskaźnikiem charakteryzującym stan emocjonalny koni [Stachurska i in. 2015].

Odpowiednio wytrenowany i prawidłowo użytkowany koń powinien pod koniec treningu uzyskać wartość HR nieprzekraczającą 64 uderzeń na minutę. Podwyższone wartości HR wskazują na nadmierny wysiłek, co może przełożyć się na wiele zaburzeń metabolicznych, skutkujących wysokim, niemiarowym lub skaczącym HR i wieloma innymi problemami fizjologicznymi [Goachet i in. 2010].

Coraz częściej wykorzystywanym parametrem w ocenie pobudliwości emocjonalnej koni jest też zmienność HR, określana na podstawie czasu upływającego pomiędzy kolejnymi załamkami R na krzywej EKG [Schmidt i in. 2010]. Analiza taka jest bardziej precyzyjna i znacznie ułatwia wychwytywanie nieprawidłowości występujących $\mathrm{w}$ rytmie pracy serca. Obecnie coraz częściej stosuje się kontrolę emocji i wytrenowania koni z równoczesnym użyciem kilku wskaźników pracy serca [Janczarek i in. 2013].

Kontrolę i doskonalenie cech użytkowych koni opiera się w znacznej mierze na nowoczesnych metodach diagnostycznych [McGowan i Hyytiäinen 2017, Vincze i in. 2017]. Fakt ten jest związany z dynamicznym rozwojem sportów konnych, co pociąga za sobą szybki rozwój wiedzy o fizjologii wysiłku konia. Wiedza ta ułatwia wykorzystanie wskaźników zarówno fizjologicznych, jak i klinicznych do przeprowadzania precyzyjnej oceny wydolności fizycznej zwierząt oraz ich zdolności adaptacji do rosnących obciążeń [Liou i in. 2016]. Nie bez znaczenia pozostaje tu również dbałość o właściwy stan psychiczny użytkowanych koni [McBride i Mills 2012].

W pracy założono, że liczba jeźdźców dosiadających konie ma istotny wpływ na pobudliwość emocjonalną tych zwierząt, przy czym najmniejszej pobudliwości można spodziewać się w przypadku koni dosiadanych przez jedną lub najwyżej dwie osoby. W związku z tym celem pracy była porównawcza analiza częstości pracy serca koni dosiadanych przez różną liczbę jeźdźców.

\section{Badania własne i dyskusja}

Badaniami objęto 30 koni wierzchowych, w tym wałachy i klacze różnych ras (głównie ras: małopolskiej, wielkopolskiej i polski koń szlachetny półkrwi), w wieku 8-15 lat. Materiał podzielono na 3 grupy z uwzględnieniem liczby osób dosiadających konie: I - konie dosiadane przez małą liczbę jeźdźców (1-2 osoby), II - konie dosiadane przez średnią liczbę jeźdźców (3-5 osób), III - konie dosiadane przez dużą liczbę jeźdźców (ponad 5 osób). Wszystkie konie były 
użytkowane w sporcie (głównie z I i II grupy) lub rekreacji (z III grupy) przez 6 dni w tygodniu, wykonując pracę o średnim natężeniu. Czas pracy w każdym dniu nie przekraczał 3 godzin.

Badania polegały na rejestracji HR podczas przygotowania do pracy (czas pomiaru $15 \mathrm{~min}$ ), HR wysiłkowego (w trakcie jednakowej, trwającej $60 \mathrm{~min}$ pracy pod siodłem w stępie, kłusie i galopie) oraz HR powysiłkowego (po zakończonej pracy, czas pomiaru $15 \mathrm{~min}$ ).

Zapis HR przeprowadzano z użyciem specjalistycznych telemetrycznych urządzeń produkcji fińskiej firmy Polar (typ RS800 CX), składających się z zakładanej na konia elektrody (T 61 - CODED), rejestrującej impulsy kurczącego się serca i z mikroprocesorowego rejestratora $\mathrm{z}$ bezprzewodowym zapisem danych.

Zwilżoną żelem do USG elektrodę umieszczano za pomocą elastycznej opaski na wysokości serca, $\mathrm{z}$ lewej strony klatki piersiowej, w miejscu popręgu. Pozyskane dane przeniesiono $\mathrm{z}$ odbiornika na dysk komputera $\mathrm{z}$ wykorzystaniem urządzenia peryferyjnego typu IrDA. Analizę danych wykonano w programie Polar ProTrainer 4.0.

Zebrane wyniki poddano obróbce statystycznej w programie Statistica 6.0, wykonano wieloczynnikową analizę wariancji z uwzględnieniem grupy badawczej, kolejnego pomiaru i rodzaju użytkowania koni. Wyniki objęły wartości średnie i ekstremalne oraz odchylenie standardowe. Za pomocą testu Tukeya określono istotności różnic między średnimi.

W tabeli 1 przedstawiono statystyczną charakterystykę częstości pracy serca przed wysiłkiem dla każdej z trzech badanych grup. Stwierdzono, iż średnie HR wynosiło 40-60 ud./min, a jego wartość była najniższa w grupie III, czyli w przypadku koni dosiadanych przez dużą liczbę osób. Wartość najwyższa wystąpiła natomiast u koni dosiadanych przez 3-5 osób. W badaniach Kapronia i in. [1997] prowadzonych na koniach startujących w dyscyplinie WKKW poziom HR spoczynkowego zawierał się w granicach od 27,4 ud./min do 38,88 ud./min. Wartości te były jednak odczytane podczas ciszy stajennej, a nie w trakcie przygotowania konia do jazdy. Z kolei w badaniach Pietrzaka i in. [2004] dotyczących rocznych i dwuletnich koni małopolskich wysokość średniego HR w spoczynku przekraczała poziom $100 \mathrm{ud}$./min, co może świadczyć o silnym pobudzeniu emocjonalnym związanym $\mathrm{z}$ wdrażaniem do pracy. Wyniki własne nie są zatem zgodne z cytowanymi, co wskazuje na znaczne różnice w poziomie HR, które są wyznacznikiem indywidualnego stanu osobnika i interakcji tego stanu z konkretnym wpływem środowiska [Roelofs i in. 2016]. Najniższe wartości HR, odnotowane w grupie koni rekreacyjnych (grupa III), mogły być spowodowane faktem, że konie te są zobojętniałe na ciągle zmieniających się jeźdźców, a ponadto oprócz pracy w rekreacji mają zapewniony wielogodzinny ruch na świeżym powietrzu i kontakty społeczne, czego niestety często brakuje koniom sportowym.

Podwyższone wartości HR koni z grup I-II, czyli koni użytkowanych głównie sportowo, mogą być natomiast spowodowane ich nadmierną pobudliwością oraz ograniczoną ilością ruchu, co jak podaje wielu autorów, istotnie wpływa na 
poziom stresu [Rivera i in. 2002, Visser i in. 2002]. Rozkład wartości HR wszystkich koni przed wysiłkiem w poszczególnych grupach przedstawia rysunek 1.

Tabela 1. Statystyczna charakterystyka wartości HR grup koni badanych przed wysiłkiem

\begin{tabular}{|l|c|c|c|}
\hline \multirow{2}{*}{ HR } & \multicolumn{3}{|c|}{ Przed wysiłkiem } \\
\cline { 2 - 4 } & grupa I & grupa II & grupa III \\
\hline Średnia & $53,15 \mathrm{~A}$ & $61,82 \mathrm{~B}$ & $40,13 \mathrm{C}$ \\
Min. & 28 & 35 & 24 \\
Maks. & 79 & 79 & 69 \\
S & 7,37 & 3,72 & 5,57 \\
\hline
\end{tabular}

$\mathrm{A}, \mathrm{B}, \mathrm{C}$ - średnie oznaczone różnymi literami różnią się istotnie przy $\mathrm{P} \leq 0,01$

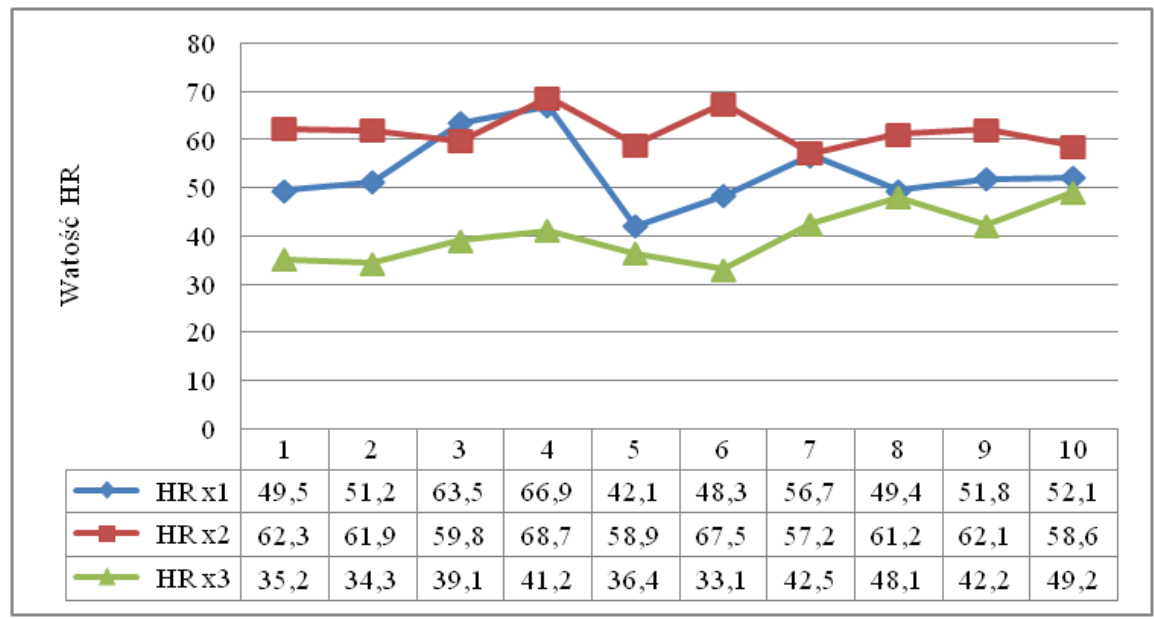

Rys. 1. Wartości HR koni przed wysiłkiem

$\mathrm{Z}$ danych zawartych w tabeli 2 i rysunku 2 wynika, że najwyższy wysiłkowy poziom HR wystąpił u koni zakwalifikowanych do grupy II, czyli dosiadanych przez 3-5 jeźdźców. Ta sytuacja była analogiczna do odnotowanej podczas badań przeprowadzonych przed wysiłkiem. Wspominana wartość oscylowała wokół 164,77 ud./min. Niestety, należy ją uznać za niepokojąco wysoką, gdyż ten poziom jest porównywalny z poziomem odnotowanym przez Becker-Birck $\mathrm{i}$ in. [2013] podczas treningu skokowego, czyli podczas znacznie większego wysiłku niż zastosowany w niniejszej pracy [Bartolomé i in. 2013]. Warto również podkreślić, że wskazana sytuacja nie może być uznana za przewidywalną, gdyż w grupie II znajdowały się głównie konie sportowe, które z założenia powinny mieć większą wydolność organizmu od koni rekreacyjnych [Burlikowska i in. 2015]. Można na tej podstawie sądzić, że właśnie dosiadanie tego samego konia przez 
kilku jeźdźców w największym stopniu powoduje wzrost pobudliwości emocjonalnej organizmu. Wydaje się również, że najniższa średnia, jaka wystąpiła w III grupie, czyli koni rekreacyjnych dosiadanych przez dużą liczbę jeźdźców, jeszcze raz podkreśla ich adaptację do określonych warunków pracy. Teorię nt. zobojętnienia koni rekreacyjnych na otaczające je środowisko podkreślają natomiast wyniki koni z grupy o dużej liczbie jeźdźców. Wyniki własne potwierdzają w tym miejscu sugestie zawarte w manuskrypcie opublikowanym przez Hemsworth i in. [2015].

Tabela 2. Statystyczna charakterystyka wartości HR grup koni badanych podczas wysiłku

\begin{tabular}{|l|c|c|c|}
\hline \multirow{2}{*}{ HR } & \multicolumn{3}{|c|}{ W trakcie wysiłku } \\
\cline { 2 - 4 } & grupa I & grupa II & grupa III \\
\hline Średnia & $87,97 \mathrm{AB}$ & $164,77 \mathrm{AC}$ & $76,78 \mathrm{BC}$ \\
Min. & 42 & 58 & 38 \\
Maks. & 145 & 209 & 145 \\
S & 17,22 & 5,89 & 12,8 \\
\hline
\end{tabular}

$\mathrm{A}, \mathrm{B}, \mathrm{C}$ - średnie oznaczone różnymi literami różnią się istotnie przy $\mathrm{P} \leq 0,01$

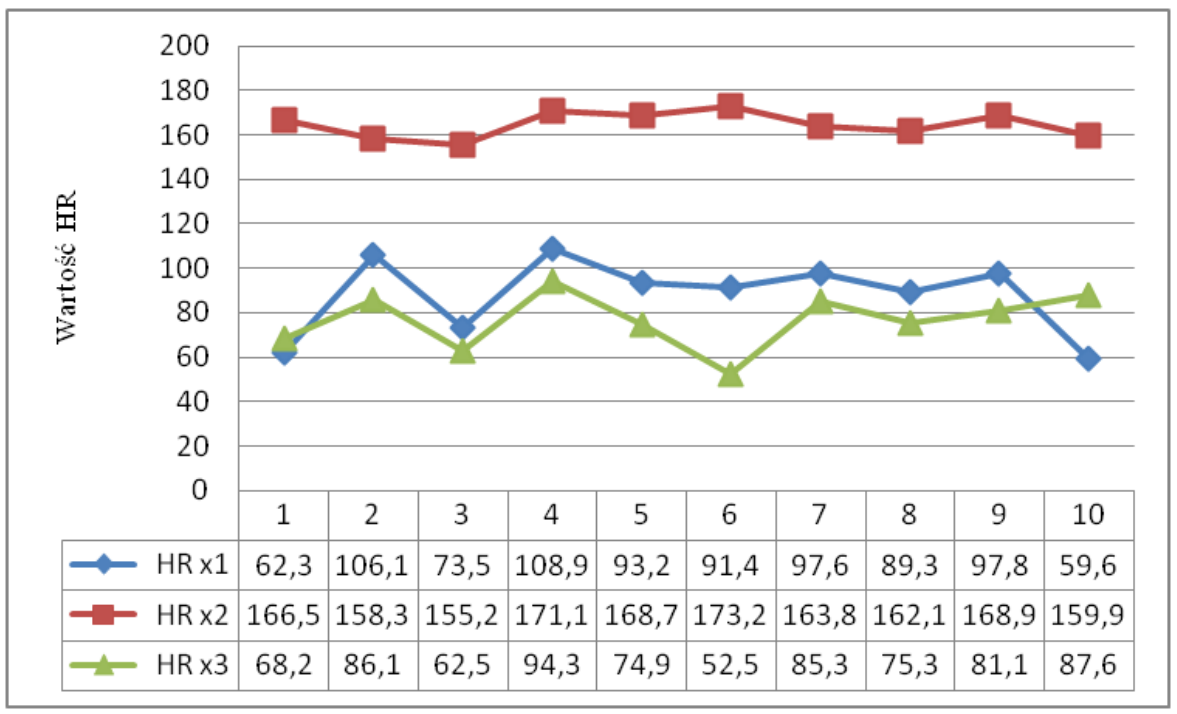

Rys. 2. Wartości HR koni podczas wysiłku

$\mathrm{Z}$ drugiej strony wspominamy fakt może być również spowodowany wyborem do tego typu użytkowania jedynie koni o określonych cechach psychicznych, które wiążą się z niskim poziomem pobudliwości emocjonalnej [Janczarek i Wilk 2017]. Na znaczący wpływ komponenty emocjonalnej w kształtowaniu parametrów pracy serca wskazują również badania przeprowadzone przez Kędzierskiego i in. [2012]. Uzyskane wyniki można zatem uznać za zgodne z cytowanymi. 
Wartości HR badanych koni, które odnotowano po wysiłku, zostały przedstawione w tabeli 3 i na rysunku 3. Po raz kolejny odnotowano analogiczne jak poprzednio różnice między średnimi. Najwyższy poziom HR odnotowano w grupie II (133,79 ud./min), a najniższy w grupie III (67,27 ud./min). artości podobne do

Tabela 3. Statystyczna charakterystyka wartości HR koni badanego po wysiłku

\begin{tabular}{|l|c|c|c|}
\hline \multirow{2}{*}{ HR } & \multicolumn{3}{|c|}{ Po wysiłku } \\
\cline { 2 - 4 } Średnia & grupa I & grupa II & grupa III \\
Min. & $90,06 \mathrm{~A}$ & $133,79 \mathrm{~B}$ & $67,27 \mathrm{C}$ \\
Maks. & 29 & 55 & 25 \\
S & 123 & 191 & 131 \\
& 11,62 & 3,72 & 12,5 \\
\hline
\end{tabular}

$\mathrm{A}, \mathrm{B}, \mathrm{C}$ - średnie oznaczone różnymi literami różnią się istotnie przy $\mathrm{P} \leq 0,01$

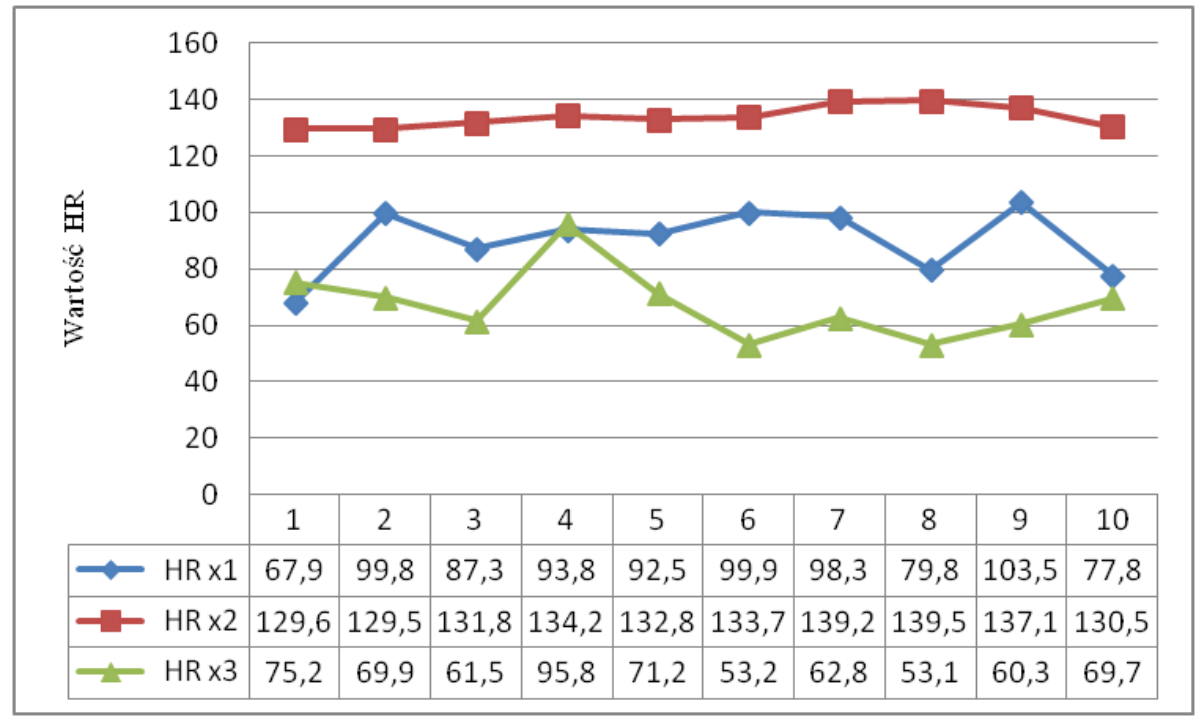

Rys. 3. Wartości HR koni po wysiłku

uzyskanych w grupie II przedstawił Pietrzak i in. [2004], badając młode konie półkrwi. Zawierały się one w zakresie od 132,2 do 136,2 ud./min i mimo tych wysokich poziomów zostały uznane za typowe dla młodych osobników podczas wykonywania nieznanych im zadań. O ile w przypadku młodych koni wysokie HR powysiłkowe można tłumaczyć brakiem doświadczenia, to u dorosłych koni sportowych takie zjawisko nie powinno występować [Schmidt i in. 2010]. Jak podaje Szarska [2007], u osobników dobrze wytrenowanych największy spadek HR notowany jest w pierwszych trzech minutach po zakończeniu wysiłku. $\mathrm{Na}$ 
zaobserwowany stan może mieć wpływ niewłaściwie prowadzony trening lub zbyt duże obciążenie fizyczne i psychiczne, które nakłada się na brak doświadczenia życiowego [Robson i in. 2003].

\section{Podsumowanie}

Uzyskane w niniejszej pracy wyniki wskazują na znaczące różnice w częstosci pracy serca koni dosiadanych przez różną liczbę jeźdźców. Okazuje się, że zarówno w trakcie czynności poprzedzających trening, podczas wysiłku i po wysiłku najniższe wartości wspomnianego parametru towarzyszą koniom dosiadanym przez dużą liczbę jeźdźców, a najwyższe koniom użytkowanym przez 3-5 osób. Te wyniki nie potwierdzają zatem postawionej w pracy hipotezy, gdyż mała liczba jeźdźców nie wiąże się z niską pobudliwością emocjonalną koni przez nich dosiadanych. Najprawdopodniej fakt ten jest spowodowany interakcją wielu czynników, a nie tylko wpływem jeźdźca lub jeźdźców.

\section{Bibliografia}

Albinson C., 2012. Koń. Poradnik miłośnika. Bellona, Warszawa, 72-74.

Bartolomé E., Sánchez M.J., Molina A., Schaefer A.L., Cervantes I., Valera M., 2013. Using eye temperature and heart rate for stress assessment in young horses competing in jumping competitions and its possible influence on sport performance. Animal 7(12), 2044-2053. https://doi.org/10.1017/S1751731113001626

Bartolomé E., Cockram M.S., 2016. Potential effects of stress on the performance of sport horses. J. Equine Vet. Sci. 40, 84-93. https://doi.org/10.1016/j.jevs.2016.01.016

Becker-Birck M., Schmidt A., Lasarzik J., Aurich J., Möstl E., Aurich C., 2013. Cortisol release and heart rate variability in sport horses participating in equestrian competitions. J. Vet. Beh. 8(2), 87-94. https://doi.org/10.1016/j.jveb.2012.05.002

Bürger U., Zietzschmann O., 2010. Konia kształtuje jeździec. Funkcje i rozwój mięśni konia wierzchowego. Wyd. Galaktyka, Łódź.

Burlikowska K., Bogusławska-Tryk M., Szymeczko R., Piotrowska A., 2015. Haematological and biochemical blood parameters in horses used for sport and recreation. J. Cent. Eur. Agric. 16(4), 370-382. https://doi.org/10.5513/JCEA01/16.4.1634

Burn C.C., Dennison T.L., Whay H.R., 2010. Relationships between behaviour and health in working horses, donkeys, and mules in developing countries. Appl. Anim. Behav. Sci. 126(3-4), 109-118. https://doi.org/10.1016/j.applanim.2010.06.007

Eilam E., Trop T., 2012. Environmental attitudes and environmental behavior - which is the horse and which is the cart? Sustainability 4(9), 2210-2246. https://doi.org/10.3390/su4092210

Goachet A.G., Varloud M., Philippeau C., Julliand V., 2010. Long-term effects of endurance training on total tract apparent digestibility, total mean retention time and faecal microbial ecosystem in competing Arabian horses. Equine Vet. J. 42, 387-392. https://doi.org/10.1111/j.20423306.2010.00188.x

Hall C., Huws N., White C., Taylor E., Owen H., McGreevy P., 2013. Assessment of ridden horse behavior. J. Vet. Behav. 8(2), 62-73. https://doi.org/10.1016/j.jveb.2012.05.005

Hall C., Kay R., Yarnell K., 2014. Assessing ridden horse behavior: Professional judgment and physiological measures. J. Vet. Behav. 9(1), 22-29. https://doi.org/10.1016/j.jveb.2013.09.005 
Hemsworth L.M., Jongman E., Coleman G.J., 2015. Recreational horse welfare: The relationships between recreational horse owner attributes and recreational horse welfare. Appl. Anim. Beh. Sci. 165, 1-16. https://doi.org/10.1016/j.applanim.2014.11.019

Ijichi C.L., Collins L.M., Elwood R.W., 2013. Evidence for the role of personality in stereotypy predisposition. Anim. Behav. 85(6), 1145-1151. https://doi.org/10.1016/j.anbehav.2013.03.033

Ikinger C., Spiller A., Kayser M., 2016. Factors influencing the attitude of equestrians towards sport horse welfare. Anim. Welf. 25(4), 411-422. https://doi.org/10.7120/09627286.25.4.411

Janczarek I., Kędzierski W., Stachurska A., Wilk I., 2016. Can releasing racehorses to paddocks be beneficial? Heart rate analysis-preliminary study. Ann. Anim. Sci. 16(1), 87-97. https://doi.org/10.1515/aoas-2015-0049

Janczarek I., Stachurska A., Kędzierski W., Wilk I., 2013. Responses of horses of various breeds to a sympathetic training method. J. Equine Vet. Sci. 33(10), 794-801. https://doi.org/ 10.1016/j.jevs.2012.12.014

Janczarek I., Wilk, I., 2017. Leisure riding horses: research topics versus the needs of stakeholders. Anim. Sci. J. 88(7), 953-958. https://doi.org/10.1111/asj.12800

Kaproń M., Strzelec K., Janczarek I., Kolstrung R., Pluta M., 1997. Zmienność wskaźników zaawansowania treningowego koni przygotowanych do rajdów długodystansowych - w zależności od ich rasy i rodzaju sprawdzianu. Zesz. Nauk. AR w Szczecinie, Zootechnika 177, 215-224.

Kędzierski W., Janczarek I., 2009. Sex - related effect of early training on stress in young trotters as expressed by heart rate. Anim. Sci. Pap. Rep. 27, 23-31.

Kędzierski W., Janczarek I., Stachurska A., 2012. Emotional response of naive Purebred Arabian colts and fillies to sympathetic and traditional training methods. J. Equine Vet. Sci. 32(11), 752-756. https://doi.org/10.1016/j.jevs.2012.03.002

Kirsty R., Andrew H., Meriel M.C., Catherine H., 2015. Cognitive differences in horses performing locomotor versus oral stereotypic behaviour. Appl. Anim. Behav. Sci. 168, 37-44. https://doi.org/10.1016/j.applanim.2015.04.015

Liou K., Ho S., Fildes J., Ooi S.Y., 2016. High intensity interval versus moderate intensity continuous training in patients with coronary artery disease: a meta-analysis of physiological and clinical parameters. Heart Lung Circ. 25(2), 166-174. https://doi.org/10.1016/j.hlc.2015.06.828

McBride S.D., Mills D.S., 2012. Psychological factors affecting equine performance. BMC Vet. Res. 8(1), 180

McGowan C.M., Hyytiäinen H.K., 2017. Muscular and neuromotor control and learning in the athletic horse. Comp. Exerc. Physiol. 13(3), 185-194. https://doi.org/10.3920/CEP170001

Mills D.S., McDonnell S.M., McDonnell S. (red.), 2005. The domestic horse: the origins, development and management of its behaviour. Cambridge University Press.

Pietrzak S., Strzelec K., Bocian K., Lewczuk D., 2004. Współzależność jakości stylu wolnych skoków i wartości tętna wysiłkowego u młodych koni małopolskich. Zesz. Nauk. Prz. Hod. 72(5), 17-23.

Rivera F., Benjamin S., Nielson B., Shelle J., Zanella A.J., 2002. Behavioural and psychological responses of horses to initial training: the comparison between pasture versus stalled horses. Appl. Anim. Behav. Sci. 78, 235-252.

Robson P.J., Alston T.D., Myburgh K.H., 2003. Prolonged suppression of the innate immune system in the horse following an $80 \mathrm{~km}$ endurance race. Equine Vet. J. 35, 133-137. https://doi.org/10.2746/042516403776114144

Roelofs S., Boleij H., Nordquist R.E., Staay F.J. van der, 2016. Making decisions under ambiguity: judgment bias tasks for assessing emotional state in animals. Front. Behav. Neurosci. 10, 119 https://doi.org/10.3389/fnbeh.2016.00119

Rollin B., 2011. Putting the horse before Descartes: My life's work on behalf of animals. Temple University Press.

Sarrafchi A., Blokhuis H. J., 2013. Equine stereotypic behaviors: causation, occurrence, and prevention. J. Vet. Behav. 8(5), 386-394. https://doi.org/10.1016/j.jveb.2013.04.068 
Schmidt A., Aurich J., Möstl E., Müller J., Aurich C., 2010. Changes in cortisol release and heart rate variability during the initial training of three-year-old sport Horses. Horm. Behav. 58, 628-636. https://doi.org/10.1016/j.yhbeh.2010.06.011

Stachurska A., Janczarek I., Wilk I., Kędzierski W., 2015. Does music influence emotional state in race horses? J. Equine Vet. Sci. 35(8), 650-656. https://doi.org/10.1016/j.jevs.2015.06.008

Szarska E., 2007. Konne rajdy długodystansowe. Agencja Reklamowa „Crex”, Warszawa, 64-73.

Tsuzuki N., Sasaki N., Kusano K., Endo Y., Torisu S., 2016. Oxidative stress markers in Thoroughbred horses after castration surgery under inhalation anesthesia. J. Equine Sci. 27(2), 77-79. https://doi.org/10.1294/jes.27.77

Valenchon M., Lévy F., Moussu C., Lansade L., 2017. Stress affects instrumental learning based on positive or negative reinforcement in interaction with personality in domestic horses. PloS One 12(5). https:doi.org/10.1371/journal.pone.0170783

Valera M., Bartolomé E., Sánchez M.J., Molina A., Cook N., Schaefer A.L., 2012. Changes in eye temperature and stress assessment in horses during show jumping competitions. J. Equine Vet. Sci. 32(12), 827-830. https://doi.org/10.1016/j.jevs.2012.03.005

Vincze A., Szabo C., Veres S., Uto D., Hevesi A.T., 2017. Fitness improvement of show jumping horses with deep water treadmill training. Vet. Med-Czech 62(4), 192-199. https://doi.org/ 10.17221/135/2016-VETMED

Visser E.K., Van Wijk-Jansen E.E., 2012. Diversity in horse enthusiasts with respect to horse welfare: An explorative study. J. Vet. Behav. 7(5), 295-304. https://doi.org/10.1016/j.jveb.2011.10.007

Visser E.K., Reenen C.G. van, Werf J.T. van der, Schilder M.B., Knaap J.H., Barneveld A., Blokhuis H.J., 2002. Heart rate and heart rate variability during a novel object test and a handing test in young horses. Physiol. Behav. 76, 289-296. https://doi.org/10.1016/S00319384(02)00698-4

Young T., Creighton E., Smith T., Hosie C., 2012. A novel scale of behavioural indicators of stress for use with domestic horses. Appl. Anim. Behav. Sci. 140(1-2), 33-43. https://doi.org/ 10.1016/j.applanim.2012.05.008 